United States

Department of the Interior

Geological Survey

\title{
HYDROCARBON RESOURCE REPORT FOR PROPOSED OCS LEASE SALE 88: \\ SOUTHEASTERN ALASKA, NORTHERN GULF OF ALASKA, \\ COOK INLET, AND SHELIKOF STRAIT, ALASKA
}

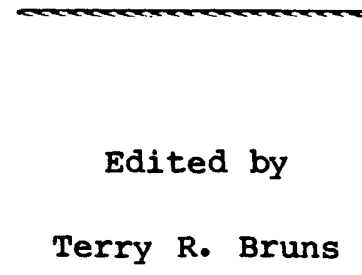

Terry R. Bruns

OPEN-FILE REPORT

$82-928$

\footnotetext{
This report is preliminary and has

not been reviewed for conformity with U.S. Geological Survey editorial

standards and stratigraphic nomenclature.

\begin{abstract}
Any use of trade names is for descriptive purposes only and
\end{abstract} does not imply endorsement by the U.S. Geological Survey.
}

Menlo Park, California 


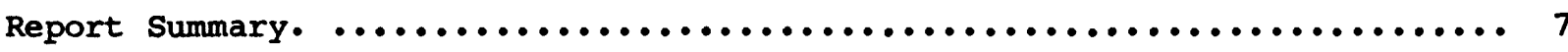

Introduction.................................................

\section{Chapter I}

Geology, structure, and petroleum potential of the southeastern Alaska and northern Gulf of Alaska continental margins, by Terry R. Bruns and George Plafker.

Introduction ................................................11

Geologic summary............................................... 11

Onshore........................................ 11

Offshore....................................... 13

Geologic history.............................................. 18

Offshore structure............................................19

Southeastern Alaska.............................. 19

Yakutat segment.................................. 23

Yakataga segment................................ 30

Middleton segment............................... 36

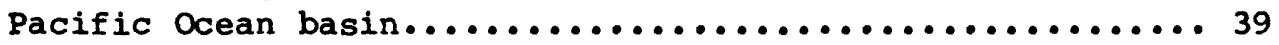

Petroleum geology ............................................ 40

Introduction...................................4 40

Source and reservoir rock characteristics.............40

Thermal maturity...............................43

Thermal analysis of dredged rocks...................43

Calculated thermal maturity of Paleogene rocks.........446

Reservoir rocks.................................46

structural and stratigraphic traps.................. 48

Petroleum potential: Discussion.............................. 50

Illustrations and Tables

Figure 1. Figure 2 . Figure 3. Figure 4. Figure 5.

Figure 6 .

Figure 7. Figure 8.

Figure 9. Figure 10.

Figure 11. Figure 12.

Figure 13.
Index map for ocs sale no. $88 \ldots \ldots \ldots \ldots \ldots \ldots \ldots \ldots \ldots \ldots \ldots \ldots . \ldots \ldots \ldots$ Index map of the northern Gulf of Alaska............... 12 Index map showing locations of dredged rock samples...... 15 Generalized geologic map of the Yakutat segment......... 16 Diagrammatic continental slope section showing dredge haul sample intervals........................... 17 Simplified geologic and tectonic setting of the northern Gulf of Alaska................................ 20 Tracklines for multichannel seismic data............. 21 structure trends and line drawings of seismic data, southeastern Alaska segment....................... 22 Index map of Yakutat segment........................ 24 Structure contours at the base of Paleogene strata, Yakutat segment................................. 25 Isopach map of Paleogene strata, Yakutat segment........ 26 Structure contours at the base of Neogene strata, Yakutat segment........................................ 27 Seismic sections 906 and 403 , Yakutat segment.......... 28 
Figure 14. Seismic sections 903 and 967 , Yakutat segment.......... 29

Figure 15a. Index map of Yakataga segment...................... 31

Figure 15b. Explanation for figures $15 \mathrm{a}$ and $16 \ldots \ldots \ldots \ldots$

Figure 16. Yakataga segment structure contours.................. 33

Figure 17. Seismic sections 406 and 409 , Yakataga segment.......... 34

Figure 18. Seismic sections 412 and 922 , Yakataga segment......... 35

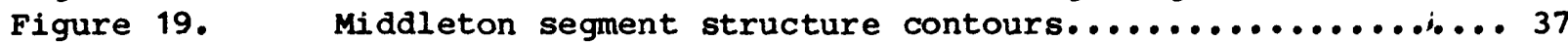

Figure 20. Seismic sections 421 and 424 , Middleton segment......... 38

Table 1. Stratigraphic summary of rocks dredged from the continental slope, Yakutat segment................... 14

Table 2.

Table 3.

Wells drilled in the Yakataga segment................. 41

Organic carbon and visual kerogen assessment of

dredged rocks..................................442

Table 4.

Table 5 .

Vitrinite reflectance summary of dredged rocks.........444

Organic carbon content and Rock-Eval pyrolysis data for

selected dredged samples.........................4 45

Table 6 .

Sandstone reservoir characteristics of dredged rocks..... 47

\section{Chapter II}

Geology, structure and petroleum potential

of the lower Cook Inlet-Shelikof Strait region;

by Michael A. Fisher and Leslie B. Magoon.

Introduction. ............................................. 53

General geology .......................................... 53

offshore structure.........................................6 60

Petroleum geology .........................................60

oil fields................................... 64

Gas fields................................... 65

Hyarocarbon potential of the sale area...............65

\section{Illustrations}

Figure 1.

Figure 2 .

Figure 3.

Figure 4 .

Figure 5 .

Figure 6 .

Figure 7.

Figure 8 .
Geography of the Cook Inlet-Shelikof strait Area........ 54 Onshore geology of areas adjacent to cook Inlet and Shelikof strait.............................. 56 Explanation of symbols and abbreviations........... 57 Stratigraphic names and thickness of rock units........ 58 Subsurface geology on cross sections $A-A^{\prime}, B-B^{\prime}$, and $C-C^{\prime}, 61$ Structure contours on base of cenozoic rocks...........62 Contours of free-air gravity.....................6. 63 Offshore tracts based in previous sales.............67 


\section{Chapter III}

Resource assessment, by Robert H. McMullin

Resource assessment......................................68

Tables

Table 1. Estimates of total undiscovered oil and gas, Cook Inlet... 69

Table 2. Estimates of total undiscovered oil and gas,

Shelikof Straits shallow $(0-200 \mathrm{~m}) \ldots \ldots \ldots \ldots \ldots \ldots \ldots . \ldots . \ldots 70$

Table 3. Estimates of undiscovered oil and gas eastern Gulf of

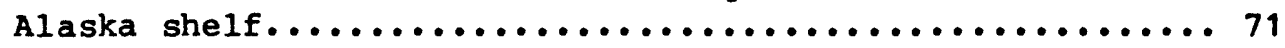

Table 4. Estimates of undiscovered oil and gas, eastern Gulf of

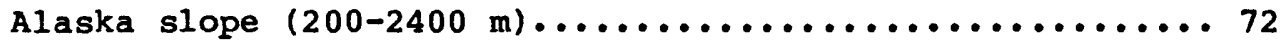

\section{Chapter IV}

Northern Gulf of Alaska environmental geology,

by Paul R. Carlson and William C. Schwab.

Introduction. ..........................................

Southeastern Alaska segment. ................................. 73

Yakutat segment............................................ 76

Surface and near-surface faults................... 76

Seafloor instability............................ 78

Gas-charged sediment.......................... 78

Submarine slides............................... 79

Buried channels................................ 80

Yakataga and Middleton segments............................... 81

Surface and near-surface faults.................... 81

Submarine slides and slumps........................ 85

\section{Illustrations}

Figure 1. Sketch map of southeastern Alaska, showing faults and tracklines.................................... 74

Figure 2. Location map of seafloor geologic hazards, Yakutat

Figure 3. segment.................................. 77

Figure 4.

Seafloor hazards of the Middleton segment............. 82

Seafloor hazards of the Yakataga segment.............. 83

\section{Chapter V}

Geotechnical investigations related to geologic hazards: northern Gulf of Alaska, by Homa J. Lee and William C. Schwab.

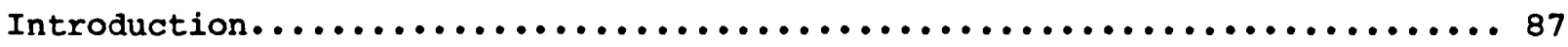

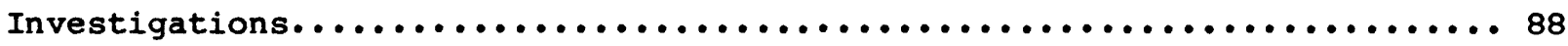

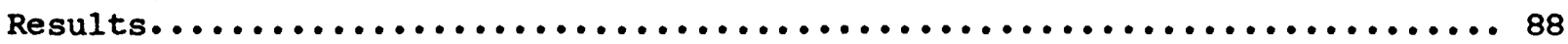




\section{Illustrations and Tables}

Figure 1. Study area and geographical features of the northern Gulf of Alaska................................ 92

Figure 2. Map of stratigraphic units between Yakutat Bay and Montague Island.............................. 93

Figure 3. In place vane shear strength profiles............... 94

Table 1. Locations of in-place vane shear tests............... 91

\section{Chapter VI}

Lower Cook Inlet environmental geology, by Monty A. Hampton.

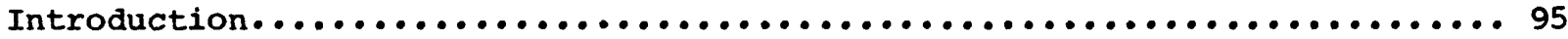

Seismicity .................................................. 95

Volcanism.....................................................97

Sedimentary processes and deposits.............................. 97

\section{Illustrations}

Figure 1.

Bathymetry of lower cook Inlet..................... 100

Figure 2.

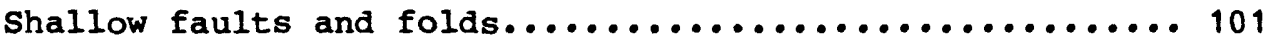

Figure 3.

Thickness of unconsolidated sediment................ 102

Figure $4 a$.

Distribution of surficial sediment types............. 103

Figure $4 \mathrm{~b}$.

Definition of sediment types......................104

Figure 5 .

Distribution of bedforms on the sea floor............. 105

\section{Chapter VII}

Shelikof Strait environmental geology, by Monty A. Hampton.

Introduction. .............................................106

Seismicity and tectonism..................................106

Volcanism...................................................107

Sedimentary processes and deposits............................. 107

\section{Illustrations}

Figure 1. Figure 2 .

Figure 3.

Figure 4.

Figure 5 .

Figure 6 .
Bathymetry of Shelikof strait..................... 109 Shallow structures in shelikof strait............... 110 Thickness of near surface sedimentary deposits.........111 Main grain size of seafloor sediment................. 112 Locations of anomalous acoustic returns..............113 Locations of craters.............................. 114 


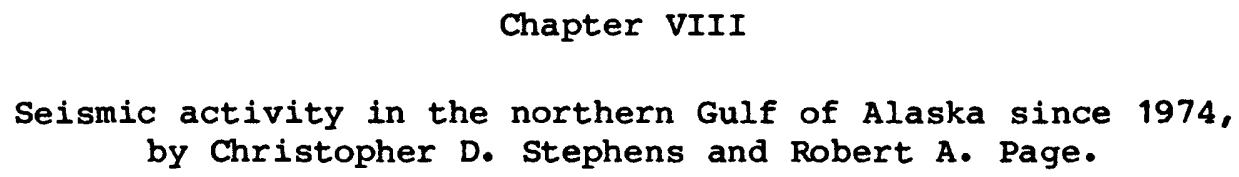

References cited.......................................... 122 


\section{SUMMARY}

This report is a summary of the geology, structure, petroleum potential, and seafloor geologic hazards of the study area for proposed outer continental Shelf lease sale no. 88. This area includes the continental margins of southeastern Alaska and the northern Gulf of Alaska, the Pacific Ocean basin adjacent to these areas, and lower Cook Inlet and Shelikof Strait. Five prior sales have been held in the areas covered by the study area. Eighteen wells drilled since these lease sales have discovered no commercial oil or gas. This report summarizes and augments resource reports prepared for the earlier sales, and emphasizes new data and interpretations that have become available since publication of the earlier reports.

Although drilling results in the northern Gulf of Alaska have so far been disappointing, there are still reasons for considerable optimism for the eventual discovery of commercial hydrocarbon accumulations. The major positive consideration is that studies of dredge samples and onshore oil seeps have shown that oil is being generated in an organic rich, lower to middle Eocene sedimentary sequence. Organic rich samples that may be potential source rocks are present throughout the entire Eocene-Oligocene sedimentary sequence, a sequence that is from 2 to $4 \mathrm{~km}$ thick and underlies the continental shelf and slope from Fairweather Ground to Kayak Island, an area of about $30,000 \mathrm{~km}^{2}$. Most of the dredge and onshore samples are thermally immature to marginally mature, but rocks similar to those sampled should be more mature beneath the continental shelf. The Eocene and Oligocene organic rich sedimentary rocks are not known to be present beneath the southeastern Alaska or Middleton segments of the continental shelf and slope, or from strata in the adjacent Pacific Ocean basin. These areas likely have poor resource potential.

Numerous potential traps are present throughout the continental margin of the northern Gulf of Alaska, particularly in large anticlinal folds in the southeastern Alaska segment (Dixon Entrance to Cross Sound), the Yakataga segment (ICY Bay to Kayak Island), and the Middleton segment (Kayak Island to Montague Island). The Yakutat segment (Cross Sound to Icy Bay) lacks major anticlinal folds like the folds to the west, although one large, gentle fold is present. Additional traps in this segment are likely to be subtle.

Major negative factors for the eventual discovery of commercial hydrocarbons in the Gulf of Alaska include the negligible source and reservoir rock potential of the thick late Cenozoic strata, the lack of major traps in the Eocene-Oligocene strata of the Yakutat segment, the deep burial of the Eocene-Oligocene strata beneath the Yakataga segment, and the generally poor reservoir rock potential throughout the Cenozoic sedimentary section.

Drilling in the northern Gulf of Alaska has tested the upper Cenozoic strata, but so far has not adequately tested the Eocene-Oligocene strata. The primary exploration strategy for the Gulf of Alaska is now the search for Eocene-Oligocene strata in the Yakutat and Yakataga segments. Discovery of economic petroleum is largely dependant on finding these strata in favorable traps, at drillable depths, and with adequate reservoir rocks.

Geologic hazards in the northern Gulf of Alaska include high seismicity and the associated risk of seafloor displacement due to faulting or regional 
warping. Numerous faults are present at or near the seafloor throughout the Gulf of Alaska study area. The historical seismicity record also indicates that at least part of the study area is a seismic gap, the Yakataga seismic gap, and is particularly susceptible to a great earthquake (magnitude greater than or equal to 7.4). Large areas of the seafloor are covered by thick, unstable sediment, and are subject to slumping and sediment mass movement. These sediments are particularly susceptable to slumping due to cyclic loading by either earthquakes or storm waves. Additional potential hazards include near-surface gas charged sediment, large scale erosion and deposition of sediment due to currents, buried channels, and tsunamis.

Drilling in the lower cook Inlet has also been disappointing; however, no drilling has yet occurred in Shelikof strait. Most of the attractive structures have been leased already, and mainly subtle traps remain to be leased in sale no. 88. Thick Mesozoic rocks beneath lower Cook Inlet and Shelikof strait probably contain potential source rocks. Reservoir rocks are mainly of Cenozoic age. However, the Cenozoic section is thin in the region of lower cook Inlet and Shelikof strait.

Geologic hazards in the lower Cook Inlet-Shelikof Strait region include high seismicity, and resultant ground shaking, surface faulting, surface warping, ground failure, and tsunamis. Active volcanoes create a danger of explosive volcanism, lava flows, ash falls, and nuee ardentes or lahars, especially in coastline areas and near Mt. Augustine. Thick sediment deposits may undergo failure, but do not appear to pose unusual geotechnical problems. Gas-charge sediment may be locally present in the unconsolidated sediment, as may areas of sediment venting due to liquifaction. Tidal currents in lower cook Inlet can create problems associated with scour or movement of large bedforms; these problems are not a significant concern in Shelikof strait. 


\section{INTRODUCTION}

This report summarizes data concerning the study area for Outer Continental Shelf lease sale no. 88. The study area consists of the continental margins of southeastern Alaska from Dixon Entrance to Cross Sound and the northern Gulf of Alaska from Cross Sound to Montague Island, the Pacific Ocean basin that is contiguous to these two areas, and cook, Inlet and Shelikof Strait (fig. 1).

Five lease sales have been held in areas under consideration for lease sale no. 88. These sales include three in the Gulf of Alaska: sale 39 in 1976, sale 55 in 1980, and a reoffering sale in 1981. Ten offshore wells were drilled on tracts leased during sale 39, with no discoveries of commercial oil or gas. None of the tracts leased during sale 55 or the reoffering sale have been drilled. Two sales have been held in the cook Inlet-Shelikof strait area, sale CI in 1977, and sale 60 in 1981. Eight subsequent exploratory wells drilled on these tracts have found no discoveries of commercial oil or gas.

Prenomination reports were prepared for these earlier sales: for the northern Gulf of Alaska, see Plafker and others $(1975,1978)$ and for Cook Inlet and Shelikof Strait, see Magoon and others (1975, 1976, 1979). The present report summarizes and augments these earlier reports. The major emphasis of this report is on new data and interpretations that have become available since publication of earlier reports, and on data from areas not included in prior lease sales.

This report consists of the seven chapters listed below.

Chapter I. Geology, structure, and petroleum potential of the southeastern Alaska and northern Gulf of Alaska continental margins: by Terry R. Bruns and George Plafker.

Chapter II. Geology, structure and petroleum potential of the Cook InletShelikof Strait region: by Michael A. Fisher and Leslie B. Magoon.

Chapter III. Resource assessment: by Robert H. McMullin.

Chapter IV. Northern Gulf of Alaska environmental geology: by Paul. R. Carlson and William C. Schwab.

Chapter v. Geotechnical investigations related to geologic hazards: northern Gulf of Alaska: by Homa J. Lee and William C. Schwab.

Chapter VI. Lower Cook Inlet environmental geology: by Monty A. Hampton.

Chapter VII. Shelikof Strait environmental geology: by Monty A. Hampton.

Chapter VIII. Seismic activity in the northern Gulf of Alaska since 1974: by Christopher D. Stephens and Robert A. Page. 


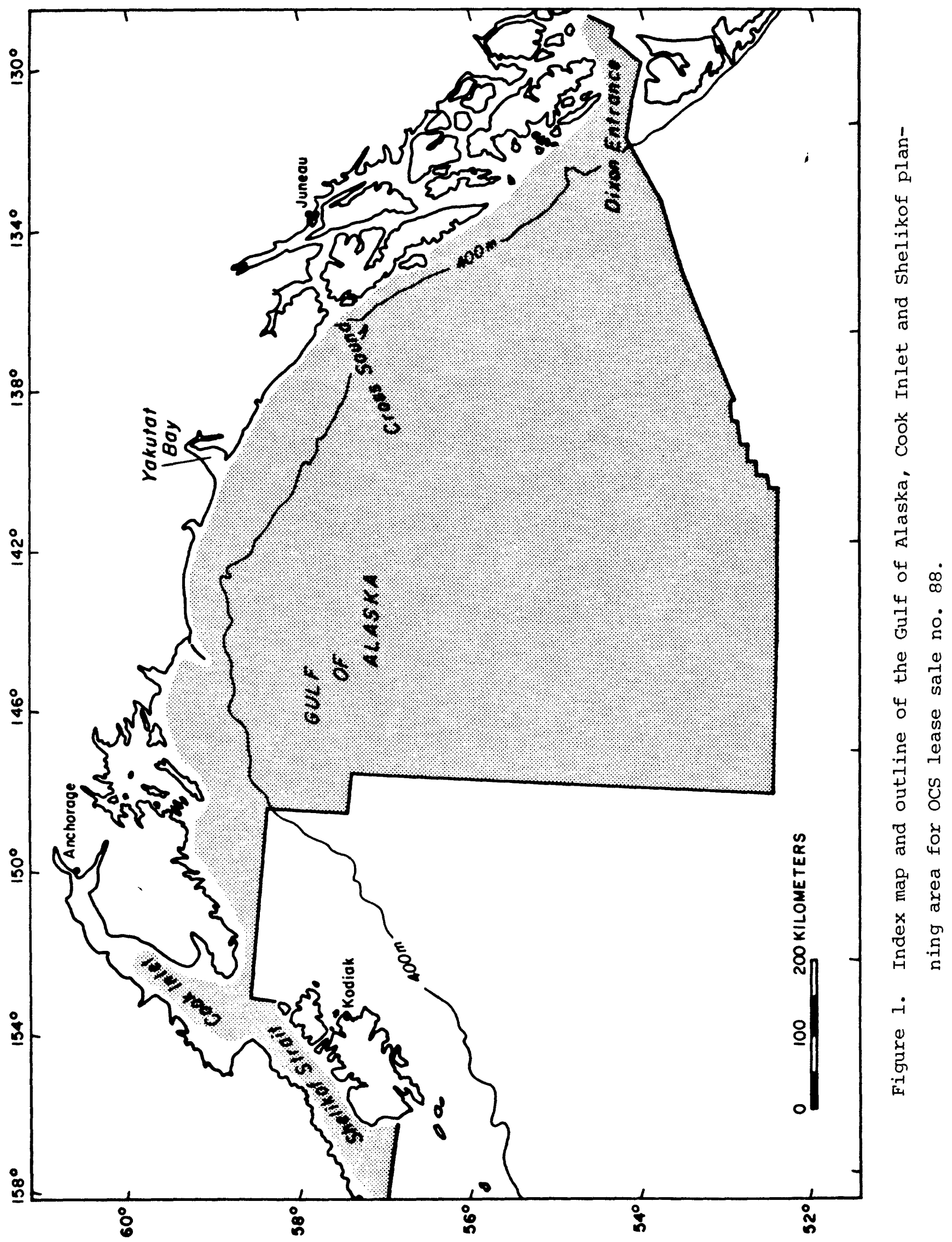




\section{CHAPTER I}

GEOLOGY, STRUCTURE, AND PETROLEUM POTENTIAL

OF THE SOUTHEASTERN ALASKA NORTHERN GULF OF ALASKA CONTINENTAL MARGINS

by

Terry R. Bruns and George Plafker

\section{INTRODUCTION}

For convenience of discussion of the proposed sale area in the Gulf of Alaska, we have divided the area into four geologically or physiographically distinctive continental margin segments, each of which includes the continental shelf, slope, and base of slope for the respective segment. From east to west, the segments are the southeastern Alaska segment from Dixon Entrance to Cross Sound, the Yakutat segment from Cross Sound to Icy Bay, the Yakataga segment from Icy Bay to Kayak Island, and the Middleton segment from Kayak Island to Montague Island (fig. 2). The sections on geology and geologic history will consider the entire Gulf of Alaska. The sections about structural framework, and petroleum geology will be written on a segment by segment basis.

\section{GEOLOGIC SUMMARY}

Onshore

Rocks of Mesozoic and older age border onshore Tertiary rocks in the high Chugach and St. Elias mountains on the north, and form the seaward band of rocks exposed on the islands of southeast Alaska. These rocks are highly deformed, locally metamorphosed sedimentary and volcanic rocks, and they are commonly intruded by igneous plutons (Plafker, 1971; Plafker and others, 1975, 1978a). The pre-Tertiary rocks are considered to have no potential for petroleum and will not be considered further.

The onshore Gulf of Alaska Tertiary province, between Cross Sound and Montague Island, is a compound continental margin basin made up almost entirely of terrigineous clastic rocks with minor coal. Bedded Cenozoic rocks onshore consist of both marine and non-marine units with a cumulative postPaleocene thickness of at least $15 \mathrm{~km}$. These rocks are broadly divisible into three subdivisions, described below, that correspond to major changes in the tectonic and depositional environment of the basin. 1. An early Tertiary sequence, Paleocene through early Oligocene age, includes the Orca Group, and the Kushataka, Kulthieth, and Tokun Formations. Rocks in this sequence are characteristically hard, dense, and variably deformed and faulted. The rocks are composed of deep-sea fan deposits and associated volcanic rocks of Paleocene age, and continental to shallow marine coal-bearing clastic rocks of Eocene to early oligocene age. 2. A middle Tertiary sequence, middle Oligocene through early Miocene age, includes the Katalla, Poul Creek, and Cenotaph Formations, composed primarily of mudstone and siltstone. 3. A late Tertiary through Holocene sequence includes the Yakataga, Redwood, and Topsy Formations. These strata are composed of mudstone, muddy sandstone and conglomeratic sandy mudstone, and are classed as marine diamictite characterized by abundant glacial detritus (Plafker, 1971; Plafker and 


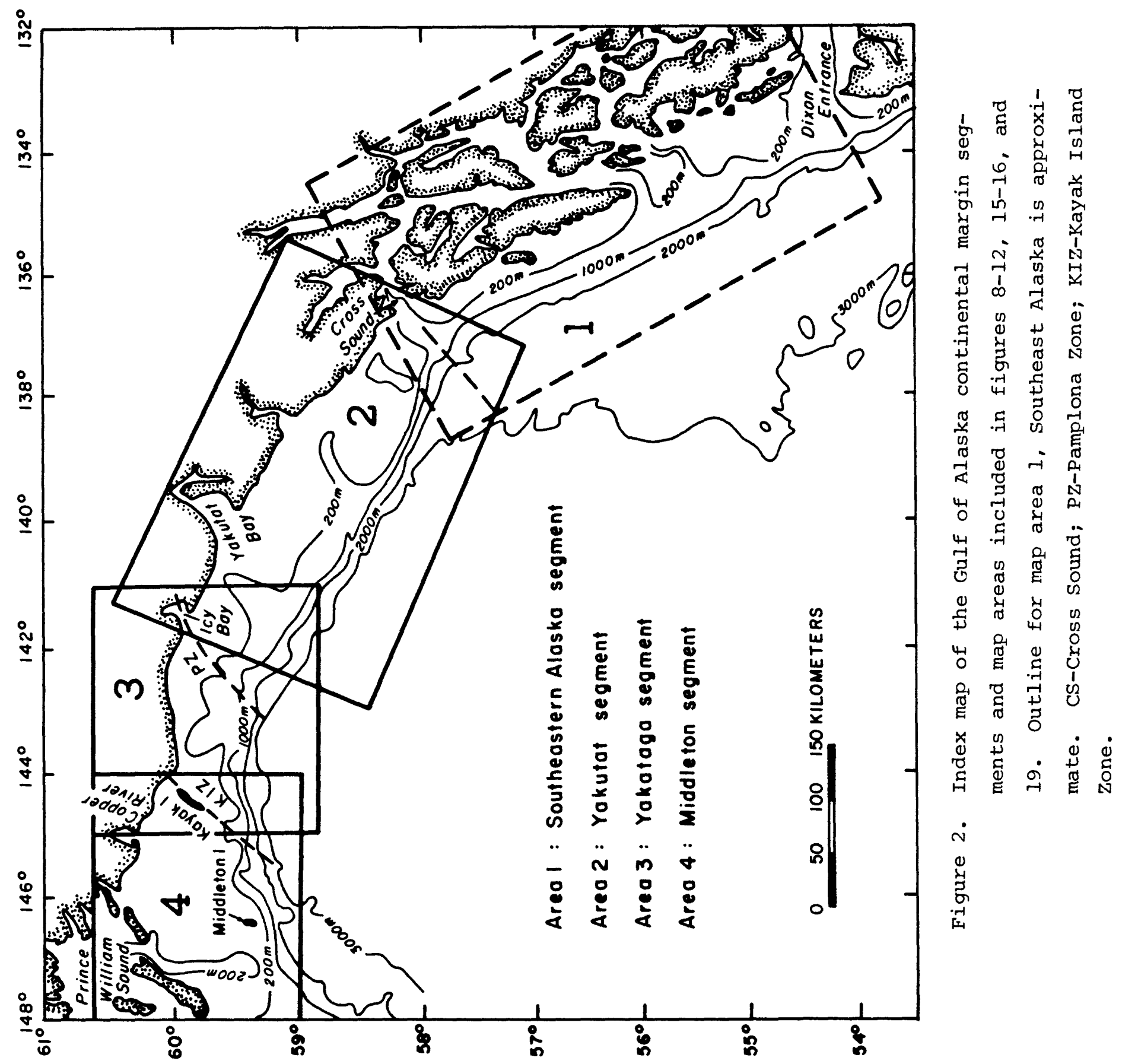


Addicott, 1976; Plafker and others, 1975, 1978a; Winkler, 1976).

General geologic features of the onshore Tertiary basin, including stratigraphy and structure, a correlation chart of stratigraphic units in the basin, and the approximate thickness and inferred correlations of selected surface and well sections have been summarized in prior prenomi nation reports (Plafker and others, 1975, 1978a) and publications (Plafker, 1971, 1974; Plafker and Addicott, 1976; Winkler, 1976; and winkler and others, 1981) and will not be repeated here.

\section{Of fshore}

The geology of the southeastern Alaska segment can be inferred only from seismic reflection data. Acoustic basement is near the surface over much of the shelf, and rocks forming the acoustic basement are probably similar to Paleozoic and Mesozoic rocks exposed in the nearby southeastern Alaska islands. A sedimentary sequence about $2 \mathrm{~km}$ or more thick is present locally beneath the outer shelf, and beneath the continental slope and the base of the slope. These strata are probably of Miocene and younger age, based on a correlation of seismic data to the rocks sampled in DSDP hole 178 near Kodiak Island (von Huene and others, 1979; Bruns, unpublished data) and on the age of the underlying oceanic crust as inferred from magnetic anomalies (Naugler and wageman, 1973; Taylor and O'Neil1, 1974).

Mesozoic through Pliocene age rocks underlie the continental slope of the Yakutat segment, and have recently been sampled by dredging (fig. 3-5; Plafker and others, 1978c, 1979, 1980). These rocks are described in Table 1. The rocks can be generalized in much the same way as the onshore rocks from oldest to youngest as follows (unit designations are from Table 1 and Plafker and others, 1980). 1. An inferred Late Cretaceous sequence consisting of hard graywacke, argillite, and possibly intrusive rocks (Unit $A$ ) is present on the continental slope off Fairweather Ground, and probably underlies much of Fairweather Ground. 2. A lower Tertiary sequence of Paleocene through oligocene age is present along parts of the continental slope from Fairweather Ground to about Pamplona Spur. This sequence consists of upper Paleocene (?) to lower Eocene (?) sandstone, conglomerate, and shale (Unit B), lower Eocene basalt flows and pyroclastic rocks (Unit $C$ ), early to middle Eocene sandstone, conglomerate, siltstone, and shale (Unit D), and upper Eocene and lower Oligocene(?) shale, tuffaceous shale, siltstone and sandstone (Unit E). 3. A middle Tertiary sequence consisting of upper Oligocene siltstone (Unit F) crops out locally along the upper slope. 4. A middle Miocene(?) and younger clastic sedimentary sequence (Unit $G$ ) is present along the upper slope, and is equivalent to the onshore Yakataga Formation. Seismic reflection data show that the Cenozoic rocks underlie much of the continental shelf and slope of the Yakutat and Yakataga segments.

The Paleogene sedimentary strata (Units $B$, and $D$ through $F$ ) are probably continentally derived, with younger rocks deposited in progressively shallower water. These rocks differ strikingly in lithology from coeval rocks either exposed in outcrop onshore or penetrated in exploratory wells onshore or offshore (Plafker and others, 1980).

The rocks of the Yakataga and Middleton segments have not been extensively sampled by dredging. Dredge data, well data, and seismic 
Table 1. Stratigraphic summary of rocks dredged from the continental slope of the Yakutat segment, Northern Gulf of Mlaska (from Plafker and others, 1980)

Unit $\frac{\text { Age }}{\text { Late Cretaceous }}$
Late Paleocene (?)
to early Eocene (?)

C Early Eocene

D Early and midale Eocene

$\mathbf{E}$

Early Eocene

to late Eocene, and possible early Oligocene. younger

\section{Lithology and Comments}

Hard graywacke, argillite, and possible intrusive rocks.

Calcareous feldspatholithic sandstone and conglomerate interbedded with hard carbonaceous and organic-rich shale or siltstone. Also includes subordinate anygdaloidal basaltic flow and pyroclastic rocks and diabase dike (?) rocks.

Dominantly basaltic flow and pyroclastic rocks with subordinate associated clastic marine sedimentary rocks. Most basalts are anygdaloidal; Plagioclase phenocrysts are common, and serpentinized ollvine phynocrysts are locally present. Textures range from glassy to diabasic.

Interbedded feldspatholithic sandstone, siltstone, organic rich shale, calcareous and concretionary shale, tuffaceous shale, ninor pebbly mudstone, tuff, volcaniclastic and bioclastic sandstone, and basalt. Unit contains a diverse and abundant nicrobiota including coccoliths, foraminifers, siliceous nicrofossils, polynomorphs, and organisms characteristic of shallow-water tropical carbonate reefs, such as algea, coral, bryozoans, and echinolds.

Organic rich shale, calcareous shale, tuffaceous shale, micaceous siltstone, and feldspatholithic calcite-matrix sandstone. Shale is commonly laminated and organic rich. Sequence contains a rich biota of microfossils, including coccoliths, foraminifers, and palynomorphs.

Silty shale with abundant mica and a rich diatom and silicoflagellate assembledge. In contrast to underlying strata, calcareous microfossils are absent and shale is relatively low in organic carbon content. Correlative in age with the onshore marine Poul Creek Formation, but lacks the characteristic poul Creek glauconite, mafic aquagene tuff and flow rocks, and foraminifers.

Marine mudstone, siltstone, sandstone, conglomerate, and conglomeratic sandy mudstone or diamictite. Ice rafted dropstones common. Correlative with the Yakataga Formation. See 'Plafker and Addicott (1976) for detalled study.
Bstimated

Maximum Thickness (m) Where Dredged

unknowm

900

1300

2100 


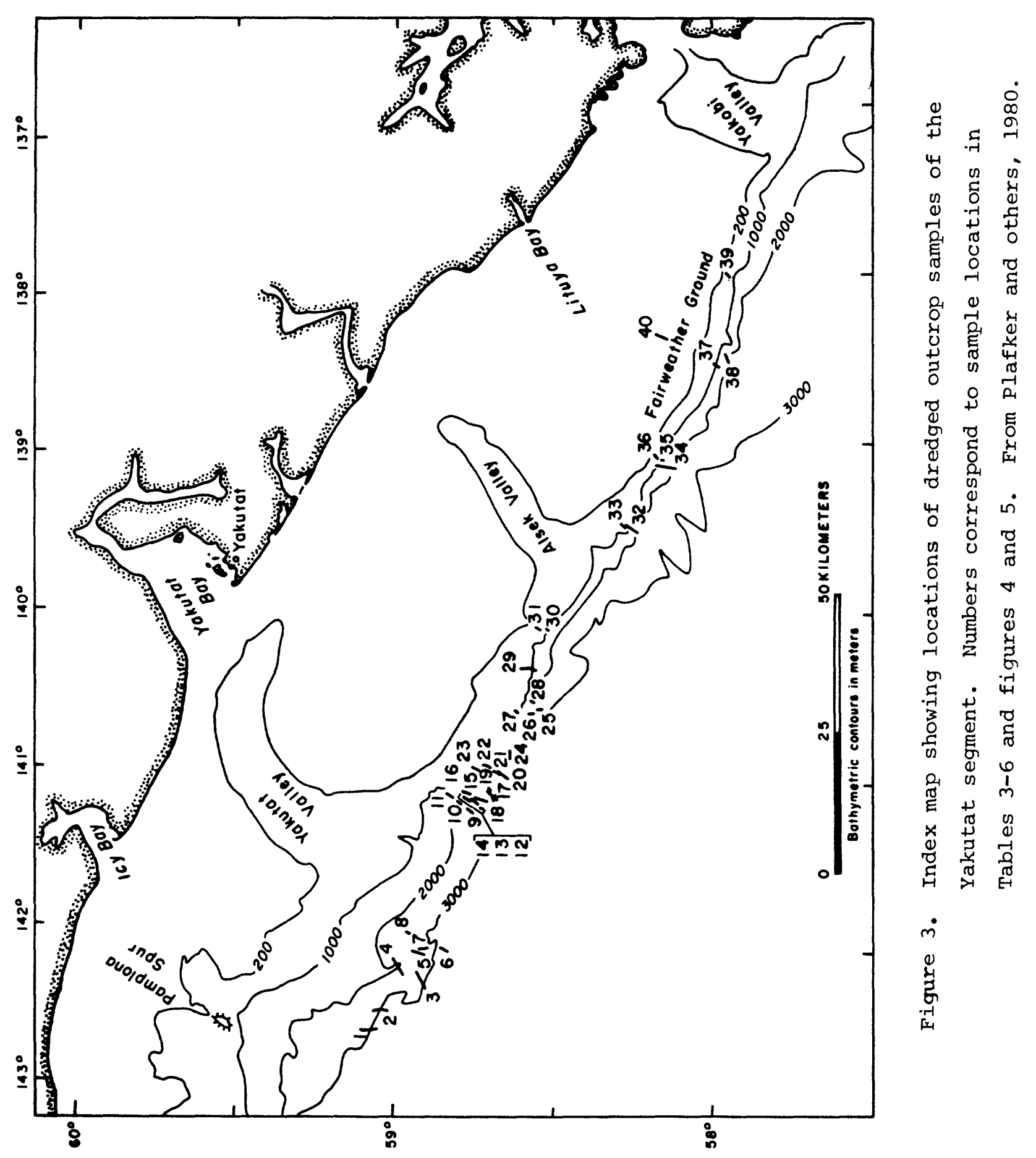




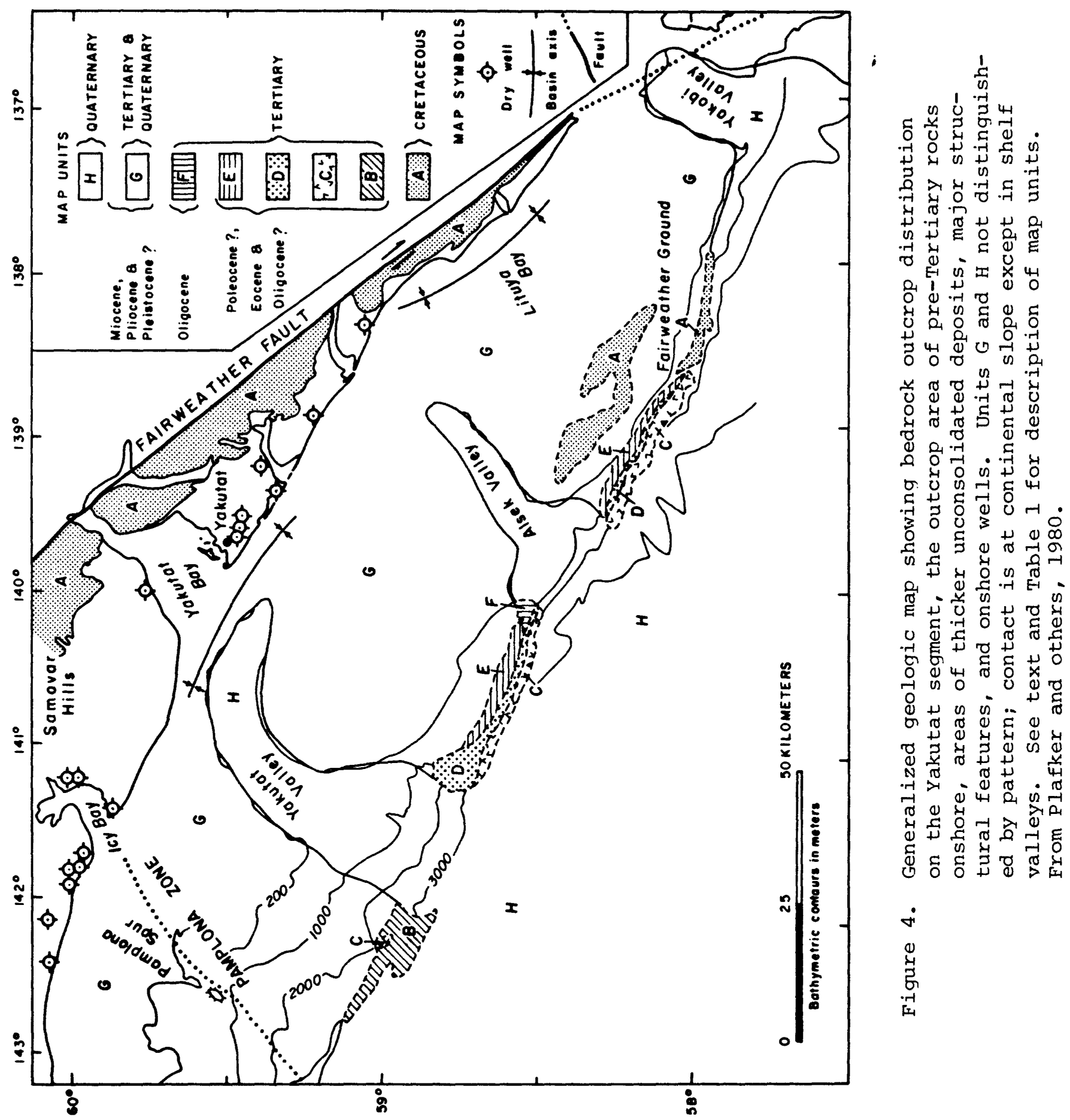




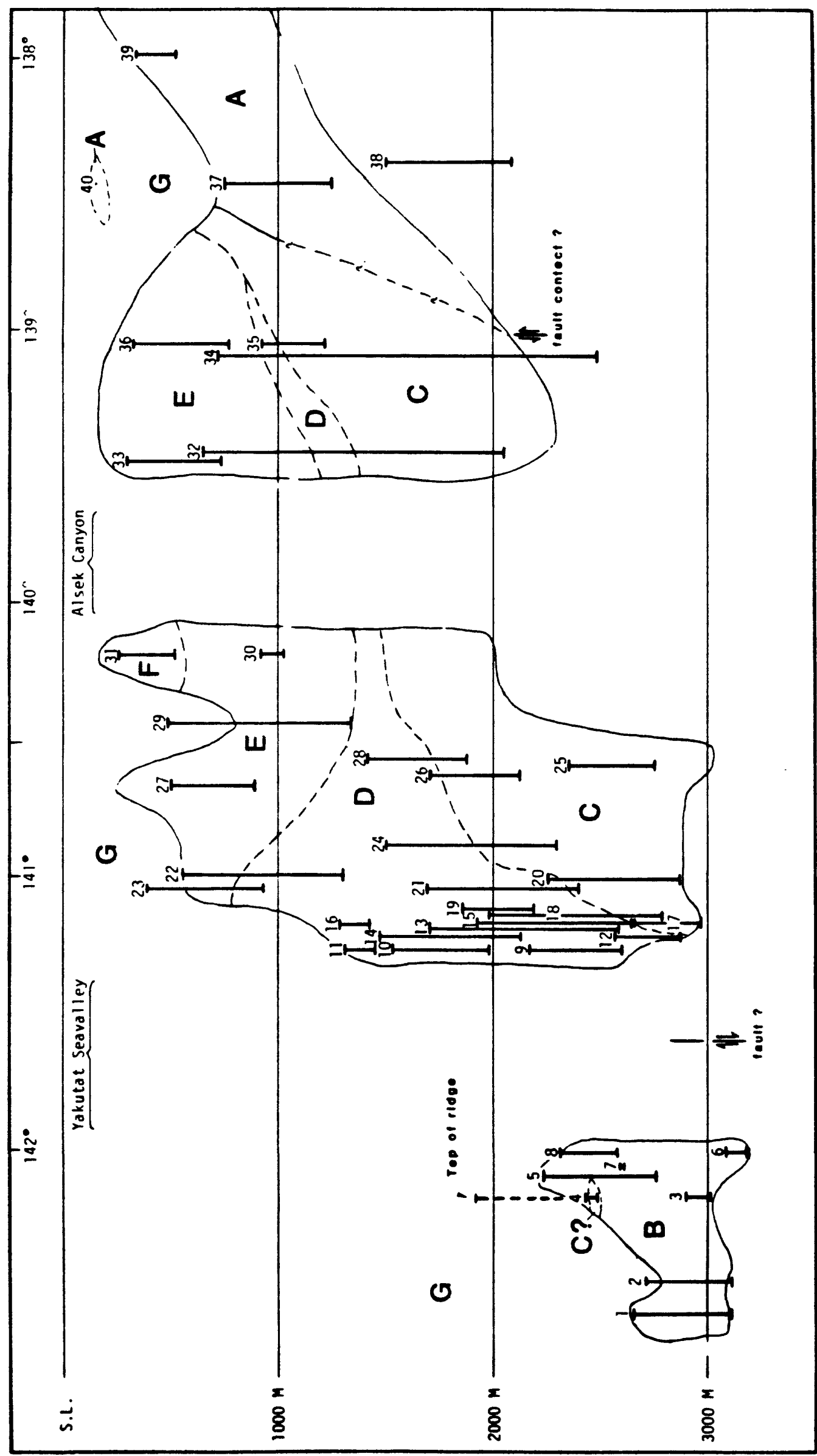

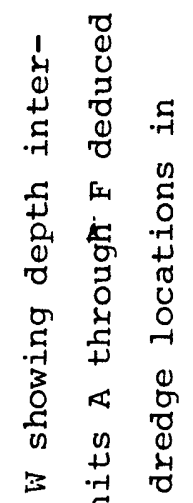

i $\Xi$

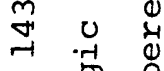

유

3 击

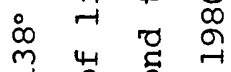

-1
0

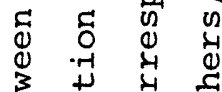

\begin{tabular}{llll}
3 & + & प & \multicolumn{1}{|c}{} \\
0 & 0 & 0 \\
0 & 0 & 0 & 0
\end{tabular}

\&

ज

ना क्त

+ व

节

范

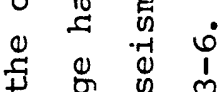

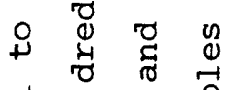

$\overrightarrow{0}$ ते

तु

\&

¿

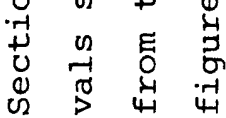

in 
refraction and reflection data, show that Paleogene rocks underlie much of the Yakataga and Middleton segments, and are present at shallow depths beneath the Middleton segment (Bayer and others, 1978; Bruns 1979, 1982; Bruns and Schwab, in press; Plafker and others, 1980, 1982). Rocks of Eocene and Oligocene age were penetrated in the lower part of the Tennaco Middleton Island Well, drilled on state lands near Middleton Island (Rau and others, 1977). These rocks can be correlated into the seismic data and underlie much of the shelf and slope (Plafker and others, 1982; Bruns unpublished data). Seismic reflection data and well control also show that strata coeval to the yakataga Formation underlie the continental shelf and much of the slope of the Yakataga and Middleton segments (Bruns, 1979, Bruns and Schwab, 1982).

\section{GEOLOGIC HISTORY}

The following summary of geologic history is taken from work in progress by T. R. Bruns and George Plafker and from Stonely (1967); Plafker (1971); Plafker and others (1975, $1978 \mathrm{a}, \mathrm{b}, \mathrm{)})$; Rogers, (1977); Jones and others $(1977,1981)$; Bruns $(1979,1982)$; von Huene and others (1979); Perez and Jacob (1980); Lahr and Plafker (1980); and Bruns and Schwab (in press) The southern margin of Alaska began to assume its present form in about mid-Cretaceous time by assembly of several northward-moving microplates, including the Alexander Terrane and Wrangellia, against Precambrian to middle Paleozoic rocks of nuclear Alaska. During the Campanian and Maestrichtian, a volcanic arc developed along the continental margin as a result of relative under-thrusting by Pacific oceanic crust. During the existence of this arc, a volcanogenic flysch and melange sequence with subordinate oceanic basalt (Chugach Terrane) was accreted along the continental margin northwest of Chatham Strait in a continuous belt up to $100 \mathrm{~km}$ wide, a subparallel volcanoplutonic arc was developed on continental crust to the north of the accretionary belt, and shelf deposits were laid down in an arc-trench gap basin.

A redistribution of plate motions at the beginning of the Tertiary resulted in northeastward movement of Pacific oceanic crust relative to the Alaska continental margin. As a consequence of these relative plate movements, ensimatic deep sea fan deposits and associated oceanic tholeiitic basalts of late Paleocene and early Eocene(?) age that comprise the Orca Group and related rocks were accreted along the western part of the area to form a belt with an exposed width of $110 \mathrm{~km}$ that probably also underlies much or all of the continental shelf west of Kayak Island. These deep sea rocks are complexly deformed, mildly metamorphosed, and locally intruded by granitic plutons.

During middle to late Eocene time, deposition at the continental margin became regressive, with development of a thick coal-bearing lagoon, barrier beach, and delta complex. The complex was supplied largely by sediment derived from erosion of the now uplifted Cretaceous to early Tertiary accretionary sequences and from granitic plutons emplaced in them. Bedded rock units include the Kushtaka, Kulthieth, and Tokun Formations.

Transgression occurred during oligocene and early Miocene time, and predominantly shaly sediment accumulated, in part organic-rich, and intercalated with water-laid alkali basaltic tuff, breccia, and pillow lava. These bedded rocks comprise the Katalla, Poul Creek, and Cenotaph Formations. 
The present sedimentary and tectonic regime (fig. 6) results from movement of the Pacific plate and an attached allochthonous microplate, the Yakutat block (composed of the Yakutat and Yakataga segments of the continental margin), northwestward relative to the Alaskan continental margin since the early Miocene. Due to these motions, the Aleutian Trench and associated volcanic arc developed by underthrusting of the Pacific plate and attached Yakutat block beneath the continental margin in the western Gulf of Alaska, the high Chugach-St. Elias range developed as a result of collision and underthrusting of the Yakutat block in the northern Gulf of Alaska, and dextral transform faulting prevailed along the Fairweather-Queen Charlotte Fault along the eastern and northeastern margin of the Gulf of Alaska.

From the middle Miocene to the present, an enormous thickness of clastic sediment comprising the Yakataga, Redwood, and Topsy Formations, and including much glacially-derived material, was rapidly deposited in a predominantly shallow shelf environment. Concurrently, deep-water sediments were being deposited in slope basins and at the base of the slope. Simultaneous compression related to plate convergence has resulted in complex folding and thrust faulting of the bedded Neogene rocks throughout much of the Gulf of Alaska, together with large-scale strike-slip faulting in the eastern Gulf of Alaska. An additional consequence of these motions is that the Paleogene rocks of the Yakutat block have been transported northward with the Pacific plate, from an original depositional position that was most likely of $f$ southern Bxitish Columbia.

\section{OFFSHORE STRUCTURE}

The structure and stratigraphy of the Gulf of Alaska continental margin are interpreted from a regional network of multichannel seismic data (fig. 7). These data are correlated with dredged rocks of Plafker and others (1978c, 1979, 1980) and with onshore and offshore wells to give approximate ages of structural horizons interpreted on the seismic data. Depth conversion of the seismic data is based on velocity logs from wells and on offshore refraction and reflection velocity data (Bayer and others, 1978; Bruns, 1979, 1982; Bruns and Schwab, in press).

The multichannel seismic data indicate that the continental margin is geologically complex with markedly different structural styles in the southeast Alaska, Yakutat, Yakataga, and Middleton segments. Figures 8-20 show seismic lines and the major structural features for each of the areas, either by line drawings of the seismic sections (southeast Alaska), or with seismic sections, structural contour maps and isopach maps. Published interpretations of the seismic reflection and refraction data include Bruns and Plafker (1975), Bayer and others (1978), Bruns (1979, 1980, 1982), and Bruns and Schwab (in press).

\section{Southeastern Alaska}

In the southeastern Alaska segment, the currently active trace of the Queen Charlotte-Fairweather fault system lies near the outer shelf and upper slope from Dixon Entrance to Cross Sound, then cuts across the shelf to join the onshore Fairweather Fault (fig. 8; Carlson and others, 1979; Bruns, 1980).

Landward of the active fault trace, acoustic basement is either shallow 


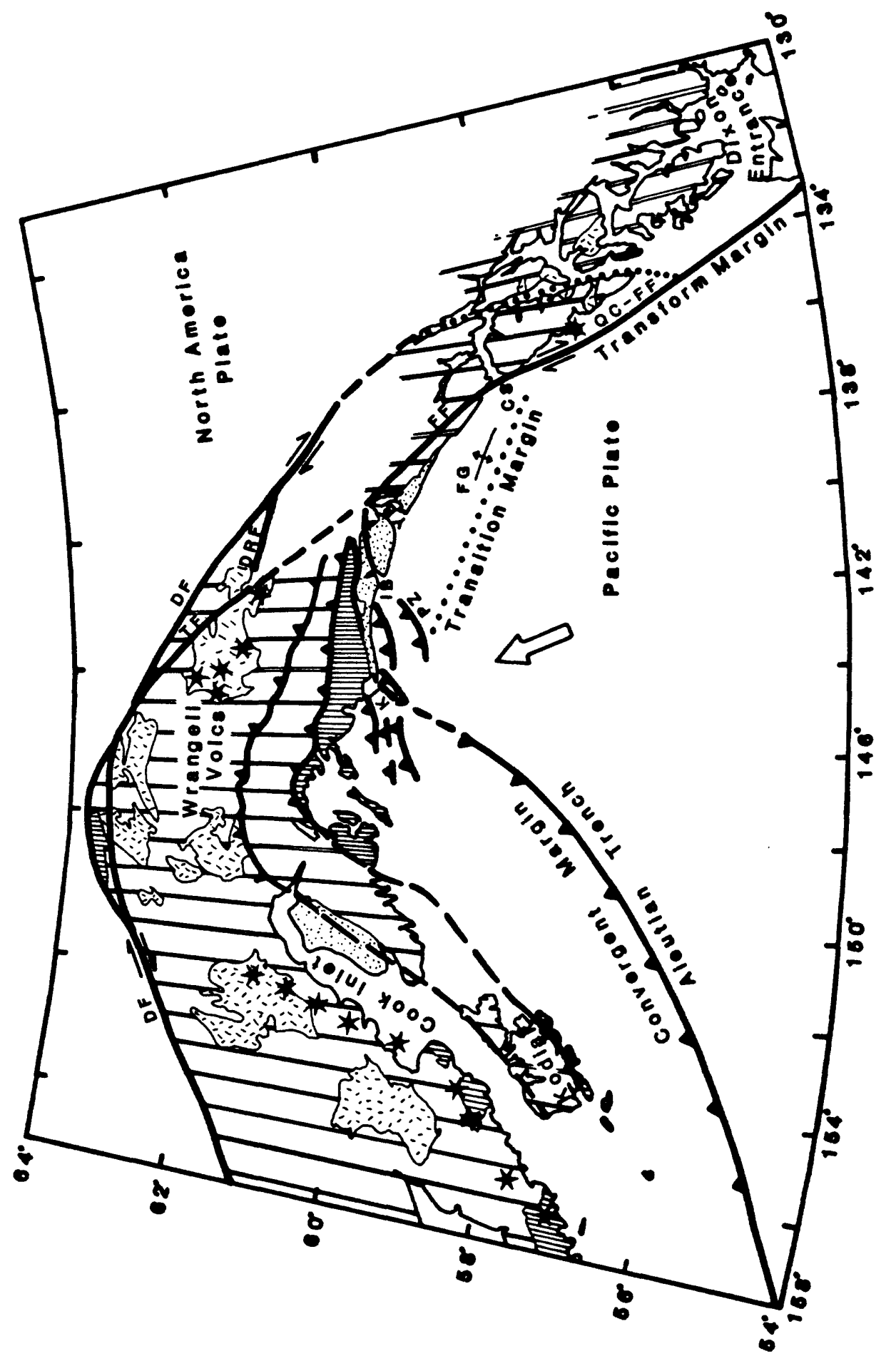

III

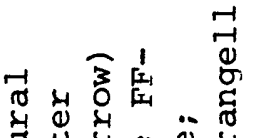

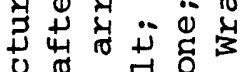
弐焉留 का कु

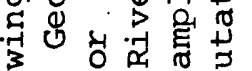
O I $001 \frac{1}{0}$ क है $x$ o \& $1 .$.

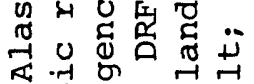

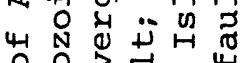
0 O 54 4

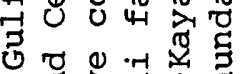
进?

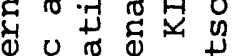
$\{\rightarrow-0$ 오원

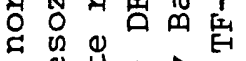
व

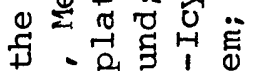
造 出

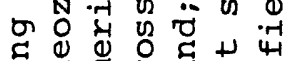
. $\stackrel{\otimes}{-1}$ 近

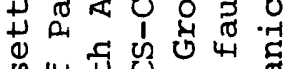
का 4 पु

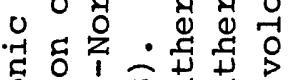
o

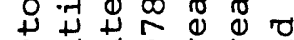
0 \% 333 म $\Rightarrow$ व व 0 出 की ठठ대 4 - 7 0 म. त

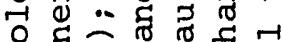

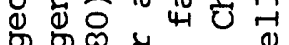
त न (1) ह क स द

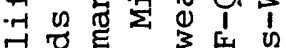

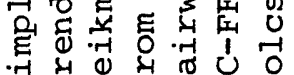

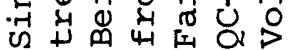

$\dot{0}$

मू 


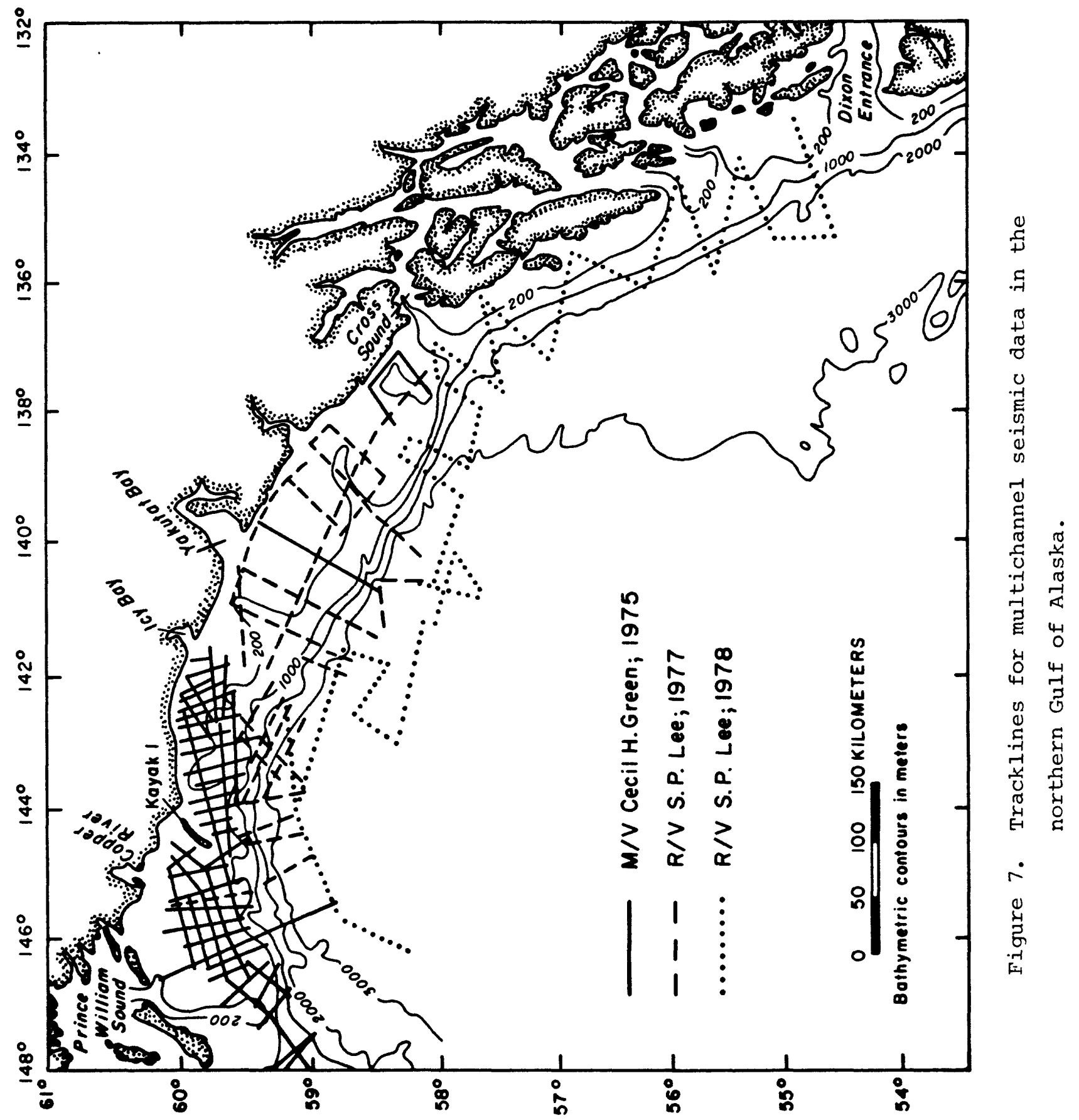




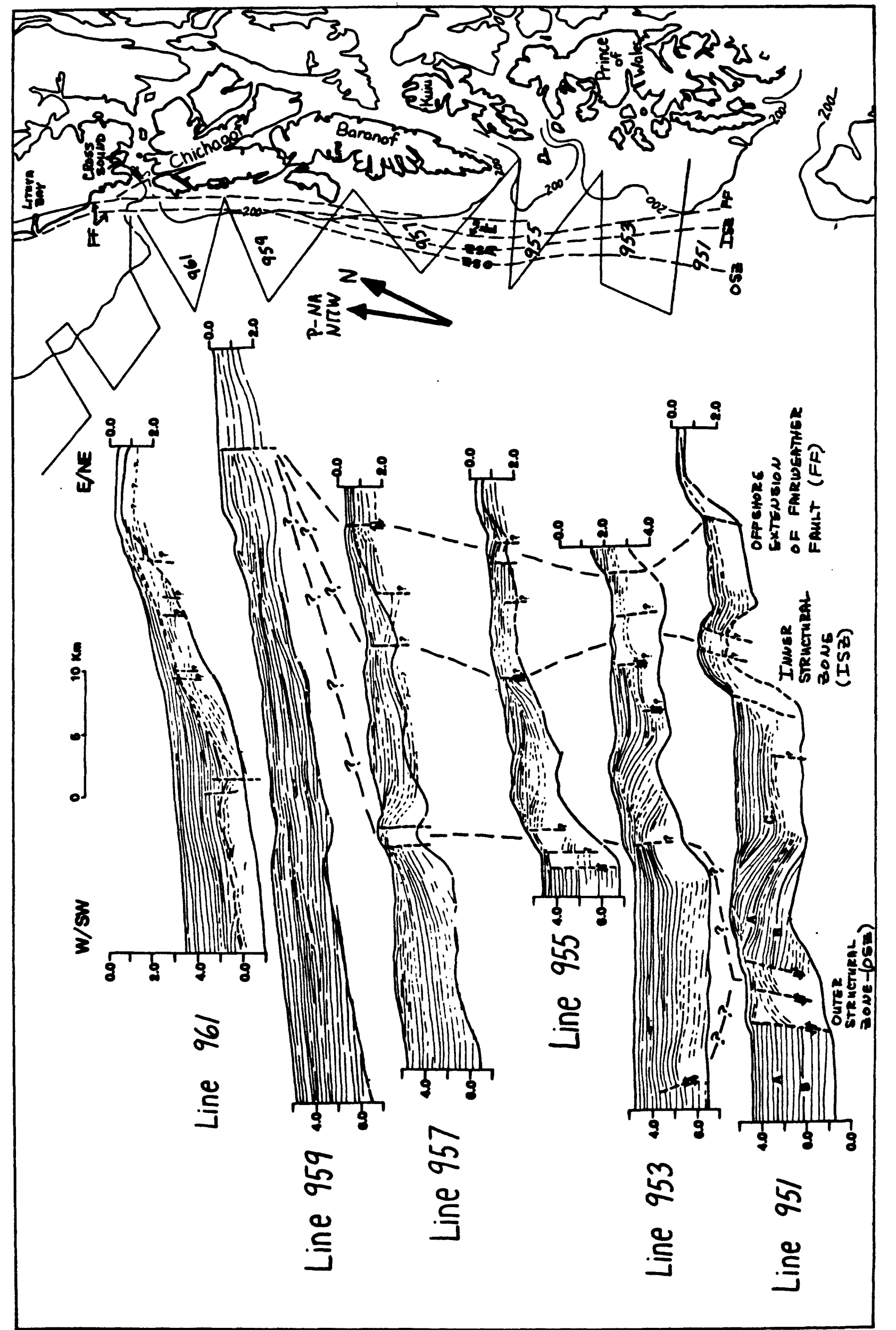

+

๑)

है

원

出些号

舟 0

Q

$\rightarrow$ त

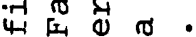

으

मे

บ

ज 0

- 5 号

ט.

山故

पी

이각

न 0000

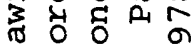

过 $N$.

(1) 出 न्ष

द 0 శึ

$\rightarrow$ o

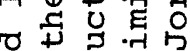

त्ष $थ$ के

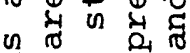

I 50

व

के ठ

$\rightarrow$ व

ชี ซี ฐ

马ु -

近 0 。

곡

म

山被出

过

5

-

Tत

0 政

$\rightarrow$ क 0 .

ठ प्र

0 n 0

ज ह

\% U.

乎 $-\widehat{N} 0$

ఫ

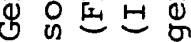


or at the seafloor between Dixon Entrance and Chatham Strait, and little structural information can be interpreted from the seismic data. Rocks beneath much of the shelf are apparently highly consolidated, and are likely similar to Mesozoic and Paleozoic rocks exposed in the adjacent onshore areas. Between Chatham Strait and Cross Sound, a probable Neogene and quaternary age sedimentary wedge, with a maximum thickness of about $2.5 \mathrm{~km}$ is present beneath the outer shelf. These strata thicken seaward and are; truncated at the Fairweather fault (fig. 8).

Seaward of the Fairweather fault trace, a sedimentary section ranging from 3 to at least $5 \mathrm{~km}$ thick underlies the continental slope (fig. 8). This section is interpreted to be Miocene and younger based on the age of oceanic magnetic anomalies and on a seismic correlation to rocks sampled in DSDP hole 178 (Bruns, unpublished data).

From Dixon Entrance to Chatham strait, folds and faults within this section are most likely wrench folds associated with the extension of splays of the Queen Charlotte-Fairweather fault system across the continental slope. Folding occurs in two zones (fig. 8; lines 951, 953 and 957). Individual structures within these zones forms an en-echelon pattern typical of deformation in a strike-slip tectonic setting (Harding and Lowell, 1979). The folds at the base of the slope are probably Quaternary features. Folding in each of the structural zones decreases in magnitude to the north. Bet ween Chatham strait and Sitka only minor deformation of the slope section is seen on the seismic records (fig. 8, line 957), and between Sitka and Cross Sound, strata seaward of the Fairweather fault trace are undeformed (fig. 8, line 959). In the vicinity of Cross Sound, abyssal strata appear to onlap the continental margin (fig. 8, line 961). Undeformed strata at the base of the slope are about 3 to $4 \mathrm{~km}$ thick, and thin seaward.

\section{Yakutat Segment}

The Yakutat segment is bounded by the Fairweather fault, the base of the continental slope, and the initial folds of the Pamplona zone, a zone of broad folds and faults west of Icy Bay and beneath the Yakataga segment (fig. 9). The structural character is illustrated by contour maps and four seismic lines (figs. 10-14; Bruns, 1982).

The basement structure of the Yakutat segment is shown by contours on the acoustic basement, which corresponds to the top of Eocene basalt in the western part of the Yakutat segment and to probable Cretaceous or early Tertiary rocks in the eastern part. The basement map shows three major structural features: 1) a large structural high at the shelf edge that is centered on Fairweather ground; 2) the Dangerous River zone, extending from the western edge of Fairweather ground towards the mouth of the Dangerous River, along which acoustic basement shallows abruptly by about $2 \mathrm{~km}$ from west to east, and 3) two subbasins separated by the Dangerous River zone and with their axis near the coast (fig. 10).

Strata of Paleogene age coeval with the dredged Eocene and Oligocene sedimentary rocks are present in the western subbasin. An isopach map of these strata shows that they range from about $2 \mathrm{~km}$ thick in outcrop at the continental shelf to greater that $4.5 \mathrm{~km}$ thick near Icy and Yakutat Bays (fig. 11). These strata onlap or are faulted against the acoustic basement along 


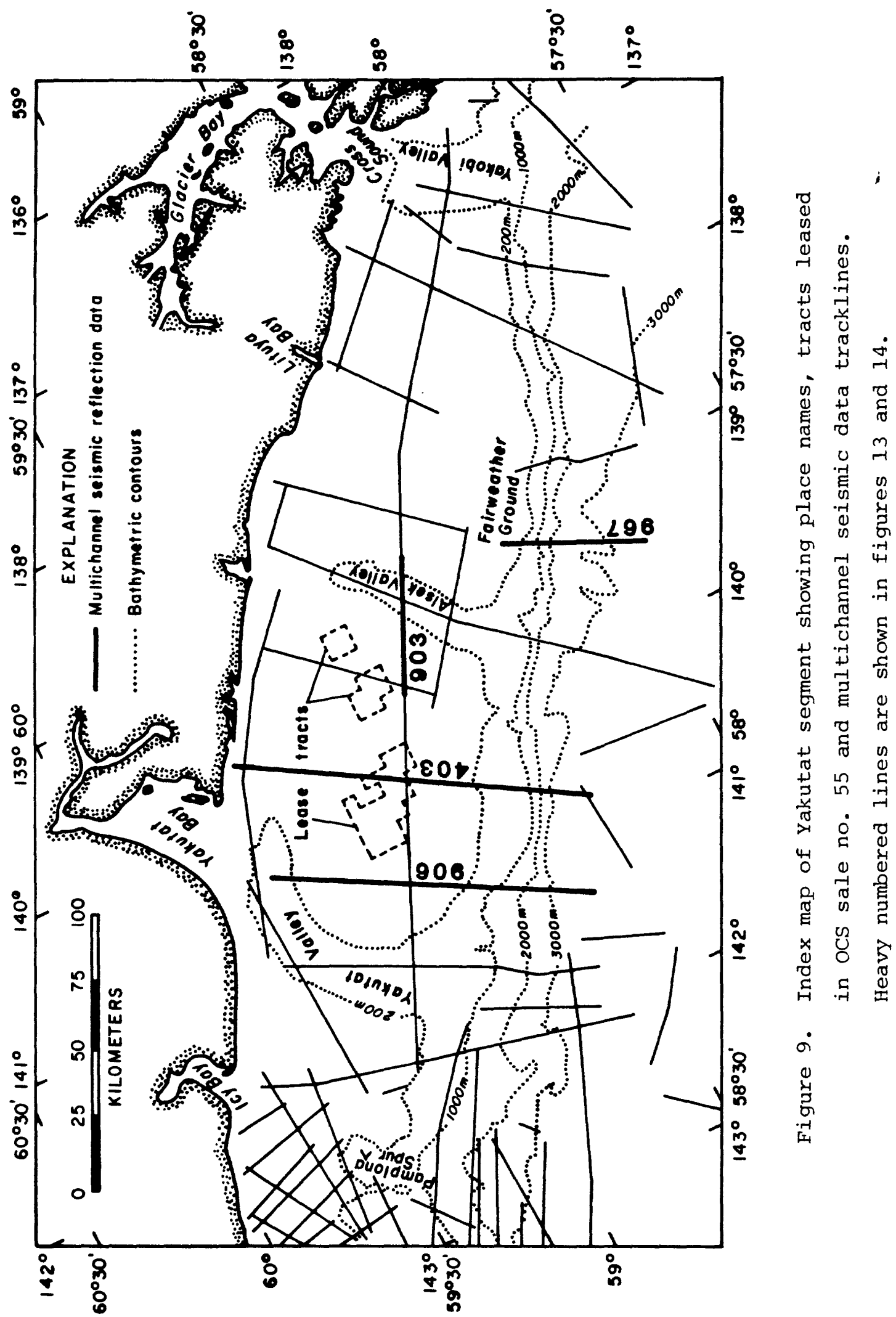




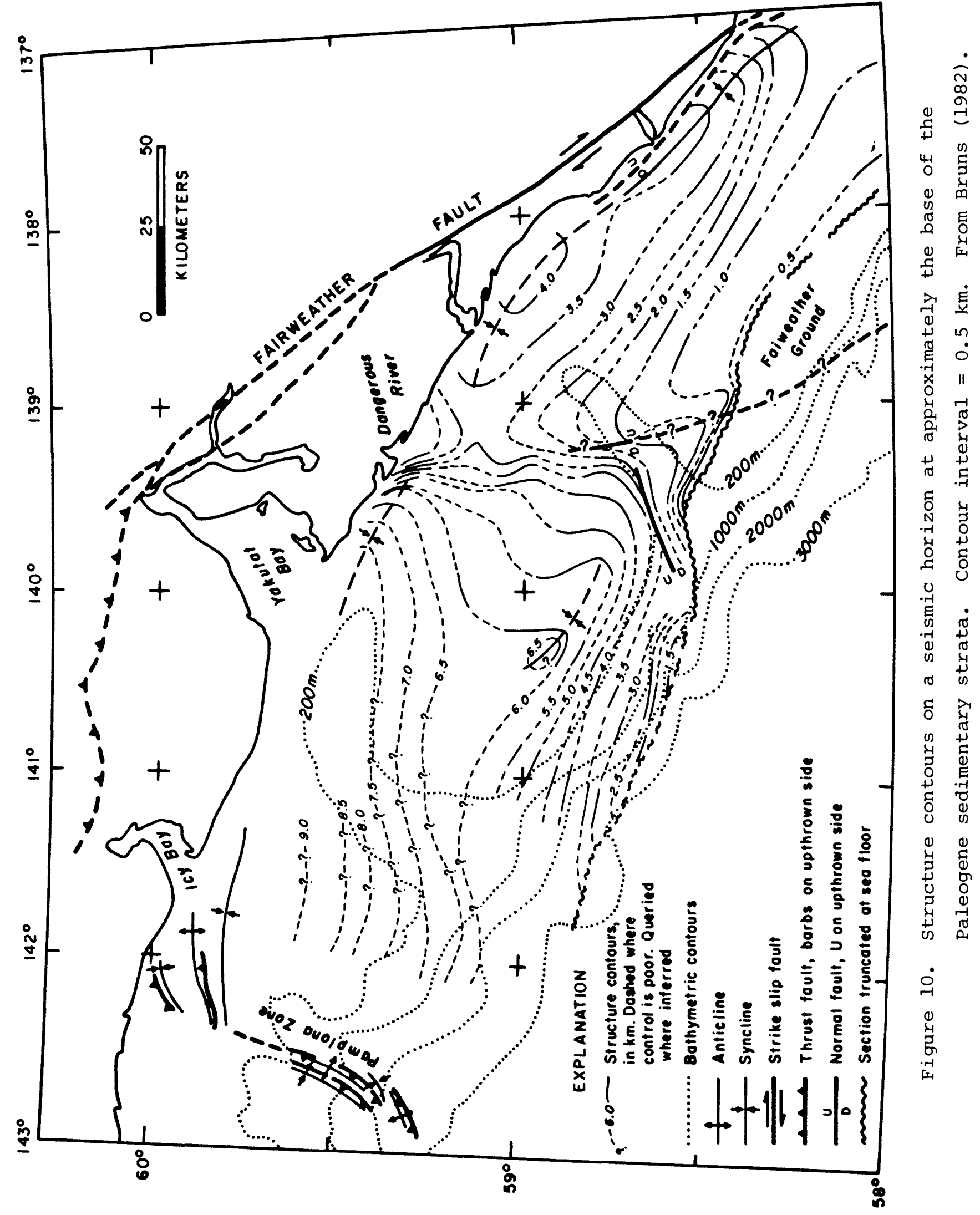




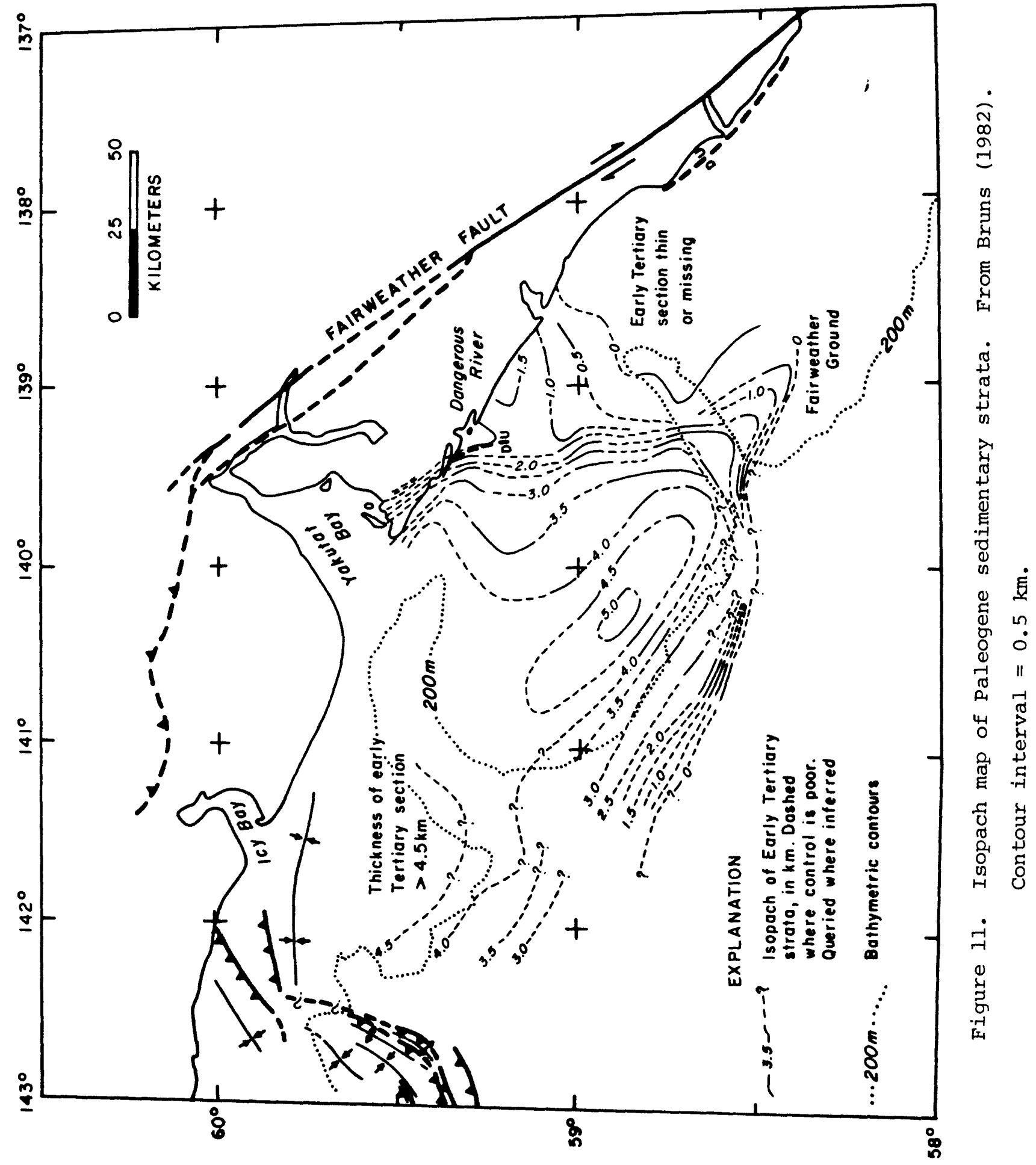




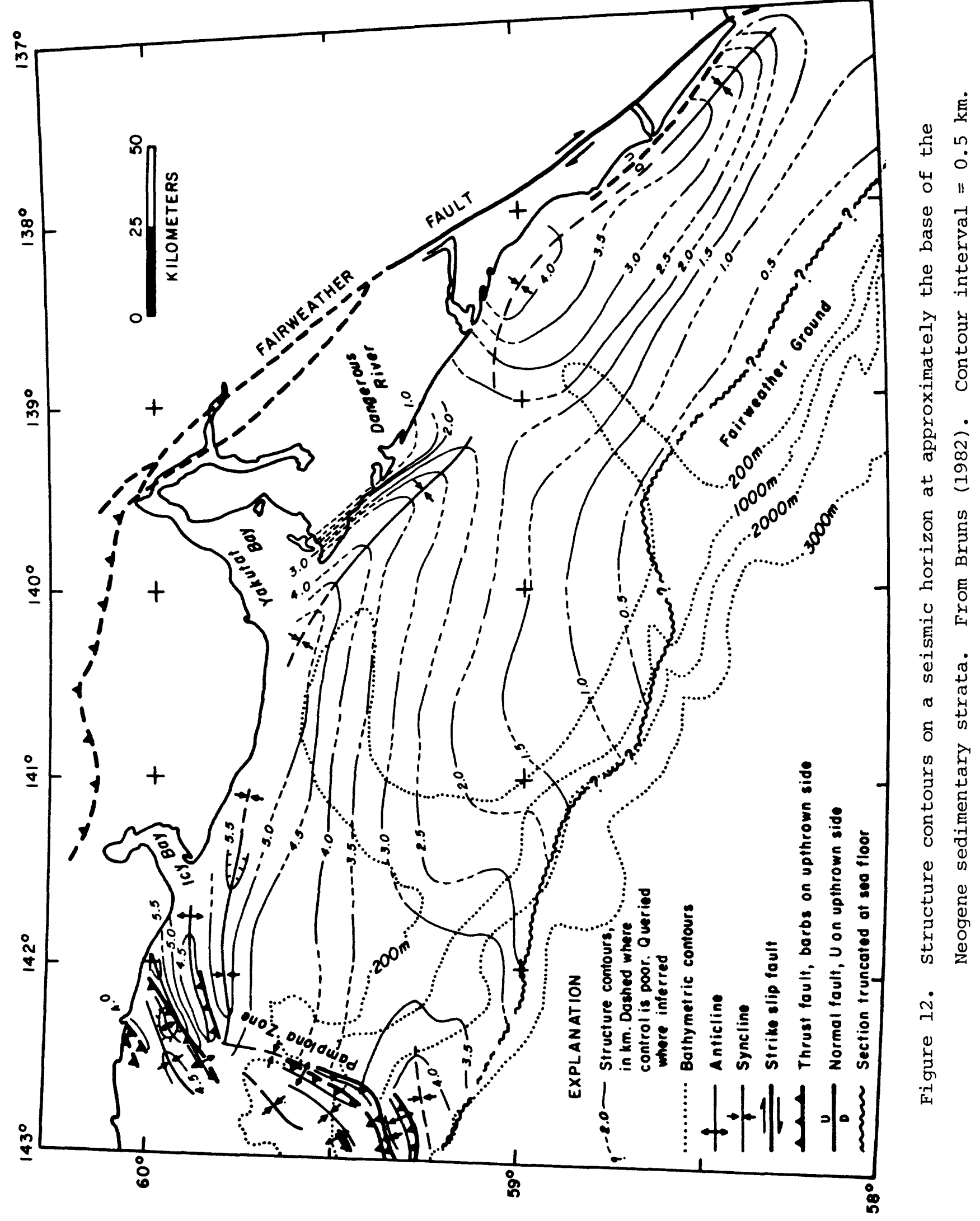



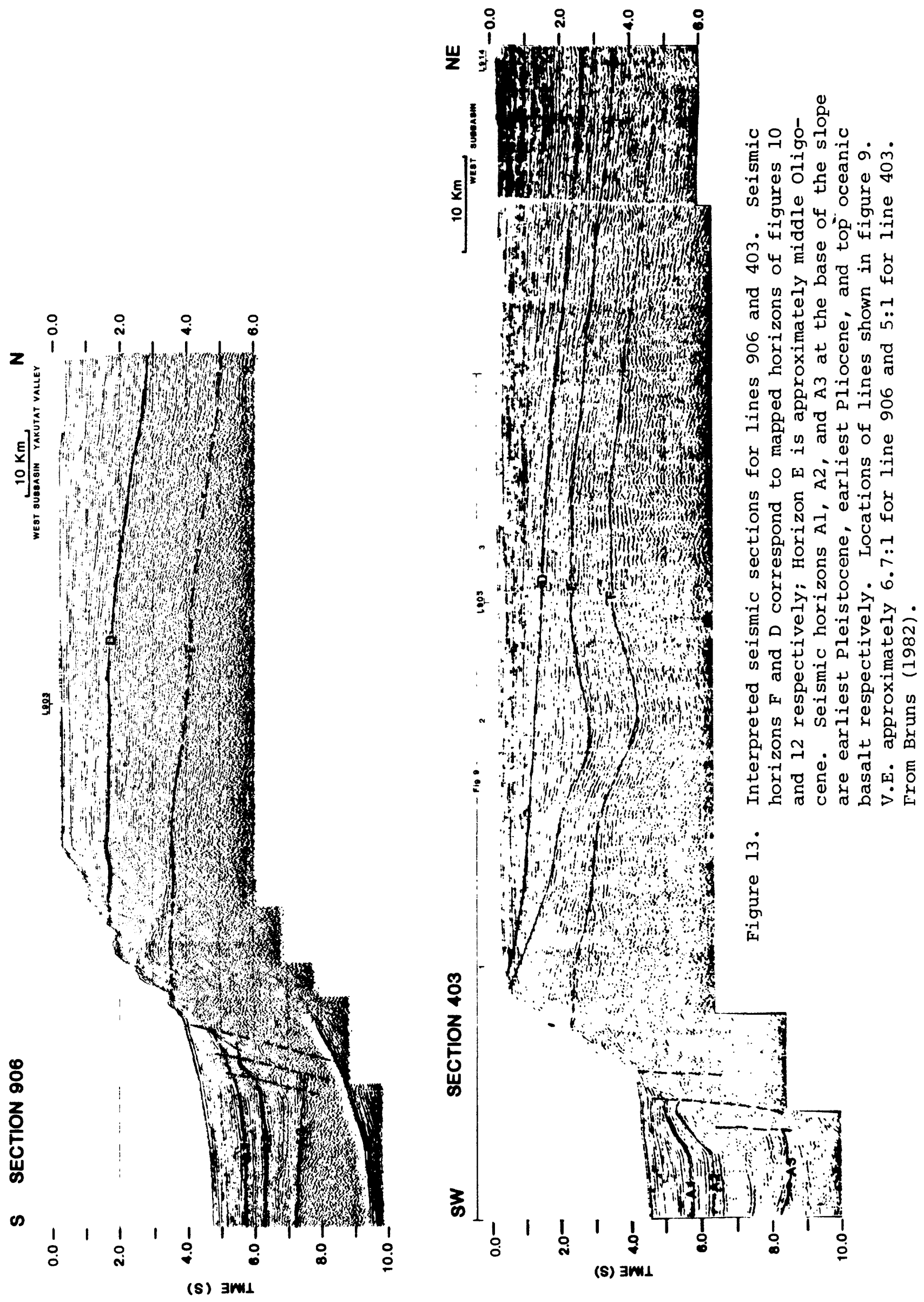


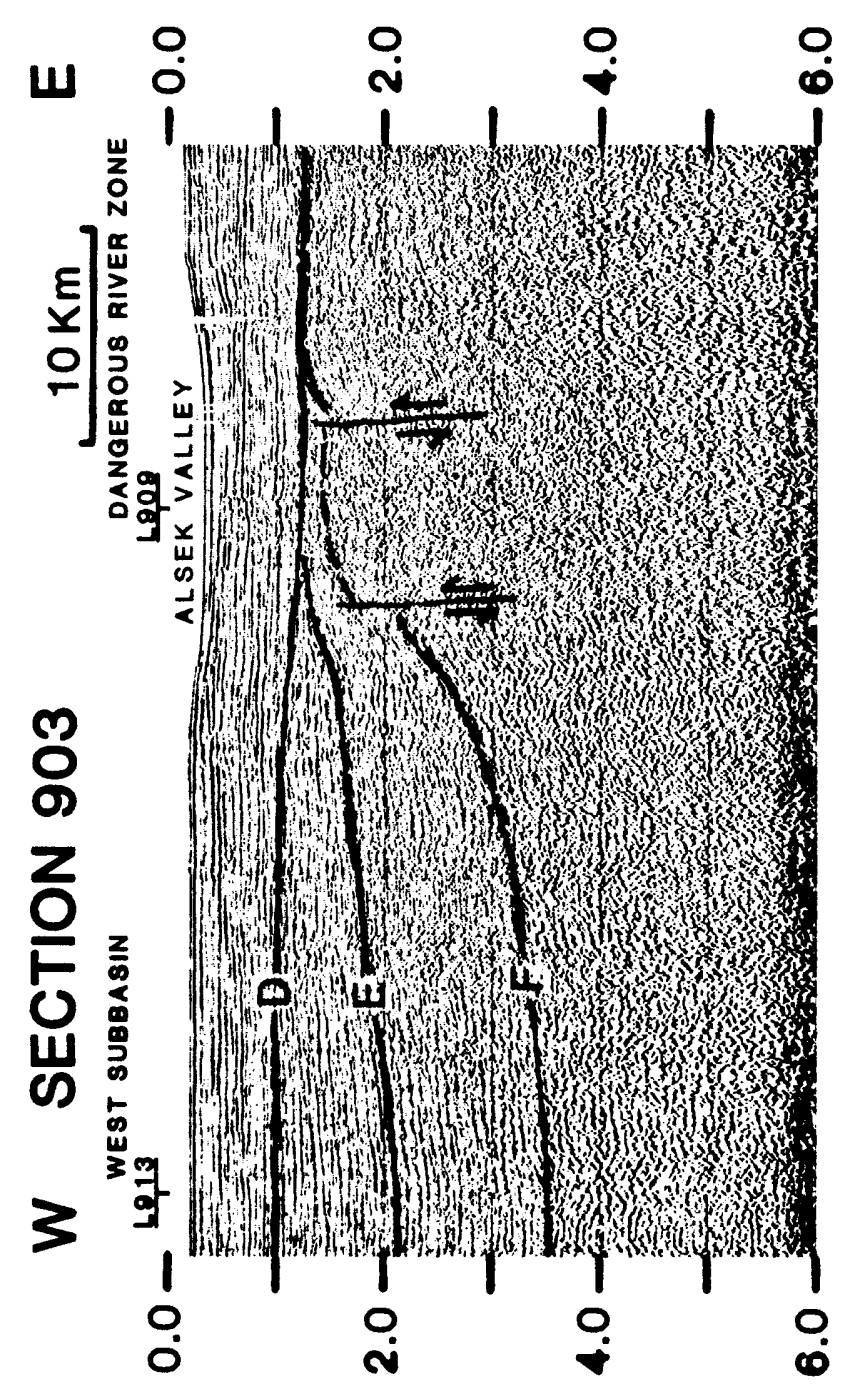

(s) $\exists W I \perp$

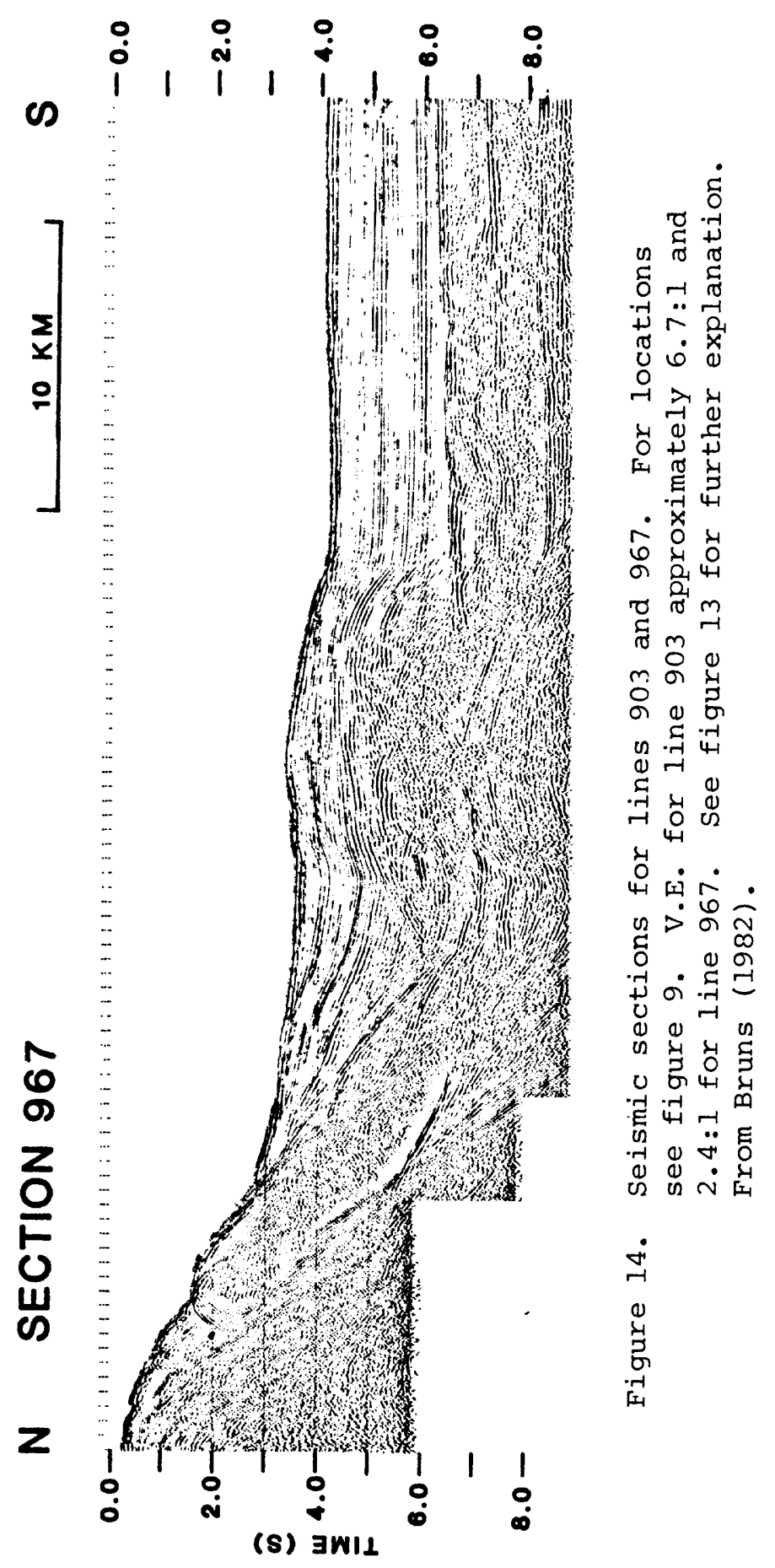


the Dangerous River zone and are either thin or not present in the eastern subbasin. A large, gently folded anticline is present in the Paleogene strata of the western subbasin, and this anticline is unconformably overlain by undeformed strata of late Oligocene and younger age (figs. 11, 13, 14). This structure was the major target for tracts leased in ocs lease sale no. 55 (fig. 9).

The Paleogene strata in the western subbasin and acoustic basement on probable Cretaceous rocks in the eastern subbasin are in turn unconformably overlain by late Cenozoic strata equivalent to the Yakataga Formation. These strata dip towards the coast into a basin with the axis near the coast. A structure map at the base of the late cenozoic strata shows the maximum thickness of these strata is about $4 \mathrm{~km}$ in the eastern subbasin, and up to 6 $\mathrm{km}$ between Yakutat and Icy Bays (figs. 12-14). The late Cenozoic strata show only regional dip except in three areas; 1) on a gently folded anticline trending onshore near the Dangerous River; 2 ) in a narrow zone near Lituya Bay, and 3) locally over Fairweather Ground. The deformation on the anticline near the Dangerous River may be due to minor reactivation of uplift on the northern extension of the Dangerous River zone. The deformation near Lituya Bay appears to be related to a major fault that parallels the coastline. Seismic data within $3 \mathrm{~km}$ of the coast show flat lying late Cenozoic strata (Bruns, 1982), while the coeval onshore strata are highly folded, with 900 dip at the coastline (Plafker 1967; 1971). Dredged rocks indicate that the Fairweather Ground high is cored by rocks primarily of Mesozoic to early Tertiary age (Plafker and others, 1980) and is onlapped by strata of late Cenozoic age. The late cenozoic strata locally show uplift and truncation over the high.

At the base of the slope, abyssal strata are as thick as $6 \mathrm{~km}$ and thin seaward to about $2 \mathrm{~km}$ at a distance of about $60 \mathrm{~km}$ from the base of the slope. The lower half of this section is of probable oligocene to Miocene age, while the upper half is of probable Pliocene and younger age. The upper strata onlap the continental slope, while the lower strata are truncated by faulting against the strata underlying the slope (figs. 13, 14). Several major folds are present in the strata at the base of the slope, primarily south of Fairweather Ground (figs. 13, 14). These folds developed during Pliocene-Pleistocene time (Bruns, 1982).

\section{Yakataga Segment}

The Yakataga segment is bounded by the folded and faulted onshore Tertiary rocks, by the eastern edge of the Pamplona zone, by Kayak Island, and by the base of the continental slope. Numerous anticlinal folds beneath the shelf were the target for leasing and exploratory drilling in OCS lease sale no. 39, 1976 (fig. 15 and Table 2). The structure of the Yakataga segment is shown by structural contours in lower to middle Pliocene strata (fig. 15), and is illustrated by four seismic lines (figs. 16, 17). The segment is discussed in detail by Bruns (1979) and Bruns and Schwab (in press), from which the following discussion is taken.

The structure of the Yakataga segment is characterized by broad folds and associated thrust faults beneath the continental shelf and slope (figs. 15 to 18). These folds and faults trend generally northeastward in the eastern part of the segment to eastward in the western part of the segment (fig. 15). 


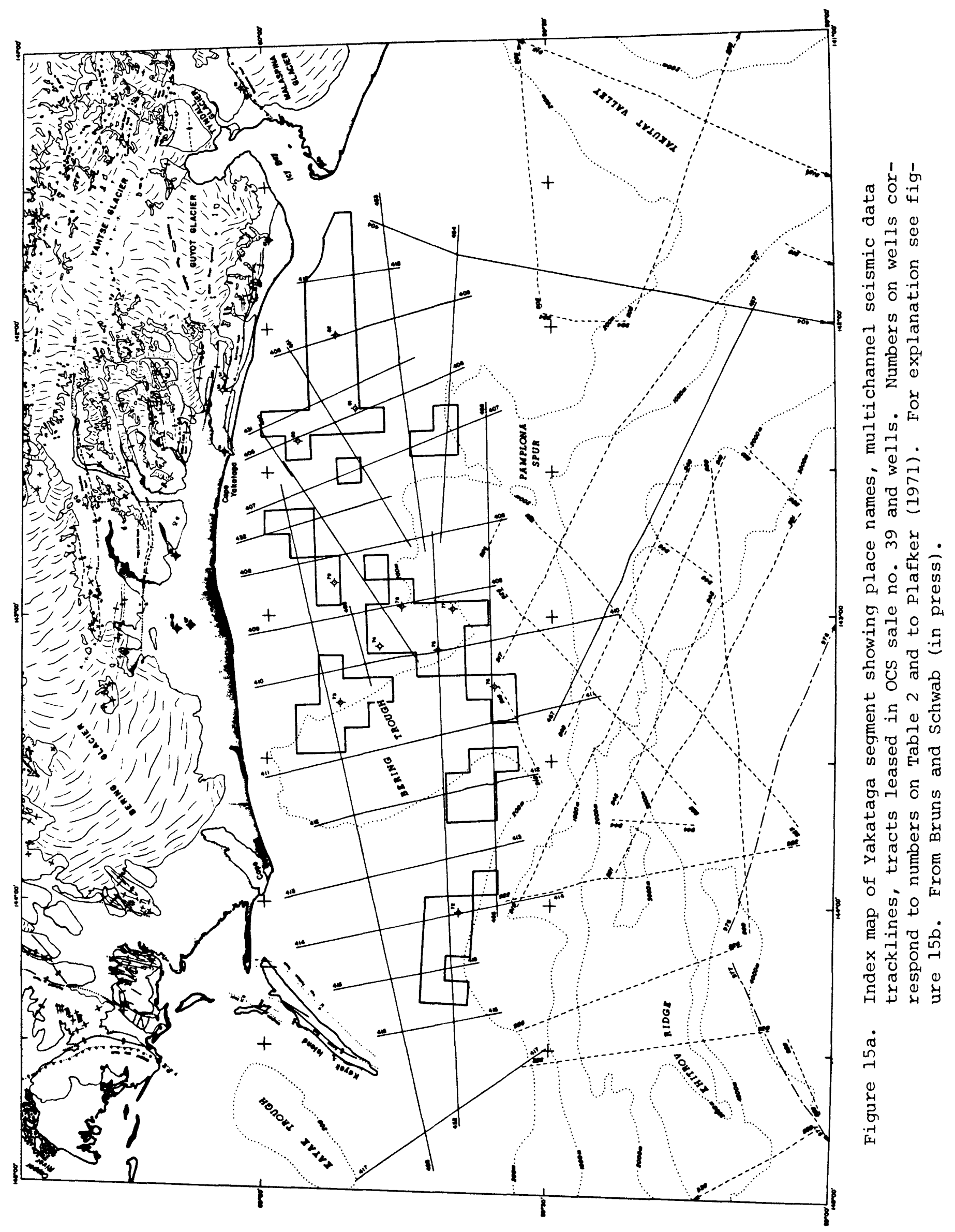




\section{EXPLANATION}

\section{ONSHORE}

7. Uncensedidated and surficlal deposits, including bete ads and alluvial, Clecial, lecustrine, end buch loposits

Bodrock oufcrop

leeflelds

$\phi^{53}$ Expleratery woll end number (numbering from Plafher, 10711

\section{FAULTS}

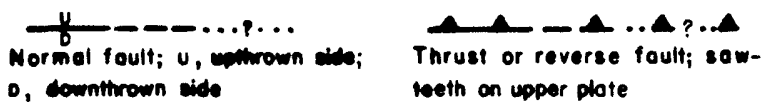

D, combitrown side Thrust or reverse foult; sawweth on upper plote

Deshed mere exproximately locoted, dotfed were cenceoted; queried where inferred

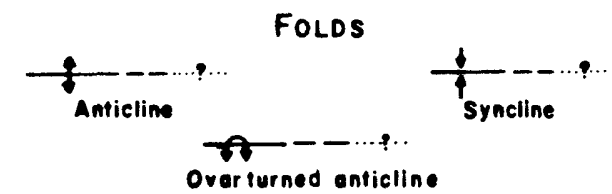

Deshed mere approximately located, dotted were concealed; fueried more inferred

\section{OFFSHORE}

multichannel seismic-reflection line, crulse EGAL- $75-1 B$ MN Cecil H. Green, 1975

222 Multichannd soismic-reflection line, cruise L6-7T-EG, R/V S. P. Lee, 1977

976 Multichannel seismic-roflection the, crulse L3-78-EG, R/V S. P. Lee, 1978

- Explorotory woll and number (see toble I)

Leese blecks, OCS sech number 39, April 1076

.. eoam.. Eathymetric contours, $1000 \mathrm{~m}$ inmerval and $200 \mathrm{~m}$ contour

(1) Structure contours in $\mathrm{Km}$. Drown on A (sheet 1), B (sheet

2. 22 2), and $C$ (sheet 3) seismlc horlzons. Contour interval

0.2 kilometer. Hochures indicata direction of dip. Con-

( 62.6 teurs doshed where control is poor or uncertain

$\sim \sim$... Truncotion of mopped herizon; cotted where truncotion is in subsurfoce

\section{FAULTS}

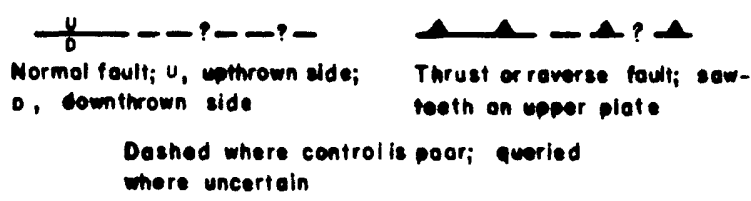

Thrust or rewerse foult; sawteeth on upeer plate

Dashed where control is poor; aceried mere uncertain

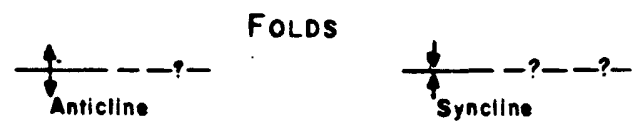

Deshed where centrol is peor; euerled where uncertain 


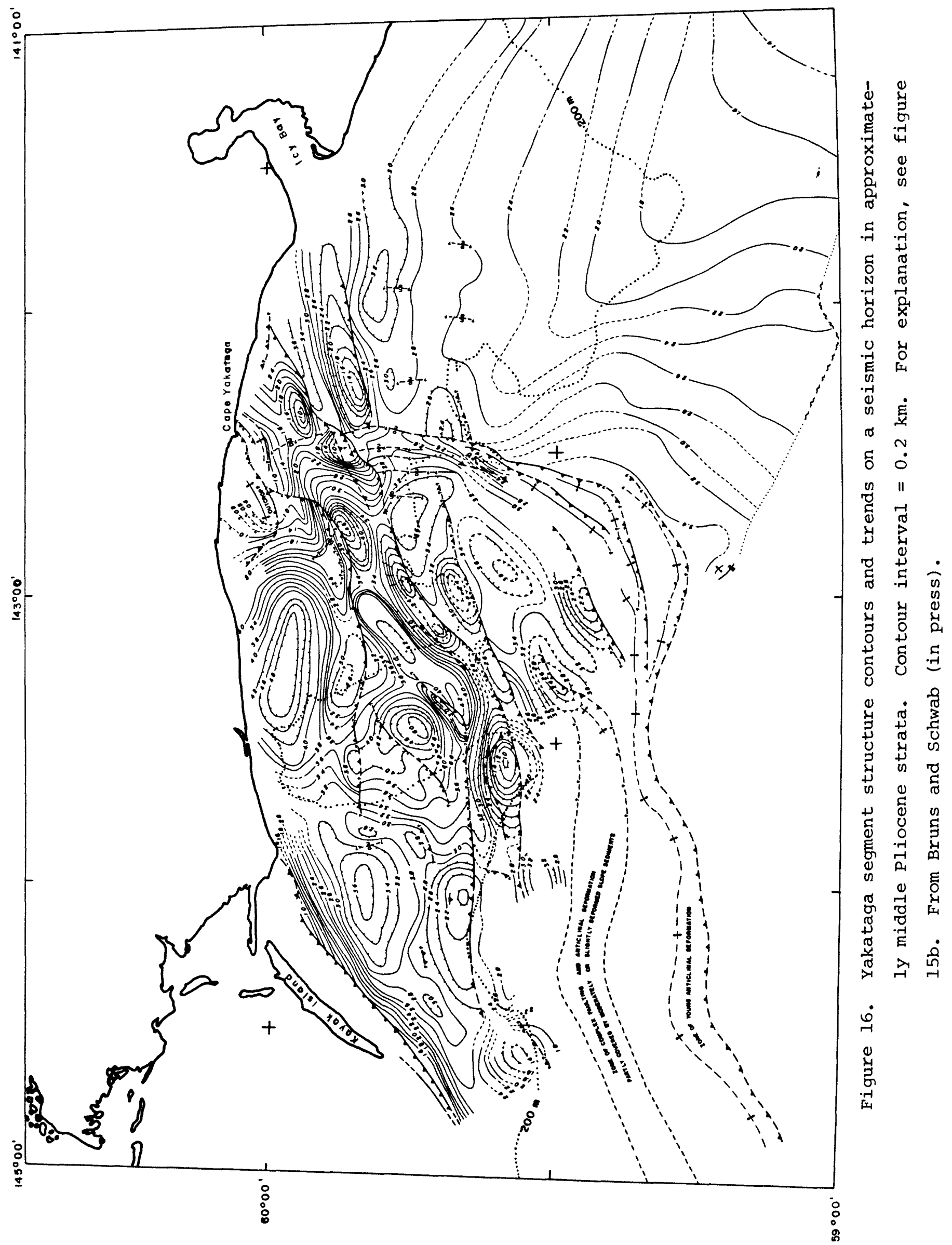



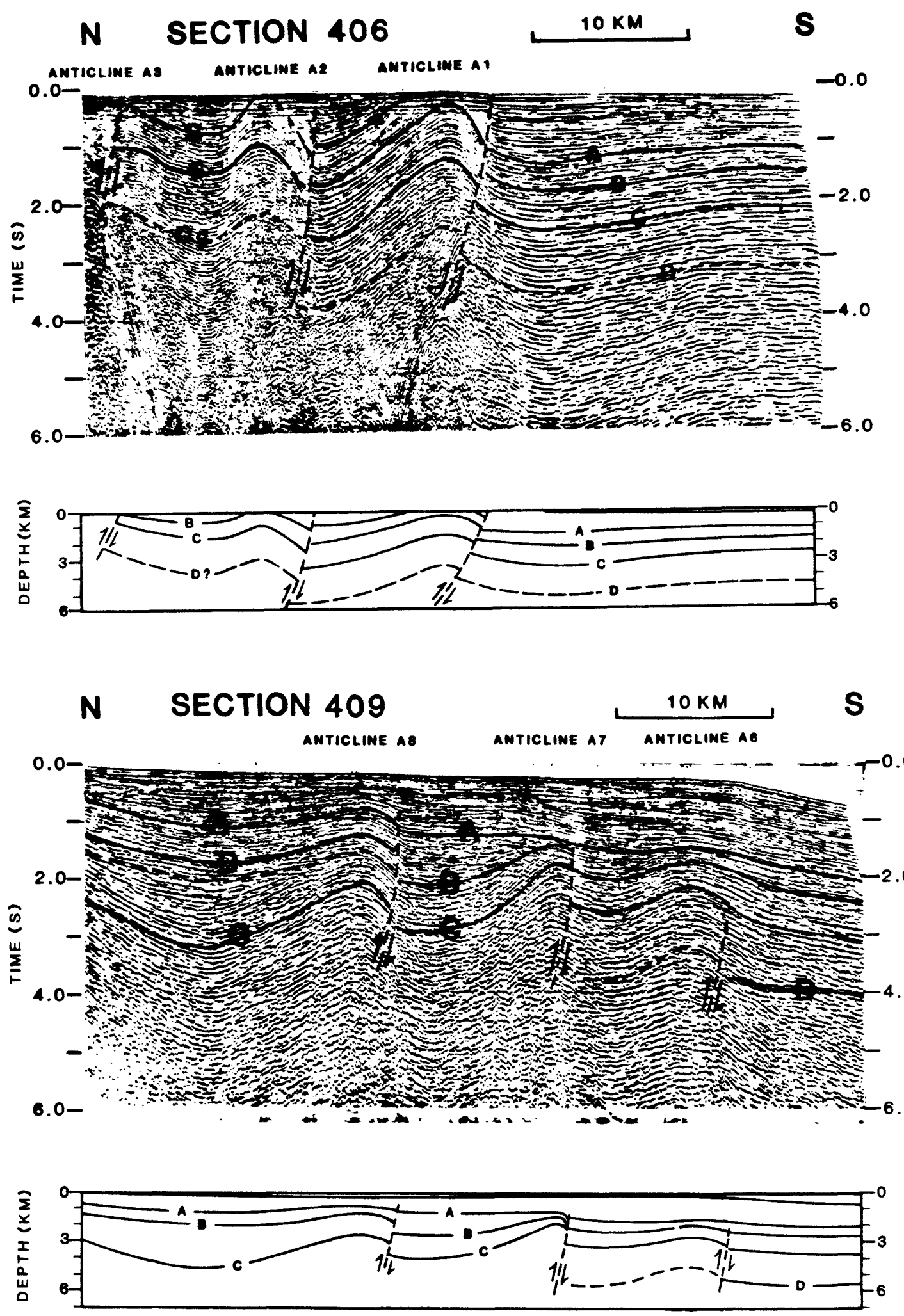

Figure 17. Interpreted seismic sections for lines 406 and 409. Seismic horizon C corresponds to mapped horizon of figure 16. V.E. is approximately 5:1. From Bruns and Schwab (in press). 

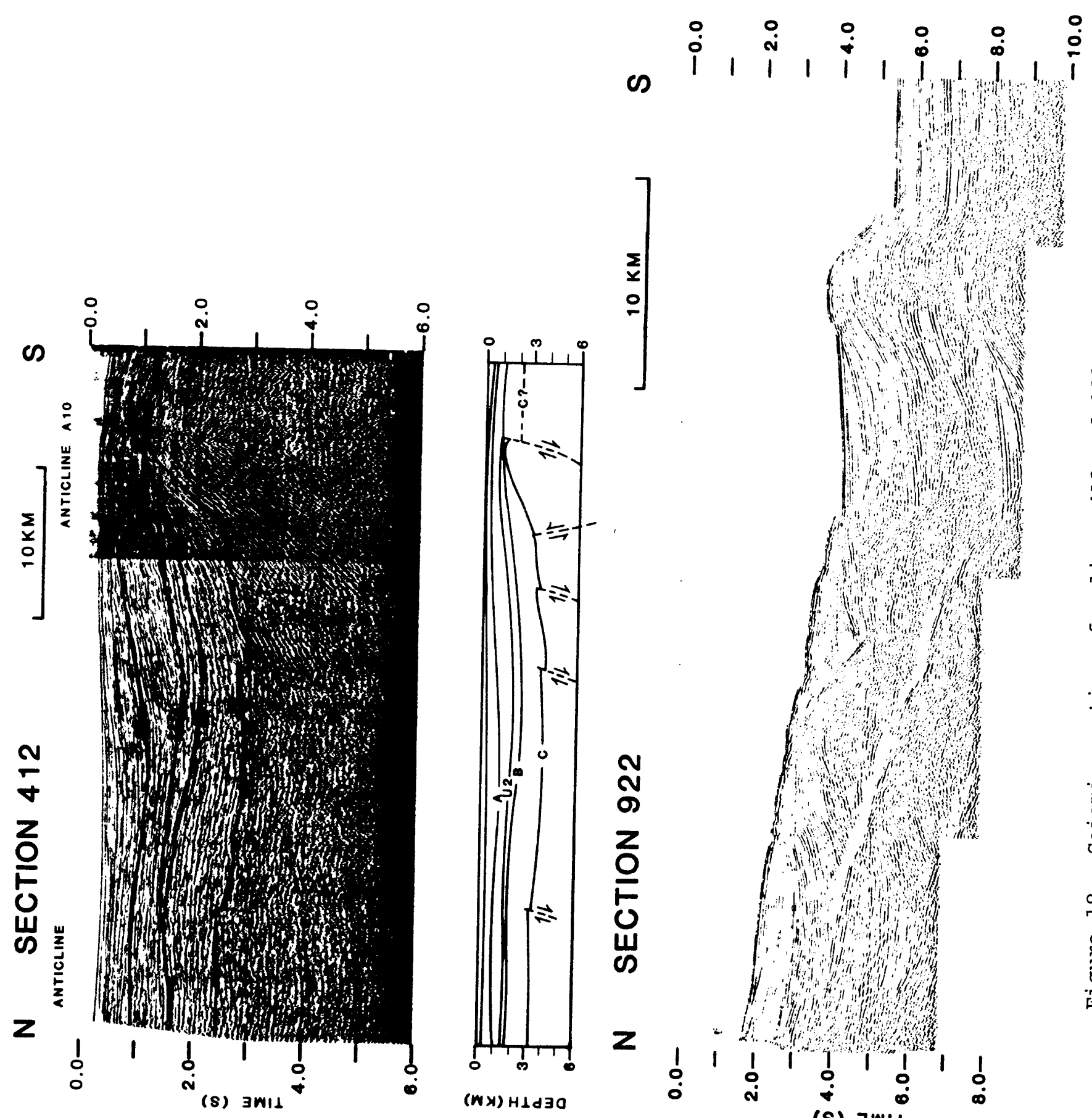

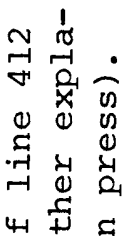

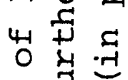

.

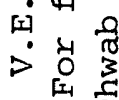

i o

๗ู

च $\dot{\sim}$

\%

テิ

o 0 ह

足

-

प्र०

फ $\ddot{-}$

路

걷서

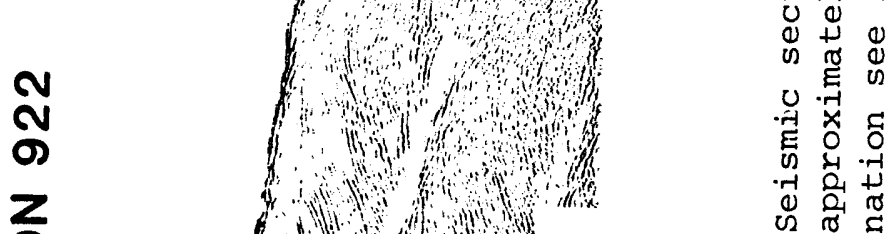

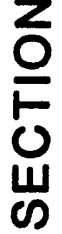

or w w

का ट्वा

$\stackrel{\infty}{+1}$

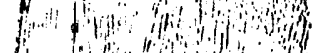

for on

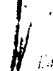

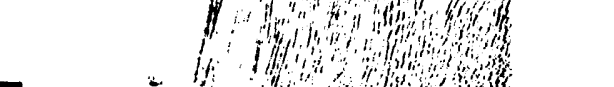

近

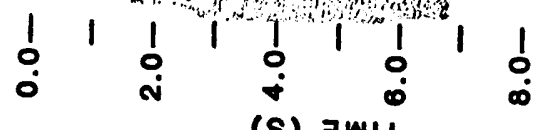

(s) $\exists W I 1$ 
Anticlines are generally asymmetric and doubly plunging and are commonly bounded on the seaward side by high angle thrust faults. Width of individual structures ranges from about 4 to $10 \mathrm{~km}$, and closure on the lower Yakataga horizon along strike is present for distances of about 15 to $40 \mathrm{~km}$. Dips on the flanks of the anticlines commonly range between 5 and $15^{\circ}$ on the landward side from 5 to $30^{\circ}$ on the seaward side. The amount of deformation is most severe in the northern part of the shelf and onshore, and deformation decreases in severity seaward (figs. 15-18).

The age of the structures decreases to the south and southeast and shows an overall deformation pattern of southeastward migration through time. Structures of similar age generally define three structural zones, with deformation within each zone ocurring at about the same time. Deformation of a particular structure or structural age zone is followed by a combination of regional subsidence of the shelf behind the migrating deformation front and burial by rapidly deposited marine sediment. Varying degrees of reactivation of the older structures has occurred after the initial deformation, resulting in uplift, rotation and dissection of these structures. Deformation has been a continuous process during late Cenozoic time, as seismic mapping shows initiation of subsidence on one structural zone is accompanied by growth on a more seaward zone. The deformation is a response to persistent northwestward compression, and is a result of compression within the Yakutat block as the block moves northwestward with the Pacific plate and collides with insular Alaska.

Structural information on the seismic data from the Yakataga segment is limited to strata of late Cenozoic age, since only on a few segments of the seismic profiles is acoustic penetration through the thick Yakataga Formation achieved. Therefore the structure seen on the seismic data developed during the late Cenozoic, and extension of these structures into the underlying early to middle Tertiary strata is inferred. The Paleogene section present beneath the adjacent Yakutat shelf continues beneath the Yakataga shelf and may be present at drillable depths in some of the major structures.

\section{Middleton Segment}

The Middleton segment is bounded by the Kayak Island zone, the base of the slope, and Montague Island. The following discussion is from Bruns (1979); a structure map and seismic lines showing the character of the segment are shown in figures 19 and 20. The structure of the area southwest of Middleton Island is poorly known, as little seismic data has been acquired in this area. Structures on the Middleton segment include tightly folded and extensively faulted anticlines trending generally eastward and a shelf-edge structural high on which Middleton Island is located. The northeast-trending Kayak Island uplift and its offshore extension are also considered to be part of the Middleton segment since this feature has undergone significantly greater deformation than any of the Yakataga segment structures (figs. 19, 20; Bruns, 1979).

Kayak Is land marks a major zone of convergence and structural shortening. Late Cenozoic strata dip steeply or are overturned with tops facing toward the northwest, and the sequence shows imbrication into narrow slices by displacement on at least five large up-to-the-northwest reverse faults. Late Cenozoic strata do not include any major angular unconformities 


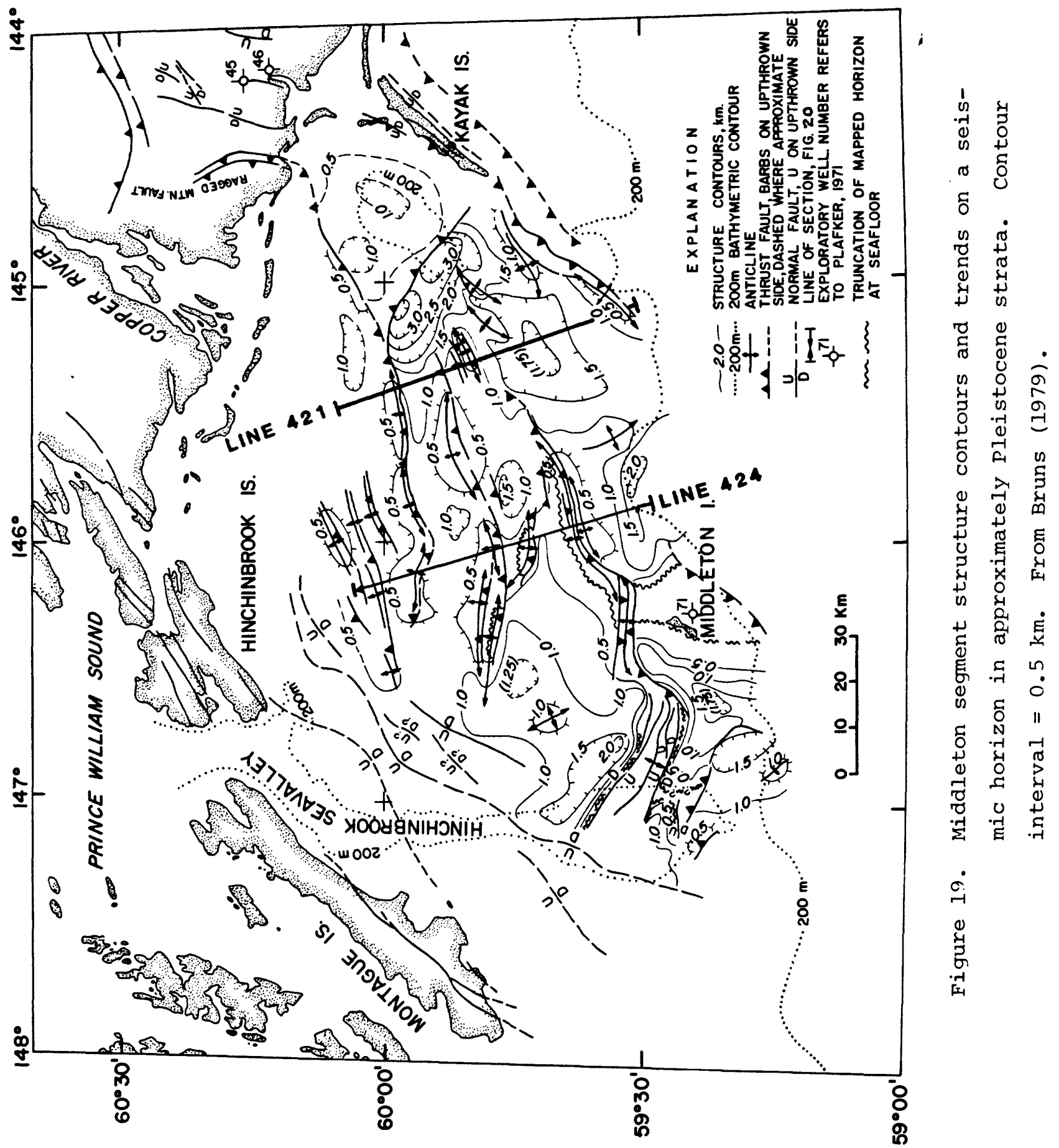




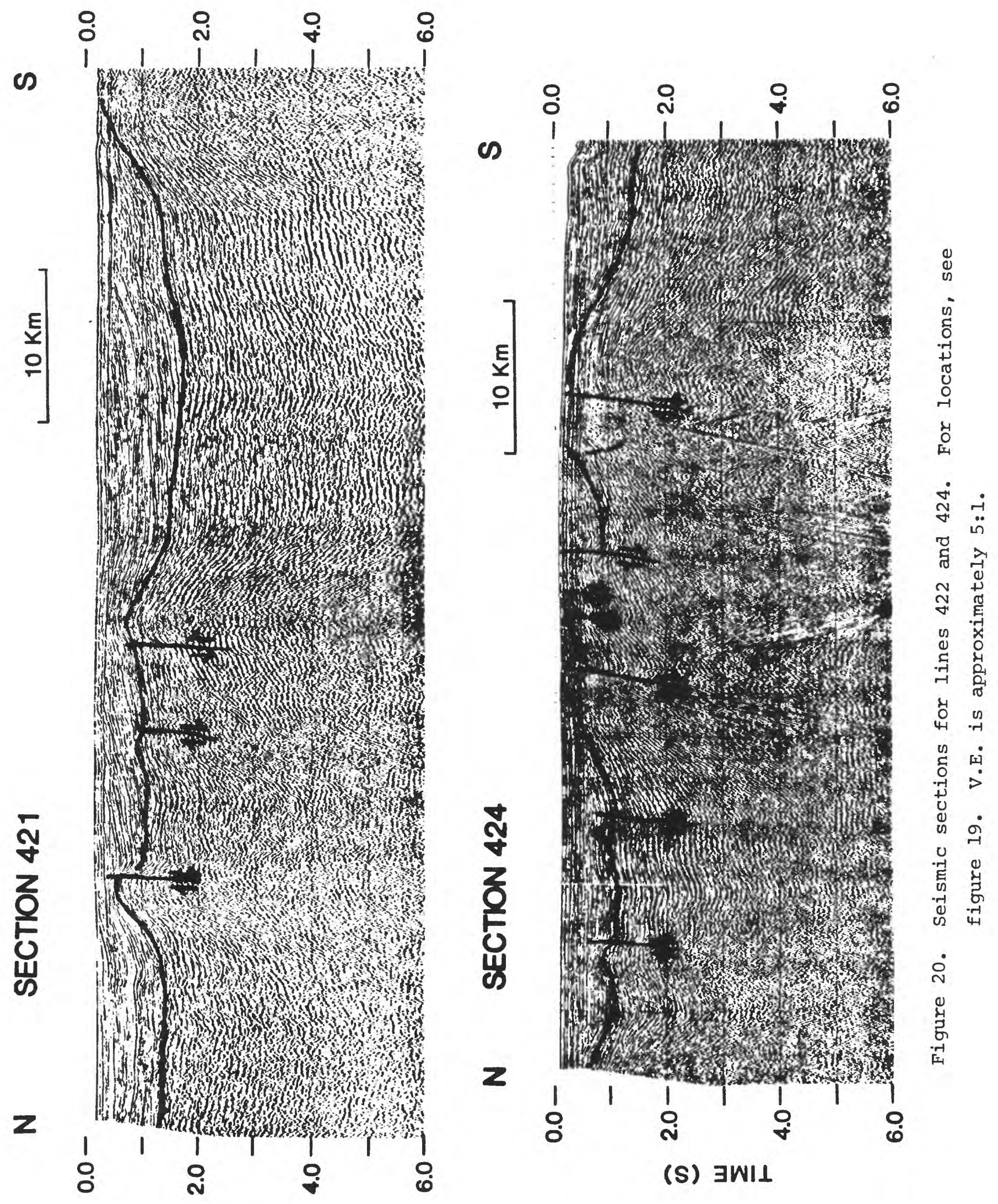

(S) $\exists W I \perp$ 
and appear to have been deformed essentially as a unit in post-middle Miocene time (Plafker, 1974). The island underwent significant uplift during the 1964 Alaska earthquake (Plafker, 1969).

On Middleton Island, approximately $1200 \mathrm{~m}$ of lower Pleistocene marine strata of the Yakataga Formation are exposed. Tilting, faulting and uplift of the shelf-edge high on which the island is located has occurred primarily during late Pleistocene and continues to be present (Plafker, 1969; Plafker and Addicott, 1976; Plafker and Rubin, 1978).

The general structural configuration of the continental shelf between Kayak and Middleton Island is shown by structural contours in strata of about early to middle Pleistocene age (fig. 19). The acoustic basement is shallow under parts of the shelf, mainly offshore of Montague Island, Hinchinbrook Island, and the Copper River. An unconformity is present on parts of several seismic lines in the central part of the Middleton shelf and near the shelf edge (fig. 20). Structural deformation below the unconformity is greater than in the overlying section. The unconformity is probably regional in extent.

The unconformity is similar to one observed on the Kodiak shelf, which is believed to be between highly deformed lower Tertiary rocks and gently deformed upper Cenozoic rocks (Fisher and von Huene, 1980). The section over the unconformity is approximately correlative with the Yakataga Formation. Seismic mapping shows that the upper Cenozoic section of the Middleton shelf is substantially thinner and more variable in thickness than the correlative section of the Yakataga shelf.

Structural highs underlying the Middleton shelf tend to be asymmetric and are bounded by major faults on the south. Uplift, folding, and faulting are more extreme on the Middleton shelf than in areas to the east, possibly approaching the degree of deformation mapped on Kayak Island. The crests of many of the highs appear to have been extensively eroded and truncated, probably exposing complexly deformed lower and middle Tertiary rocks at or near the seafloor. Numerous minor unconformities and growth features within the late Cenozoic section indicate deformation contemporaneous with deposition. The seismic data suggest that the structures west of Middleton Island developed prior to the uplift of Middleton Island.

Major faults other than those bounding anticlinal structures of the shelf include an extensive fault or fault zone beginning near the southern tip of Kayak Island and trending northwest to west across the shelf, and the offshore extension of the Ragged Mountain fault. Several probable faults in the western part of the shelf parallel Montague Island (fig. 19). Movement on these faults has brought probable lower Tertiary rocks near the surface, as indicated by the shallow acoustic basement underlying the area northwest of the faults.

\section{Pacific Ocean Basin}

Data in the Pacific Ocean basin consists of a few multichannel seismic lines, primarily near the base of the continental slope (fig. 4), and single channel data acquired during numerous cruises (von Huene and others, 1979). Sediment thickness near the base of the slope ranges from 3 to $4 \mathrm{~km}$ off southeastern Alaska, to $6 \mathrm{~km}$ off the Yakutat segment, and 2 to $3 \mathrm{~km}$ maximum 
along the Yakataga and Middleton segments. These thicknesses decrease rapidly seaward, and are less than about $2 \mathrm{~km}$ over much of the abyssal plain further than about $60 \mathrm{~km}$ from the base of the slope (von Huene and others, 1979; Ludwig and Houtz, 1979; Bruns and Schwab, in press; Bruns, 1982; Bruns, unpublished data).

The sediment at the base of the slope is most likely composed of turbidites, hemipelagic, and pelagic sediments. Coalescing turbidite fans along southeastern Alaskan form the thick sediment near the base of the slope. Sediment along the Yakutat, Yakataga, and Middleton segments is in part derived from prograding shelf sediments and in part from sediment that bypasses the shelf and slope along major submarine canyons.

\section{PETROLEUM GEOLOGY}

\section{Introduction}

Abundant oil and gas seeps first directed attention to the petroleum possibilities of the onshore northern Gulf of Alaska. One minor field at Katalla was discovered and produced between 1902 and 1933, 25 wells and core holes were drilled and abandoned onshore between 1954 and 1963, and one offshore well was drilled and abandoned in 1969 on state lands near Middleton Island. Available information on these wells is summarized in Plafker (1971), Plafker and others (1975), and Rau and others (1977). A stratigraphic test well was drilled on the ocs southwest of Cape Yakataga in 1975 (Table 2, fig. 15) but was terminated in Pleistocene strata at a depth of $1,570 \mathrm{~m}$ when drilling and weather problems significantly reduced the chances of penetrating potential objective horizons (Bolm and others, 1976). The first federal ocs oil and gas lease sale in Alaska, ocs lease sale no. 39, was held for the Yakataga shelf between Icy Bay and Kayak Island in 1976. Since the sale, ten offshore wildcat wells have been drilled and abandoned with no discoveries of commercial oil or gas. The location of these wells is shown on figure 15 and drilling information is summarized in Table 2. A second lease sale was held for the Yakutat shelf between Cross Sound and Icy Bay in OCS lease sale no. 55 in 1980, and a reoffering sale in 1981 (fig. 9). None of the lands leased during these sales have been drilled.

The following discussion on source rocks, thermal maturity, thermal analysis and reservoir potential, together with Tables 3 through 6 is abstracted primarily from Plafker and others (1980). The section on Lopatin calculations is from Bruns (1982). Data on onshore potential source rocks and on surface indications of petroleum were detailed by Plafker (1971) and Plafker and others (1975).

\section{Source and Reservoir Rock Characteristics}

Analysis of selected dredge samples from the continental slope indicates that rocks with favorable hydrocarbon source rock characteristics are present in the Eocene and oligocene strata. Organic matter in these samples is predomi nantly herbaceous, with subordinate amounts of amorphous kerogen. The total organic-carbon content of the analyzed samples ranges from 0.42 to 1.87 percent and averages greater than 1.0 percent (Table 3 ). This average is above the generally accepted minimum value of 0.5 percent for argillaceous hydrocarbon source rocks (Tissot and welte, 1978). The kerogen composition is 


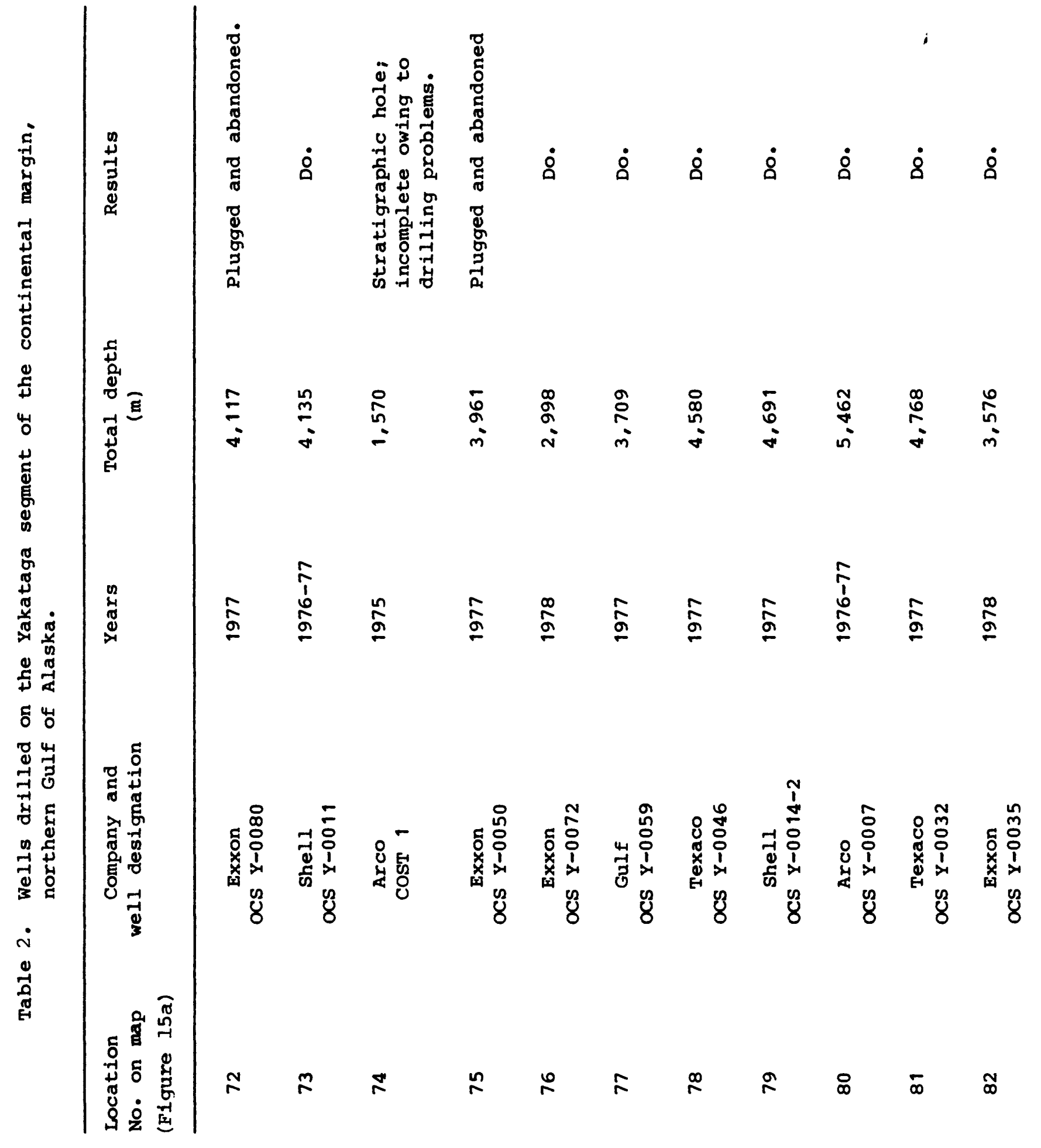


Table 3.--Organic carbon and visual kerogen assessment

[Analyses by Geochem Laboratories, Inc.]

\begin{tabular}{|c|c|c|c|c|c|c|c|}
\hline \multirow{2}{*}{$\begin{array}{l}\text { Geochem. } \\
\text { Sample No. }\end{array}$} & \multirow{2}{*}{$\begin{array}{l}\text { USAS } \\
\text { Sample No. }\end{array}$} & \multirow{2}{*}{$\begin{array}{l}\text { Total } \\
\text { organic } \\
\text { carbon } \\
\text { (WT \%) }\end{array}$} & \multicolumn{4}{|c|}{$\begin{array}{c}\text { Visual Kerogen (R-34) } \\
\text { \% Distribution }\end{array}$} & \multirow{2}{*}{$\begin{array}{l}\text { Thermal } \\
\text { Alteration } \\
\text { Index } \\
(R-35)\end{array}$} \\
\hline & & & Amorphous & Herbaceous & Humic & Inert & \\
\hline $\begin{array}{r}\text { R219-002 } \\
003 \\
004 \\
\end{array}$ & $\begin{array}{r}79-16 \mathrm{~F} \\
16 \mathrm{G} \\
16 \mathrm{H} \\
\end{array}$ & $\begin{array}{l}0.81 \\
1.46 \\
1.15 \\
\end{array}$ & $\begin{array}{l}0 \\
0 \\
0 \\
\end{array}$ & $\begin{array}{l}38 \\
40 \\
27 \\
\end{array}$ & $\begin{array}{l}31 \\
30 \\
36 \\
\end{array}$ & $\begin{array}{r}31 \\
30 \\
36 \\
\end{array}$ & $\begin{array}{l}2.9 \\
2.9 \\
3.1 \\
\end{array}$ \\
\hline $\begin{array}{r}\text { R201-008 } \\
009 \\
010 \\
\end{array}$ & $\begin{array}{r}78-2202 \\
2203 \\
2204 \\
\end{array}$ & $\begin{array}{l}0.84 \\
1.13 \\
\star\end{array}$ & $\begin{array}{r}0 \\
22 \\
0 \\
\end{array}$ & $\begin{array}{l}71 \\
44 \\
67 \\
\end{array}$ & $\begin{array}{l}29 \\
33 \\
33 \\
\end{array}$ & $\begin{array}{l}0 \\
0 \\
0 \\
\end{array}$ & $\begin{array}{l}2.4 \\
2.6 \\
2.5 \\
\end{array}$ \\
\hline 006 & $77-20 \mathrm{~B}$ & 1.03 & 0 & 20 & 40 & 40 & 3.6 \\
\hline 007 & $22 B$ & 1.45 & 0 & 83 & 17 & 0 & 2.3 \\
\hline $\begin{array}{r}R 219-026 \\
027 \\
\end{array}$ & $\begin{array}{r}79-42 D \\
42 E \\
\end{array}$ & $\begin{array}{l}1.24 \\
1.11 \\
\end{array}$ & $\begin{array}{r}11 \\
0 \\
\end{array}$ & $\begin{array}{l}56 \\
56 \\
\end{array}$ & $\begin{array}{l}33 \\
33 \\
\end{array}$ & $\begin{array}{r}0 \\
11 \\
\end{array}$ & $\begin{array}{l}2.3 \\
2.3 \\
\end{array}$ \\
\hline $\begin{array}{l}028 \\
029 \\
\end{array}$ & $\begin{array}{l}43 A \\
43 E \\
\end{array}$ & $\begin{array}{l}0.95 \\
1.22 \\
\end{array}$ & $\begin{array}{r}0 \\
20 \\
\end{array}$ & $\begin{array}{l}55 \\
60 \\
\end{array}$ & $\begin{array}{l}27 \\
10 \\
\end{array}$ & $\begin{array}{l}18 \\
10 \\
\end{array}$ & $\begin{array}{l}2.1 \\
2.1\end{array}$ \\
\hline 030 & $44 \mathrm{~A}$ & $\star$ & 9 & 45 & 36 & 9 & 1.6 \\
\hline $\begin{array}{l}018 \\
019 \\
020 \\
\end{array}$ & $\begin{array}{l}37 \mathrm{~A} \\
37 \mathrm{~B} \\
37 \mathrm{C} \\
\end{array}$ & $\begin{array}{l}1.51 \\
1.27 \\
1.22 \\
\end{array}$ & $\begin{array}{r}37 \\
0 \\
0 \\
\end{array}$ & $\begin{array}{l}63 \\
67 \\
56 \\
\end{array}$ & $\begin{array}{r}0 \\
33 \\
44 \\
\end{array}$ & $\begin{array}{l}0 \\
0 \\
0\end{array}$ & $\begin{array}{l}2.0 \\
2.3 \\
2.3 \\
\end{array}$ \\
\hline $\begin{array}{l}021 \\
022 \\
\end{array}$ & $\begin{array}{l}38 \mathrm{~A} \\
38 \mathrm{C} \\
\end{array}$ & $\begin{array}{l}1.51 \\
1.54 \\
\end{array}$ & $\begin{array}{l}31 \\
27 \\
\end{array}$ & $\begin{array}{l}54 \\
55 \\
\end{array}$ & $\begin{array}{r}15 \\
9 \\
\end{array}$ & $\begin{array}{l}0 \\
9 \\
\end{array}$ & $\begin{array}{l}2.2 \\
2.2 \\
\end{array}$ \\
\hline $\begin{array}{l}023 \\
024 \\
025 \\
\end{array}$ & $\begin{array}{l}39 D \\
39 F \\
39 G \\
\end{array}$ & $\begin{array}{l}1.57 \\
1.03 \\
1.10 \\
\end{array}$ & $\begin{array}{l}11 \\
50 \\
30 \\
\end{array}$ & $\begin{array}{l}67 \\
50 \\
50 \\
\end{array}$ & $\begin{array}{r}22 \\
0 \\
10 \\
\end{array}$ & $\begin{array}{r}0 \\
0 \\
10 \\
\end{array}$ & $\begin{array}{l}2.3 \\
2.1 \\
2.1 \\
\end{array}$ \\
\hline R201-011 & $78-43 F$ & $\star$ & 27 & 36 & 36 & 0 & 2.3 \\
\hline $\begin{array}{r}012 \\
013 \\
014 \\
\end{array}$ & $\begin{array}{l}44 D \\
44 \mathrm{E} \\
44 \mathrm{~F} \\
\end{array}$ & $\begin{array}{l}1.64 \\
1.49 \\
1.41 \\
\end{array}$ & $\begin{array}{r}0 \\
0 \\
22 \\
\end{array}$ & $\begin{array}{r}100 \\
83 \\
67 \\
\end{array}$ & $\begin{array}{r}0 \\
17 \\
11 \\
\end{array}$ & $\begin{array}{l}0 \\
0 \\
0 \\
\end{array}$ & $\begin{array}{l}1.9 \\
1.9 \\
1.9 \\
\end{array}$ \\
\hline $\begin{array}{r}\text { R219-015 } \\
016 \\
017 \\
\end{array}$ & $\begin{array}{r}79-36 \mathrm{~A} \\
36 \mathrm{C} \\
360 \\
\end{array}$ & $\begin{array}{l}1.34 \\
1.40 \\
1.86 \\
\end{array}$ & $\begin{array}{l}40 \\
30 \\
27 \\
\end{array}$ & $\begin{array}{l}60 \\
60 \\
55 \\
\end{array}$ & $\begin{array}{r}0 \\
10 \\
9 \\
\end{array}$ & $\begin{array}{l}0 \\
0 \\
9 \\
\end{array}$ & $\begin{array}{l}2.2 \\
2.1 \\
2.1 \\
\end{array}$ \\
\hline R201-002 & $77-11 B$ & 1.12 & 0 & 86 & 14 & 0 & 2.1 \\
\hline 001 & $10 B$ & $\star$ & 0 & 71 & 29 & 0 & 2.1 \\
\hline $\begin{array}{r}\text { R219-011 } \\
012 \\
013 \\
\end{array}$ & $\begin{array}{r}79-24 A \\
24 B \\
24 C \\
\end{array}$ & $\begin{array}{l}1.59 \\
1.42 \\
1.53 \\
\end{array}$ & $\begin{array}{l}0 \\
11 \\
10 \\
\end{array}$ & $\begin{array}{l}75 \\
56 \\
50 \\
\end{array}$ & $\begin{array}{l}25 \\
33 \\
30 \\
\end{array}$ & $\begin{array}{r}0 \\
0 \\
10 \\
\end{array}$ & $\begin{array}{l}1.8 \\
1.9 \\
2.1 \\
\end{array}$ \\
\hline $\begin{array}{r}R 201-003 \\
004 \\
\end{array}$ & $\begin{array}{r}77-17 \mathrm{~B} \\
17 \mathrm{E} \\
\end{array}$ & $\begin{array}{l}1.22 \\
0.63 \\
\end{array}$ & $\begin{array}{r}0 \\
11 \\
\end{array}$ & $\begin{array}{l}83 \\
56 \\
\end{array}$ & $\begin{array}{l}17 \\
33 \\
\end{array}$ & $\begin{array}{l}0 \\
0 \\
\end{array}$ & $\begin{array}{l}2.2 \\
1.2 \\
\end{array}$ \\
\hline 005 & $18 \mathrm{~A}$ & 0.56 & 0 & 56 & 44 & 0 & 1.2 \\
\hline R219-006 & $79-20 B$ & 0.67 & 0 & 50 & 40 & 10 & 2.3 \\
\hline 009 & $21 E$ & 0.65 & 0 & 44 & 44 & 11 & 2.3 \\
\hline 005 & $18 A$ & 0.54 & 0 & 22 & 33 & 44 & 4.0 \\
\hline
\end{tabular}


of a type that can generate both liquid hydrocarbons and gas (Plafker and Claypool, 1979; Plafker and others, 1980).

Petroleum from seeps at Wingham Island and Samovar Hills, and extractable hydrocarbons in the dredge samples from the Yakutat slope (sample 44; Plafker and Claypool, 1979; Plafker and others, 1980) are all similar in composition. The hydrocarbons are high gravity, paraffin-base, low-sulfur oils, and are probably derived from the same type kerogen. The seeps and dredge sampled are all from an organic rich, neritic to bathyal marine sedimentary sequence of early to middle Eocene age (Plafker, unpublished data). These rocks were not sampled in the Middleton Island well. Therefore, this sequence appears to be confined to the allochthonous Yakutat block and does not extend westward into the Middleton segment or Kodiak shelf. The upper Cenozoic strata (Yakataga Formation equivalent) has few indications of favorable source rocks.

No data are available on source rock potential for the southeast Alaska segment, or for strata at the base of the slope between Cross Sound and Middleton segment.

Thermal Maturity

Indicators of thermal maturity generally show that the dredged samples from the Eocene and oligocene strata are immature to marginally mature (Plafker and Claypool, 1979; Plafker and others, 1980). Oil generation begins at a thermal alteration index (TAI) of 2 and a vitrinite reflectance value (Ro) of about 0.6 percent. Peak oil generation ends at a TAI of around 3 and vitrinite reflectance of 1.35 percent (Dow, 1977, 1979; Tissot and Welte, 1978). Vitrinite reflectance values for dredge samples from the Eocene and oligocene strata are generally within the range of 0.3 to 0.6 percent; only a few samples are near or greater than 0.6 percent (Table 4). The TAI for these samples ranges from 1.2 to 2.3 , with most samples around 1.9 to 2.1 (table 3). Thus, these rocks are immature to marginally mature for oil. These rocks should, however, be more mature beneath the continental shelf because of greater depth of burial. Vitrinite reflectance values from probable Paleocene strata dredged south of Icy Bay range from about 0.4 to 3.0 percent, and TAI values from 2.3 to 3.6 indicating that these rocks are mature to overmature for oil.

Thermal Analysis of Dredged Rocks

The results of thermal analysis by Rock-Eval or MP-3 pyrolysis, summarized in Table 5, indicate that the dredged samples have adequate organic matter content but not of the chemical type which generates liquid hydrocarbons. These data suggest that the rocks are immature to marginally mature for oil.

The hydrocarbon-generating capacity of the rocks is indicated in a semiquantitative fashion by the total hydrocarbon yield or genetic potential $\left(S_{1}+S_{2}\right.$, in ppm or kilogram of hydrocarbon per metric ton of rock). The values shown for the dredged samples on Table 5 range from 50 to 2,270 ppm. All but the samples from locality 23 are less than the $2,000 \mathrm{ppm}$ yield considered to be a minimum for oil source rocks but in the range of yield for rocks with some potential for gas generation (Tissot and Welte, 1978). 
Table 4.--Vitrinite reflectance summary (R-33)

[Analyses by Geochem Laboratories, Inc.]

\begin{tabular}{|c|c|c|c|c|c|c|}
\hline \multirow{2}{*}{$\begin{array}{l}\text { Map } \\
\text { No. }\end{array}$} & \multirow{2}{*}{$\begin{array}{l}\text { Geochem. } \\
\text { Sample No. }\end{array}$} & \multirow{2}{*}{$\begin{array}{c}\text { USGS } \\
\text { Sample No. }\end{array}$} & \multirow{2}{*}{$\begin{array}{l}\text { Number of } \\
\text { Readings }\end{array}$} & \multicolumn{3}{|c|}{ Reflectance $\left(\% R_{0}\right)$} \\
\hline & & & & Minimum & Maximum & Average \\
\hline 1 & $\begin{array}{r}\text { R219-002 } \\
003 \\
004 \\
\end{array}$ & $\begin{array}{r}79-16 \mathrm{~F} \\
166 \\
16 \mathrm{H} \\
\end{array}$ & $\begin{array}{l}50 \\
50 \\
50 \\
\end{array}$ & $\begin{array}{l}1.25 \\
1.92 \\
1.90 \\
\end{array}$ & $\begin{array}{l}1.57 \\
2.29 \\
2.37 \\
\end{array}$ & $\begin{array}{l}1.45 \\
2.12 \\
2.16 \\
\end{array}$ \\
\hline 4 & $\begin{array}{r}\text { R201-008 } \\
009 \\
010\end{array}$ & $\begin{array}{r}78-22 \mathrm{D} 2 \\
22 \mathrm{D} 3 \\
22 \mathrm{D} 4\end{array}$ & $\begin{array}{l}50 \\
9 \text { (Pop. 1) } \\
41 \text { (Pop. 2) } \\
4 \text { (Pop. 1) } \\
45 \text { (Pop. 2) } \\
1 \text { (Pop. 3) }\end{array}$ & $\begin{array}{r}0.53 \\
.37 \\
.79 \\
.45 \\
.86 \\
1.20 \\
\end{array}$ & $\begin{array}{r}0.67 \\
.59 \\
1.03 \\
.73 \\
1.09 \\
1.20 \\
\end{array}$ & $\begin{array}{r}0.60 \\
.49 \\
.90 \\
.59 \\
.97 \\
1.20 \\
\end{array}$ \\
\hline 6 & 006 & $77-20 B$ & $\begin{array}{r}4 \text { (Pop. 1) } \\
50 \text { (Pop. 2) }\end{array}$ & $\begin{array}{l}0.49 \\
2.90\end{array}$ & $\begin{array}{l}0.59 \\
3.64\end{array}$ & $\begin{array}{l}0.54 \\
3.32\end{array}$ \\
\hline 8 & 007 & $22 B$ & 50 & 0.37 & 0.49 & 0.43 \\
\hline 9 & $\begin{array}{r}R 219-026 \\
027\end{array}$ & $\begin{array}{r}79-42 D \\
42 E\end{array}$ & $\begin{array}{l}50 \\
50\end{array}$ & $\begin{array}{r}0.37 \\
.38\end{array}$ & $\begin{array}{r}0.54 \\
.56\end{array}$ & $\begin{array}{r}0.46 \\
.47\end{array}$ \\
\hline 10 & $\begin{array}{l}028 \\
029 \\
\end{array}$ & $\begin{array}{l}43 A \\
43 E \\
\end{array}$ & $\begin{array}{l}40 \\
50 \\
\end{array}$ & $\begin{array}{r}0.34 \\
.34\end{array}$ & $\begin{array}{r}0.53 \\
.47 \\
\end{array}$ & $\begin{array}{r}0.44 \\
.40 \\
\end{array}$ \\
\hline 11 & 030 & $44 A$ & 39 & 0.26 & 0.41 & 0.34 \\
\hline 12 & $\begin{array}{l}018 \\
019 \\
020\end{array}$ & $\begin{array}{l}37 A \\
37 B \\
37 C\end{array}$ & $\begin{array}{l}50 \\
50 \\
50\end{array}$ & $\begin{array}{l}0.31 \\
.41 \\
.47\end{array}$ & $\begin{array}{l}0.46 \\
.67 \\
.57\end{array}$ & $\begin{array}{r}0.37 \\
.50 \\
.48\end{array}$ \\
\hline 13 & $\begin{array}{l}021 \\
022 \\
\end{array}$ & $\begin{array}{l}38 \mathrm{~A} \\
38 \mathrm{C} \\
\end{array}$ & $\begin{array}{l}50 \\
50 \\
\end{array}$ & $\begin{array}{r}0.36 \\
.35 \\
\end{array}$ & $\begin{array}{r}0.55 \\
.54 \\
\end{array}$ & $\begin{array}{r}0.46 \\
.44 \\
\end{array}$ \\
\hline 14 & $\begin{array}{l}023 \\
024 \\
025 \\
\end{array}$ & $\begin{array}{l}39 D \\
39 F \\
39 G \\
\end{array}$ & $\begin{array}{l}50 \\
50 \\
50 \\
\end{array}$ & $\begin{array}{r}0.53 \\
.33 \\
.38 \\
\end{array}$ & $\begin{array}{r}0.69 \\
.53 \\
.58\end{array}$ & $\begin{array}{r}0.61 \\
.46 \\
.50 \\
\end{array}$ \\
\hline 15 & R201-011 & $78-43 F$ & $\begin{array}{r}2 \text { (Pop. 1) } \\
50 \text { (Pop. 2) }\end{array}$ & $\begin{array}{r}0.27 \\
.43\end{array}$ & $\begin{array}{l}.31 \\
.63\end{array}$ & $\begin{array}{l}.29 \\
.55 \\
\end{array}$ \\
\hline 16 & $\begin{array}{l}012 \\
013 \\
014 \\
\end{array}$ & $\begin{array}{l}44 D \\
44 E \\
44 F \\
\end{array}$ & $\begin{array}{l}46 \\
50 \\
25 \\
\end{array}$ & $\begin{array}{r}0.23 \\
.21 \\
.21 \\
\end{array}$ & $\begin{array}{l}.40 \\
.42 \\
.38 \\
\end{array}$ & $\begin{array}{l}.32 \\
.33 \\
.29 \\
\end{array}$ \\
\hline 23 & $\begin{array}{r}219-015 \\
016 \\
017 \\
\end{array}$ & $\begin{array}{r}9-36 \mathrm{~A} \\
36 \mathrm{C} \\
36 \mathrm{D} \\
\end{array}$ & $\begin{array}{l}50 \\
50 \\
28 \\
\end{array}$ & $\begin{array}{r}0.27 \\
.28 \\
.29 \\
\end{array}$ & $\begin{array}{r}0.43 \\
.41 \\
.43 \\
\end{array}$ & $\begin{array}{r}0.32 \\
.33 \\
.36 \\
\end{array}$ \\
\hline 27 & $R 201-002$ & $77-11 B$ & 50 & 0.31 & 0.48 & 0.39 \\
\hline 28 & 001 & $10 B$ & 50 & 0.40 & 0.60 & 0.52 \\
\hline 29 & $\begin{array}{r}\text { R219-011 } \\
012 \\
013\end{array}$ & $\begin{array}{r}79-24 A \\
24 B \\
24 C \\
\end{array}$ & $\begin{array}{l}50 \\
50 \\
50\end{array}$ & $\begin{array}{r}0.29 \\
.27 \\
.27\end{array}$ & $\begin{array}{l}0.40 \\
.41 \\
.42\end{array}$ & $\begin{array}{r}0.33 \\
.33 \\
.34 \\
\end{array}$ \\
\hline 30 & $\begin{array}{r}\text { R201-003 } \\
004\end{array}$ & $\begin{array}{r}77-17 \mathrm{~B} \\
17 \mathrm{E}\end{array}$ & $\begin{array}{l}50 \\
20\end{array}$ & $\begin{array}{r}0.34 \\
.18\end{array}$ & $\begin{array}{r}0.50 \\
.29\end{array}$ & $\begin{array}{r}0.43 \\
.22 \\
\end{array}$ \\
\hline 31 & $R 201-005$ & $18 \mathrm{~A}$ & 46 & .21 & .36 & .25 \\
\hline 32 & R219-006 & $79-20 B$ & 50 & 0.54 & 0.75 & 0.61 \\
\hline 33 & 009 & $21 E$ & 50 & 0.49 & 0.67 & 0.57 \\
\hline 35 & 005 & $18 A$ & 50 & 4.16 & 4.95 & 4.56 \\
\hline
\end{tabular}




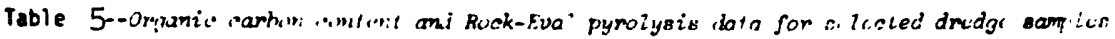

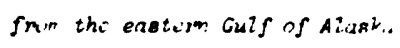

[n.a. = no analysis; n.d. = no determination]

\begin{tabular}{|c|c|c|c|c|c|c|c|c|c|c|}
\hline $\begin{array}{c}\text { Map } \\
\text { number } \\
\text { (fig. 1) }\end{array}$ & $\begin{array}{l}\text { Sample } \\
\text { number }\end{array}$ & $\begin{array}{l}c-1 / \\
\text { (per- } \\
\text { cent) }\end{array}$ & $\begin{array}{c}s_{1}^{2} f \\
(m g / g)\end{array}$ & $\begin{array}{c}5: / \\
(\mathrm{mg} / \mathrm{g})\end{array}$ & $\begin{array}{c}\mathrm{S}_{3}{ }^{2} \mathrm{I} \\
(\mathrm{mg} / \mathrm{g})\end{array}$ & $\begin{array}{c}T\left(S_{2}\right)^{2} / \\
\left({ }^{\circ} \mathrm{C}\right)\end{array}$ & $\begin{array}{l}\text { Genetic } \\
\text { Potential } \\
S_{1}+S_{2} \\
\text { (ppm) }\end{array}$ & $\begin{array}{c}\text { Hydrogen } \\
\text { Index } \\
S_{2} / C \\
(\operatorname{mgHC} / g C)\end{array}$ & $\begin{array}{c}\text { Oxygen } \\
\text { Index } \\
\mathrm{S}_{3} / \mathrm{C} \\
\left(\mathrm{mg} \mathrm{CO}_{2} / g C\right)\end{array}$ & $\begin{array}{l}\text { Transforma- } \\
\text { tion Katio } \\
S_{1} / S_{1}+S_{i}\end{array}$ \\
\hline 1 & $7 y-16 F$ & 0.66 & 0.09 & 0 & 0.78 & 0 & 90 & 0 & 119 & 1.0 \\
\hline 1 & $19-16 G T$ & 1.16 & 0.06 & .004 & 0.27 & 546 & 60 & 0.4 & 23 & 0.43 \\
\hline 1 & $7 y-16 \mathrm{H}$ & 1.04 & 0.12 & 0 & U. 54 & 0 & 120 & 0 & $b 2$ & 1.0 \\
\hline 4 & $78-2201$ & 0.75 & 0.104 & 0.375 & 0.69 & 445 & 479 & 50 & 92 & 0.22 \\
\hline 4 & $78-2202$ & 0.84 & 0.099 & 0.415 & 0.72 & 442 & 514 & 49 & 87 & 0.19 \\
\hline 4 & $78-2203$ & 1.13 & 0.145 & 0.816 & 0.14 & 439 & 961 & 72 & 12 & 0.15 \\
\hline 6 & $77-20 \mathrm{~B}$ & 1.03 & 0.030 & 0.100 & n.a. & n.d. & 130 & 13 & n.a. & 0.23 \\
\hline 8 & $77-228$ & 1.45 & 0.017 & 1.513 & n.e. & 426 & 1,530 & 105 & $n \cdot a$. & 0.01 \\
\hline 9 & $70-420$ & 1.44 & 0.08 & 0.60 & 0.43 & 437 & 680 & 42 & 30 & 0.12 \\
\hline 9 & $79-42 E$ & 1.21 & 0.09 & 0.63 & 0.26 & 432 & 720 & 52 & 22 & 0.12 \\
\hline 10 & $79-43 A$ & 1.37 & 0.04 & 0.41 & 0.98 & 429 & 450 & 30 & 71 & 0.09 \\
\hline 10 & $79-43 E$ & 1.37 & 0.04 & 0.90 & 0.64 & 425 & 940 & 66 & 47 & 0.04 \\
\hline 11 & $79-44 A$ & 0.80 & 0.15 & 0.23 & 0.85 & 424 & 380 & 26 & 97 & 0.40 \\
\hline 12 & $79-37 A$ & 1.11 & 0.06 & 0.88 & 1.02 & 436 & 940 & 79 & 91 & 0.07 \\
\hline 12 & $79-378$ & 1.10 & 0.03 & 0.27 & 0.91 & 445 & 300 & 24 & 83 & 0.11 \\
\hline 12 & $79-37 C$ & 1.24 & 0.04 & 0.66 & 1.13 & 439 & 700 & 53 & 91 & 0.06 \\
\hline 13 & $79-38 A$ & 1.51 & 0.07 & 0.90 & 1.21 & 429 & 970 & 60 & 80 & 0.07 \\
\hline 13 & $79-38 C$ & 1.10 & 0.04 & 0.28 & 1.35 & 429 & 320 & 25 & 123 & 0.13 \\
\hline 14 & $79-390$ & 1.67 & 0.05 & 0.59 & 0.38 & 442 & 640 & 35 & 22 & 0.07 \\
\hline 14 & $79-39 F$ & 1.03 & 0.15 & 0.69 & 0.86 & 447 & 840 & 67 & 83 & 0.17 \\
\hline 14 & $79 \cdot 396$ & 0.82 & 0.11 & 0.24 & 0.72 & 452 & 350 & 29 & 87 & 0.31 \\
\hline 16 & $78-440$ & 1.64 & 0.034 & 1.42 & 2.03 & 421 & 1,452 & 86 & 123 & 0.02 \\
\hline 16 & $78-44 E$ & 1.49 & 0.189 & 1.16 & 2.63 & 425 & 1,350 & 78 & 176 & 0.14 \\
\hline 16 & $78-44 F$ & 1.41 & 0.140 & 0.943 & 3.11 & 421 & 1,080 & 67 & 221 & 0.13 \\
\hline 22 & $79-350$ & 0.68 & 0.06 & 0.22 & 0.39 & 426 & 280 & 32 & 57 & 0.23 \\
\hline 23 & $79-36 A$ & 1.74 & 0.08 & 1.30 & 2.54 & 435 & 1,380 & 75 & 146 & 0.06 \\
\hline 23 & $79-36 C$ & 1.87 & 0.11 & 1.98 & 2.61 & 432 & 2,090 & 106 & 140 & 0.05 \\
\hline 23 & $79-360$ & 1.61 & 0.12 & 2.15 & 2.35 & 428 & 2,270 & 133 & 146 & 0.05 \\
\hline 27 & $77-118$ & 1.12 & 0.035 & 1.405 & n.a. & 408 & 1,440 & 128 & n.a. & 0.02 \\
\hline 29 & $79-24 A$ & 1.73 & 0.14 & 1.39 & 1.93 & 429 & 1,530 & 80 & 112 & 0.09 \\
\hline 29 & $79-24 B$ & 1.78 & 0.14 & 1.38 & 1.73 & 430 & 1,520 & 78 & 97 & 0.09 \\
\hline 29 & $79-24 C$ & 1.76 & 0.05 & 1.10 & 1.73 & 428 & 1.150 & 62 & 98 & 0.05 \\
\hline 30 & $77-178$ & 1.22 & $0^{\circ}$ & 0.810 & n.a. & 420 & 810 & 66 & n.a. & 0 \\
\hline 30 & $77-17 c$ & 0.71 & 0.016 & 0.454 & n.a. & 420 & 470 & 66 & n.a. & 0.03 \\
\hline 30 & $77-17 E$ & 0.63 & 0.048 & 0.232 & n.a. & n.d. & 280 & 44 & n.a. & 0.17 \\
\hline 31 & $77-18 A$ & 0.56 & 0.036 & 0.314 & n.a. & 392 & 350 & 62 & n.a. & 0.10 \\
\hline 32 & $79-2 O B$ & 0.75 & 0.03 & 0.15 & 0.50 & 438 & 180 & 20 & 66 & 0.14 \\
\hline 32 & $79-20 E$ & 0.41 & 0.09 & 0.04 & 0.44 & 436 & 130 & 10 & 106 & 0.70 \\
\hline 33 & $79-210$ & 0.61 & 0.03 & 0.07 & 0.51 & 440 & 100 & 12 & 83 & 0.32 \\
\hline 33 & $79-21 E$ & 0.63 & 0.04 & 0.09 & 0.34 & 441 & 130 & 15 & 54 & 0.32 \\
\hline 33 & $79-21 F$ & 0.42 & 0.06 & 0.07 & 1.27 & 428 & 130 & 16 & 303 & 0.47 \\
\hline 35 & $79-18 A$ & 0.75 & 0.05 & 0 & 0.20 & 0 & 50 & 0 & 26 & 1.0 \\
\hline
\end{tabular}

$1 /$ Total organic carbon analyses by Rinehart Laboratories, Arvada, Colorado.

$2 /$ Thermal analyses by T. Daws and J. P. Baysinger. U.S. Geological Survey. 
The type of organic matter in the rocks is indicated from Rock-Eval pyrolysis by the hydrogen and oxygen indices, which are the pyrolytic hydrocarbon yield $\left(S_{2}\right)$ and the pyrolytic organic $\mathrm{CO}_{2}$ yield $\left(\mathrm{S}_{3}\right)$, respectively, each normalized by organic carbon content. Hydrogen indices for the analyzed 1977 samples, and both hydrogen and oxygen indices for the 1978 and 1979 samples are calculated and shown in Table 5. The generally low hydrogen index suggests that the organic matter in the dredged samples is not the type that would generate mainly liquid hydrocarbons.

Thermal maturity is interpreted from the temperature of maximum pyrolysis yield $T\left(S_{2}\right)$ and the transformation ratio $\left(S_{1} / S_{2}+S_{2}\right)$ given in Table 5 . In general, the transition from immature to mature with respect to oil generation is indicated by $T\left(S_{2}\right)$ values of about $440^{\circ} \mathrm{C}$, and transformation ratios of 0.1 (Tissot and Welte, 1978). Based on these criteria, the dredge samples east of Alsek Canyon and west of Yakutat Valley give consistent indications of marginal thermal maturity. This agrees closely with the independent results of visual kerogen assessment and vitrinite reflectance analysis.

\section{Calculated Thermal Maturity of Paleogene Rocks}

The Paleogene sedimentary strata dredged from the Yakutat segment slope (Plafker and others, 1980) contain potential source rocks that are generally immature to marginally mature in the dredge samples. The method of Lopatin (Waples, 1980) can be used to estimate the maturity of strata beneath the shelf (Bruns, 1982). The method requires estimates of burial history and geothermal gradient in the area of interest. Bruns (1982) gives estimates of burial history, based on seismic mapping of strata below the shelf, and estimates a geothermal gradient that may range from less than $20^{\circ} \mathrm{C} / \mathrm{km}$ to about $30^{\circ} \mathrm{C} / \mathrm{km}$ based on temperatures measured in wells. For a geothermal gradient of $25^{\circ} \mathrm{c} / \mathrm{km}$, the calculated depth to strata mature enough to generate oil varies from about 3.5 to $5 \mathrm{~km}$, and averages about $4.5 \mathrm{~km}$ basinwide. For geothermal gradients of $20^{\circ} \mathrm{c} / \mathrm{km}$ and $30^{\circ} \mathrm{c} / \mathrm{km}$, the average depth is around 5.5 $\mathrm{km}$ and $3.8 \mathrm{~km}$ respectively. About 358 of the total sedimentary sequence is buried deeper than $4 \mathrm{~km}$ and about 208 below $5 \mathrm{~km}$. In each case these rocks would be almost all of Paleogene age. Estimates of total sedimentary rock volume and Paleogene sedimentary rock volume then indicate about 258 to 708 of the Paleogene sedimentary strata below the continental shelf could be mature e nough to generate oil, depending on the geothermal gradient (Bruns, 1982). The above calculations are approximate, since none of the parameters usad are known accurately. The value of the estimates is that they indicate the strong possibility that a large part of the Paleogene section may be mature enough to generate oil and gas below the continental shelf.

\section{Reservoir Rocks}

Tertiary sandstones are the only potential reservoir rocks with primary porosity and permeability. The reservoir characteristics of the Tertiary sandstones from the outcrop and wells have been presented by winkler and others (1976) and by Plafker and others (1975). Data on dredge haul samples are given by Plafker and others (1980); and are summarized below and in Table 6.

Outcrop and dredge haul samples from the continental slope are compositionally and texturally immature. Even the best-sorted sandstones 
Table $\dot{6} .--$ Sandstone reservoir characteristics

\begin{tabular}{|c|c|c|c|c|}
\hline $\begin{array}{c}\text { No. } \\
\text { (Fig. 1) }\end{array}$ & $\begin{array}{l}\text { USGS } \\
\text { Sample } \\
\text { Number }\end{array}$ & $\begin{array}{c}\text { Liquid } \\
\text { Permeability } \\
\text { (md) }\end{array}$ & $\begin{array}{c}\text { Porosity } \\
(\%)\end{array}$ & $\begin{array}{c}\text { Grain Density } \\
\text { ( }(0)\end{array}$ \\
\hline 5 & $79-24 E$ & 4.0 & 14.9 & 2.68 \\
\hline 6 & $77-20 C$ & .0006 & 12.0 & 2.68 \\
\hline \multirow[t]{2}{*}{7} & $78-2105$ & .01 & 6.3 & 2.67 \\
\hline & 2104 & .15 & 5.7 & 2.68 \\
\hline 8 & $77-22 A$ & .006 & 11.7 & 2.66 \\
\hline 9 & $79-42 B$ & 3.1 & 21.7 & 2.68 \\
\hline 10 & $79-43 c$ & 1.2 & 16.2 & 2.71 \\
\hline 12 & $79-37 F$ & 1.3 & 14.4 & 2.69 \\
\hline \multirow[t]{2}{*}{16} & $78-44 A$ & 26.0 & 31.3 & 2.59 \\
\hline & $44 B$ & 2.9 & 31.8 & 2.53 \\
\hline 27 & $77-11 c$ & .008 & 8.1 & 2.63 \\
\hline 28 & $77-10 c$ & 35.9 & 23.8 & 2.63 \\
\hline 29 & $79-24 E$ & 2.8 & 31.6 & 2.67 \\
\hline 30 & $77-17 A$ & .51 & 18.1 & 2.63 \\
\hline 39 & $78-14 B$ & .14 & 8.8 & 2.69 \\
\hline
\end{tabular}


appear to have poor reservoir characteristics because they are greatly compacted and tightly cemented with authigenic silica, zeolites, and carbonates.

Better sorted and less indurated sandstone is present locally in the middle and upper Tertiary sequences, but most of the outcrop samples also have fairly low porosity and permeability, mainly because of a fine-grained matrix of rock flour and primary and authigenic phyllosilicates. A few samples' of dredged sandstones with permeablities and porosities sufficient to serve as reservoir rocks were recovered from the Eocene and Oligocene rocks. In these rocks the permeability and porosity appear to be largely secondary.

Most of the outcropping Yakataga sandstone that has been examined microscopically shows interstices effectively plugged by deformed detrital lithic fragments that comprise an average of 23 percent of the sand grains. Locally, however, selected strandline sandstones have been found in outcrops of the uppermost Yakataga Formation of the eastern Yakataga district that have porosities over 20 percent and permeabilities of a few hundred millidarcies (Anon., 1976).

The source of the Neogene clastic sediments in the basin was primarily in the north and northeast. Consequently, average grain size and sorting of the sandstones normally would tend to decrease offshore with a concomitant reduction in porosity and permeablility. However, sorted sands in large quantity could have been transported well out into the basin by turbidity currents, or unsorted sands may have been reworked along the flanks of structural highs that might have been elevated to or near sea level sometime after deposition within the basin.

No data are available on reservoir rock potential of strata off southeast Alaska or along the base of the slope. Since these strata are likely deposited in large turbidite fan complexes, well sorted sands may be present within the sedimentary sequence, similar to sand drilled off Kodiak Island on Leg 18 of the Deep Sea Drilling Program (von Huene and others, 1973; 1976).

\section{Structural and Stratigraphic Traps}

\section{Southeastern Alaska}

No potential hydrocarbon traps are known on the shelf of the southeast Alaska segment. The large anticlinal folds below the slope between Dixon Entrance and Sitka could serve as traps (fig. 8). Too few data are available to determine the extent or possible closure of these structures, or the possibility of structural or stratigraphic traps elsewhere.

\section{Yakutat segment}

Seismic data show only one late Cenozoic fold on the Yakutat shelf; this fold is just offshore of the Dangerous River and trends onshore to the west. This structure may form a drill target in state lands nearshore and onshore, and was likely tested by three wells drilled near Yakutat in 1957-1959. At least one large, gentle anticline is present in the early Paleogene strata of the shelf (fig. 13). The extent of this structure and the presence of some smaller, similar structures is inferred from the blocks leased in ocs lease 
sale no. 55 (fig. 9). This structure developed prior to about late oligocene time and could serve as an effective trap. Additional structures may be present but not seen in the widely spaced seismic data (Bruns, 1982).

The Dangerous River zone may provide possibilities for stratigraphic and structural traps. Paleogene strata lap onto the acoustic basement and may, in part, be faulted against pre-Tertiary strata along the Dangerous River zone. These potential traps generally are updip from the basin axis, and could trap hydrocarbons migrating out of the basin lows. The Dangerous River zone may have formed the Paleogene basin margin. This zone may therefore create enhanced opportunities for the presence of coarse clastic rocks, up-dip stratigraphic traps, possible Eocene carbonate reefs, and fault seals along the zone. In addition, the overlying late Cenozoic section could provide a seal over the Paleogene strata.

The uplift of the Fairweather Ground high is unlikely to provide significant trap possibilities, since Tertiary strata around the high generally outcrop at the seafloor, and apparently no effective seal is present. Possible exceptions to this may occur on the west end of the high along the Dangerous River zone.

Several large anticlines at the base of the slope off Fairweather Ground (fig. 14) provide trap potential for hydrocarbons that might be generated within the thick sedimentary sequence present at the base of the slope. Too few data are available to determine the extent or closure of these structures.

Yakataga Segment

The numerous large anticlines with demonstrated closure provide traps under the Yakataga shelf and continental slope (figs. 16-18). In addition, petroleum seeps occur on adjacent onshore structures, some of wich trend into the offshore. The structures beneath the continental slope are untested. Recent drilling activity tested the largest offshore structures on the continental shelf and failed to find commercial hydrocarbon accumulations. The upper Cenozoic strata in these structures has poor source and reservoir characteristics. Therefore these rocks have little potential to generate hydrocarbons or provide reservoirs for hydrocarbons that may migrate from the underlying Paleogene strata. Most of the wells did not penetrate through the upper Cenozoic strata. In the wells wich reached the principal target section, of Oligocene and Miocene age, the section turned out to have inadequate source properties and few potential reservoirs, and was thermally immature (Aud, 1979).

Commercial hydrocarbons may yet be found either by deeper drilling of the structures already tested, or by finding the prospective Paleogene strata at drillable depths in anticlines as yet untested. However, all of the anticlines in the Yakataga segment are young (late Miocene and younger, with most probably Pliocene and younger), and may have poor potential for generation of hydrocarbons in place, or migration of hydrocarbons into the anticlines since formation of the anticlines.

\section{Middleton Shelf}

Large anticlines are present, but the structure is complex, with steep 
dips and faulting present in most, if not all, of the major anticlines (figs. 19, 20). Much of the area is likely underlain by early Tertiary strata (equivalent to the Orca Formation) which has negligable resource potential, and these strata may be present in the cores of the anticlines as well. Little data is available to analyze trap potential beneath the continental slope. At least one large structure is present at the base of the slope beneath a major bathymetric ridge, Khitrov Ridge (fig. 18; Atwood and others, 1981). This structure is a continuation of the Yakataga segment structural trends.

\section{Pacific Ocean Basin}

Anticlinal traps are present along the base of the slope throughout the Gulf of Alaska and have been discussed with the associated margin segment. No traps are known to be present seaward of the base of the slope.

\section{PETROLEUM POTENTIAL: DISCUSSION}

In the southeast Alaska segment, traps are not known to be present beneath the shelf. At least some young potential anticlinal traps are present on the continental slope. Thick sedimentary strata are present on the slope and at the edge of the shelf. However, the strata are likely of Miocene age and younger, and rocks of this age elsewhere in the Gulf of Alaska have little source or reservoir rock potential. Further, no petroleum seeps or potential source rocks are known to be present in the adjacent onshore areas. We consider this area to have poor petroleum potential.

Dredged and onshore rocks of the Yakutat segment show considerable source rock potential in Eocene and oligocene organic-rich sediments, and especially in an early to middle Eocene sequence in which onshore seeps are found and which showed good organic content in dredge samples. These rocks are immature to marginally mature where dredged on the continental slope, but should be mature beneath the continental shelf. Reservoir properties are less favorable, but some Eocene and Oligocene sandstones have adequate reservoir rock potential. The critical factors for accumulation of hydrocarbons in commercial quantities will be the occurence of adequate traps at drillable depths. At least one large anticline is known. Additional, subtle traps may be present as stratigraphic or structural traps along the Dangerous River structural zone, or over block faulted basement blocks. The Eocene and oligocene sequence has not been tested by drilling on the Yakutat shelf or by drilled wells in the adjacent Yakataga shelf.

Excellent trap potential is present in the Yakataga segment in numerous large anticlines beneath the shelf and slope. In addition, petroleum seeps occur in adjacent onshore structures which continue into the offshore. The Eocene and oligocene rocks in the Yakutat segment continue beneath the thick late Cenozoic strata of the Yakutat segment and may provide potential source and reservoir rocks. These rocks have not been adequately tested by drilling.

Reservoir and source potential of the late Cenozoic strata of the Yakutat and Yakataga segments is poor to negigible, as indicated by unsuccessful drilling in these rocks following ocs lease sale no. 39. The potential for discovering commercial hydrocarbons in the Yakataga segment depends on finding the Eocene and Oligocene strata within drillable depths in the untested 
anticlines, or with deeper drilling on the structures that have already been drilled.

The potential source and reservoir rocks of the Yakataga and Yakutat segments are not known to be present beneath the Middleton segment, either in samples or in the Middleton Island well. Numerous traps are present, but the structure is complex. Potential early and middle Tertiary target horizo,ns may be shallower and therefore more easily drillable than under the Yakataga and Yakutat segments, but may also be breached by erosion in some of the highs. We consider the overall hydrocarbon potential of this segment to be poor.

Too little is known of the Pacific Ocean basin sediments to make a meaningful assessment of petroleum potential. However, these sediments are greater than $2 \mathrm{~km}$ thick only near the base of the slope, are likely young (Miocene and younger), and thermally immature (low geothermal gradient). Traps are present at the base of the slope, but none are known seaward. Reservoir rocks may be developed within turbidite fan complexes. However, our overall assessment is that the petroleum potential of these strata is poor.

Even though drilling results in the Gulf of Alaska have so far been disappointing, there are still reasons for considerable optimism for the discovery of economic hydrocarbons beneath the Yakutat and Yakataga segments. The major positive consideration is the presence of onshore seeps and extractable hydrocarbons from dredge samples that are all from an organicrich sequence of neritic to bathyal marine sediments of early to middle Eocene age. Additional organic-rich samples are also known to be present throughout the Eocene and oligocene sedimentary section from the continental slope of the Yakutat segment.

Most of the samples from the target section are thermally immature. These rocks may be mature beneath the continental shelf at a depth of from 4 to $5 \mathrm{~km}$, based on Lopatin calculations of thermal maturity and on assumptions of burial history and geothermal gradient. Oil is being generated in at least some of these rocks, as indicated by the numerous onshore seeps. The Eoceneoligocene strata are from 2 to $4 \mathrm{~km}$ thick beneath the Yakutat segment and likely extend beneath the Yakataga segment as well. Thus a 2 to $4 \mathrm{~km}$ thick prospective section could underlie an area of about $30,000 \mathrm{~km}^{2}$.

Major negative factors for eventual discovery of commercial hydrocarbons include the negligible potential of the thick late Cenozoic strata, the lack of suitable traps in the Eocene-Oligocene strata of the Yakutat segment, the deep burial of these strata beneath the Yakataga segment, and generally poor reservoir rock potential.

The critical factor for accumulation of commercial petroleum deposits in the Gulf of Alaska probably is the availability of adequate reservoir sandstone in close association with Eocene and Oligocene organic-rich sediments, and especially the early to middle Eocene petroliferous sequence. We believe that the major exploration strategy for the Gulf of Alaska is to search for the Eocene-Oligocene strata in the Yakataga and Yakutat segments. These two margin segments together comprise the Yakutat block, an allochthonous terrain that is moving north with the Pacific plate and colliding with or subducting beneath insular Alaska. Petroleum potential may also be present in the underthrust parts of the Yakutat block, primarily 
onshore, analogous to the Rocky Mountain overthrust belt. The search for economic petroleum discoveries is largely dependant on finding the Eocene and Oligocene strata in favorable trap locations at drillable depths. Major unknowns are whether migration of hydrocarbons has occured into such traps, and whether sufficient reservoir rock is present to allow commercial accumulations of hydrocarbons. 
CHAPTER II

GEOLOGY, STRUCTURE, AND PETROLEUM POTENTIAL

OF THE LOWER COOK INLET-SHELIKOF STRAIT REGION

by

Michael A. Fisher and Leslie B. Magoon

INTRODUCTION

Federal ocs (Outer Continental Shelf) Sale No. 88 is proposed for lower Cook Inlet and Shelikof Strait in southern Alaska (fig. 1). Although the proximity and similar geology of the upper and lower parts of Cook Inlet suggest that, like upper cook Inlet, lower cook Inlet should contain hydrocarbon resources, eight exploration wells drilled after the lease sale in 1977 failed to discover economic concentrations of hydrocarbons. Tracts in lower cook Inlet were reoffered and tracts in northern shelikof strait were offered for the first time in lease sale 60 (1981).

This report is abstracted and updated from Magoon and others (1979), and it summarizes the geologic setting and petroleum geology of the lower cook Inlet and the Shelilof strait. Work in Cook Inlet basin (upper and lower Cook Inlet) by the petroleum industry and the U.S. Geological survey led to the following main reports on the geology of this area: Detterman and Hartsock (1966), Kirschner and Lyon (1973), Boss, Lennon and Wilson (1976), Magoon, Adkison and Egbert (1976), and Fisher and Magoon, (1978), and Detterman and Reed, (1980). Reports concerning the framework geology of the Shelikof strait area include Keller and Reiser (1959), Burk (1965), Moore (1967), Moore (1974), Imlay and Detterman (1977), Connelly and Moore (1979), and Detterman and others $(1981 \mathrm{a}, \mathrm{b})$. Publications on the petroleum geology of lower Cook Inlet include Kelley (1963, 1968), Alaska Geological Society (1970), Magoon and others (1975, 1976), Miller (1975), Blasko (1976a, 1976b), Claypool and others (1980), and Magoon and Claypool (1981). No publications on the petroleum geology for the Shelikof strait exist.

\section{GENERAL GEOLOGY}

Rocks of lower Cook Inlet are part of a belt of Mesozoic and Cenozoic sedimentary rocks that underlie upper Cook Inlet on the northeast and the Alaska Peninsula and the shelikof strait on the southwest. Locally along this belt, marine Mesozoic rocks may be more than 11,000 m thick, and continental Cenozoic rocks are as much as 7,600 m thick. Four major northeast-trending geologic features that flank Cook Inlet are the Alaska-Aleutian Range batholith and the Bruin Bay fault on the northwest side, and the Border Ranges fault and the terrane of undifferentiated Mesozoic and Cenozoic rocks on the southeast side. The geology of the cook Inlet-shelikof strait area is shown on figures 2,3 , and 4 .

The Alaska-Aleutian Range batholith is mostly quartz diorite. Although younger plutons exist, most of the batholith was emplaced between 176 and 154 m.y. ago, or during Middle and Upper Jurassic time. The high-angle reverse Bruin Bay fault, can be traced along the northwest side of the lower Cook Inlet basin for $215 \mathrm{~km}$. The fault plane dips about 600 northwest and throw 
measured across the fault is as much as $3,000 \mathrm{~m}$.

A fault near Seldovia, part of the Border Ranges fault system, is interpreted to extend northeast ward from Seldovia beneath the Kenai lowland, and southwestward from there at least as far as the southwest end of Kodiak Island. In the Kenai lowland, the fault is overlapped by Tertiary sedimentary rocks, but in the Seldovia area, the fault separates possibly petroliferous Jurassic through Cretaceous shelf deposits on the west from Mesozoic; crystalline rocks, melange, and turbidite deposits (Mesozoic undifferentiated on fig. 3) on the east that can neither be source nor reservoir for hydrocarbons.

Sedimentary rocks of Triassic and Early Jurassic age lie beneath the sale area bet ween the Alaska-Aleutian Range batholith and the Mesozoic melange and flysch deposits. On the northwest side of lower cook Inlet, rocks of Late Triassic age are as much as $395 \mathrm{~m}$ thick and consist of metamorphosed limestone, tuff, chert, sandstone, shale, and basaltic lava flows. On the southwest side of lower Cook Inlet, Upper Triassic rocks exposed west of the Border Ranges fault consist of fossiliferous marine limestone and fine-grained tuff. Upper Triassic rocks are also exposed on the Barren, Shuyak, and Kodiak Islands and near Puale Bay (located along the southwest Coast of the Alaska Peninsula). Rocks of Early Jurassic age are exposed on both sides of the Inlet. On the northwest side, Lower Jurassic rocks are as much as $2527 \mathrm{~m}$ thick and dip generally southeast. They consist of poorly bedded volcanic agglomerates, breccias, and lava flows. On the southeast side of the Inlet, Lower Jurassic strata are about $300 \mathrm{~m}$ thick and consist of volcanic tuff, agglomerate, and breccia, and interbedded marine sandstone, shale, and limestone. Near Shelikof Strait, Jurassic rocks crop out near Puale Bay. The presence of the Upper Triassic and Lower Jurassic rocks around lower Cook Inlet and Shelikof Strait and in some offshore areas suggest that these rocks are continuous beneath the inlet and the strait. The Upper Triassic and Early Jurassic rocks do not have petroleum potential and are considered economic basement.

Unconformably overlying the Lower Jurassic volcaniclastic rocks are Middle and Upper Jurassic marine sedimentary rocks that are as thick as 7000 $\mathrm{m}$. These rocks are exposed on the west side of lower cook Inlet, crop out on the northern Alaska Peninsula, and have been penetrated by onshore and offshore wells. Thus, these rocks underlie the entire sale area extensively. The Middle Jurassic rocks are believed to be the source for the oil being produced in upper cook Inlet. Upper Jurassic sandstones have very poor to inadequate reservoir properties. Unconformable contacts between the Middle and Upper Jurassic strata probably produce the deepest reflections evident in our seismic data.

In the area of lower Cook Inlet, $215 \mathrm{~m}$ of Lower Cretaceous siltstone and sandstone unconformably overlies Upper Jurassic strata in the Kamishak Hills, and the unit is present beneath lower cook Inlet and probably Shelikof Strait. The Lower Cretaceous shale is not a potential source rock for hydrocarbons, but the sandstone has fair reservoir properties. This unit is bounded by unconformities that may be good seismic reflectors.

Upper Cretaceous rocks crop out in the Kamishak Hills-Cape Douglas area, where $1,385 \mathrm{~m}$ of these rocks unconformably overlie Lower Cretaceous strata. 


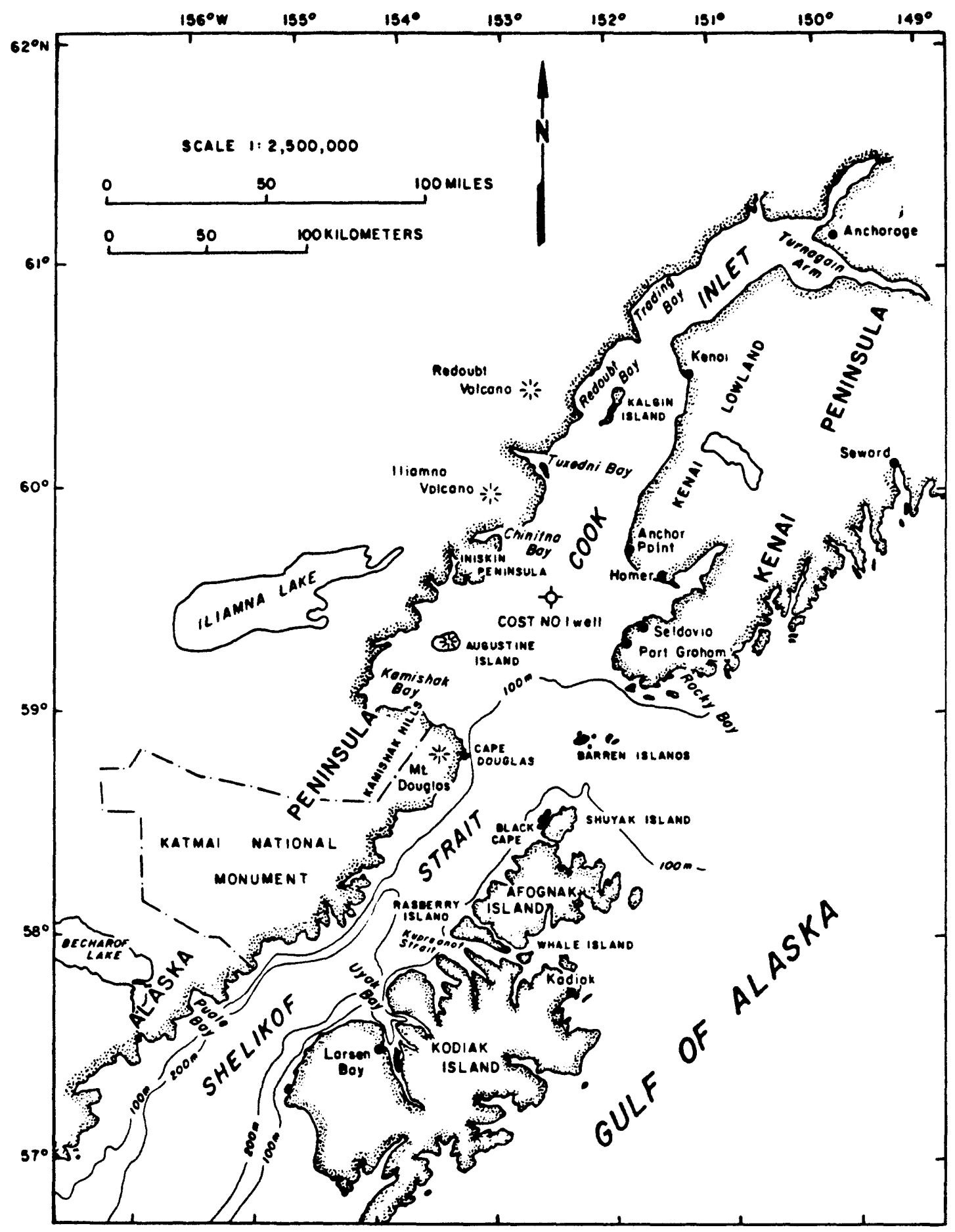

Figure 1. Geography of the area of cook Inlet and Shelikof strait. The cosm No. I well is located in lower cook Inlet. 


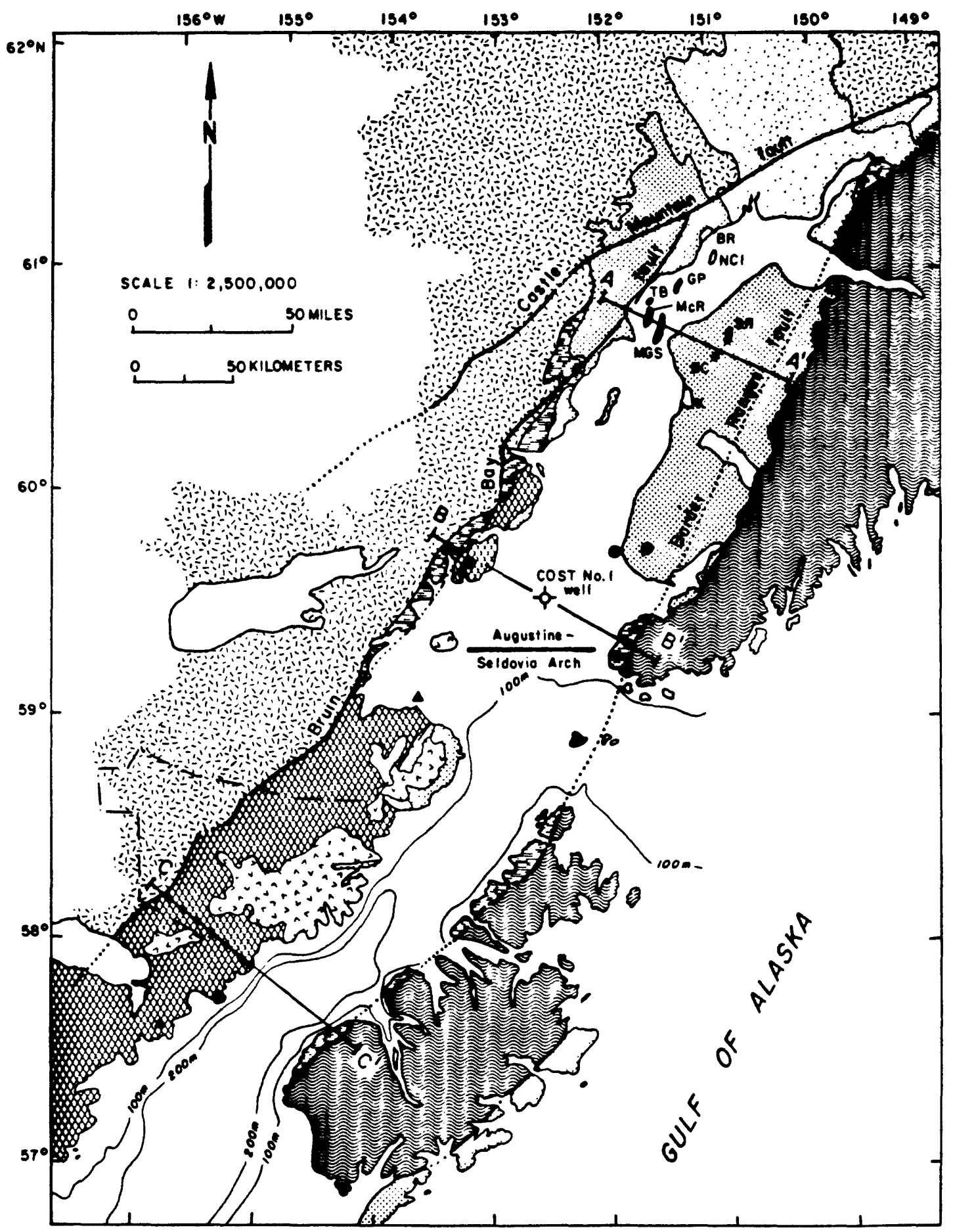

Figure 2. Onshore geology of areas adjacent to cook Inlet and Shelikof strait. Symbols explained in figure 3 . Locations of the cross sections $A-A^{\prime}, B-B^{\prime}$, and $C-C^{\prime}$, presented in figure 5 , are shown. Indications of oil in wells and at the surface are shown around lower Cook Inlet and on the Alaska Peninsula. 


\section{EXPLANATION}

Figures 3,5 and 6

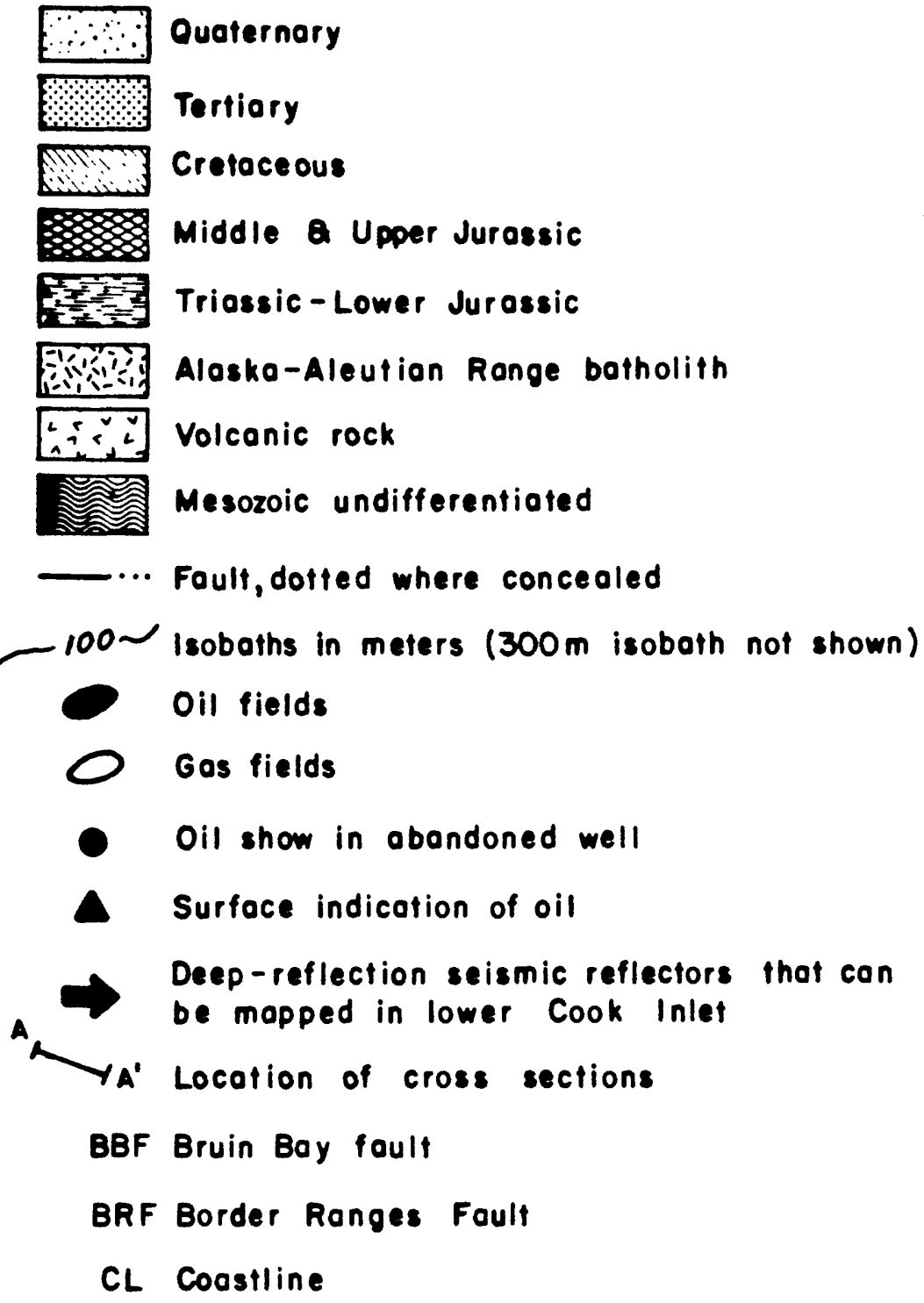

GAS FIELDS

K Kenai

BR Belugo River $\mathrm{NCl}$ North Cook inlet
OIL FIELDS

GP Granite Point

TB Trading Boy

SR Swanson River MCR MacArthur River

MGS Middle Ground Shool BC Beover Creek

Figure 3. Explanation of symbols and abreviations used on figures 2,4 . and 5 . 


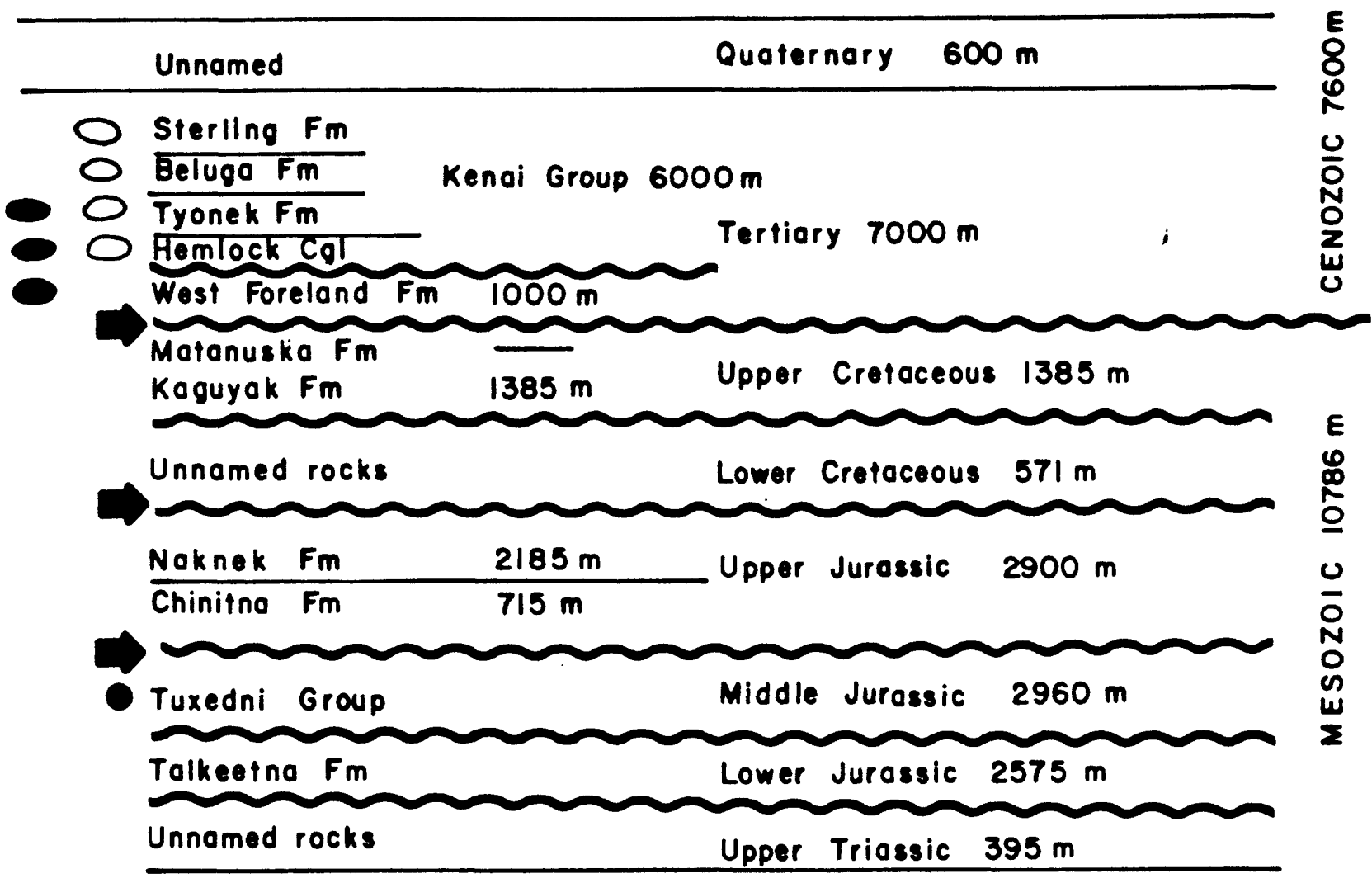

Figure 4. Stratigraphic names and thicknesses of the rock units located between the Alaska-Aleutian Range batholith and the undifferentiated Mesozoic rocks (Fig. 2). Indications of oil and gas in the rock units are shown. Three seismic reflectors, mapped in lower cook Inlet (Fisher and Magoon, 1978), are indicated by arrows and are used to make cross section $B^{-} B^{\prime}$. Refer to figure 3 for explanation of symbols. 
Upper Cretaceous strata are present from the upper cook Inlet to the Kamishak Hills, and were encountered in the lower cook Inlet COST No. 1 well. This distribution of Upper Cretaceous rocks suggest that these rocks are present extensively below the sale area. In upward succession, this formation consists of shallow-marine sandstone, bioturbated gray siltstone, and turbidite sandstone and siltstone. Upper Cretaceous shale and siltstone are not potential source rocks for hydrocarbons, but the sandstone has good reservoir properties.

Tertiary rocks near lower Cook Inlet are all nonmarine and consist of the West Foreland Formation and the overlying Kenai Group. The conglomeratic West Foreland Formation includes much tuffaceous and volcaniclastic material. This unit unconformably overlies Mesozoic rocks. Near Cape Douglas the unit attains a maximum thickness onshore of $1,000 \mathrm{~m}$. The West Foreland Formation is penetrated by wells on the Kenai lowland and offshore by the lower Cook Inlet COST No. 1 well (419 m thick). The West Foreland Formation is not a source for oil, but it may be a source for gas. The conglomeratic sandstone has good to excellent reservoir properties. The Kenai Group unconformably overlies the West Foreland Formation and consists of conglomerate, sandstone, siltstone, and coal. Well data indicate that the total Tertiary sequence is about $7,000 \mathrm{~m}$ thick north of Kenai, whereas outcrop data obtained near Cape Douglas show that Tertiary rocks are only about $1,850 \mathrm{~m}$ thick. The Kenai Group rocks are not a source for oil but they can produce gas at low temperatures. Sandstone and conglomerate in this group are excellent reservoirs for oil and gas. The widespread unconformity between Mesozoic and Tertiary rocks is a good reflector of seismic energy.

The Atlantic Richfield Company lower Cook Inlet COST No. 1 well penetrated the West Foreland Formation, Upper and Lower Cretaceous rocks, and Upper Jurassic rocks. Sandstones of potential reservoir quality were encountered in the West Foreland Formation, and in Upper and possibly in Lower Cretaceous rocks. The Upper Jurassic rocks contain zeolites that destroyed the reservoir quality of these rocks; the reservoir-quality of cores from this well is very poor to inadequate. All rocks penetrated by this well contain insufficient organic material or were not heated enough to generate commercial amounts of oil or gas.

Modal analyses of 38 thin sections from Upper Jurassic rocks in the cosT well indicate an average composition of $\ell_{24} F_{55} I_{21}$ (lithofeldspathic sandstone). Only 12 of 172 recorded sidewlil cores have favorable reservoir properties. The average porosity and permeability of sandstones from sidewall cores is 17.9 percent and 39 millidarcies, respectively. Lower Creataceous rocks include a calcite-rich sandstone that contains no zeolite; nevertheless, these rocks are diagenetically altered. Modal analyses of 37 thin sections indicate an average composition of $\Omega_{36} \mathrm{~F}_{44} \mathrm{~L}_{20}$ (lithofeldspathic sandstone). The average porosity and permeability of sandstones from sidewall cores is 21.5 percent and 80 millidarcies, respectively. Conventional cores contain sandstones that average 13.9 percent porosity and 0.3 millidarcies permeability. Modal analyses of 21 thin sections from Upper Cretaceous rocks have an average composition of $\Omega_{23} F_{61} L_{16}$ (feldspathic sandstone). The average porosity and permeability of sandstones from sidewall cores is 22.8 percent and $43 \mathrm{millidarcies,} \mathrm{respectively.} \mathrm{Modal} \mathrm{analyses} \mathrm{of} \mathrm{eight} \mathrm{thin} \mathrm{sections} \mathrm{from}$ 
lower Tertiary rocks have composition of $\ell_{23} F_{30} L_{47}$ (feldspatholith sandstone). The average porosity and permeability from sidewall cores is 22.7 percent and 108 millidarcies, respectively.

\section{OFFSHORE STRUCTURE}

Mesozoic rocks that fill the basin beneath lower cook Inlet and Shelikof Strait are deformed into a broad geosyncline. The axis of this feature strikes northeast and it follows the northeast coast of the Alaska Peninsula. This axis then continues to the northeast below the middle of lower Cook Inlet. Particularly along the Alaska Peninsula, rocks that form the northwest limb of the geosyncline are deeply eroded, so that mainly Jurassic rocks are exposed. The southeast limb is truncated by the unconformity at the base of Cenozoic rocks (fig. 5). Beneath the southern two-thirds of the sale area, Mesozoic rocks of this truncated limb are buried by only 1 to $2 \mathrm{~km}$ of Cenozoic rocks (fig. 6 ).

Superimposed on the geosyncline are local structures, one of which is transverse to the basin axis. These local structures include a lineation of small anticlines that lies near the southeast flank of lower cook Inlet, a few small, isolated anticlines that lie beneath Shelikof strait, and the Augustine-Seldovia arch that trends transversely across the basin (fig. 6 ). These structures could be traps for hydrocarbons, and most of them have already been leased.

Gravity contours generally mimic contours of the thickness of Cenozoic rocks. Over the northern part of the sale area, north of the AugustineSeldovia arch, gravity values decrease steadily in the same direction in which Cenozoic rocks thicken (fig. 7). Gravity contours outline the AugustineSeldovia arch, and over lower cook Inlet and Shelikof Strait, gravity values are mainly in the range of +10 to $-10 \mathrm{mgal}$. In this same area, Cenozoic rocks are less than $2 \mathrm{~km}$ thick. One gravity low of -40 mgal occurs in southern Shelikof strait where Cenozoic rocks thicken locally to between 2 and $2.5 \mathrm{~km}$.

\section{PETROLEUM GEOLOGY}

Commercial oil production in the region of this lease sale is restricted to Tertiary rocks in upper cook Inlet -- 80 percent of the oil is from the Hemlock Conglomerate; 18 percent is from the Kenai Group; and the remaining 2 percent is from the West Foreland Formation (fig. 4). Other indications of the presence of hydrocarbons in the sale area include oil that was recovered in a test of the Hemlock Conglomerate in two wells near Homer, and oil shows from the Middle Jurassic rocks were detected in wells drilled on the Iniskin Peninsula. Moreover, a "dead" oil smell emanates from Upper Jurassic rocks near Cape Douglas, and a series of seeps is located between Becharof Lake and Puale Bay, on the Alaska Peninsula (fig. 2).

The richness, type, and thermal maturity of organic matter in cook Inlet sedimentary rocks was evaluated by thermal-evolution analysis employing a flame ionization detector (TEA-FID). In this analysis, a small sample of rock is heated under controlled conditions and hydrocarbons are measured as they are evolved from the rock.

The most likely sources of cook Inlet hydrocarbons are nonmarine 

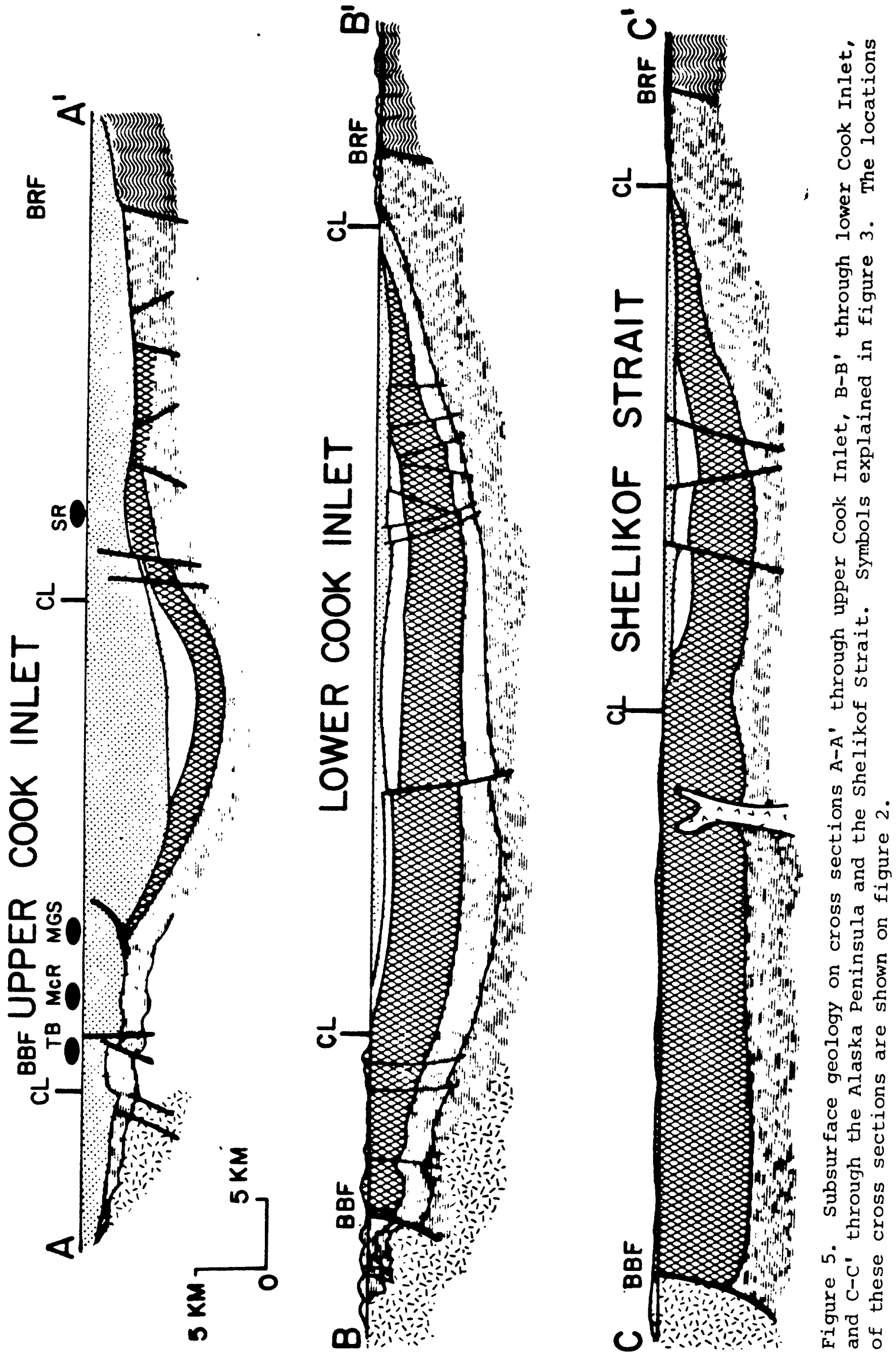


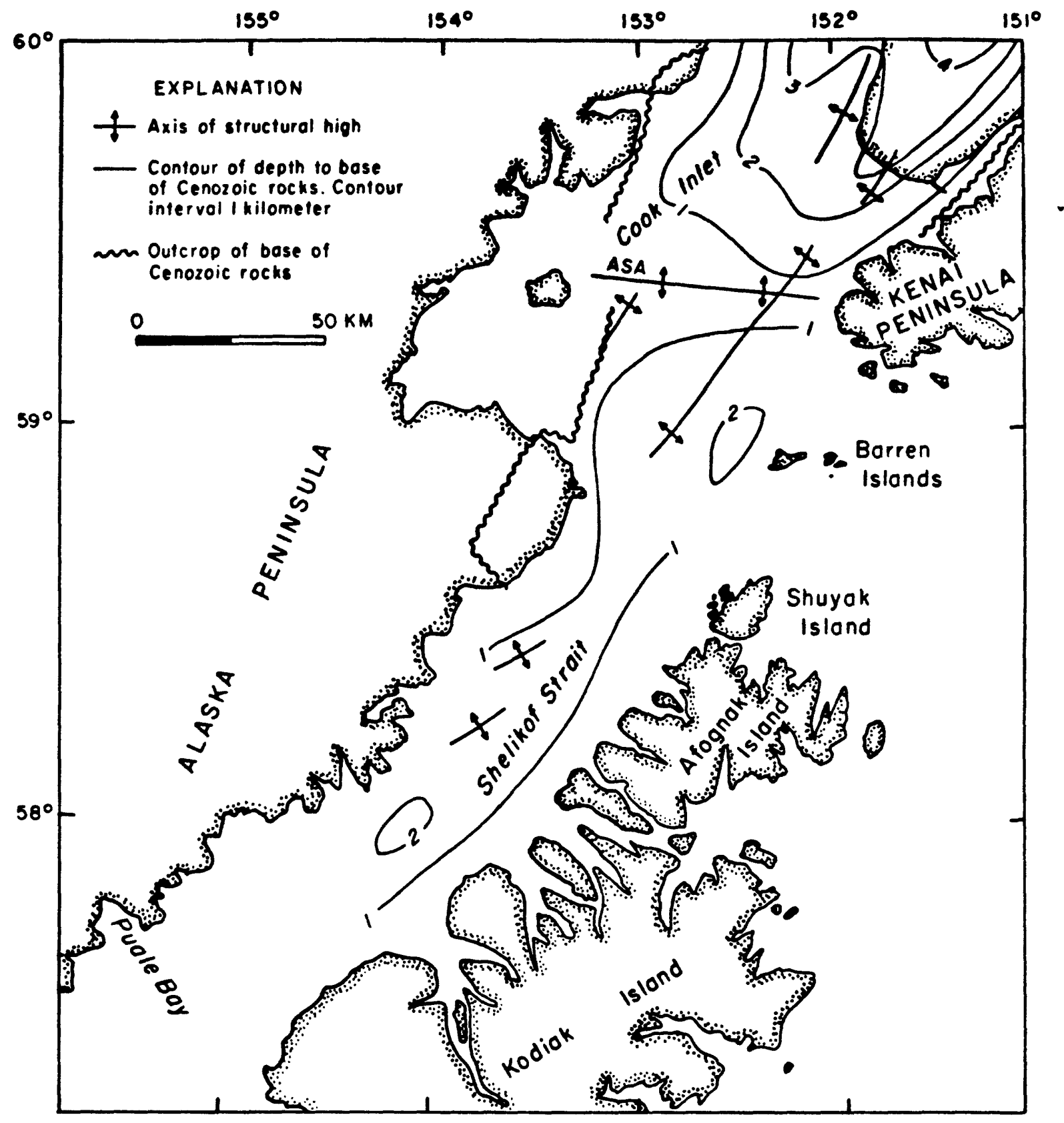

Figure 6. Structural contours on base of Cenozoic rocks. ASA: AugustineSeldovia arch. 


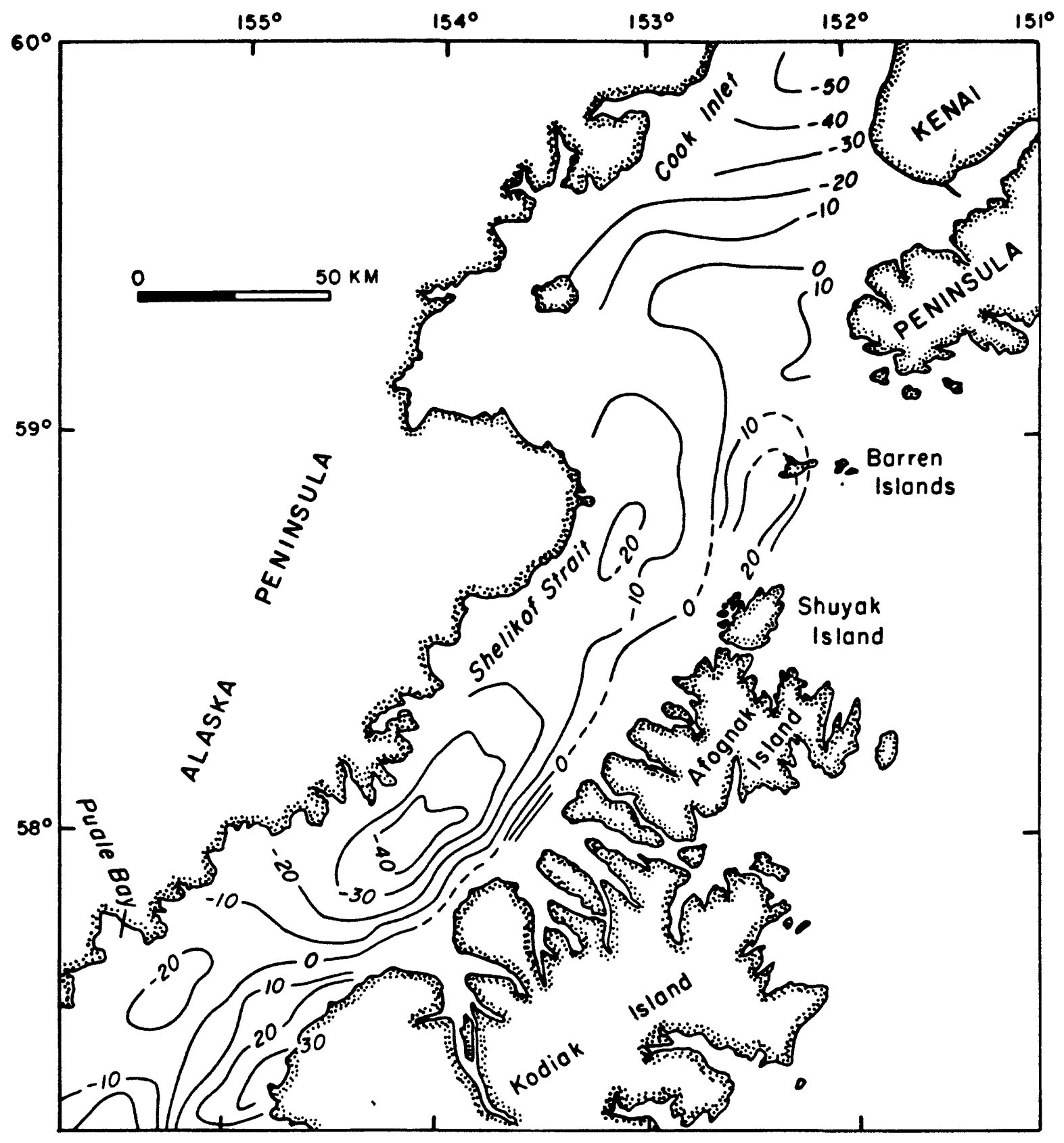

Figure 7. Contours of free-air gravity. Contour interval 10 mgal. 
Tertiary, marine Cretaceous, and marine Middle Jurassic sequences. The nonmarine Tertiary sequence is rich in organic matter mainly because of the presence of coal. The samples analyzed are potential source rocks, in terms of organic richness, and they have reached thermal maturity.

The type of organic matter and thermal maturity have been determined for rocks from five wells from the Iniskin Peninsula to the Kenai lowland. ;Middle Jurassic rocks, according to TEA-FID a nalyses, are the only potential oil source rocks. Rocks of this age under the Kenai lowland are thermally immature, whereas, rocks on the Iniskin Peninsula are mature.

Saturated hydrocarbons extracted from Cretaceous and Tertiary rocks by solvents and analyzed by gas chromotography do not resemble cook Inlet petroleum. Solvent extracts from Middle Jurassic rocks on the Iniskin Peninsula, however, are similar to Cook Inlet petroleum.

The kind and amount of organic matter and the degree of thermal maturity of the rocks penetrated in the COST No. 1 well are unfavorable for generation of significant amounts of hydrocarbons. The organic carbon content from sidewall cores generally is less than 0.4 wt percent. Gas content (methane through butane) of drill cuttings is low and decreases in concentration with increasing depth of burial. The reflectance of vitrinite increases with depth, and reaches a maximum of 0.65 percent at total depth. This value signifies the very beginning of the oil-generation zone. Thermal alteration index (TAI) values approach three and indicate a thermal alteration sufficient for hydrocarbons to have been generated but no organic-rich rocks are present to generate oil or gas.

\section{Oil Fields}

Producing oil fields in upper cook Inlet are located on the east and west flank of the basin. East flank fields include Swanson River and Beaver Creek; west flanks fields include Middle Ground Shoal, McArthur River, Trading Bay and Granite Point. All these fields are structural traps--anticlines or faulted anticlines with separate oil pools, or productive horizons having separate oil-water contacts. Oil reservoirs are nonmarine sandstone and conglomerate. Initial gas-oil ratios (GOR) range from 65 to 1,110 .

For oil to migrate from the Middle Jurassic source rocks into the lower Tertiary reservoir rocks requires that migration occurred prior to deformation of the Beluga and Tyonek Formations and Hemlock Conglomerate. Rocks of this age thin to the west causing, thereby, an eastward dip of the Hemlock Conglomerate and Tyonek Formation reservoir rocks. High porosity and permeability in the West Foreland Formation in the McArthur River field area provided an avenue for oil migration from the Middle Jurassic source rocks through the West Foreland Formation and into the overlying Hemlock Conglomerate and Tyonek Formation. A conceptual exploration model includes first a series of oil fields in stratigraphic traps on the west flank of the Cook Inlet basin at the end of the time of deposition of the Beluga Formation, and later deformation may have remobilized the stratigraphically trapped oil, allowing it to migrate into the present-day structural traps. 
Producing gas fields in upper Cook Inlet are the Beluga, North Cook Inlet, and Kenai gas fields. The gas in these fields is not associated with oil. Nonassociated gas occurrences are confined to the shallower Sterling, Beluga, and Tyonek Formations of the Kenai Group. In other fields, gas is associated with oil, and gas occurrences are limited to the deeper and older Tyonek Formation and Hemlock Conglomerate of the Kenai Group, and the West Foreland Formation. Nonassociated gas is only methane, with a carbon isotope ratio between -56 to -62 per mil PDB. Associated gas contains methane through butane, and the carbon-isotope ratio ranges from -43 to -49 permil. The isotope ratios for nonassociated gas indicate a low-temperature biologic origin, whereas carbon isotope values for associated gas indicate a thermal origin. The nonassociated gas originates from nonmarine sedimentary rocks of the Sterling, Beluga, and Tyonek Formations, and the associated gas comes from the Middle Jurassic.

\section{Hydrocarbon Potential of the Sale Area}

The first lease sale (CI) held for this area attracted bids totaling about $\$ 400,000,000$. The second sale, even though it included a larger area than the first, attracted a total of only about $\$ 4,000,000$. On the basis of this one-hundred-fold decrease in total bids, this third proposed sale cannot be expected to stimulate much interest from oil companies. This disinterest derives from disappointing results of drilling eight exploratory wells in lower cook Inlet and from the expectation that reservoir rocks are of poor quality or are at shallow depth below Shelikof Strait. Information from our seismic-reflection data suggest that tracts over the obvious structural traps have been leased, and some of these traps have already been drilled. Hence, this third lease sale offers mainly subtle traps that require more detailed data to assess than the amount of data we have.

From our data and from the pattern of bidding and drilling by oil companies, the areas of greatest interest are over an anticlinal lineation along the southeast side of lower Cook Inlet, over the Augustine-Seldovia arch, and over anticlines that follow the axis of shelikof strait. These areas may be targets for more bidding. In addition, gas in upper Tertiary rocks adjacent to the Kenai lowland could be a target of exploration.

Below Shelikof Strait, Middle Jurassic rocks are probably present, and they could be source rocks for hydrocarbons. These rocks are at considerable depth under the Alaska Peninsula, but they are at progressively shallower depth southeastward from the peninsula, under the strait. Offshore, these Jurassic rocks are truncated by the unconformity at the base of cenozoic rocks, possibly leading to the same geometry as in some upper cook Inlet oil fields where Cenozoic reservoirs overlie directly Middle Jurassic source rocks.

In the Katmai National Monument, Tertiary volcanic rocks intrude Middle Jurassic rocks, providing a local source of heat to generate oil and gas. Mesozoic rocks at Cape Douglas were similarly heated by igneous intrusion, and they are thermally mature for oil and gas. The surficial indications of oil near Becharof Lake and Puale Bay may have been generated by this heat 
source. Depth of burial of Middle(?) Jurassic rocks under the Alaska Peninsula may be sufficient to generate oil and gas. 


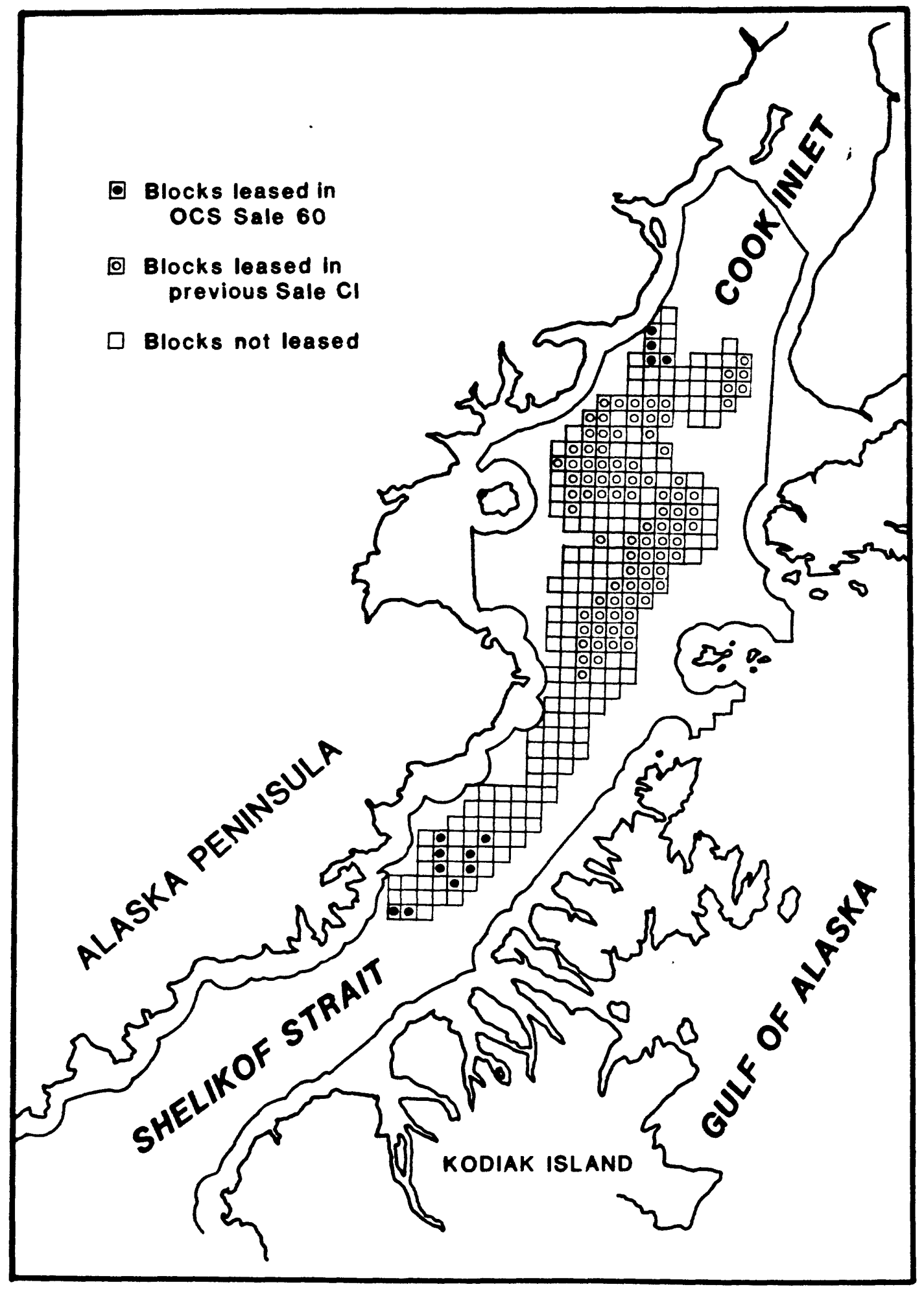

Figure 8. Offshore tracts leased previously in sales CI and 60 . 
CHAPTER III

\section{RESOURCE ASSESSMENT}

$$
\text { by }
$$

Robert H. McMullin

The planning area for proposed ocs sale 88 includes Federal lands in five different geological provinces used in the Geological Survey estimates of oil and gas resources of the United States (Dolton and others, 1981). Estimates of the economically recoverable oil and gas resources for the Cook Inlet Province, the Shelikof strait Province shallow $(0-200 \mathrm{~m})$, the Eastern Gulf of Alaska Shelf $(0-200 \mathrm{~m})$, and the Eastern Gulf of Alaska Slope $(200-2400 \mathrm{~m})$ are shown in tables 1 through 4. The estimated resources for the Shelikof Strait deep (deeper than $200 \mathrm{~m}$ ) are negligible. Estimates for the Cook Inlet and Shelikof Strait shallow (0-200 m) must be reduced as part of the resources are on State lands in these provinces. The Federal portion of the resources in Cook Inlet is estimated to be 25 percent and in the Shelikof straits shallow it is estimated to be 95 percent of the total resources for each province.

Estimates shown in tables 1 through 4 are assessments of undiscovered recoverable oil and gas. These quantities are considered recoverable at current cost and price relationships and with current technology, assuming additional short-term technological growth. The assessments are probability estimates of "more than" quantities associated with given probabilities of occurrence. The estimates are stated two ways. First, the conditional estimates are those quantities associated with given probabilities of occurrence. Second, the unconditional estimates are those quantities that may be present when the probability of finding commercial hydrocarbons in frontier areas is uncertain and a marginal probability is estimated to express this risk. The marginal probability and conditional estimates are used to calculate the unconditional values.

The aggregated gas estimates include associated/dissolved gas and nonassociated gas. Three possibilities exist for the occurrence of gas resources. A basin might contain both associated/dissolved gas and nonassociated gas, only non-associated gas, or only associated/dissolved gas. All three cases are included in the estimates for the total aggregated gas in this assessment.

Subjective probability techniques were used to make the province assessments and these techniques incorporate geologic judgment and analyses of petroleum characteristics of the basin. The analytical procedures include:

1. A review and interpretation of available geological and geophysical data.

2. Application of arbitrary hydrocarbon yields derived from various United States hydrocarbon-producing basins.

3. Comparison with other petroleum provinces. 
Table 1

Estimates of Total Undiscovered 011 and Gas, Cook Inlet 1

\begin{tabular}{|c|c|c|c|c|}
\hline & $\begin{array}{c}95 \text { th } \\
\text { Fractile }\end{array}$ & $\begin{array}{c}5 \text { th } \\
\text { Fractile } \\
\end{array}$ & Mean & $\begin{array}{c}\text { Marginal } \\
\text { Probability }\end{array}$ \\
\hline $\begin{array}{l}011 \text { (B1llions of barrels) } \\
\text { Conditional } \\
\text { Unconditional }\end{array}$ & $\begin{array}{l}.09 \\
.09\end{array}$ & $\begin{array}{l}.99 \\
.99\end{array}$ & $\begin{array}{l}.36 \\
.36\end{array}$ & 1.0 \\
\hline $\begin{array}{l}\text { Assoc./Dissolved Gas }(\mathrm{TCF})^{3} \\
\text { Conditional } \\
\text { Unconditional }\end{array}$ & $\begin{array}{l}.05 \\
.05\end{array}$ & $\begin{array}{l}.59 \\
.59\end{array}$ & $\begin{array}{l}.21 \\
.21\end{array}$ & 1.0 \\
\hline $\begin{array}{l}\text { Non-Assoc. Gas }(\mathrm{TCF})^{3} \\
\text { Conditional } \\
\text { Unconditional }\end{array}$ & $\begin{array}{l}.67 \\
.67\end{array}$ & $\begin{array}{l}4.58 \\
4.58\end{array}$ & $\begin{array}{l}1.98 \\
1.98\end{array}$ & $\begin{array}{l}1.0 \\
--\end{array}$ \\
\hline $\begin{array}{l}\text { Aggregated Gas }(\mathrm{TCF})^{3} \\
\text { Conditional } \\
\text { Unconditional }\end{array}$ & $\begin{array}{l}.85 \\
.85\end{array}$ & $\begin{array}{l}5.03 \\
5.03\end{array}$ & $\begin{array}{l}2.19 \\
2.19\end{array}$ & 1.0 \\
\hline
\end{tabular}

1 Federal lands beyond the three-mile limit are estimated to contain 25 percent of these resources.

2 The probability of more than the amount at the 95 th fractile is 95 percent. The 5th fractile is defined similarly.

3 TCF, trillion cubic feet. 
Estimates of Total Undiscovered 011 and Gas, Shelikof Straits shallow $(0-200 \mathrm{~m})$

\begin{tabular}{|c|c|c|c|c|}
\hline & $\begin{array}{c}95 t h \\
\text { Fractile }\end{array}$ & $\begin{array}{c}5 t h \\
\text { Fract1le } \\
\end{array}$ & Mean & $\begin{array}{c}\text { Marginal } \\
\text { Probability }\end{array}$ \\
\hline $\begin{array}{l}011 \text { (Billions of barrels) } \\
\text { Conditional } \\
\text { Unconditional }\end{array}$ & $0^{.05}$ & $\begin{array}{l}.82 \\
.21\end{array}$ & $\begin{array}{l}.25 \\
.04\end{array}$ & .16 \\
\hline $\begin{array}{l}\text { Assoc./Dissolved Gas }(\mathrm{TCF})^{3} \\
\text { Conditional } \\
\text { Unconditional }\end{array}$ & $0^{.03}$ & $\begin{array}{l}.49 \\
.13\end{array}$ & $\begin{array}{l}.15 \\
.02\end{array}$ & .16 \\
\hline $\begin{array}{l}\text { Non-Assoc. Gas }(T C F)^{3} \\
\text { Conditional } \\
\text { Unconditional }\end{array}$ & $0^{.28}$ & $\begin{array}{r}1.94 \\
.72\end{array}$ & $\begin{array}{l}.74 \\
.13\end{array}$ & .17 \\
\hline $\begin{array}{l}\text { Aggregated Gas }(\mathrm{TCF})^{3} \\
\text { Conditional } \\
\text { Unconditional }\end{array}$ & $0^{.04}$ & $\begin{array}{r}1.56 \\
.79\end{array}$ & $\begin{array}{l}.50 \\
.15\end{array}$ & .30 \\
\hline
\end{tabular}

1 Federal lands beyond the three-mile limit are estimated to contain 95 percent of these resources.

2 The probability of more than the amount at the 95 th fractile is 95 percent. The 5th fractile is defined similarly.

3 TCF, trillion cubic feet. 
Table 3

Estimates of Total Undiscovered 011 and Gas, Eastern Gulf of Alaska Shelf $(0-200 \mathrm{~m})^{1}$

\begin{tabular}{|c|c|c|c|}
\hline $\begin{array}{c}95 \text { th } \\
\text { Fract11 } \mathrm{e}^{2}\end{array}$ & $\begin{array}{l}5 \text { th } \\
\text { Fract } 11 e^{2}\end{array}$ & Mean & $\begin{array}{l}\text { Marginal } \\
\text { Probability }\end{array}$ \\
\hline
\end{tabular}

011 (Billions of barrels)

Conditional

Unconditional

$\begin{array}{rrrr}.21 & 2.89 & 1.04 & .25\end{array}$

Assoc./Dissolved Gas $(\mathrm{TCF})^{3}$

Conditional

Unconditional

$.32 \quad 4.34$

2.22

1.57

.25

Non-Assoc. Gas (TCF) ${ }^{3}$

Conditional

Unconditional

$0^{.82}$

9.14

5.89

3.44

1.27

.37

Aggregated Gas (TCF) ${ }^{3}$

Conditional

Unconditional

$0^{.46}$

9.24

6.93

3.14

1.67

.53

1 Federal lands beyond the three-mile limit are estimated to contain all of these resources.

2 The probability of more than the amount at the 95 th fractile is 95 percent. The 5 th fractile is defined similarly.

3 TCF, trillion cubic feet. 
Table 4

Estimates of Total Undiscovered 011 and Gas, Eastern Gulf of Alaska Slope $(200-2400 \mathrm{~m})^{1}$

\begin{tabular}{|c|c|c|c|c|}
\hline & $\begin{array}{c}95 \text { th } \\
\text { Fractile } 2 \\
\end{array}$ & $\begin{array}{c}5 \text { th } \\
\text { Fract } 11 e^{2} \\
\end{array}$ & Mean & $\begin{array}{c}\text { Marginal } \\
\text { Probability }\end{array}$ \\
\hline $\begin{array}{l}011 \text { (Billions of barrels) } \\
\text { Conditional } \\
\text { Unconditional }\end{array}$ & $0^{.20}$ & $\begin{array}{r}2.03 \\
.67\end{array}$ & $\begin{array}{l}.74 \\
.10\end{array}$ & $\begin{array}{l}.14 \\
--\end{array}$ \\
\hline $\begin{array}{l}\text { Assoc./Dissolved Gas }(\mathrm{TCF})^{3} \\
\text { Conditional } \\
\text { Unconditional }\end{array}$ & $0^{.30}$ & $\begin{array}{l}3.04 \\
1.00\end{array}$ & $\begin{array}{r}1.10 \\
.15\end{array}$ & .14 \\
\hline $\begin{array}{l}\text { Non-Assoc. Gas }(\mathrm{TCF})^{3} \\
\text { Conditional } \\
\text { Unconditional }\end{array}$ & $0^{.85}$ & $\begin{array}{l}3.92 \\
1.69\end{array}$ & $\begin{array}{r}1.72 \\
.28\end{array}$ & .16 \\
\hline $\begin{array}{l}\text { Aggregated Gas (TCF) } \\
\text { Conditional } \\
\text { Unconditional }\end{array}$ & $0^{.36}$ & $\begin{array}{l}3.70 \\
2.15\end{array}$ & $\begin{array}{r}1.53 \\
.43\end{array}$ & .28 \\
\hline
\end{tabular}

1 Federal lands beyond the three-mile limit are estimated to contain all of these resources.

2 The probability of more than the amount at the 95 th fractile is 95 percent. The 5th f $\overline{r a c t i} \overline{l e}$ is defined simllarly.

3 TCF, trillion cubic feet. 


\section{CHAPTER IV}

NORTHERN GULF OF ALASKA ENVIRONMENTAL GEOLOGY

by

Paul R. Carlson and William C. Schwab

\section{INTRODUCTION}

A high level of tectonism combined with numerous large winter storms makes the Gulf of Alaska continental margin a hostile environment in which to explore for hydrocarbons. These two phenomena plus the deposition of copious quantities of fine sediment carried to the Gulf of Alaska by glacial meltwater streams and rivers create potential seafloor geologic hazards. These hazards include active faults, high seismicity, unstable sediment deposits, zones of shallow overpressured or gas-charged sediment that may be encountered during drilling, and areas of excessive erosion or deposition.

In conjunction with OCS lease sales 39 and 55 in the northern Gulf of Alaska, studies have been conducted in which the seafloor hazards have been delineated and discussed. This chapter will draw from and augment these reports, and will also present information for the continental margin off southeastern Alaska. The discussion of seafloor hazards will proceed from east to west using the same physiographic and geologic subdivisions as Bruns and Plafker (this report).

\section{SOUTHEASTERN ALASKA SEGM ENT}

The continental shelf between Dixon Entrance and Cross Sound is much narrower (20-40 km wide) and less-well studied than areas to the west. During the summer of 1978, two U.S. Geological Survey cruises ran seismic lines totaling $1500 \mathrm{~km}$ across the shelf southeast of Palma Bay (fig. 1). A major objective of the $R / V$ SEA SOUNDER cruise (s-5-78) was to trace the offshore extension of the Fairweather fault. To accomplish this objective, three seismic reflection profiling systems were used ( 80 kiloJoule sparker, 500 Joule minisparker and $3.5 \mathrm{kiloHertz}$ transducer) on a 5 to $10 \mathrm{~km} 1 \mathrm{ine} \mathrm{spacing}$ on the shelf and upper slope. In addition, the $R / N$ LEE (L-3-78) cruise made more widely spaced crossings of the continental margin bet ween Dixon Entrance and Cross Sound using a multichannel seismic system, a 500 Joule mini-sparker and a 3.5 kiloHertz transducer ( $f i g \cdot 1$ ).

The seismic lines show evidence for the existence of two fault traces, with the western trace showing the best evidence for recent faulting (fig. 1; Carlson and others, 1979). On lines closest to Icy Point, the eastern fault trace trends directly into the Fairweather fault. The western trace trends seaward of Icy Point, and lines up with a fault inferred, on the basis of onshore and offshore structural features, to lie just offshore along the coastline at least as far northward as Lituya Bay (Plafker, 1967; Bruns, 1979; 1982). There is a 25-degree change of strike at Icy Point between the offshore traces southeast of Icy Point, and the onshore Fairweather Fault and the offshore fault northwest of Icy Point.

The separation between the two sub-parallel fault traces southeast of Icy 


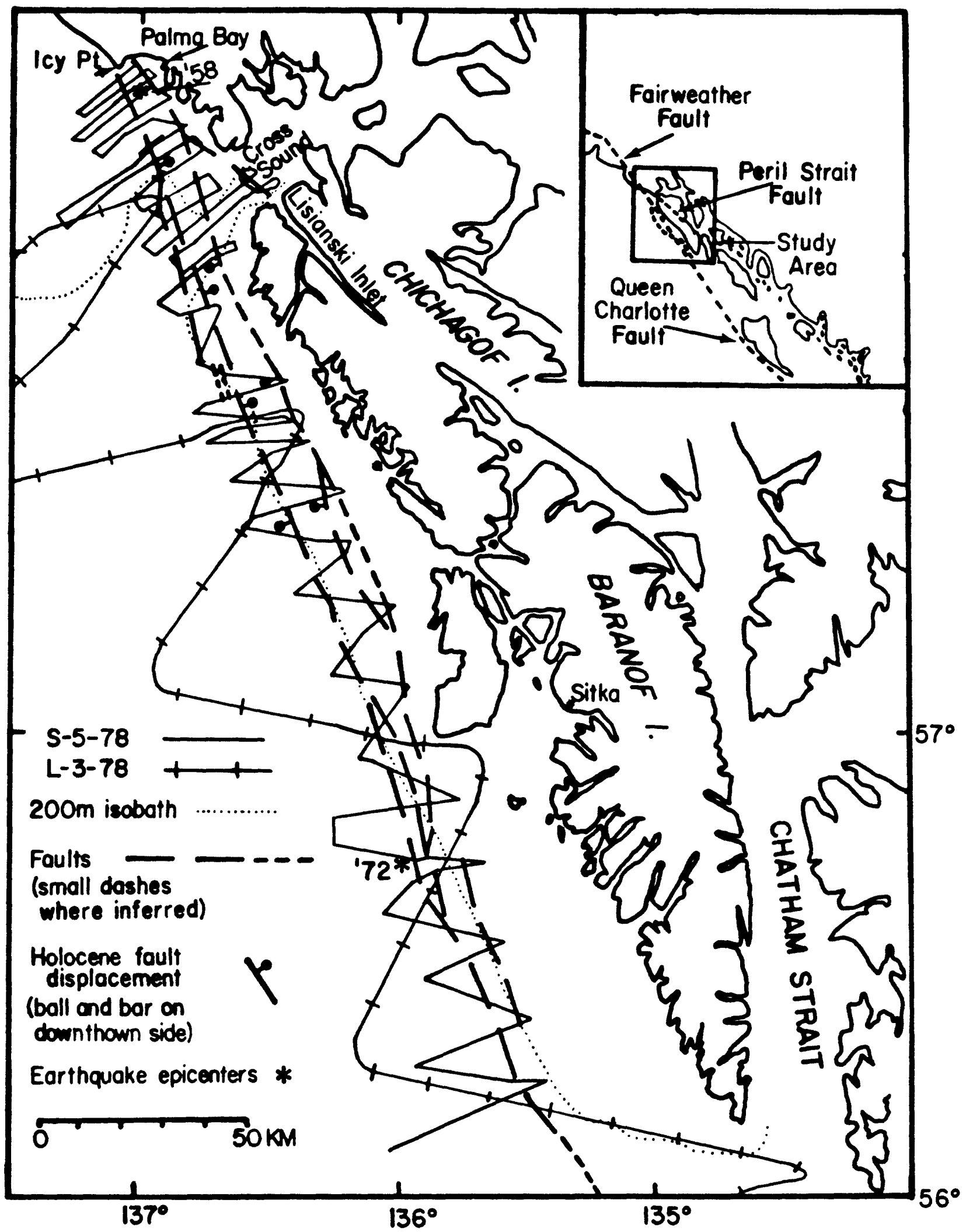

Figure 1. Sketch map of southeastern Gulf of Alaska, showing seaward extension of Fairweather fault system and seismic reflection tracklines. 
Point varies from $6 \mathrm{~km}$ on the seismic line that is about $1 \mathrm{~km}$ from Icy Point to about $12 \mathrm{~km}$ off southern Chichagof Island. These two traces extend across the shelf in a south-southeasterly direction for about $225 \mathrm{~km}$ where they appear to merge on the upper slope southwest of sitka. From this point, our data indicate that the remaining fault trace is present near or seaward of the shelf break and extends along the same trend for at least another $75 \mathrm{~km}$. There is, however, evidence for yet a nother fault trace east of and parallel to the $200 \mathrm{~m}$ isobath that extends for about $40 \mathrm{~km}$ southeast of the epicenter of the 1972 sitka earthquake (fig. 1). This fault trace could possibly connect with the easternmost trace; however, additional seismic lines would be needed in the area west-southwest of Sitka to prove this connection.

Widely spaced multichannel lines (fig. 1) suggest that there is no faulting of late Cenozoic sediments seaward of the continental shelf from Icy Point to the position southwest of Sitka where the two shelf fault traces appear to merge. Southeast of this area, however, features suggestive of faulting are present on the continental slope and near the base of the slope (Bruns and Plafker, this report).

The fault traces mapped on the seismic data are complex, consisting of a number of splays or slivers. At several places where the fault bifurcates or splays, the minor trace forms an arc and appears to rejoin the major trace. An exception to this, however, is about $20 \mathrm{~km}$ southeast of Palma Bay, where the Fairweather fault undergoes a major bifurcation with a branch fault splitting off at an angle of about $35^{\circ}$. This branch fault trends toward Lisianski Inlet, and may connect with the Peril strait fault (Loney and others, 1975).

The offshore faults vary greatly in appearance on seismic profiles from line to line. Some records show well-defined scarps on the seafloor with relief of $25-40 \mathrm{~m}$. Other crossings of the fault trace show no surface offset, but commonly show broken reflectors or abrupt changes in reflector attitudes that are best explained by faulting. Of the two traces, the western one is clearly the better defined and is considerably straighter than the eastern one. Most unequivocal evidence for Holocene displacement, as manifested by seafloor displacements, are on this trace. In most of the crossings of the fault trace where seafloor offsets are well displayed, the sense of movement is northeast-side-down, showing the same sense of vertical displacement as occurred along the onshore Fairweather fault during the 1958 Lituya Bay earthquake (Tocher, 1960). The more sinuous or eastern trace may be an inactive or less active strand of the fault system; however, several of the profiles also showed some seafloor offset along this trace.

The epicenters of the 1972 Sitka and the 1958 Lituya Bay earthquakes are plotted on figure 1. The 1958 epicenter plots just south of Palma Bay between the two fault traces (Sykes, 1971) and was accompanied by displacement on the Fairweather fault for about $300 \mathrm{~km}$ northwest of Palma Bay (Plafker and others, 1978). The 1972 epicenter plots about two $\mathrm{km}$ west of the outer-most fault trace, and focal region (Page, 1973) virtually coincides with the active trace mapped on figure 1 .

The data suggest the westernmost of these continental margin fault traces connects the active Fairweather and Queen Charlotte faults although such a connection implies an apparent complex offset in the vicinity of Palma Bay of 
close to $6 \mathrm{~km}$ between the historically active onshore Fairweather fault and the apparently active offshore fault trace.

Although we have collected no seafloor sediment samples south of Cross Sound, the high resolution seismic profiles from the southeastern Alaska shelf, when compared to profiles and samples from the shelf north of Cross Sound (Molnia and Carlson, 1980), give us some clues to the type of seafloor. Much of the shelf south of Cross sound appears to consist of a hard surface, probably consolidated Tertiary or Mesozoic rocks and perhaps some Pleistocene glacial till, and in a few places such as near Mt. Edgecumbe (west of Sitka) volcanics may crop out on the seafloor. The absence of any large rivers or glacial streams explains the lack of any significant thickness of Holocene fine-grained sediment on the southeastern Alaska shelf. Also the narrowness of the shelf and the erosive effects of the large storm waves that strike this section of the continental margin cause much of the sediment to byypass the shelf. Any sediment bypassing the shelf accumulates on the slope, and is then subject to downslope mass movement.

\section{YAKUTAT SEGMENT}

This segment extends from Cross Sound in the southeast to Icy Bay in the northwest and includes all of the area of lease sale no. 55. Four types of seafloor hazards have been mapped in the Yakutat segment: faults, gas-charged sediment, buried channels, and submarine slides or sediment gravity flows (fig. 2). These hazards were identified on high-resolution seismic-reflection records made with $3.5-\mathrm{kHz}, 400-800 \mathrm{~J}$ minisparker or uniboom, and medium resolution sparker $(20-80 \mathrm{~J})$ systems. Seafloor samples in the areas of potential hazards were collected with cores (gravity cores and vibracores) and grab samples. These data show the sediment distribution and stratigraphic relations and are reported in detail by Carlson and others (1977) and Molnia and Carlson (1978, 1980).

\section{Surface and Near-Surface Faults}

Faults that offset the seafloor or cut strata in the upper few tens of meters of the substrate are shown in figure 3. The near-surface faults develop above deeper structures on the continental margin, as shown by Bruns (1979, 1982).

Near-surface faults are located in four parts of the Yakutat segment: the offshore extension of the Fairweather fault, the Fairweather Ground shelfedge structural high, the shelf edge near Alsek Valley, and the Pamplona zone between Icy Bay and the Pamplona Spur (fig. 2).

The seismically active Fairweather fault borders the northeast part of the study area (fig. 2). This major right-lateral strike-slip fault has been mapped onshore from Yakutat Bay to the shoreline of Palma Bay (Plafker, 1967; Plafker and others, 1978a). The offshore extension of the Fairweather Fault has been mapped by Carlson and others (1979) and is discussed in the southeastern Alaska segment of this chapter.

Fairweather Ground is a topographic and structural high about $1200 \mathrm{~km}^{2}$ in area, located on the outer shelf east of the Alsek Sea Valley (fig. 2). Dredged samples show that the high is cored largely by Mesozoic rocks similar 


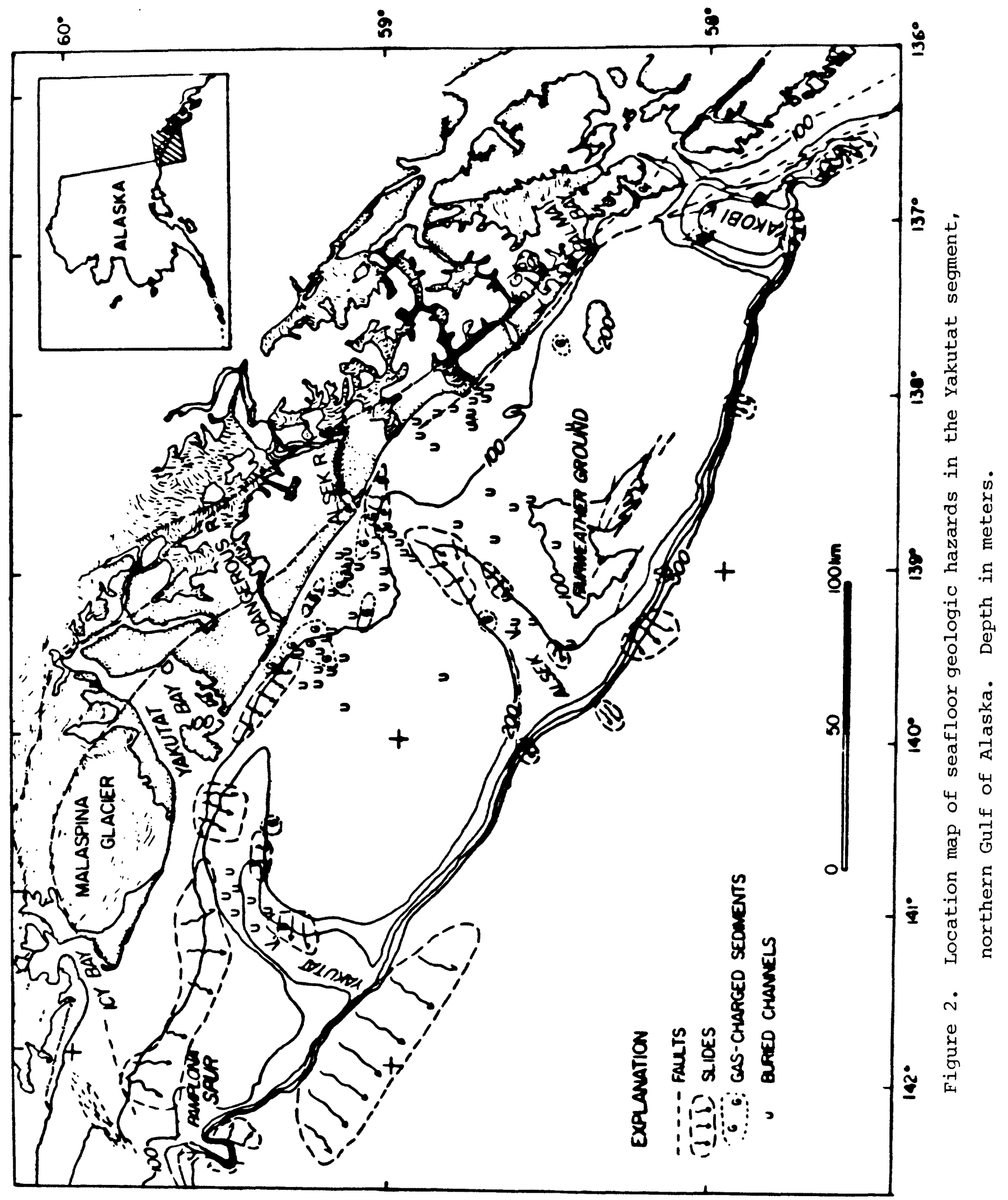


to the Yakutat Group on the mainland (Plafker and others, 1978b, 1980). Dipping seismic reflectors within adjacent rocks of late Cenozoic age flank and onlap the high and indicate significant uplift of the structural high during late Cenozoic time (Bruns, 1979, 1982). This conclusion is reinforced by the presence of steep scarps with relief of up to $60 \mathrm{~m}$ commonly occuring where the rugged Mesozoic rocks crop out on the seafloor. These probable fault scarps trend nearly parallel to the continental slope, and have been mapped discontinuously over a total distance of about $60 \mathrm{~km}$ (fig. 2). The alignments of these scarps suggest at least four individual traces on Fairweather Ground. The irregularity of the outcrops and wide spacing of seismic lines (about $10 \mathrm{~km}$ ) prevent continuous tracing of the probable fault trends.

A solitary fault has been mapped at the shelf edge west of Alsek Valley (fig. 2). No connection is evident between this fault and the multiple traces east of the sea valley. This fault extends in a nearly east-west curvilinear trend for a distance of about $40 \mathrm{~km}$ from the upper slope into Alsek Valley. The fault approximately parallels the northwestern wall of the outer one-third of the valley. Motion on this fault is north- or landward-side up. Although the Alsek Valley fault does not show surface offset, active seismicity is indicated by 49 small earthquakes which occurred in this area between 1974 and 1978 (Lahr and others, 1980).

The Pamplona zone, between Icy Bay and Pamplona Spur, marks the boundary between the structurally simple Yakutat segment of the continental margin and the folded and faulted Yakataga segment to the west (Plafker and others, 1978; Bruns, 1979; Bruns and Schwab, in press; Bruns and Plafker, this report). This zone extends across the shelf and slope from Icy Bay toward the topographically prominent, north-trending Pamplona Spur. Pamplona Spur, a large horstlike structure bounded by north-northeast trending reverse faults, forms part of a zone of a structural uplift that has been mapped to the base of the continental slope (see next section). North of Pamplona Spur, numerous near-surface faults trend north to northeast, parallel to the major structural trends of the Yakataga shelf. The longest of these landward dipping reverse faults have been traced for about $30 \mathrm{~km}$ (fig. 2; Bruns, 1979; Bruns and Schwab, 1982; Bruns and Plafker, this report). Many of these faults are covered by 5 to $10 \mathrm{~m}$ of Holocene sediment. However, at least one high resolution seismic profile shows continuation of a fault upward into the Holocene sediment, but not rupturing the surface. Numerous epicenters of modern earthquakes plot along the Pamplona zone, thus documenting the active nature of these faults (Lahr and others, 1980).

\section{Seafloor Instability}

Three types of potential seafloor hazards involving instability of sediment are present on the continental margin in the eastern Gulf of Alaska: gas-charged sediment, submarine slides and flows, and buried channels. All three hazards are most prevalent in areas seaward of those rivers or streams that carry large quantities of glacially derived sediment to the Gulf, or seaward of the glaciers that at one time crossed the shelf.

Gas-Charged Sediment

Gas-charging reduces the bearing capacity and strength of the 
seafloor sediment (see Lee and Schwab, this report). Six areas of gas-charged sediment have been identified in the eastern Gulf of Alaska between Palma Bay and Cross sound: 1. on the southeast flank of Yakutat Valley, 2. nearshore between the Dangerous and Alsek Rivers, 3. On the west flank of Alsek Valley, 4. southeast of Lituya Bay, 5. on the northwest wall of Yakobi Valley, and 6. southeast of Palma Bay (fig. 2). Seismic profiles of the six gas-charged areas show combinations of displaced reflectors (velocity pullups and pulldowns), wipeouts, acoustic transparency in the top $50 \mathrm{~m}$ of sediment, and occasional gas plumes in the water column (Carlson and others, 1980).;

Gas analyzed from sediment cores collected in these areas, and in gascharged areas to the west, is predominantly biogenic methane (Molnia and others, 1978). Methane concentrations were measured in sufficient quantities to indicate possible gas-charged sediments in one core east of Dry Bay in 1979. The maximum gas concentration was a 32,800 microliters of methane per liter of wet sediment, a gas concentration 3-4 orders of magnitude greater than background.

In each of the six areas, gas-charged sediment is present in the upper part of a thick Holocene sedimentary section. No evidence of leakage from deeper pre-Holocene sources is visible on the high resolution profiles. This observation, as well as the biogenic nature of the gas, suggests that bacterial breakdown of organic material deposited in the rapidly accumulating Holocene sediment is the source of the gas.

\section{Submarine Slides}

Submarine slides and sediment gravity flows have been found in three general areas in this section of the Gulf of Alaska: in nearshore zones, especially off the mouths of rivers, on the walls of sea valleys, and along the continental slope (fig. 2).

The largest slide $\left(1080 \mathrm{~km}^{2}\right)$ on the shelf in the study area is located seaward of Icy Bay and the Malaspina Glacier. Here a process of progressive slumping of Holocene clayey silt is taking place in water depths of 70 to 160 $\mathrm{m}$ on a slope of less than $0.5^{\circ}$. The slump structures are about $0.5 \mathrm{~km}$ long and have reliefs of 2 to $5 \mathrm{~m}$. The slip surfaces extend to a depth beneath the seafloor of 15 to $40 \mathrm{~m}$, and so the volume of the entire Icy Bay-Malaspina slump is about $32 \mathrm{~km}^{3}$. This active landward-growing slump area may be triggered by prolonged ground shaking resulting from the frequent earthquakes in the nearby Pamplona structural zone (Carlson, 1978).

Four smaller areas of mass transport are mapped in the nearshore zone (fig. 2), all of which begin in water shallower than $100 \mathrm{~m}$ i the combined area of all four is less than that of the Icy Bay-Malaspina slump. One slide, southwest of Yakutat Bay begins on the north wall of Yakutat Valley and extends across most of the valley floor covering an area of about $350 \mathrm{~km}^{2}$. This slide incorporates the upper few meters of clayey silt and appears to fit into Varnes' (1978) classification as a mudflow that failed due to lateral spreading. A second slide, which begins $4 \mathrm{~km}$ seaward of the coastline between Yakutat Bay and the Dangerous River, is elongate, about $40 \mathrm{~km}$ long, and about $260 \mathrm{~km}^{2}$ in area. The gradient of the upper part of the slide is about 10 and decreases to about $0.5^{\circ}$ at the seaward edge of the slide. High-resolution profiles across the middle of this slide mass are characterized by a series of 
steplike surfaces with a tread length of about $100 \mathrm{~m}$ and a riser height of 3 to $4 \mathrm{~m}$. Apparent backward rotation of these blocks indicates a true rotational slump movement. The effective depth of the rupture surfaces of these slump blocks is about $10 \mathrm{~m}$, so the volume of slumped material is nearly $3 \mathrm{~km}^{3}$. The third and smallest of the slide masses, $60 \mathrm{~km}^{2}$ in area, is located southeast of the Dangerous River, and begins about $2 \mathrm{~km}$ offshore in water shallower than $20 \mathrm{~m}$. The fourth slide is a $150 \mathrm{~km}^{2}$ area of mass transport just seaward of the mouth of the Alsek River. This slide begins in sand and sandy mud less than $2 \mathrm{~km}$ offshore in about $25 \mathrm{~m}$ of water. This debris flow has moved down the headwall ( 10 slope) to the floor of Alsek valley and has affected the sediment to a depth of 10 to $20 \mathrm{~m}$ (Carlson and others, 1980).

In addition to the slides and flows in the nearshore zone that have entered the upper ends of Alsek and Yakutat Sea Valleys, six smaller slides have been mapped within the three sea valleys (fig. 2). These slides all appear to be mud or debris flow types of mass transport affecting the upper 10 to $20 \mathrm{~m}$ of seafloor sediment and are similar to the debris flow at the head of Alsek Valley.

Numerous areas of sliding and slumping have been mapped on the continental slope (fig. 2). Although most of these slides are immediately seaward of the sea valleys, sliding appears to be a wide-spread mechanism for transporting sediment down the continental slope in the entire Gulf of Alaska (Hampton and others, 1978). More than 80 percent of the U.S. Geological Survey's single channel seismic lines along $1,000 \mathrm{~km}$ of continental slope in the northern Gulf of Alaska show evidence of some type of sliding or slumping (Carlson, 1979). Many of these slides are longer than $5 \mathrm{~km}$ and occur on slopes with gradients of $3^{\circ}$ to $6^{\circ}$. The slides can range from discrete mudflows thinner than $50 \mathrm{~m}$ to complex zones of mass transport several hundred meters thick consisting of multiple slides, such as in the area southeast of Yakobi Valley (Carlson and others, 1982). The large zone of submarine slides seaward of the mouth of Yakutat Valley encompasses $3000 \mathrm{~km}^{2}$ (fig. 2 ). Profiles across this slide area show evidence of mass transport ranging from hummocky surface morphology and broken or disrupted internal reflectors, to down-slope displacement of large blocks. The types of sediment contained in these slides, flows, and slumps are probably of two kinds and two sources. The sediment on the outer shelf is primarily pebbly mud deposited by glaciers that covered the shelf during parts of the Pleistocene. This sediment composes many of the debris flows, slumps, and block glides. The clayey silt composing the maflows predominates on the middle shelf and fine sand predominates on the innermost shelf. Cores taken in sea valleys contain fine sand and silt layers, displaced shallow-water organisms, and some land-derived plant debris indicating the movement of turbidity currents or density flows through the sea valleys. These density flows carry some of the fine sand and mud onto the slope and contributed to the thick sedimentary sections present beneath the slope.

\section{Buried Channels}

A more subtle form of geologic hazard than gas-charged sediment or submarine slides is buried channels. A buried channel commonly is filled by sediment that differs in composition and consolidation from that in the walls of the channels. This creates conditions leading to differential consolidation and, if well-sorted sand and gravel are present in the fill, 
pathwys for fluid migration. These features, which are considered hazards in the North Sea (Fannin, 1979), should also be investigated in the Gulf of Alaska.

Buried channels have been identified in the area between Yakutat Valley and Iituya Bay (fig. 2). Most of these buried channels are concentrated in three nearshore locations, off the Dangerous and Alsek Rivers, and seaward of the Fairweather Glacier. Other buried channels have been identified in Yakutat and Alsek Valleys and on the middle shelf seaward of Fairweather Glacier. No attempt has been made to trace or connect the channels, but the buried channels within Yakutat Valley evidently are connected, as are those in the upper part of Alsek Valley. These buried channels range in size from less than $0.5 \mathrm{~km}$ wide and $25 \mathrm{~m}$ deep to more than $2 \mathrm{~km}$ wide and over $100 \mathrm{~m}$ deep and most appear to have been cut into Pleistocene and older glacial sediment (Carlson and others, 1982). As the glaciers retreated, a large number of melt-water streams flowed across the shelf. Some buried channels show evidence of scour and fill, and several larger channels have small channels nested within them.

In addition to the buried channels marked on the map (fig. 2), the three sea valleys are being filled with Holocene sediment (Carlson and others, 1982; Molnia and Carlson, 1980). This fill also could create differential settlement problems and must be carefully analyzed before any seafloor structures such as pipelines are built across the fill.

\section{YAKATAGA AND MIDDLETON SEGM ENTS}

The Yakataga segment of the Gulf of Alaska continental margin extends from Icy Bay to Kayak Island and the Middleton segment extends from Kayak Island to Montague Island. Together these two segments make up the bulk of the area offered in OCS sale 39. Three types of seafloor geologic hazards have been mapped in the Yakataga and Middleton margin segments: faults, gascharged sediment, and submarine slides or slumps (figs. 3 and 4 ).

\section{Surface and Near-surface Faults}

The general trend of the near-surface faults in the study area is northeast-southwest to east-west, subparallel to major onshore structures (Plafker, 1967). These near-surface faults are related to the development of the deeper structures on the continental margin as shown by Bruns (1979) and Bruns and Schwab (1982).

Near-surface faults thus far detected are located in four main parts of the Yakataga-Middleton margin: 1. south of Cape Yakataga, 2. on or adjacent to the Kayak Island platform, 3. on Tarr Bank and 4. near Middleton Island. In most cases the faults cut strata wich are of late Cenozoic age (Carlson and Molnia, 1977). Commonly these strata are covered only by a thin veneer of Holocene sediment and in many places crop out at the seafloor. A few of the faults appear to cut Holocene sediments, but none were found that unequivocally offset Holocene sediment at the seafloor.

Several near-surface faults trend northeast-southwest parallel to the major Icy Bay structural trends (Bruns, 1979; Bruns and Schwab, 1982) south of Cape Yakataga. The two longest of these faults can be traced for about $30 \mathrm{~km}$ 


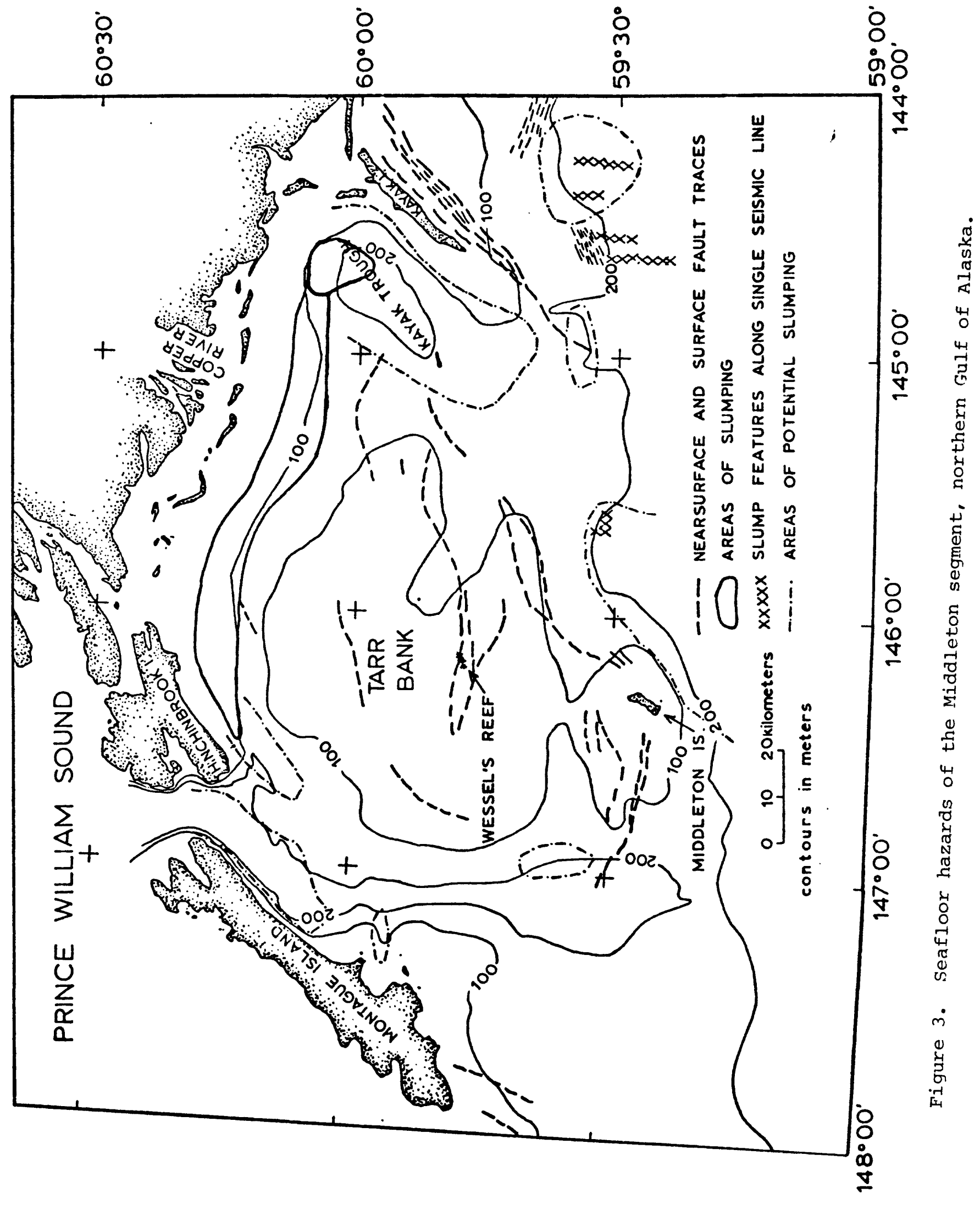




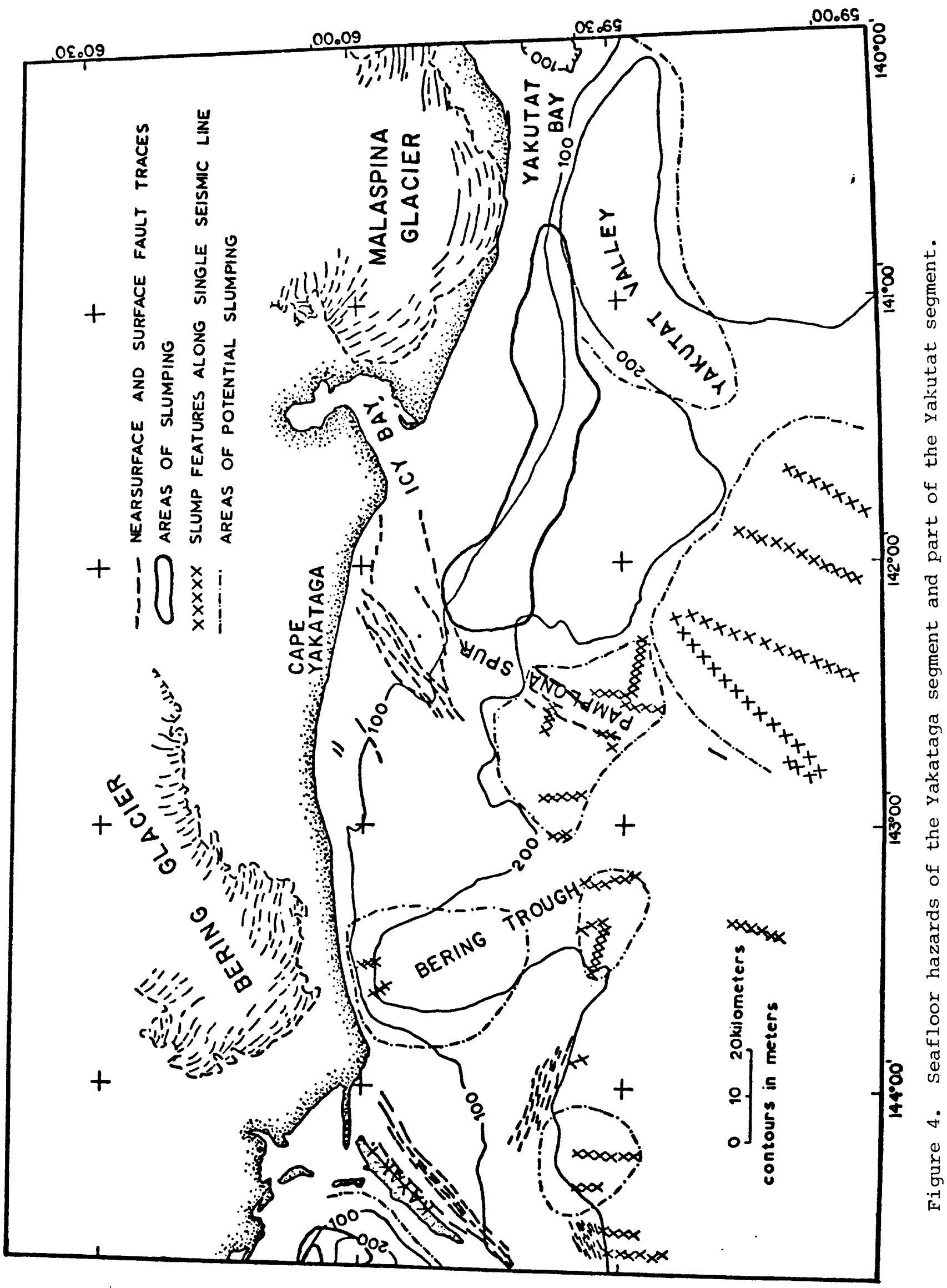


(fig. 4). The sense of motion is up on the northwest. Most of these faults are covered by 5-10 m of Holocene sediments and in one case one of the faults may continue upward into the Holocene sediments, but does not appear to break the surface.

Swarms of small discontinuous step faults were found along several seismic lines at the outer edge of the continental shelf south of Kayak Island (fig. 4). Tertiary strata are disrupted at the seafloor and the relief along these numerous scarps is about 2-5 $\mathrm{m}$. These scarps may delineate slump blocks at the edge of the shelf. Along some of the profile lines, masses of what appear to be slumped sediment are seen on the slope. Some of the blocks show evidence of backward rotation; however, the seismic records do not show outward curvature of the fault or slip planes.

The longest near-surface faults in the Yakataga-Middleton segment are southeast of Kayak Island (fig. 3 and 4 ). The seaward side of this fault zone extends southwest of Cape suckling and cuts Tertiary strata and perhaps the lower part of the overlying 10-20 m of Holocene sediment. Disrupted reflectors on minisparker profiles indicate gas-charged Holocene sediment along part of the fault trace. The gas could be methane-generated within the Holocene sediment or it could be gas liberated from underlying reservoir rock that has migrated up the fault plane into the surficial sediment. This fault zone nearly parallels Kayak Island, probably includes Plafker's (1974) 10 Fathom fault, and continues southwest along the Kayak platform. The total length of this near-surface fault zone is approximately $70 \mathrm{~m}$. This fault has a sense of motion of up on the northwest.

Northeast of Middleton Island, a 50-km-long curving complex fault zone (fig. 3) cuts Tertiary strata. The middle part of this fault zone reaches the seafloor, but at each end the faulted strata are covered by a thin veneer (5$10 \mathrm{~m}$ ) of Holocene sediment. The relative motion is up on the north side.

The most prominent, clearly fault-associated scarp is located on Tarr Bank and has a relief of about $20 \mathrm{~m}$. This fault, which is upthrown on the north side, also has been recorded on 3 other lines (offsets of the seafloor vary from 5-10 m) and is at least $18 \mathrm{~km}$ long. Bonilla and Buchanan (1970) have plotted lengths of historic surface faults (from all parts of the world) versus surface displacements and their graph suggests that a fault with $20 \mathrm{~m}$ of displacement should be nearly $600 \mathrm{~km}$ long in order for that amount of displacement to have occured as a single event. Five meters of displacement requires a fault length of over $100 \mathrm{~km}$. Conversely, the amount of displacement expected along a $20 \mathrm{~km}$ fault is less than $1 \mathrm{~m}$. It appears, therefore, that episodic movement is required to account for the 5-20 m of displacement. This fault with $20 \mathrm{~m}$ of relief is associated with several other faults branching from the Wessels Reef complex on Tarr Bank (fig. 3), extending the overall length to $35 \mathrm{~km}$ (maximum single event displacement is approximately $1.5 \mathrm{~m}$ ). Three seismic events (all less than magnitude 4 earthquakes) recorded in the period september 1974-May 1975, whose epicenters were plotted in the vicinity of the Wessel Reef fault complex (Iahr and Page, 1976), emphasize the currently active nature of these faults. These faults offset the seafloor, which appears to be folded and truncated late Cenozoic rock (Carlson and Molnia, 1977).

A series of east-west-trending faults of varying lengths cut the folded, 
truncated Tertiary and Pleistocene strata west of Middleton Island (fig. 3). The southernmost of these faults is more than $30 \mathrm{~km}$ long, and identified on six separate seismic lines. The relative movement along these faults appears to be north side up.

Submarine slides and Slumps

Seismic profiles from two parts of the study area seaward of the Copper River and of Icy Bay (figs. 3 and 4) show disrupted bedding and irregular topographic expression commonly associated with submarine slides and slumps. Some of the disrupted reflectors perhaps are due to the presence of gas-charged sediment. These reflectors are very similar to those off Kayak Island. However, all along the Copper River prodelta, which has a gradual slope of less than one-half degree, the seismic profiles showed zones of a second type of disrupted or discontinuous reflector in the Holocene sediments (Carlson and Molnia, 1977). The Copper River prodelta was investigated with seismic profiling equipment by Reimnitz (1972) shortly after the 1964 Alaskan earthquake. He attributed slump structures seen on highresolution seismic records to this earthquake. These structures are similar in size and shape to the structures visible on our profiles over this same area. These slump structures show progressive failure due to lateral extension of a sedimentary unit at the base of the slump blocks. We conclude that these structures were probably created by the intense ground shaking that accompanied the 1964 Alaskan earthquake. These structures are present over an area of about $1,730 \mathrm{~km}^{2}$ that extends about $20 \mathrm{~km}$ offshore between Hinchinbrook Island and Kayak Island (fig. 3 ).

The Copper River is a major source of Holocene sediment in this region, annually supplying $107 \times 10^{6}$ tonnes of detritus (Reimnitz, 1966). Much of this sediment has accumulated on the prodelta, reaching a maximum thickness of $355 \mathrm{~m}$ southeast of the main channel and averaging about $150 \mathrm{~m}$ thick across the entire prodelta (Carlson and Molnia, 1975). In regions with high rates of sedimentation such as the Copper River delta, the lag between accumulation and consolidation gives rise to excess pore pressure, and the sediment is prone to sliding (Hampton and others, 1978).

The most spectacular example of mass movement in this study area is a large submarine slide located at the eastern edge of the Copper River in the Kayak Trough (fig. 3). This slide has a length of $17 \mathrm{~km}$, a maximum width of $12 \mathrm{~km}$, and a maximum thickness of about $115 \mathrm{~m}$. The estimated volume of material affected by this slide is approximately $5.9 \mathrm{~km}^{3}$ (Carlson and Molnia, 1977; Molnia and others, 1977). In addition to very irregular surface morphology and disrupted internal reflectors, this slide has a fairly well preserved pull-apart scarp with a relief of about $10 \mathrm{~m}$ and a well-developed toe that is $20 \mathrm{~m}$ thick about $2 \mathrm{~km}$ from the distal end. The toe of the slide is partly buried, suggesting erosion of the underlying sediment as the slide moved down the one-degree slope into Kayak Trough; post-slide deposition also accounts for some of the sediment cover. Apparently there was enough momentum at the toe of the slide to carry it past the thalweg of the trough, imparting to the surface a very slight upward concavity (Carlson and Molnia, 1977).

Sediment samples collected with a box corer from the upper $50 \mathrm{~cm}$ of the surface of this slide consisted of gray clayey silt that was seemingly structureless. However, X-radiographs of slabs of the sediment revealed 
contorted disturbed bedding, some crossbedding, and chaotic mixtures of irregular fragments of various shapes. The sediment was extremely weak as shown by sediment flowge when the box cores were opened on board ship to permit description and subsampling, and by laboratory tests with a vane shear apparatus that yielded a peak shear strength of $0.02 \mathrm{~kg} / \mathrm{cm}^{2}$.

The second large area of disrupted reflectors indicating slides or slumps is just seaward of ICY Bay and covers about $1,770 \mathrm{~km}^{2}$ of the seafloor (ifig. 4). The slope is gradual $\left(\left\langle 1 / 2^{\circ}\right)\right.$, but the Holocene sediment reaches a thickness of more than $150 \mathrm{~m}$ (Carlson and Molnia, 1975). The source of much of the sediment is probably the Malaspina Glacier. Sediment-laden meltwater from this huge piedmont glacier flows into the Gulf of Alaska and is moved westward by counter-clockwise flow of the Alaskan Gyre (Reimnitz and Carlson, 1975).

In addition to areas in the ocs where slump or slide structures were seen on the seismic profiles, we have mapped areas that appear to be potential slide or slump zones (fig. 3 and 4 ). Delineation of these potentially hazardous areas is based on thickness of Holocene sediment and relative steepness of slope. Slump or slide features were not prominent on the profiles. However, because of the sediment thickness (>25 $\mathrm{m}$ ) and slope steepness $\left(>1-8^{\circ}\right)$ there is a possibility of ground failure in these areas if a large earthquake provides a long duration of rapid ground acceleration or if large tsunamis or storm waves disrupt the seafloor. 


\title{
CHAPTER V
}

\author{
GEOTECHNICAL INVESTIGATIONS RELATED TO \\ GEOLOGICAL HAZARDS: NORTHERN GULF OF ALASKA
}

by

Homa J. Lee and William C. Schwab

\section{INTRODUCTION}

Systematic study of the sediment distribution, depositional environments, and shallow structure of the northeast Gulf of Alaska began in 1974 when the U.S. Geological Survey began petroleum-related regional hazards analysis. This chapter summarizes geotechnical work completed and in progress on the continental shelf between Montague Island and Cross Sound, Gulf of Alaska (fig. 1).

The complex Quaternary history of the northeast Gulf of Alaska has generated a variety of sedimentary deposits. Four major sedimentary units are defined on the basis of seismic reflection and sedimentologic data: 1. Holocene glacial-marine sediment; 2 . Holocene end morainal deposits; 3 . Quaternary glacial deposits; and 4. Pleistocene and older lithified sedimentary rocks (Carlson and Molnia, 1975; Molnia and Carlson, 1975; 1978; Carlson and others, 1977; Molnia and Sangrey, 1979; Molnia and Carlson, 1980) (fig. 2).

Seafloor geologic hazards in the northeast Gulf of Alaska are summarized in Carlson and Schwab (this report) and have been described by Carlson and others (1975), Carlson and Molnia (1977), Molnia and others (1977), Carlson (1978), and Carlson and others (1980). The hazards include: 1. submarine slides and flows; 2 . shallow faults; 3 . gas-charged sediments; and 4 . buried channels. Active faulting is well documented using conventional geophysical techniques (Bruns, 1979, 1982; Bruns and Schwab, 1982; Carlson and Schwab, this report). Buried channels involve sediment and sedimentary rocks that are too deeply buried to be sampled with conventional coring equipment and therefore have not been studied in detail.

Detailed study of seismic reflection records and sediment samples in areas of sediment instability show a variety of geologic conditions responsible for submarine slides and flows. Geotechnical measurements from core samples, along with estimates of geologic forces, have been used for engineering analysis to test the conclusions made from the geologic data and to identify the significant environmental parameters responsible for the instability. Insight into the mechanics of submarine sliding gained from these studies contributes to the development of models to evaluate the potential for sliding in areas of suspected instability.

The geotechnical studies have been directed almost exclusively toward slope stability in the Holocene glacial-marine sediment. Holocene morainal sediments, Quaternary glacial sediments, and Pleistocene and older lithified sedimentary rocks are predominantly dense and hard, reflecting glacial ice loading. These compacted deposits are probably not susceptible to sliding. In contrast, the Holocene glacial-marine sediments are weak, soft, well 
stratified, greenish-gray clayey silt and sandy silt that grade to fine sands in the nearshore. In this area of frequent earthquakes (Lahr and Page, 1977) and large storm waves (Royer, 1977), materials such as the Holocene glacialmarine sediment are susceptible to slope failure under cyclic loading.

Gas-charging, although present in the northern Gulf of Alaska, is not nearly as widespread as sliding. In addition, the sampling and analytical techniques needed to quantitativly assess gas-charged sediment as a geologic hazard have not been fully developed.

\section{INVESTIGATIONS}

Two cruises in 1977 (aboard the $R / V$ Sea Sounder and $R / V$ Discoverer) yielded about 50 sediment cores between Yakutat Bay and Montague Island that were analyzed for geotechnical behavior. All cores were tested for vane shearing strength, water content, bulk density, and grain size distribution. Many of the cores were also tested by contractors for static triaxial shearing strength and one-dimensional compressibility. The testing contractors were Geotechnical Engineers, Inc. (1978), Law Engineering Testing Company (1978), and the University of California, Berkeley.

In 1980, a series of in situ geotechnical engineering tests were conducted from the $R / V$ Discoverer between Icy Bay and the Alsek River, using a Multi-purpose In Situ Test System (MITS) leased from Woodward-Clyde Consultants. The tests included cone penetration and vane shear with maximum penetration of about $6 \mathrm{~m}$. About 30 gravity cores were taken in the same area and tested for index properties and laboratory vane shearing strength. Several of the cores were tested for triaxial shearing strength (cyclic and static) and compressibility by Law Engineering Testing Company (1981) and the U.S. Geological Survey. In 1981, a set of vibra-cores and additional gravity cores was taken near the locations of the in situ tests of 1980. The vibracores were used primarily to provide stratigraphic control for analyzing the in situ test results.

\section{RESULTS}

Some of the geotechnical results from the two 1977 cruises were reported by Hampton and others (1978), Carlson and others (1978), Molnia and Sangrey (1979), and Sangrey and others (1979). A complete tabulation of all of the results will be available in a U.S. Geological Survey open-file report scheduled for completion in late 1982.

The glacial-marine depositional environment is characterized by sediment transported into the ocean system by meltwater streams, by ice rafting, or from flowing ice sheets. The Holocene glacial-marine sediment consists of well-stratified silty-sand in water depths less than about $40 \mathrm{~m}$ (nearshore zone) and clayey silt (208 to 608 clay content) in deeper water (Carlson and others, 1980). At the sand-silt transition (about $40 \mathrm{~m}$ ) cores contain layers of fine sand and silt. Down core variations in index properties (water content, vane shear strength, and grain size distribution) are often greater than variations in the average properties between cores. However, there is a general tendency toward an increase in water content and clay-size content with distance offshore. The increase in water content is reflected in lower vane shear strengths and increased plasticity. 
Earlier publications, for example Sangrey and Molnia (1979), have suggested that underconsolidation is a significant factor leading to unstable sediment in the northern Gulf of Alaska. Underconsolidation results from a combination of high sedimentation rates and low permeability and leads to high excess pore pressures and unusually low shear strengths. Underconsolidation almost surely exists in the embayments such as Icy Bay (sedimentation rate of $2000 \mathrm{~mm} / \mathrm{yr}$ ) or Lituya Bay (sedimentation rate of $3750 \mathrm{~mm} / \mathrm{yr}$ ) where measured sedimentation rates are among the highest in the world (Molnia and others, 1980). In the open portion of the shelf, between Icy Bay and the Alsek River, however, in situ vane shear data from the 1980 field season indicate that much of the Holocene glacial-marine sediment is normally consolidated.

Figure 3 shows all of the in-place vane shearing strength profiles in the glacial-marine silt (locations in Table 1) and an estimate of the overburden stress distribution. The ratio of strength to overburden stress in the lower portion of the profiles ranges from 0.4 to 0.7 . From consolidated-undrained triaxial tests performed on core samples from the same locations, the ratio of strength to vertical consolidation stress for normally consolidated conditions was found to be 0.3 to 0.7 . If underconsolidation were present, the strengthto-overburden stress ratio in-place would be much lower than the laboratory value for normal consolidation.

With the exception of the embayment areas, therefore, underconsolidation does not appear to be widespread or a cause of the many documented landslides. Instead, the tendency of some of the glacial sediment to lose significant strength during cyclic loading appears to be a major factor in generating these slides. Cyclic triaxial tests show a loss of strength of from 208 to 708 with 10 cycles of loading for the Holocene glacial marine silt. By using a simplified seismically-loaded slope stability analysis (Lee and others, 1981), these results indicate that pseudo-static earthquake accelerations of 0.07 to $0.2 \mathrm{~g}$ may be sufficient to cause failure. Peak accelerations in this range are common in seismically active areas. For example seed and others (1975) report peak accelerations of $0.1 \mathrm{~g}$ at $45 \mathrm{~km}$ from the epicenter of a magnitude 6.5 earthquake. Therefore earthquake loading of some Holocene glacial marine silts is probably sufficient to cause failure even if the sediment is in a normally consolidated state.

The susceptibility of the sediment to strength loss during cyclic loading correlates fairly well with water content. The glacial marine silt with water contents ranging from 358 to 458 dry wight is the most susceptible to strength degradation and appears to be the material that will fail with pseudo-static earthquake acceleration of less than $0.1 \mathrm{~g}$. Most of the silt with this water content range occurs immediately seaward of the sand-silt transition zone and extends 10 to $15 \mathrm{~km}$ farther offshore. Almost all of the observed landslides on the shelf fall in this zone (Carlson and Molnia, 1977, Carlson and others, 1980).

The sand deposits shoreward of the transition zone have not been evaluated to any great extent. A preliminary evaluation of in-place static cone penetration test results indicates that relative densities of the sands near the mouths of the Dangerous and Alsek rivers are between 808 and 1008 . Sands as dense as these would probably not be vulnerable to liquefaction during wave or earthquake loading. However, this conclusion is based on sparse data and should at some point be evaluated with further testing. Also, 
because failure features are not retained for long in a sandy bottom, it is possible that failures have occured in the past and are no longer observable with acoustic profiling techniques.

In summary, geotechnical investigations of the Holocene glacial marine sediment tentatively show the nearshore sands to be relatively stable and insensitive to cyclic loading. The silt immediately seaward of the sand-silt transition (near $40 \mathrm{~m}$ ) appears to be highly susceptible to cyclic loadíng and likely to fail during earthquakes. Further offshore the sediment is finer grained and has a higher water content. This material is less likely to fail during cyclic loading even though its static strength is relatively low.

To further investigate the validity of these findings three investigations of special study areas are presently underway. The study areas include a massive sediment slide and flow area offshore of the mouth of the Alsek River (Molnia and others, 1978; Molnia, 1979; Molnia and Rappeport, 1982), a large series of slump blocks off the Malaspina Glacier (Carlson, 1978) and a smaller slump area directly off Yakutat. A goal of the work will be to determine which combinations of basic sediment state, grain size, fabric and other factors lead to observed failure conditions and which do not. 
Table 1. Locations of In-Place Vane Shear Tests

Site

Number

Description

Longitude

Latitude

Alsek Delta

Off Yakutat

Yakutat Sea Valley

$138^{\circ} 44.31^{\prime} \mathrm{W}$

$139^{\circ} 48.40^{\prime} \mathrm{W}$

$140^{\circ} 19.1^{\prime} \mathrm{W}$

off Malaspina Glacier

$141^{\circ} 23.4^{\prime} \mathrm{W}$

$59^{\circ} 6.99^{\circ} \mathrm{N}$

$59^{\circ} 28.21$; N

$59^{\circ} 36.5^{\prime} \mathrm{N}$

$59^{\circ} 36.6^{\prime} \mathrm{N}$ 


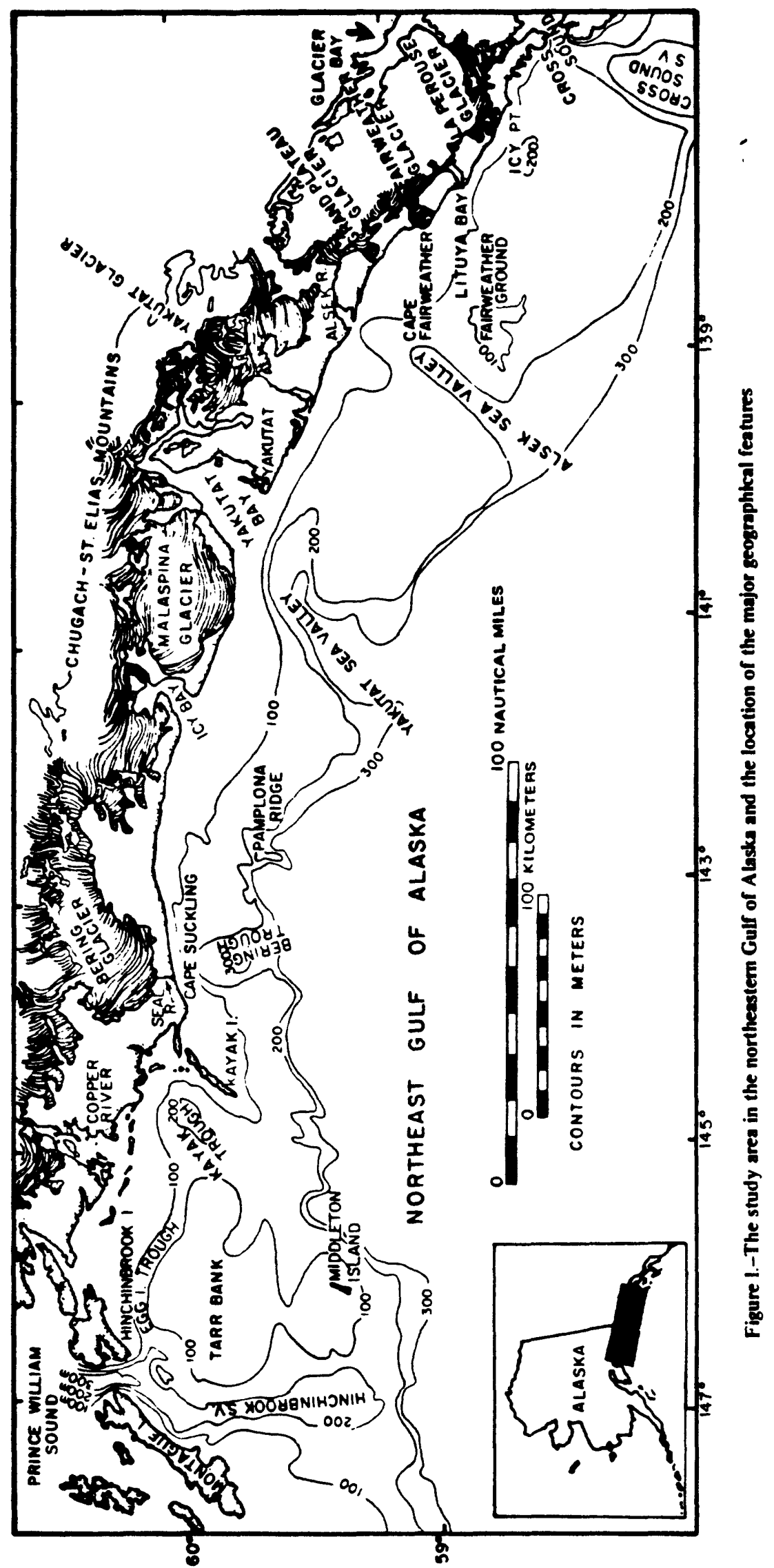




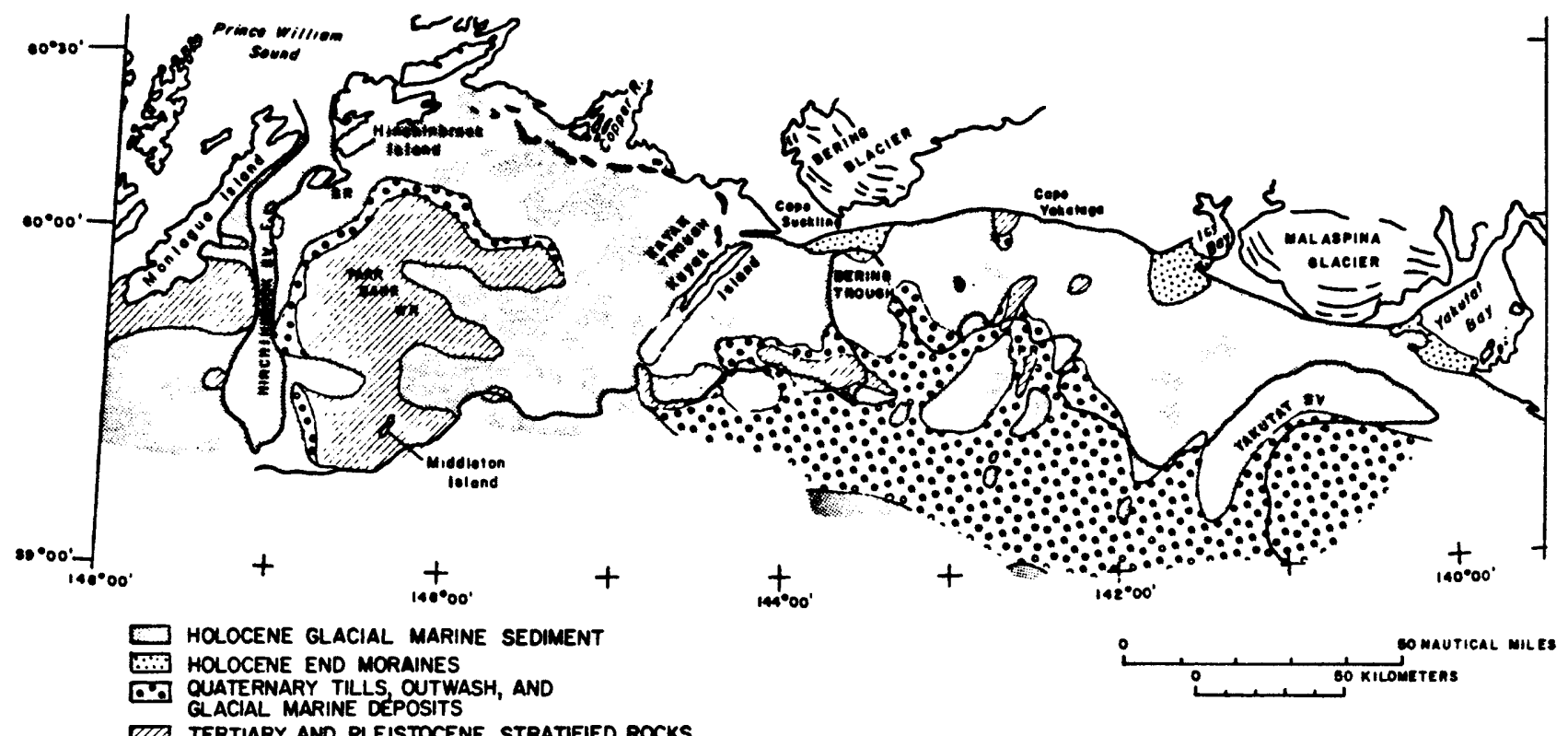

DIA TERTIARY AND PLEISTOCENE STRATIFIED ROCKS

- 200 METER ISOGATM

Fig. 2 - Map of the distribution of the four surface stratigraphic units on the shelf between Montague Island and Yakutat Bay. 


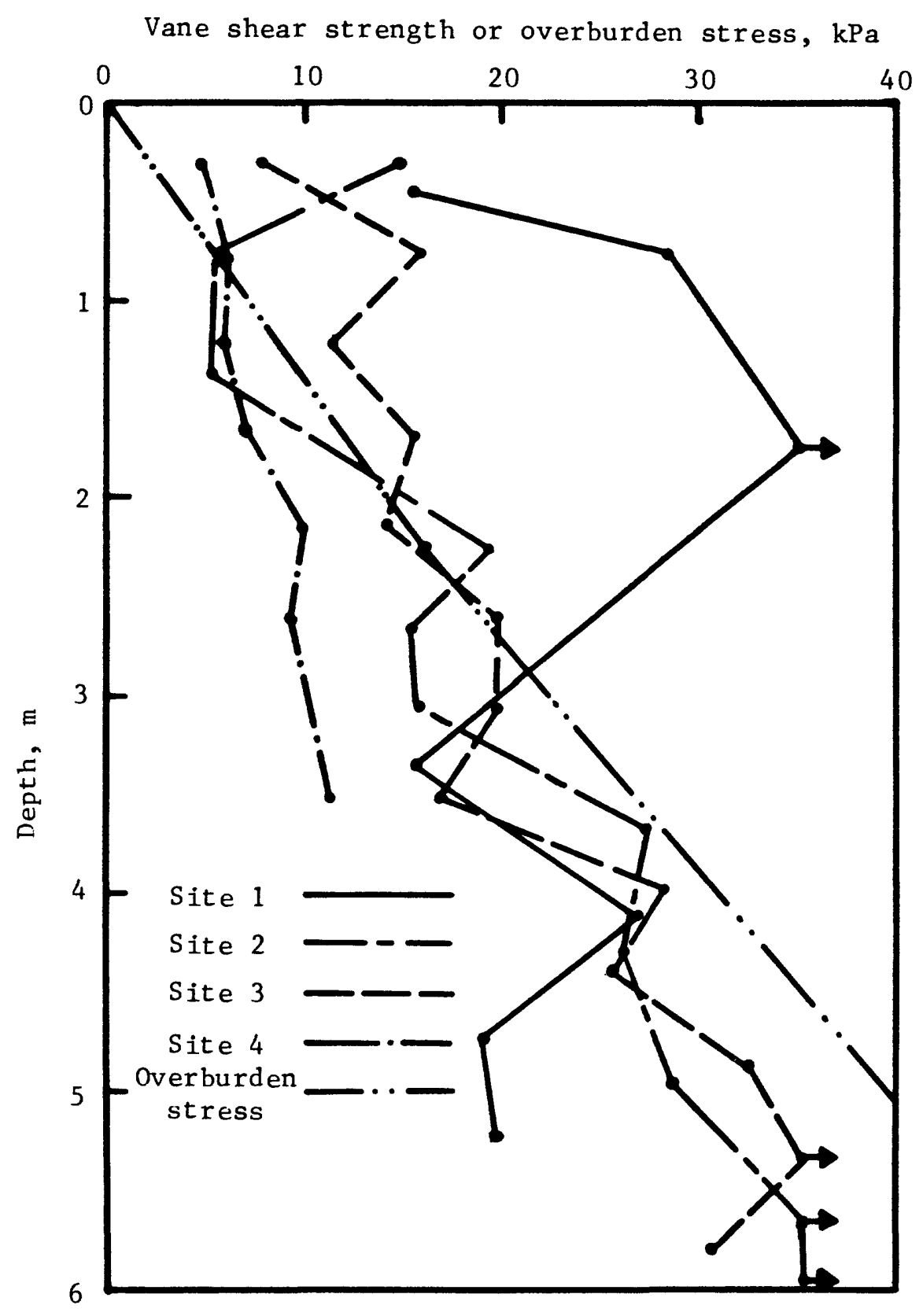

Figure 3. In place vane shear strength profiles 
CHAPTER VI

LOWER COOK INLET ENVIRONMENTAL GEOLOGY

by

Monty A. Hampton

INTRODUCTION

Cook Inlet is a large, tidally dominated embayment extending $300 \mathrm{~km}$ northeast from the Gulf of Alaska to Anchorage. From 1976-1979, over $5000 \mathrm{~km}$ of seismic reflection lines were run in the lower inlet. Seismic systems used included 30-160 kilojoule sparker, Uniboom, minisparker, 3.5 kilohertz, 12 kilohertz and side-scanning sonar systems. More than 20 hours of underwater television and $70 \mathrm{~mm}$ bottom photography were conducted. Samples of seafloor sediment were collected at 116 stations, mostly using a modified van Veen sampler and a few using a gravity corer and a vibracorer. Profiling current meter readings were also taken at 3 locations.

This section is a sythesis of geologic information of environmental importance to resource activities in lower cook Inlet. For a more detailed discussion of the environmental geology, refer to the recent report by Hampton (1982). A number of geologic hazards have been identified that pose potential problems to future installations within lower cook Inlet and along the adjacent coastline. However, oil and gas exploration has been conducted safely for several years in the adjacent upper cook Inlet, which shares similar coastal and marine environments.

A detailed bathymetric map of lower cook Inlet has been presented by Bouma and others (1978) (fig. 1). As can be seen on the map, the northern part of lower cook Inlet contains an elongate trough that bifurcates around Kalgin Island and contains closed depressions. The trough is flanked by shallow platforms adjacent to land on the east and west sides. South of the trough is a triangular-shaped plateau, and adjacent to the plateau on the west is an arcuate or $v$-shaped ramp that divides the relatively shallow northern area from the deeper area to the south. The top of the ramp is at about $70 \mathrm{~m}$ water depth, and the base is at about $115 \mathrm{~m}$. South of the ramp, lower cook Inlet slopes rather uniformly into Shelikof strait. To the east, the bathymetry shows a complicated array of local highs and lows, but the basic physiographic elements include troughs in Stevenson and Kennedy Entrances that are separated by a slope around the Barren Islands and by a ridge to the southeast.

\section{SEISMICITY AND TECTONISM}

Lower Cook Inlet is situated near the convergent margin of the North America and Pacific lithospheric plates. Modern tectonism is evident from the frequent strong earthquakes in the area; 13 events of greater than magnitude 6 have occurred within the lower cook Inlet area in the last 65 years. Seismic activity certainly poses the major environmental risk. Lower cook Inlet is included in seismic risk zone 3, defined as areas susceptible to earthquakes exceeding magnitude 6 and where major structural damage could occur (Evans et al,. 1972). Damage can either be caused directly by ground 
shaking, surface faulting, or surface warping, and indirectly by ground failure or tsunamis.

The recurrence interval of great earthquakes $(M>7.8)$ in the cook Inlet area has been estimated from a minimum of 33 years (Sykes, 1971) to a maximum of 800 years (Plafker and Rubin, 1967). These earthquakes are generated in the shallow thrust zone, less than $30 \mathrm{~km}$ deep, associated with plate convergence. Deeper earthquakes, with frequent events in the magnitudé 5-6 range, show clusters beneath Iliamna, Douglas, and Augustine volcanoes (Pulpan and Kienle, 1979). Intense shallow events associated with volcanic eruptions have also been recorded.

The last great earthquake to affect the Inlet occurred in 1964, and considering the minimum estimated recurrence interval, another from the same source area might happen during the lifetime of an oil-producing province. The Shumagin seismic gap directly to the west is another source area predicted for a near-future great earthquake (Pulpan and Kienle, 1979). So, although the timing of destructive earthquakes cannot be predicted precisely, they must be considered a threat during resource development in lower cook Inlet.

The 1964 Alaska earthquake caused tectonic warping of the earth's surface over a broad region. Maximum uplift of 15 meters was reported in the eastern Gulf of Alaska (Malloy and Merrill, 1972). General subsidence occurred in and around lower Cook Inlet, to a maximum of $1.3 \mathrm{~m}$ (Plafker, 1972). Along Homer Spit, sediment failure and consolidation augmented the subsidence to a total of nearly $2 \mathrm{~m}$, submerging large areas of land (Waller, 1965). Tectonic warping can change the elevation of coastal or offshore facilities enough to affect their operation.

Details of the effects of large earthquakes offshore in cook Inlet are unknown, but no sediment slides or major shallow faults have been found, and they are not considered to be a significant problem. Knowledge of unconsolidated sediment types is limited to near-surface samples, and it is possible that engineering test drilling will reveal local subsurface sediment layers that could liquefy during a seismic event. Nevertheless, ground shaking, tectonic ground warping, and perhaps tsunamis appear to be the major offshore concerns from seismic activity.

Shallow faults are short and nearly uniformly distributed, except for concentrations near the Barren Islands and between Augustine Island and Cape Douglas (fig. 2). Those faults that offset unconsolidated sediment have moved since pleistocene time, but their most recent movement is unknown. Recent activity has occurred on the Castle Mountain fault, a short distance northwest of the inlet, as shown by lineations and of fset of pleistocene glacial deposits (Evans et al., 1972). After the 1964 earthquake, Foster and Karlstrom (1967) mapped an extensive zone of ground fissures adjacent to the southeast margin of upper cook Inlet and suggested that the zone might be underlain by an active fault. Pulpan and Kienle (1979) report some linear shallow seismic trends in Cook Inlet, but no correlations with known faults have been made. 


\section{VOLCANISM}

Four active volcanoes are located along the northwest margin of Cook Inlet. All but Mt. Douglas have erupted in historic time. The most recent eruption was that of Mt. Augustine in 1976. The volcanoes are andesitic and can explode violently. Severe danger from lava flows, nuee ardentes, or lahars is probably restricted to land and coastline areas around the volcanoes, although in the unlikely event of a krakatoan eruption of insular Mt. Augustine, major effects could be felt at sea. Abrasive and corrosive effects of ash falls from typical eruptions can extend regionally and be a nuisance, if not a major danger, to offshore operations. A destructive tsunami associated with the 1883 eruption of Augustine volcano reportedly hit the east side of the inlet (Evans et al., 1972), and similar tsunamis could affect coastal areas in the future.

\section{SEDIMENTARY PROCESSES AND DEPOSITS}

The thickness of unconsolidated sediment over bedrock ranges from less than $20 \mathrm{~m}$ to about $340 \mathrm{~m}$ (fig. 3 ). The deposits consist of coarse-grained glacial material that has been reworked and redistributed by Holocene marine processes (Rappeport, 1981; Sharma and Burrell, 1970).

The present-day sedimentary environments in lower cook Inlet range from quiet areas of sediment accumulation in some coastal and deep-water areas to active areas of intense sediment transport in others. Knowledge of the distribution of sediment types and processes has several environmental applications to engineering foundation design and to prediction of pollutant transport pathways and storage sites.

Surficial sediment types range from sandy silt to gravel (fig. 4) and appear to possess good foundation properties. Geotechnical tests have not been run to determine shear strength and consolidation behavior, but the coarse-grained nature of the sediment (typically with small amounts of clay), the general low accumulation rates, and the low seafloor slopes throughout most of the area imply favorable engineering conditions. No geologic evidence of gravitationally unstable slopes or soft, underconsolidated sediment has been found. As mentioned previously, subsurface layers of liquefiable silt or fine sand may exist that could cause strength loss or abnormal consolidation during an earthquake, but their presence can only be determined by drilling.

Environmental problems may arise in association with sediment dynamics and related ocean currents. Tides generate the dominant flow in lower Cook Inlet. Tidal currents of 2 to 4 knots have been measured in the western portion of the inlet (Rappeport, 1981). Also, storm waves occasionally produce significant currents that can reach velocities greater than $20 \mathrm{~cm} / \mathrm{sec}$ in water depths of at least $50 \mathrm{~m}$.

The extensive sand-wave fields are of particular interest (Bouma and others, 1979; orlando, 1982; fig. 5). These large bedforms occur in the central, moderately deep areas of the seafloor where sand is abundant. Migration of the large sand waves in response to the strong ocean currents that form them could cause removal of support from structures or applicaiton of unexpected loads. Migration rates are most likely negligible during normal conditions, as determined by two independent studies (Rappeport, 1981; Whitney 
and others, 1979), but short-lived extreme conditions might induce significant movement because sediment transport rate increases with the third power of mean current velocity (e.g., see Bagnold, 1963). The latter possibility could be tested by making observations of sand wes over long time periods that include high-energy events. Observations to date have not done this.

Irrespective of sand-wave migration, erosion and consequent undermining of structural foundations or pipelines is possible in those areas. Peák tidal currents have been shown theoretically (Rappeport, 1981) and by direct observation (Bouma and others, 1979) to induce general motion of the sandy bed, even during less-than-maximum tidal range and calm weather conditions. Although the normal regime is transportational, with insignificant change in seafloor elevation, constriction of currents around obstacles can lead to local erosion (see Posey, 1971; Wilson and abel, 1973). Geopfert (1969) reported three instances of pipeline failure in upper cook Inlet when localized erosion led to vortex shedding, and resulting vibration caused the pipes to fail.

Localized erosion also can be expected in other areas of of lower cook Inlet. Areas of sea floor where water depth is less than about $50 \mathrm{~m}$ experience forces from storm waves that can erode sand, according to calculations made by Rappeport (1981). Even where the sedimentary environment has been classified as depositional (Hampton, 1982), which implies relatively quiet conditions of sediment accumulation, local erosion can occur. For example, the presence of scour marks around obstacles in the deep-water area of the mouth of the inlet attests that erosion around obstacles takes place even in relatively low-energy environments that are depositional on a large scale (Whit ney and others, 1979). Erosional sedimentary environments are common in northern lower Cook Inlet (Hampton, 1982), for example, where the sediment is gravel and sandy gravel (fig. 4) and sand ribbons occur (fig. 5). Currents are strong enough to winnow sand and probably some gravel-size grades, but erosion of sufficient magnitude to cause engineering problems is likely determined by local grain size. Large clasts might provide general bed immobility even under severe conditions.

Another aspect of high-energy sediment transport is abrasion of structural components. Visser (1969) reported considerable abrasion due to high silt concentrations in upper cook Inlet water, and similar effects from rapidly moving bed load might be encountered in the lower inlet.

The small mineral grains (typically clay) in the suspended load can absorb pollutants such as spilled oil. The fate of the pollutants absorbed thereby is determined by the fate of the suspended load. The sources of suspended material are from upper Cook Inlet and from the eastern Gulf of Alaska (Hein and others, 1978), and pollutants originating from either of these areas, or from within lower cook Inlet itself, can become an environmental concern.

Feely and others (1978) determined that suspended particles in lower cook Inlet can accommodate up to 118 their weight in cook Inlet crude oil and concluded that such pollutants could be distributed throughout the inlet before settling to the seafloor. Sediment that remains in suspension long enough would be swept into Shelikof strait, where the sedimentary regime is mainly depositional (Hampton, 1982), and long-term storage would result. 
Alternatively, some sediment might experience long-term storage in the quiet bays along the borders of the inlet. Across most of the lower cook Inlet sea floor, temporary incorporation into the sediment bed might take place. But, the periodic resuspension of fines that has been observed by Bouma and others (1979) and by Feely and Massoth (unpublished data) indicates eventual removal to more permanent storage sites. 


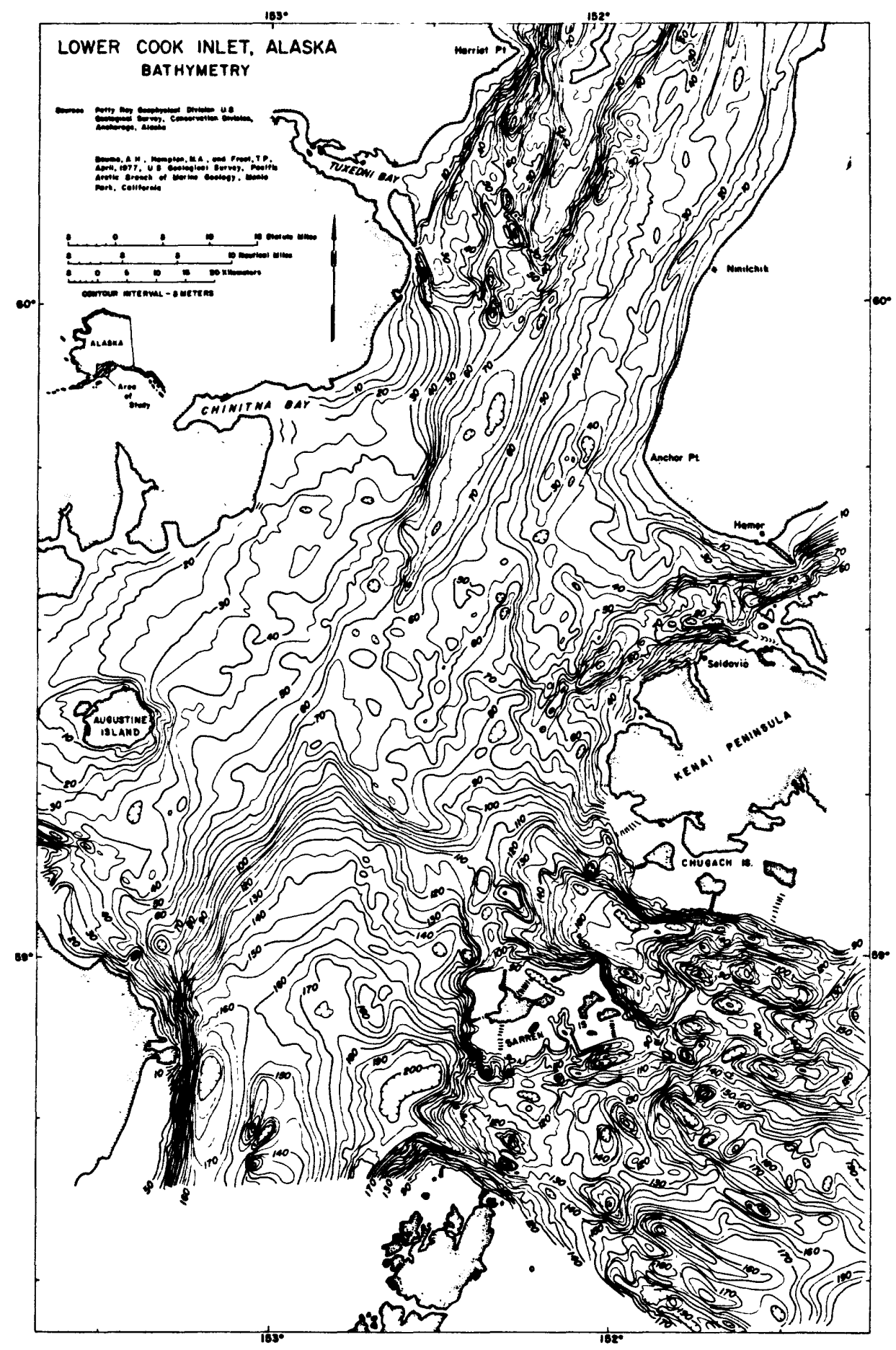

Figure 1. Bathymetry of lower Cook Inlet. (From Bouma and others, 1978.) 


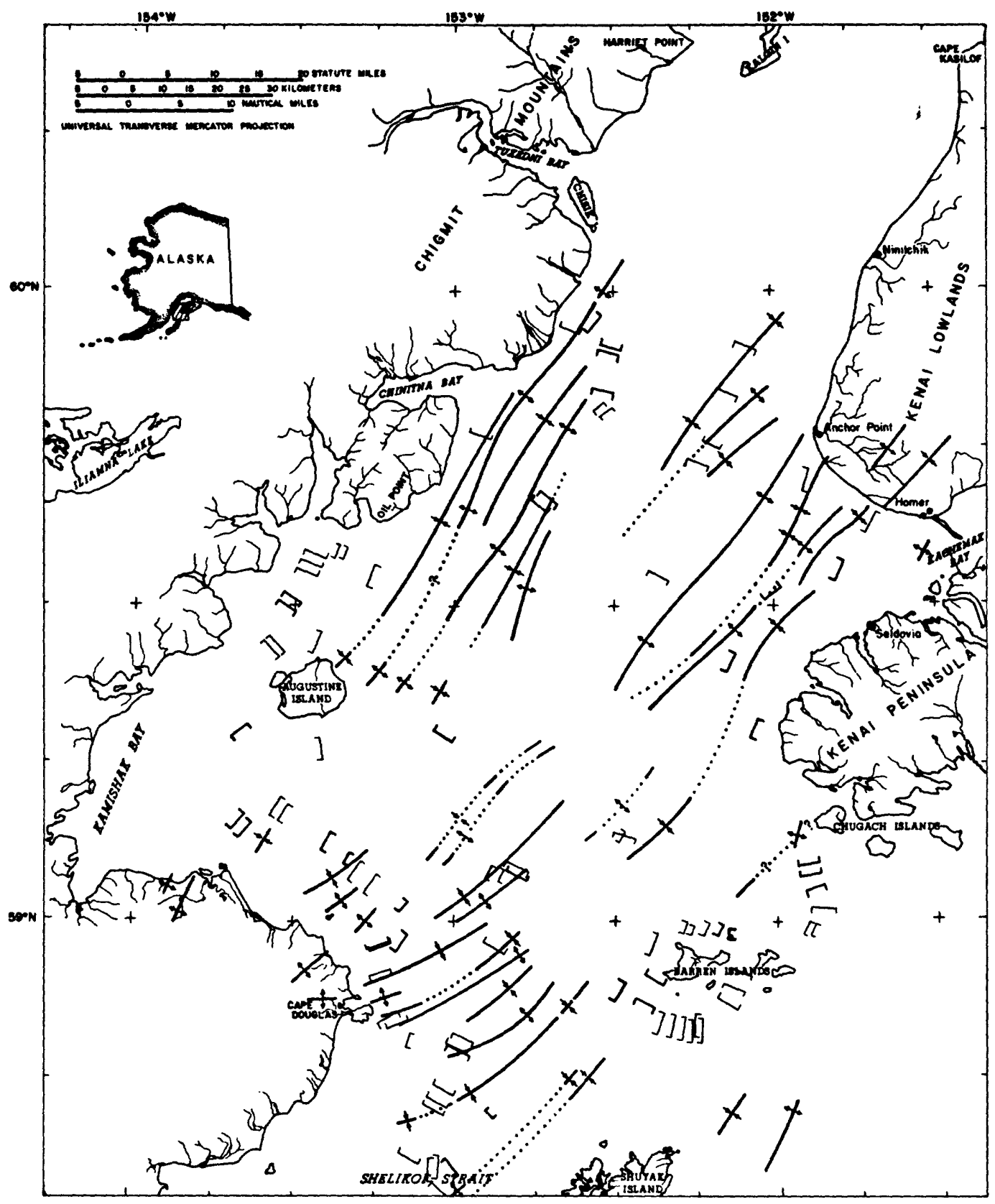

Figure 2. Shallow folds and faults in lower Cook Inlet. (From Hampton, 1982.) Note that the faults are mapped individually as they were identified on seismic-reflection profiles. The faults could not be correlated between adjacent tracklines. 


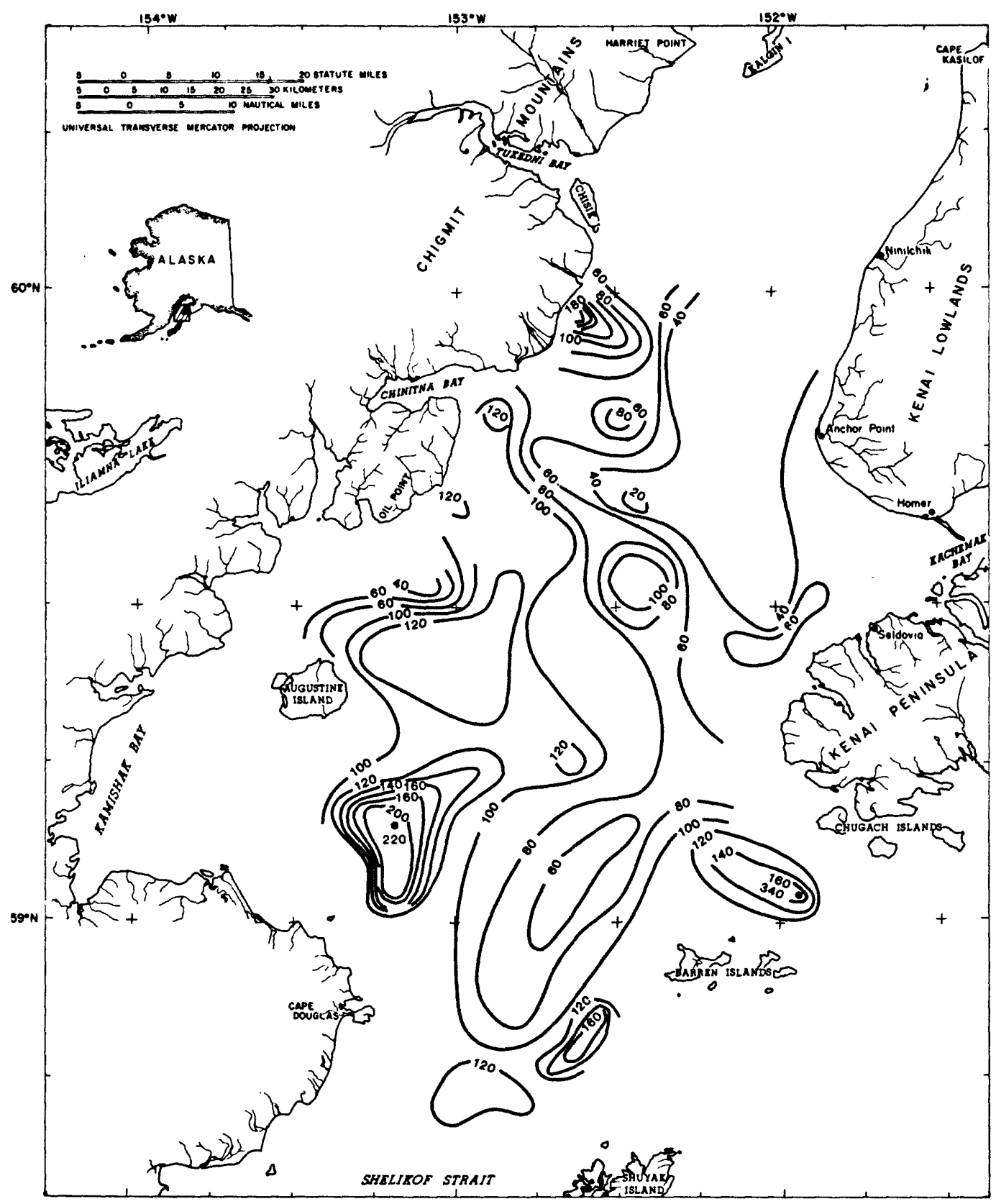

F. .

Figure 3. Thickness of unconsolidated sediment in lower Cook Inlet. Thickness in meters. 


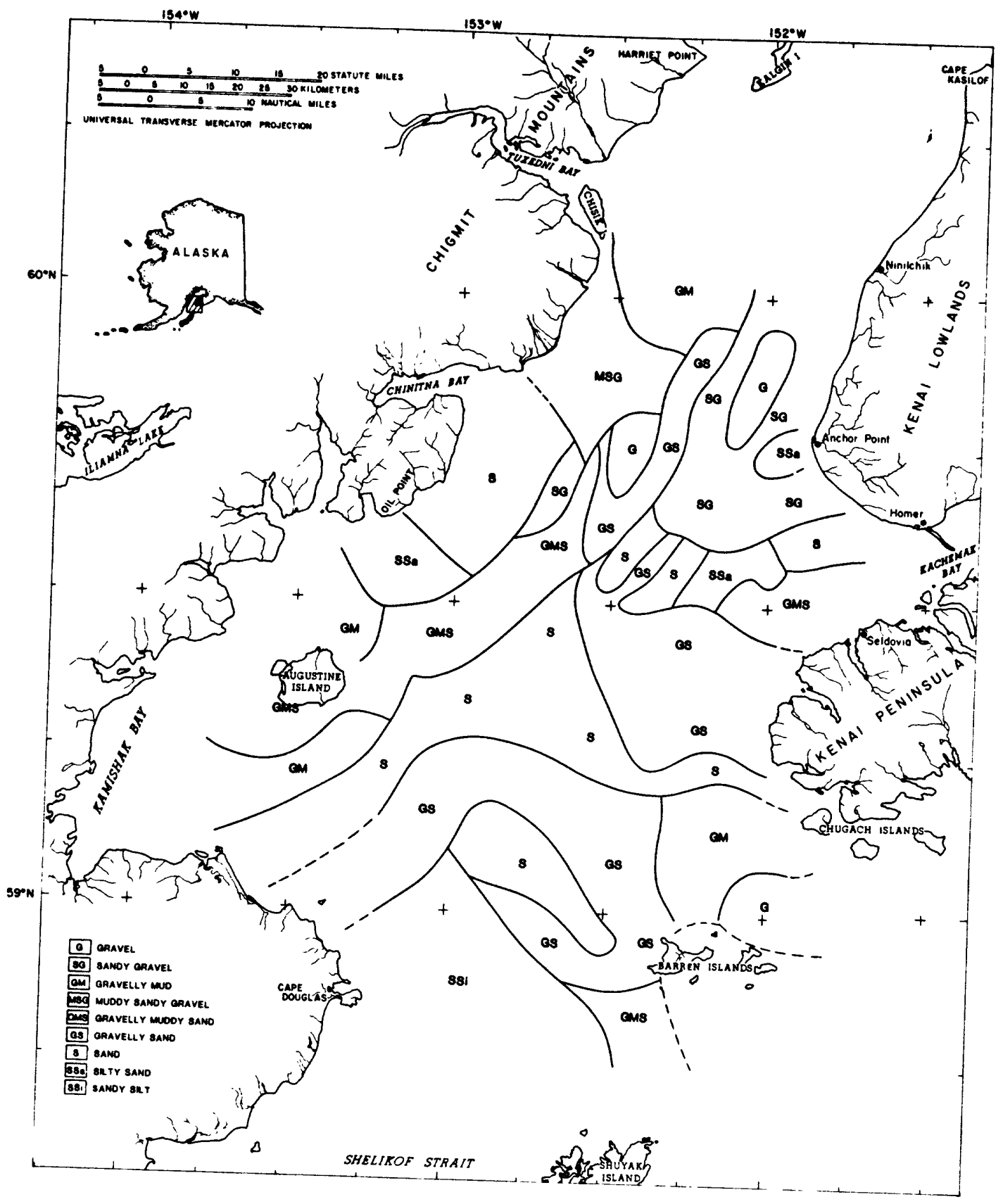

Figure 4a. Distribution of surficial sediment types in lower Cook Inlet. (From Hampton, 1982.) 

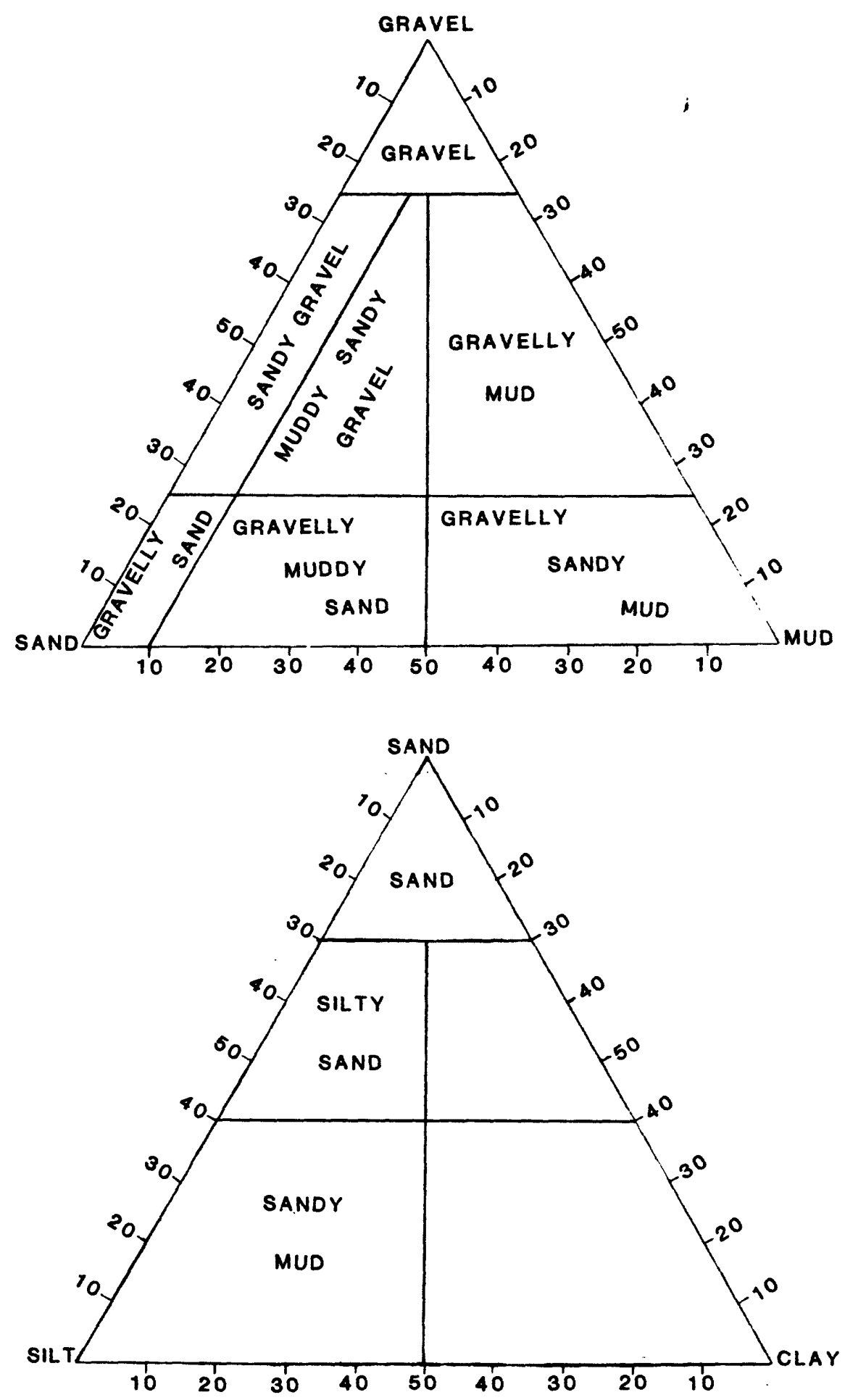

Figure 4b. Definition of sediment types used for mapping sea-floor sediment in lower Cook Inlet. 


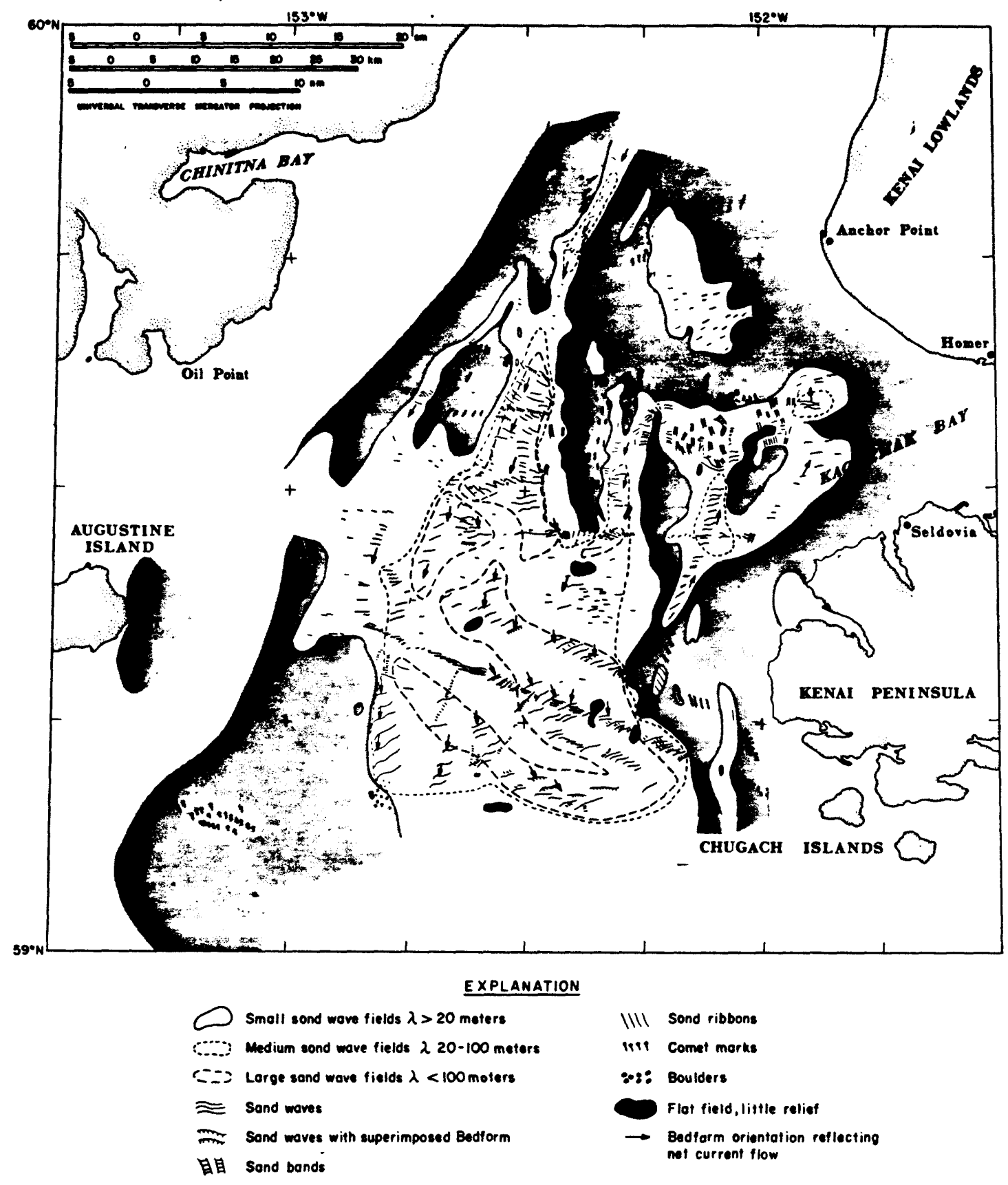

Figure 5. Distribution of bedforms on the sea floor of lower Cook Inlet. (From Orlando, 1982.) 
CHAPTER VII

SHELIKOF STRAIT ENVIRONMENTAL GEOLOGY

by

Monty A. Hampton

INTRODUCTION

Seismic-reflection records, collected with $40-$ to $95-\mathrm{cm}^{3}$ airgun, $800-$ joule minisparker, 800-joule boomer, and 3.5 and 12-kilohertz systems and covering over $6,400 \mathrm{~km}$ of trackline, and sediment samples collected at 42 stations have been examined to identify geologic conditions at or below the seafloor that might affect petroleum operations. A detailed synthesis of the environmental geology of Shelikof strait has recently been prepared by Hampton and others (1981).

The seafloor of Shelikof strait consists of a gently southwest-sloping central platform bordered by narrow marginal channels adjacent to the Kodiak islands and the Alaskan Peninsula ( $f i g .1$ ). Water depths in the northeast part are generally less than $200 \mathrm{~m}$ whereas those in the southwest generally exceed $200 \mathrm{~m}$ and can be as much as $300 \mathrm{~m}$. Superimposed on the platform are some local highs and lows with as much as $100 \mathrm{~m}$ relief. Along the axes of the marginal channels are several closed depressions of up to $100 \mathrm{~m}$ relief.

\section{SEISMICITY AND TECTONISM}

The tectonic setting of Shelikof Strait, near the convergent margin of two major lithospheric plates, makes it subject to large earthquakes. The Gulf of Alaska - Aleutian region is one of the most seismically active on earth and accounts for about 7 percent of the annual worldwide release of seismic energy; mostly in the form of large earthquakes (greater than magnitude 6). Since recording of large earthquakes began in 1902, at least 95 potentially destructive events $(M>6)$ have occurred in the vicinity of shelikof Strait. Recurrence intervals of major earthquakes ( $M>7.5$ ) within a given area along the Gulf of Alaska - Aleutian system have been estimated to be between a maximum of 800 years (Plafker and Rubin, 1967) and a minimum of 33 years (Sykes, 1971). The minimum recurrence interval of 33 years for a major earthquake that could affect the entire region might be exceeded by the lifetime of an oil-producing province, because the last major event was in 1964. So, although earthquakes cannot be predicted with confidence, seismic hazards are a valid safety concern for offshore development. Strong ground shaking, fault rupture, sediment displacement, and tectonic deformation have all been documented in nearby areas and can be expected to occur in

Shelikof strait. Examination of the distribution of historic epicenters shows no areal concentrations ( $H$. Pulpan, Univ. of Alaska, personal communication), such as exist nearby on Kodiak Shelf (Hampton and others, 1979), and therefore all areas within the strait must be considered equally prone to earthquakes and their effects.

The trends of shallow structures, those that affect the upper few hundred meters beneath the seafloor, are shown in fig. 2. Most major structures trend parallel to the axis of the strait, perpendicular to the direction of plate 
convergence. The faults in Shelikof strait that offset the seafloor imply recent activity and the probability of additional offset in the near future. The large seafloor offset $(100 \mathrm{~m})$ of some faults in the central part of the strait implies major movement in recent times. The short extent, irregular shape, and horst-like appearance of these faults suggest that they are caused by forces associated with localized uplift rather than being a direct result of regional compression.

\section{VOLCANISM}

At least 12 volcanoes classified as active (within historic time) or recently active $(<10,000 \mathrm{yr})$ are located along the Alaska Peninsula adjacent to the strait (Powers, 1958). The volcanoes are andesitic in composition and are subject to violent eruptions, as exemplified by the Katmai event of 1912, which expelled more than $25 \mathrm{~km}^{3}$ of ash (Wilcox, 1959). The most recent eruption was that of $\mathrm{Mt}$. Augustine in 1976 in nearby lower Cook Inlet. Eruptions from the volcanoes on the Alaska Peninsula could cause problems such as substantial ash accumulations and acid rains (see Evans and others, 1972). More destructive but local effects such as hot ash flows are not likely in most parts of the strait.

\section{SEDIMENTARY PROCESSES AND DEPOSITS}

Sediment in Shelikof Strait is of Pleistocene and Holocene age and was deposited by glacial, glaciomarine, and marine processes. It attains a thickness greater than $1000 \mathrm{~m}$ above a bedrock unconformity (fig. 3 ).

The sedimentary environment of Shelikof strait is characterized by deposition of sandy material in the northeast, progressively grading to silty clay size grades accumulating to the southwest (fig. 4). Problems associated with widespread scour or movement of large bedforms, a significant concern nearby on Kodiak Shelf and in lower Cook Inlet, should not exist in Shelikof strait. Local scour may occur around obstacles, as evidenced by comet marks at the northeast end of the strait.

Accumulation of fine sediment raises the possibility of pollutant storage on the seafloor. Pollutants introduced within the strait itself or in more diluted form from lower cook Inlet and the northeastern Gulf of Alaska could be stored long-term as deposits of contaminated fine particles.

Measurements of physical properties have been made on sediment cores from Shelikof Strait (Hampton and others, 1981). They are useful for categorizing the shallow sediment types in the strait, but deeper samples and more sophisticated testing would be necessary for engineering design purposes. few high values of sensitivity and compressibility have been measured on individual sediment samples, but most measurements of physical properties (vane shear strength, water content, plasticity) are in normal ranges for shallow marine sediment, and no unusual geotechnical problems are indicated. The deeper unconsolidated sediment beneath the seafloor apparently is composed of stable, coarse-grained glacial debris (Whitney and others, 1980).

Sediment slides are uncommon in the strait; only one relatively small occurrence is known (fig. 2). Nevertheless, the steep slopes along fault scarps must be regarded as possible sites of local instability. 
Indirect evidence for gas-charged sediment, in the form of anomalous acoustic returns in seismic-reflection profiles (fig. 5) is especially common in the northeast part of the strait, suggesting that weak and unstable sediment, as well as high gas pressures, might be present in the shallow subsurface. Measured gas contents in sediment cores are low, and no seeps from the seafloor have been found, which is not supportive of the hypothesis of widespread gas-charged sediment.

Craters occur over an area of approximately $1500 \mathrm{~km}^{2}$ on the sea floor in Shelikof strait (fig. 6). The craters appear on seismic-reflection profiles as small indentations, typically $50 \mathrm{~m}$ in diameter and less than $5 \mathrm{~m}$ deep. The craters might indicate the presence of gas-charged sediment, although the locations of craters do not correspond to the locations of acoustic anomalies. A more likely explanation for the craters is sediment venting due to liquefaction. Seismic profiles show no disruption of reflectors below about $10 \mathrm{~m}$ subbottom, and therefore the liquified layer probably exists above this depth. Thus, the venting may represent only a minor environmental concern. 


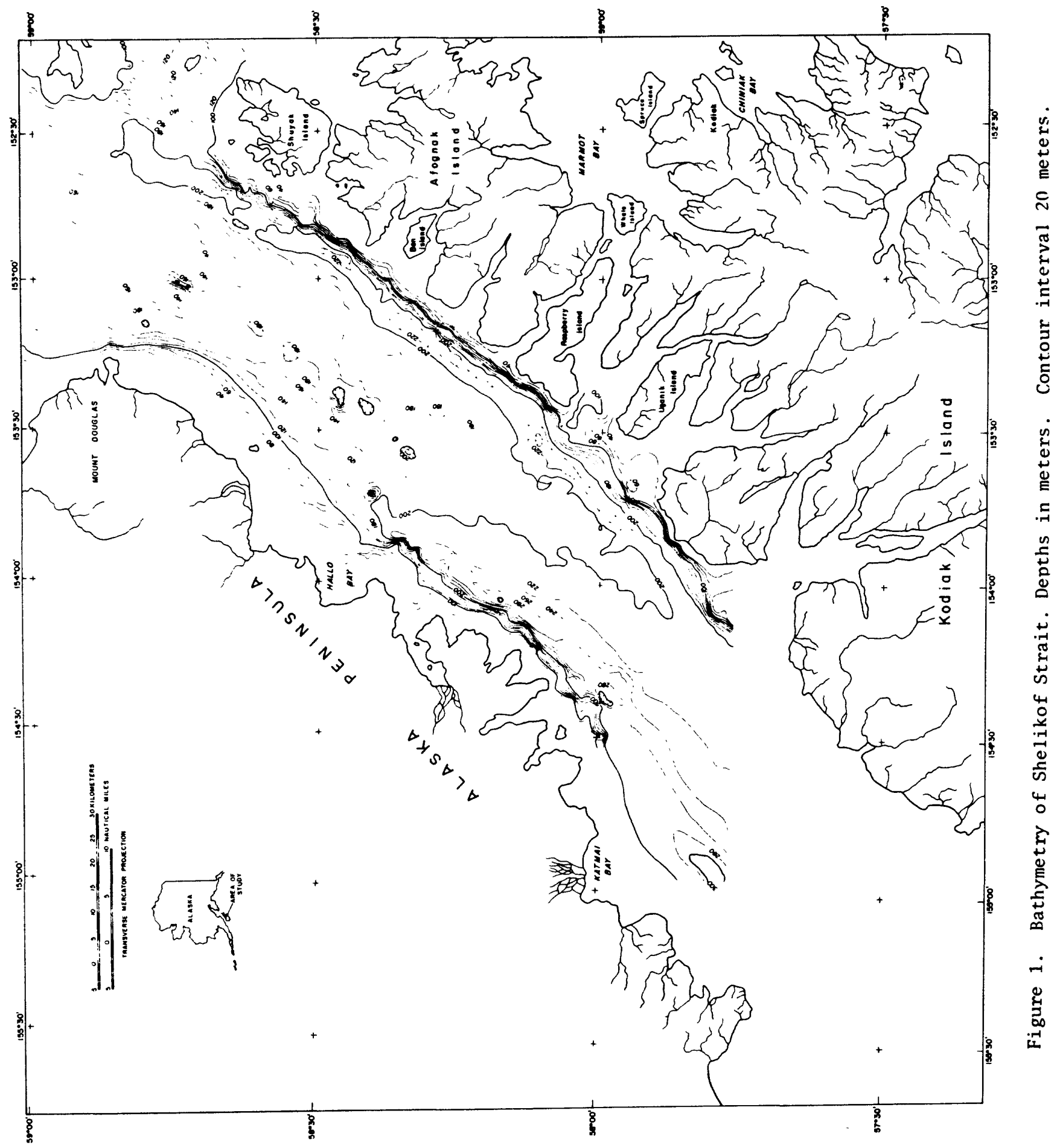




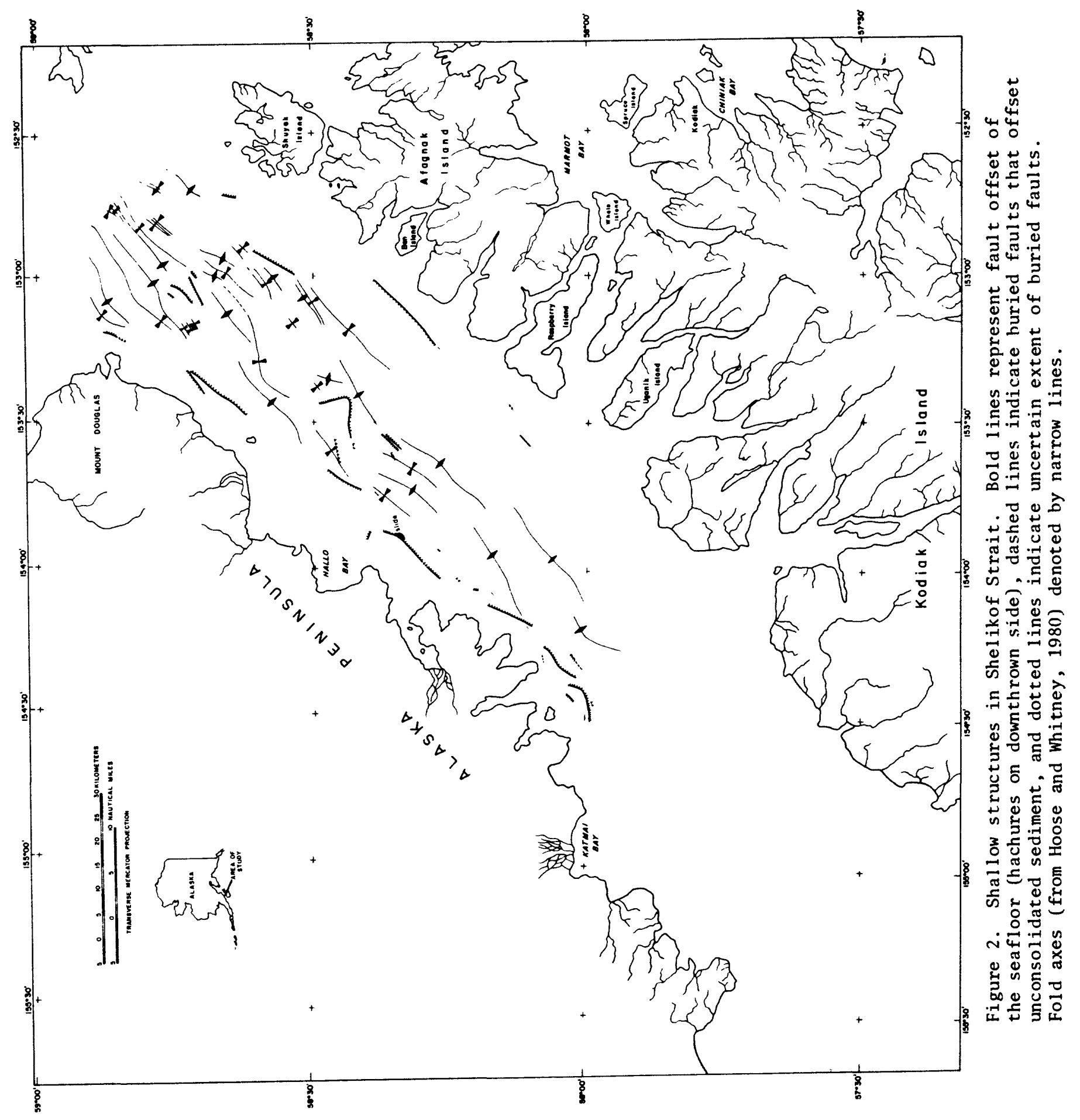




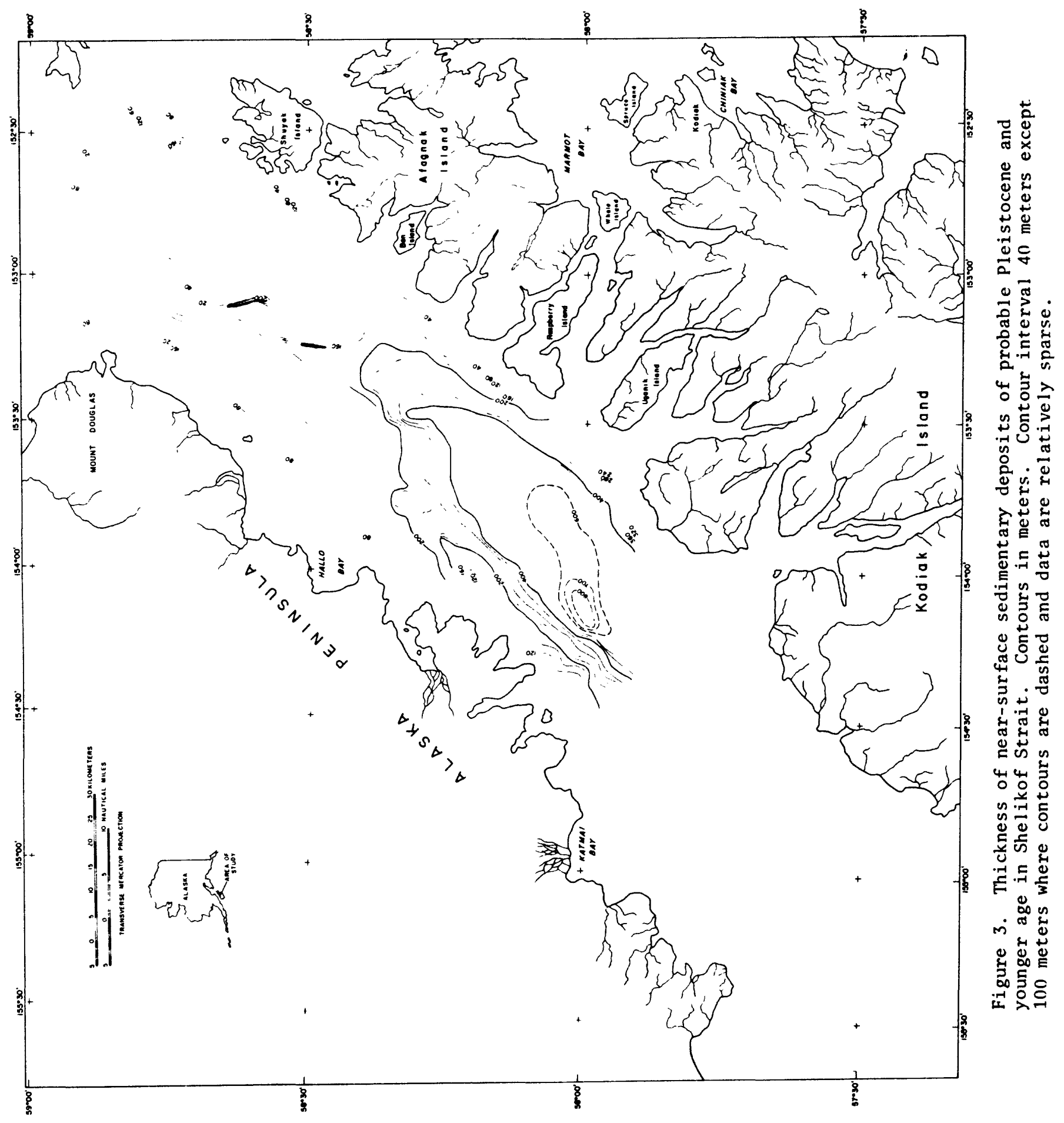




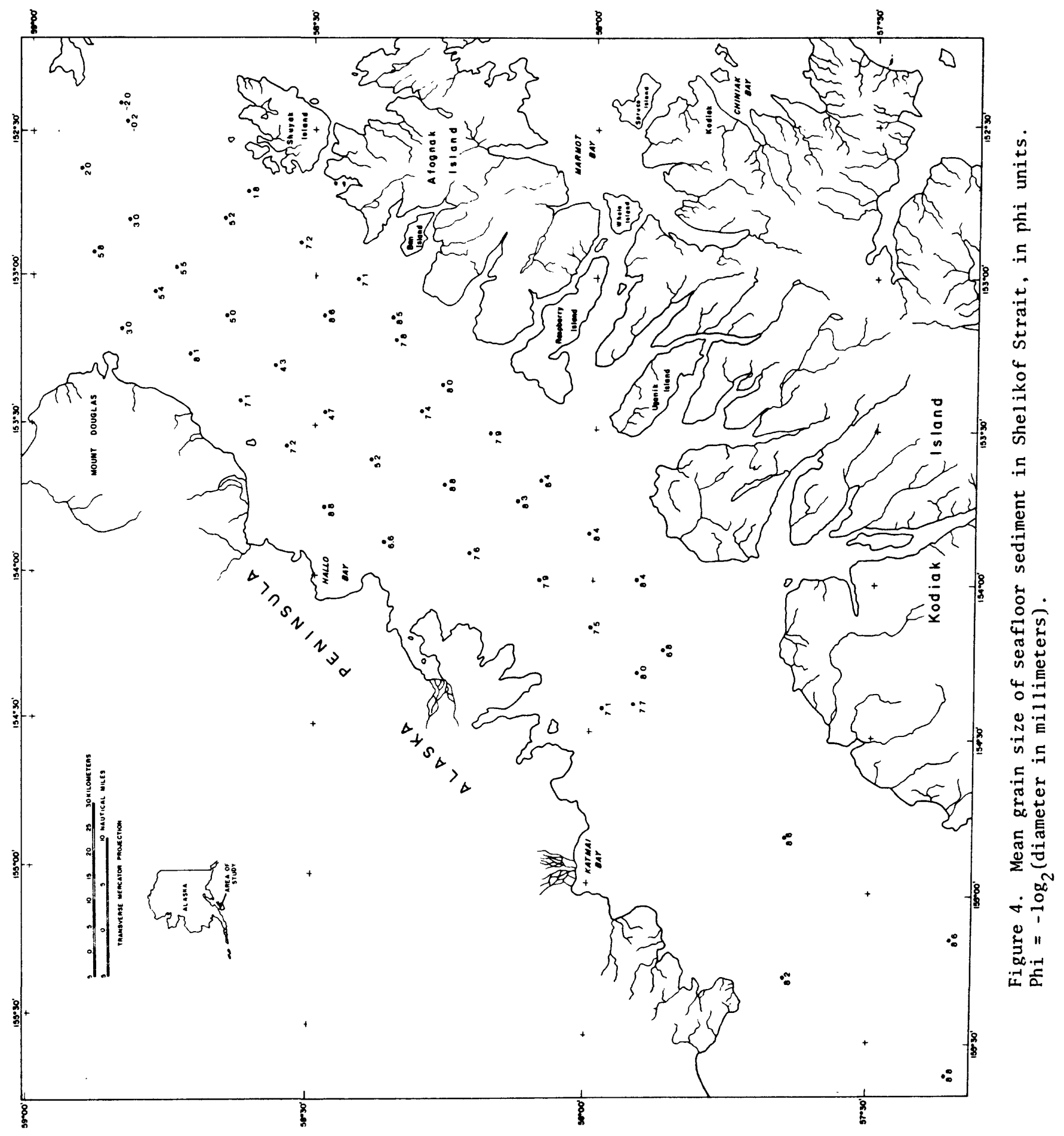




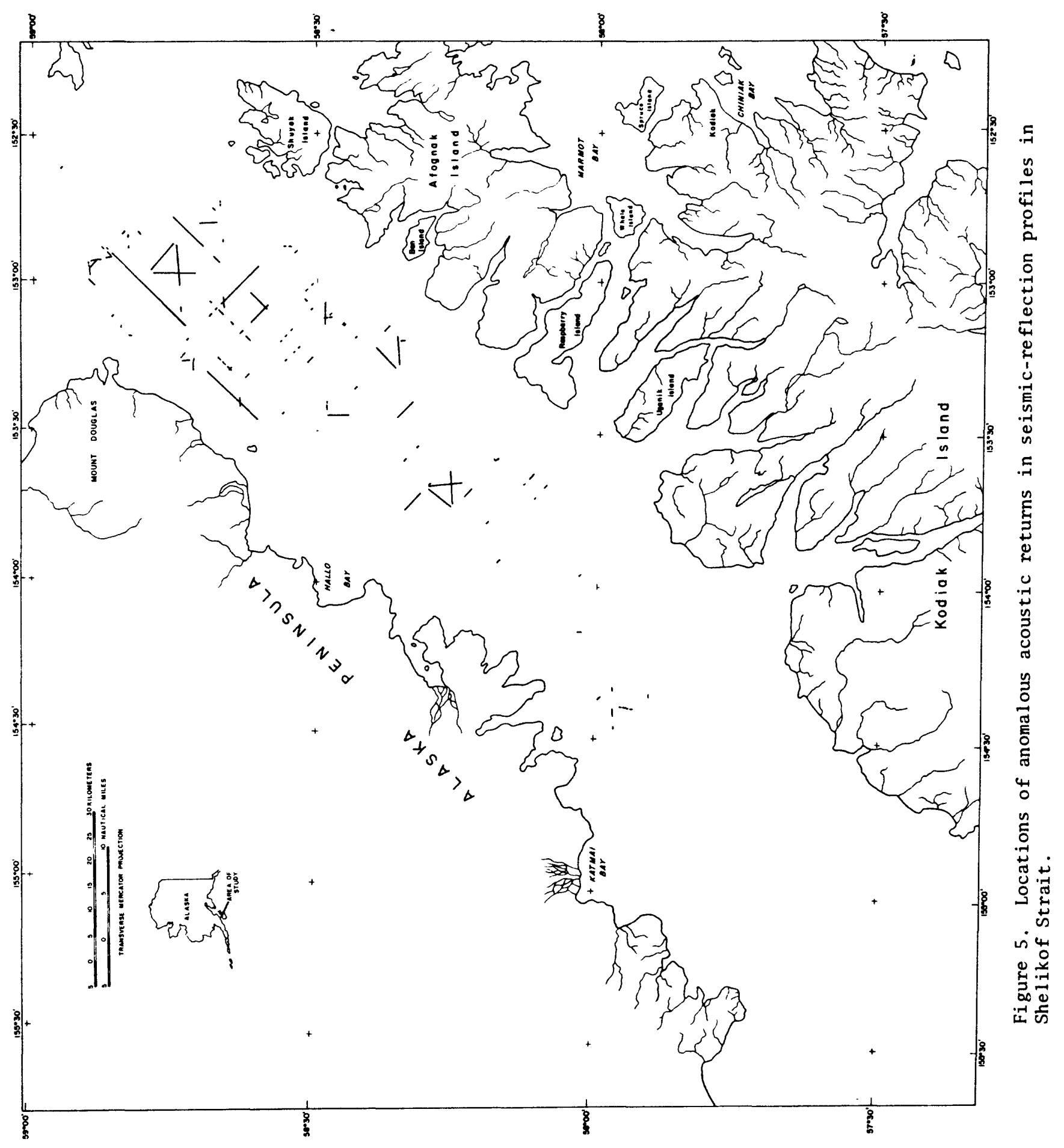




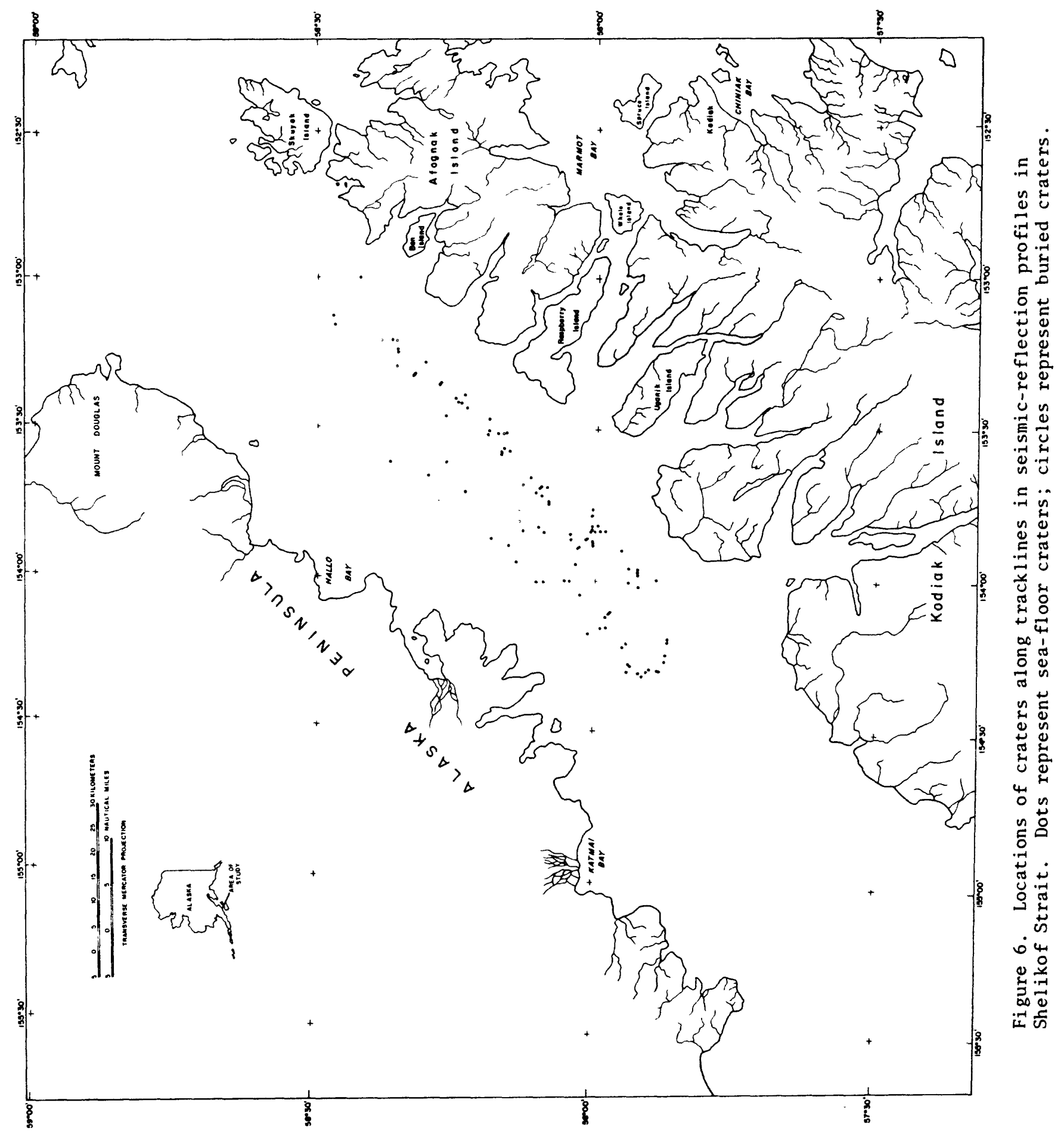


CHAPTER VIII

SEISM IC ACTIVITY IN THE NORTHERN GULF OF ALASKA SINCE 1974

by

Christopher D. Stephens and Robert A. Page

INTRODUCTION

The northern Gulf of Alaska is the most seismically active region in the United States apart from the Aleutian Islands (fig. 1). The earthquake history through 1973 has been reviewed by Plafker and others (1975; see figure 1). In a more recent review, McCann and others (1980) show that a great (magnitude $M$ equal to or greater than 7.8) 1900 earthquake previously located near Yakutat Bay more likely occurred near Kodiak Island.

Five great earthquakes have occurred in the province during the 1 ast 85 years. The most recent of these shocks, the 1964 Alaska earthquake (M 8.4 , M 9.2), is one of the largest earthquakes ever recorded in the world. since 1974 the largest earthquake to occur in the northern Gulf of Alaska is the 1979 st. Elias earthquake (M ${ }^{7.1)}$, a shallow, low-angle thrust event located beneath the Chugach-St. Elias mountains north of Icy Bay (Stephens and others, 1980; Hasega and others, 1980). This earthquake was felt over $500,000 \mathrm{~km}^{2}$ in southeastern Alaska, the United States, and western Canada (Stover and others, 1980). A maximum intensity (Modified Mercal1i) of VII was reported at a site about $70 \mathrm{~km}$ south of the epicenter. No surface faulting was reported for the St. Elias event, but its remote location in a mountainous region prohibited detailed field investigations. A significant aspect of this earthquake is that it ruptured the eastern end of a previously identified seismic gap for large earthquakes (fig. 1; McCann and others, 1980; Lahr and othes, 1980). All other earthquakes that occurred in the northern Gulf of Alaska since 1974 had magnitudes less than 6 .

Since september 1974 the USGS has been operating a network of sensitive seismographs with a station spacing of about $50 \mathrm{~km}$ along the northern Gulf of Alaska between Yakutat Bay and Prince william Sound. In the onshore regions within the network, earthquakes as small as magnitude 1 are routinely located, but the threshold for completeness is probably about magnitude 2. Offshore the level of completeness is higher - around 3 or 3.5 within about $100 \mathrm{~km}$ of the coast - and increases with distance from the network. Apart from the elevated level of seismicity in the St. Elias aftershock zone following that earthquake, the spatial distribution of seismicity defined by the earthquake epicenters is remarkably stable with time over the past several years (fig. 2). Concentrations of shallow (depth less than about $35 \mathrm{~km}$ ) epicenters occur onshore north of Icy Bay (the aftershock zone of the St. Elias earthquake), around Waxell Ridge between about $142^{\circ} 30^{\prime} \mathrm{W}$ and $143^{\circ} 30^{\prime} \mathrm{W}$ longitude, and near the mouth of the Copper River Delta. Offshore, most of the seismic activity is concentrated on the continental shelf west of the Pamplona Zone, although scattered events and occasional earthquake swarms are observed as far east as the longitude of Yakutat Bay. The largest earthquake that has been located offshore since 1974 is a magnitude $5.2 \mathrm{mb}$ event that occurred about $60 \mathrm{~km}$ southeast of Kayak Island. The aftershock zone of the St. Elias earthquake zone of the few areas where depths are sufficiently reliable to resolve 
dipping structures; the hypocenters define a diffuse zone that dips about $10^{\circ}$ northward and probably corresponds to the thrust interface between the Pacific and North American plates. The poor correlation of earthquake locations with mapped fault traces throughout the northern Gulf of Alaska (fig. 3) may be due in part to limits in the accuracy of the locations, but more likely results from the earthquakes occurring on lowangle buried faults. Despite the apparent stability in the pattern of the seismicity observed over the past eight years, it is important to note that significant earthquakes (for; example, the 1970 Pamplona Ridge sequence that included three events of magnitude class 6 ) have occurred recently in areas that now appear to be relatively quiet. In contrast, the aftershock zone of the St. Elias earthquake includes a region that had been noted prior to the earthquake as having one of the highest relative rates of activity along the coast between Yakutat Bay and eastern Prince William Sound.

\section{EARTHQUAKE RECURRENCE AND SEISMIC GAPS}

The northern Gulf of Alaska between the longitudes of eastern Prince William Sound and Icy Bay has been identified as a likely site for future large (M greater than or equal to 7.4) earthquakes based on independent evidence from geologic and seismic observations (for example, Plafker and others, 1975). Studies of Holocene marine terraces on Middleton Island (Plafker and Rubin, 1978) and between Icy Cape and Cape Yakataga (Plafker and others, 1981) indicate average uplift rates in these areas of about $1 \mathrm{~cm} / \mathrm{yr}$ over the past 4500-5000 yri individual episodes of uplift range between 4 and $46 \mathrm{~m}$ at intervals of 500 to $1400 \mathrm{yr}$. The evidence suggest that in both of these regions, tectonic uplift events of the type that form the terraces may be overdue. The historical seismic record shows that the portion of the Pacific-North American plate boundary between the rupture zones of the 1964 Prince William Sound earthquake and the 1979 St. Elias earthquake, the Yakataga seismic gap, has not ruptured in a large earthquake since at least 1899 (Lahr and others, 1980; McCann and others, 1980). Even if the 1899 earthquakes relieved all of the stress in the Yakataga gap, continued convergence across this boundary at a rate of about $5 \mathrm{~cm} / \mathrm{yr}$ since 1899 could result in a potential slip of about $4 \mathrm{~m}$. That amount of slip, if released in single gap-filling rupture, could generate an earthquake as large as $M 8$ (Lahr and others, 1980).

The region around southern Kodiak Island is the only part of the northern Gulf of Alaska where the historic seismic record is sufficiently complete to directly observe the repeat times of large earthquakes that rupture at least that portion of the plate boundary (Sykes and others, 1980). Since 1784 the average repeat time of such earthquakes has been about $80 \mathrm{yr}$.

Focal mechanisms that have been determined for teleseismically recorded earthquakes from the northern Gulf of Alaska were reviewed recently by Perez and Jacob (1980). The slip directions inferred for these events are generally consistent with north-northwest movement of the Pacific plate relative to the North American plate. Along the Queen Charlotte-Fairweather fault system the mechanisms are compatible with predominantly right-lateral strike-slip motion on northwest-southeast trending faults. Mechanisms for events in the region of the aftershock zone of the St. Elias earthquake, around Prince William Sound, and near Kodiak Island indicate lowangle thrusting on northward-tonorthwestward-dipping planes. Low-angle thrusting is also indicated for 
events that occurred offshore on the continental shelf between Montague Island and Kayak Island, near Pamplona Spur, and at the edge of the continental shelf west of Cross Sound. The slip directions for most of these events are rotated clockwise about $30^{\circ}-60^{\circ}$ from the directions expected based on relative plate motions; these mechanisms apparently reflect local complications in the deformation that is occurring in response to plate convergence. For the cross Sound events, the mechanisms have been interpreted to indicate either southwest-to-northeast convergence (Perez and Jacob, 1980) between the ,Pacific plate and the Yakutat block defined by Plafker and others (1978) or oblique thrusting of the Pacific plate beneath the continental shelf (Page, 1975). 


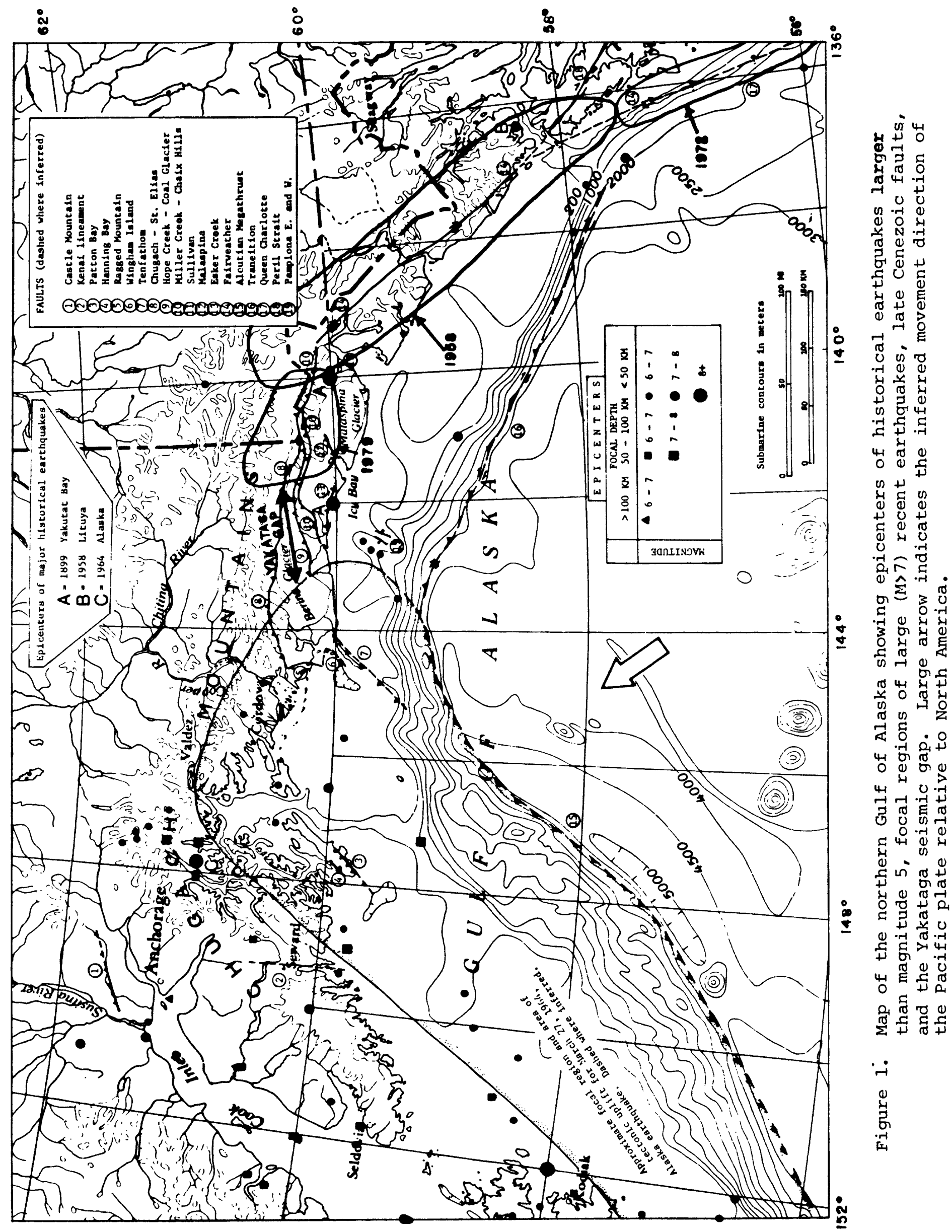




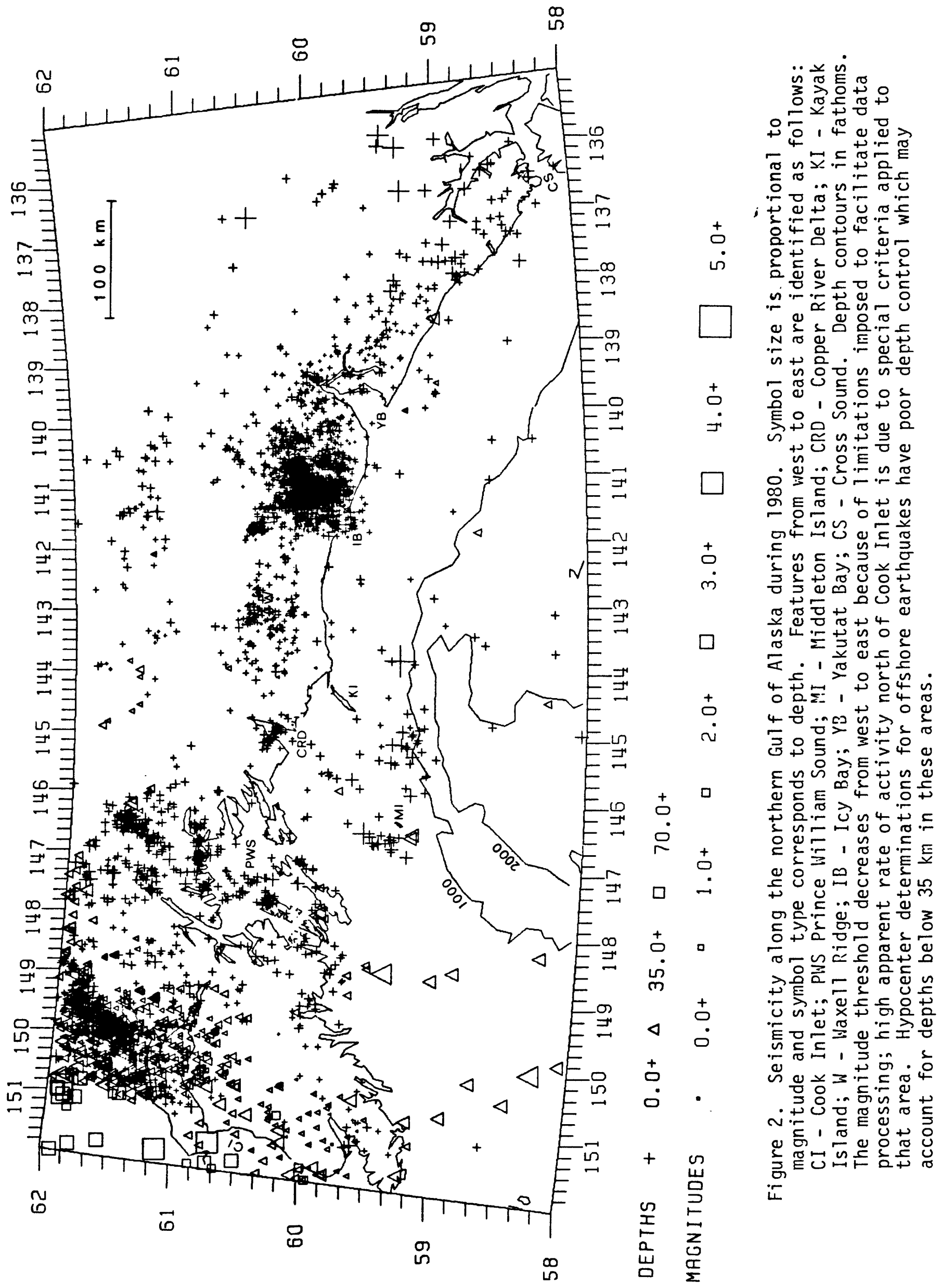




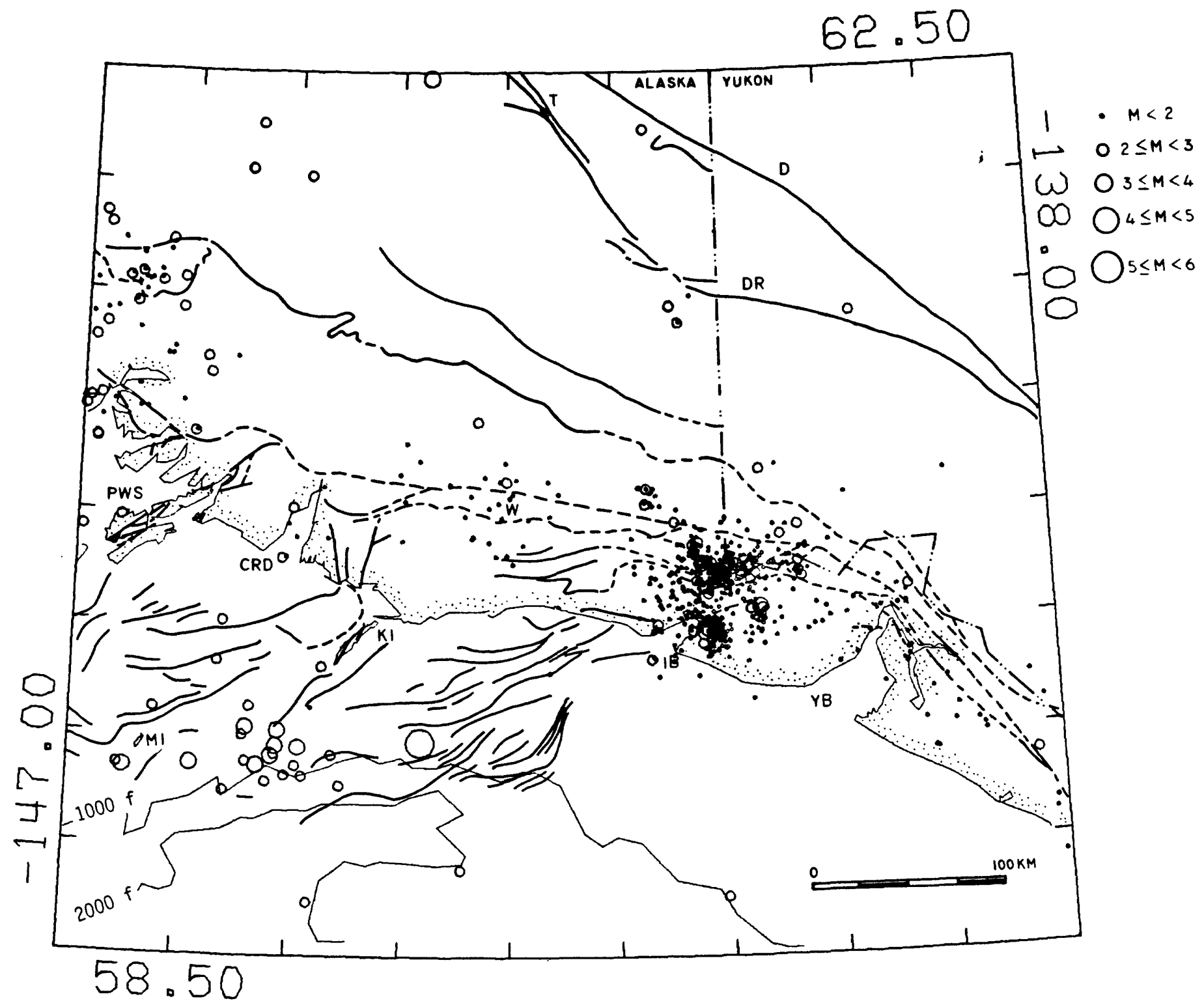

\section{JUL - 30 SEP 1980}

Figure 3a. Map showing the epicenters of 775 earthquakes that occurred during July-September, 1980, and their relation to mapped faults.

Symbol size is proportional to magnitude as indicated at upper right. Faults after Beikman (1980), Bruns (1979), and Clague (1979).

Abbreviations are as follows: CPD - Copper River nelta; D - Denali fault; DR - Duke River fault; IB - Icy Bay; KI - Kayak Island; MI Middleton Island; PWS - Prince William Sound; W - Waxell Ridge; YB Yakutat Bay. 


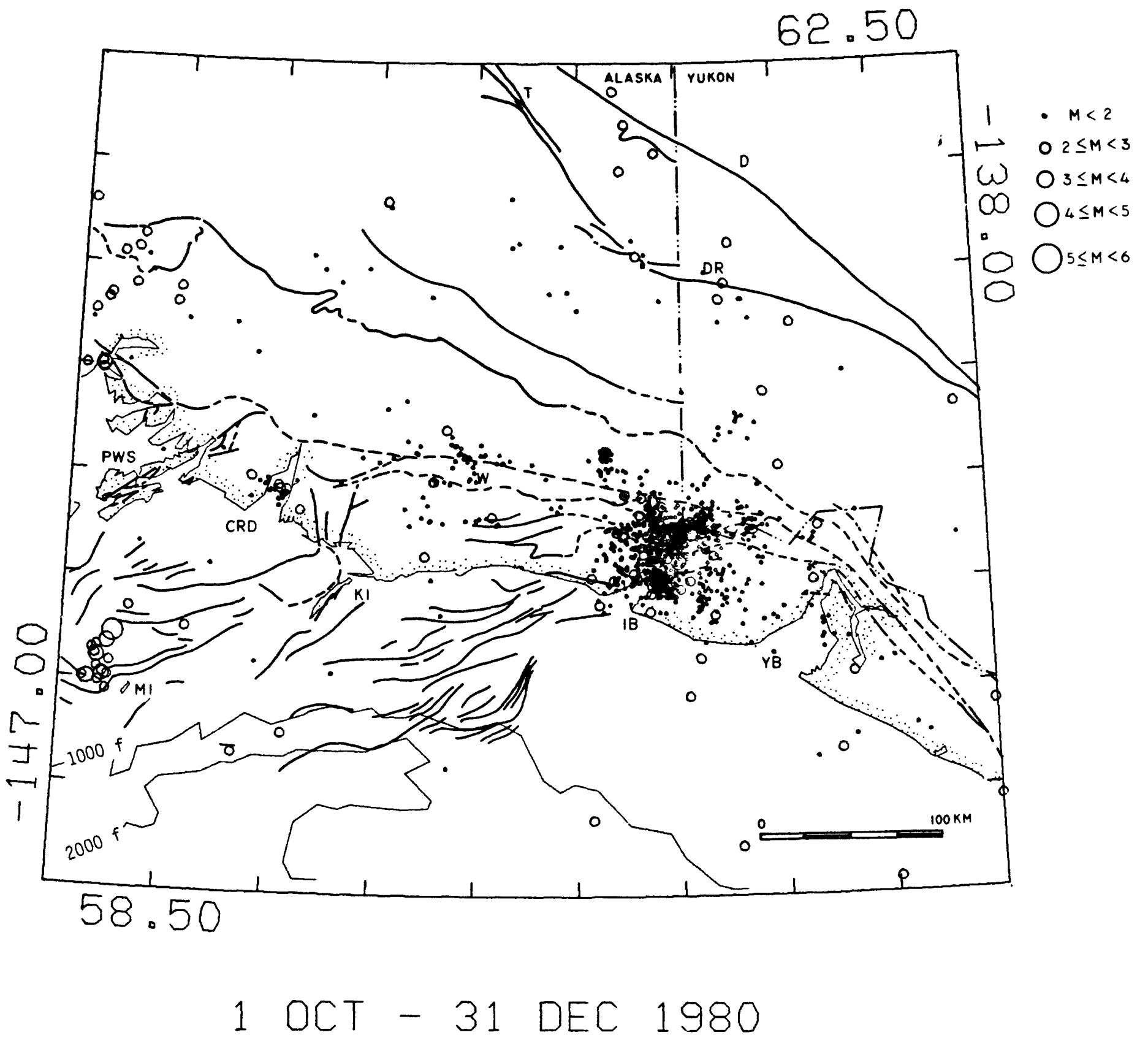

Figure 3b. Map showing epicenters of 1192 earthquakes that occurred during October-December, 1980. See Figure 3a for explanation of symbols. Note the variations in the distribution of seismicity, particularly offshore southwest of Kayak Island, as compared to the seismicity of the previous quarter shown in Figure 3a. 


\section{REFERENCES CITED}

Alaska Geological Society, 1970, Oil and gas fields in the Cook Inlet basin, Alaska: Anchorage, Alaska.

Anonymous, 1976, A stratigraphic study of the Gulf of Alaska Tertiary Province, northern Gulf of Alaska area: State of Alaska Open-File Report 93, 24 p.

Atwood, T. J., Bruns, T. R., Carlson, P. R., Molnia, B. F., and Plafker, George, 1981, Bathymetric maps of the northern Gulf of Alaska: U.S. Geological Survey Miscellaneous Field Studies Map MF-859, 3 sheets, scale $1: 250,000$.

Aud, B. W., 1979, Hydrocarbon potential in the Gulf of Alaska--what happened?: Oil and Gas Journal, v. 77, no. 5, p 218-225.

Bagnold, R. A., 1963, Beach and nearshore processes, in, Hill, M. N., ed., The Sea: v. 3, The Earth Beneath the Sea, New York, Interscience Publishers, p. 507-528.

Bayer, K. C., Mattick, R. E., Plafker, George, and Bruns, T. R., 1978, Refraction studies between Icy Bay and Kayak Island, eastern Gulf of Alaska: U.S. Geological Survey Journal of Research, v. 6, no. 5, p. 625636.

Beikman, H. M., 1980, Geologic Map of Alaska: U.S. Geological Survey, 1 sheet, scale $1: 2,500,000$.

Blasko, D. P., 1976a, Oil and gas exploration on the Iniskin Peninsula, Alaska: Bureau of Mines, Open-File Report 69-76, 19 p.

Blasko, D. P., 1976b, Oil and gas seeps in Alaska, Alaska Peninsula, western Gulf of Alaska: Bureau of Mines Report of Investigations $8122,78 \mathrm{p}$.

Blasko, D. P., Wenger, W. J., and Morris, J. C., 1972, Oil fields and crude oil characteristics, Cook Inlet basin, Alaska: U.S. Geological Survey Report of Investiqations $7688,25 \mathrm{p}$.

Bolm, J. G., Chmelik, F. B., Stewart, G. H., Turner, R. F., Waetjen, H. H., and Wills, J. C., 1976, Geological and operational summary, Alaska stratigraphic test OCS 75-60, No. 1, northern Gulf of Alaska: U.S. Geological Survey Open-File Report 76-635, 40 p.

Bonilla, M. G., and Buchanan, J. M., 1970, Interim report on worldwide historic surface faulting: U.S. Geological Survey Open-File Report.

Boss, R. F., Lennon, R. B., and Wilson, B. W., 1976, Middle ground shoal oil field, Alaska, in Braunstein, Jules, ed., North American oil and gas fields: American Association of Petroleum Geologists Memoir 24, p. 1-22. 
Bouma, A. H., Rappeport, M. I., Cachione, D. A., Drake, D. E., Garrison, I. E., Hampton, M. A., and Orlando, R. C., 1979, Bedform characteristics and sand waves, lower Cook Inlet, Alaska: in Proceedings of the 11th offshore Technology Conference, p. 1083-1094.

Bruns, T. R., 1979, Late Cenozoic structure of the continental margin,' northern Gulf of Alaska, in Sisson, Alexander, ed., The relationship of plate tectonics to Alaskan geology and resources: Alaska Geological Society 1977 Symposium Proceedings, p. I1-I30.

Bruns, T. R., 1982, Structure and petroleum potential of the continental margin between Cross Sound and ICy Bay, northern Gulf of Alaska: U.S. Geological Survey Open-File Report 82-929, 63 p.

Bruns, T. R., and Schwab, W. C., in press, Structure maps and seismic stratigraphy of the Yakataga segment of the continental margin, northern Gulf of Alaska: U.S. Geological Survey Miscellaneous Field Studies Map MF-1424, 2 sheets and 25 p., scale 1:250,000.

Bruns, T. R., and Bayer, K. C., 1977, Multichannel seismic reflection data acquired on the $M / V$ CECIL H. GREEN in the Gulf of Alaska, June-August, 1975: U.S. Geological Survey Open-File Report 77-325.

Burk, C. A., 1965, Geology of the Alaska Peninsula -- island arc and continental margin (Parts 1,2, and 3): Geological Society of America Memoir 99, 250 p.

Carlson, P. R., 1978, Holocene slump on continental margin off Malaspina Glacier, Gulf of Alaska: American Association of Petroleum Geologists, Bulletin, v. 62, no. 12, p. 2412-2426.

Carlson, P. R., 1979, Extensive sliding of continental slope sediments, eastern Gulf of Alaska: Geological Society of America, Abstracts with Programs, v. 11, p. 398 .

Carlson, P. R., Bruns, T. R., and Molnia, B. F., 1975, Submarine slides and near surface faults, northern Gulf of Alaska: U.S. Geological Survey Open-File Report 75-505, 1 map.

Carlson, P. R., Bruns, T. R., Molnia, B. F., and Schwab, w. C., 1982, Submarine valleys in the northeastern Gulf of Alaska: Characteristics and probable origin: Marine Geology, v. 47, p. 217-242.

Carlson, P. R., Levy, W. P., Molnia, B. F., and Hampson, J. C., Jr., 1978, Geotechnical properties of sediments from the continental shelf south of Icy Bay, northeastern Gulf of Alaska: U.S. Geological Survey Open-File Report 78-1071, 29 p.

Carlson, P. R., and Molnia, B. F., 1975, Preliminary isopach map of Holocene sediments, northern Gulf of Alaska: U.S. Geological Survey Open-File Report 75-507. 
Carlson, P. R., and Molnia, B. F., 1977, Submarine faults and slides on the continental shelf, northern Gulf of Alaska: Marine Geotechnology, v. 2, p. 275-290.

Carlson, P. R., Molnia, B. F., Kittelson, S. C. and Hampson, J. C., Jr., 1977, Distribution of bottom sediments on the continental shelf, northern Gulf of Alaska: U.S. Geological Survey Miscellaneous Field Studies Map MF-876, 2 sheets and 13 p., scale 1:500,000.

Carlson, P. R., Molnia, B. F., and Wheeler, M. C., 1980, Seafloor geologic hazards in OCS lease area 55, eastern Gulf of Alaska: Proceedings of the 12 th Offshore Technology Conference, Houston, v. 1, p. 563-603.

Carlson, P. R., and Molnia, B. F., 1977, Submarine faults and slides on the continental shelf, northern Gulf of Alaska: Marine Geotechnology, v. 2, p. 275-290.

Carlson, P. R., Plafker, George, Bruns, T. R., and Levy, W. P., 1979, Seaward extension of the Fairweather fault, in Johnson, K. M. and Williams, J. R., eds., The United States Geological Survey in Alaska: Accomplishments during 1978: U.S. Geological Survey Circular 804-B, p. B1 35-B139.

Clague, J. J., 1979, The Denali fault system in southwest Yukon Territory - a geological hazard?: in Current Research, Part A, Geological Survey of Canada, Paper 79-1, p. 169-178.

Chase, C. G., 1978, Plate kinematics: The Americas, East Africa, and the rest of the world: Earth and Planetary Science Letters, v. 37, p. 355-368.

Claypool, G. E., Threlkeld, C. N., and Magoon, C. B., 1980, Biogenic and thermogenic origins of natural gas in Cook Inlet basin, Alaska: American Association of Petroleum Geologists Bulletin, v. 64, p. 1131-1139.

Connelly, W., and Moore, J. C., 1979, Geologic map of the northwest side of the Kodiak Islands, Alaska: U.S. Geological Survey Map MF-1057, 2 sheets, scale 1:250,000.

Detterman, R. L., and Hartsock, J. K., 1966, Geology of the Iniskin-Tuxedni region, Alaska: U.S. Geological Survey Professional Paper 512, 78 p.

Detterman, R. L., Miller, T. P., Yount, M. E., and Wilson, F. H., 1981, Geologic map of the Chignik and Sutwik Island quadrangles, Alaska: U.S. Geological Survey Miscellaneous Investigations Map I-1229, 1 sheet, scale $1: 250,000$.

Detterman, R. L., and Reed, R. L., 1980, Stratigraphy, structure, and economic geology of the Iliamna quadrangle, Alaska: U.S. Geological Survey Bulletin, 1368-B, p. B1-B86, 1 sheet, scale 1:250,000. 
Detterman, R. L., Yount, M. E., and Case, J. E., 1981, Megafossil localities, checklists, and stratigraphic sections, Chignik and Sutwik Island quadrangles, Alaska: U.S. Geological Survey Miscellaneous Field Investigations Map MF-1053-N, 2 sheets.

Dolton, G. L., Carlson, K. H., Charpentier, R. R., Coury, A. B., Crovelli, R. A., Frezon, S. E., Khan, A. S., Lister, J. H., McMullin, R. H., Pike, R. L., Powers, R. B., Scott, E. W., and Varnes, K. L., 1981, Estimates of undiscovered recoverable conventional resources of oil and gas in the United States: U.S. Geological Survey Circular 860, 87 p.

Dow, W. G., 1977, Kerogen studies and geological interpretations: Journal of Geochemical Exploration, v. 2, p. 79-99.

Dow, W. G., 1979, Petroleum source beds on continental slopes and rises, in Geological and geophysical investigations of continental margins: American Association of Petroleum Geologists Memoir 29, p. 423-442.

Evans, C. D., Buck, E. H., Buffler, R. T., Fish, S. G., Forbes, R. B., and Parker, w. B., 1972, The Cook Inlet environment--background study of available knowledge: University of Alaska Resource Center, Alaska Sea Grant Program, Anchorage, Alaska, 137 p.

Feely, R. A., Cline, J. D., and Massoth, G. J., 1978, Transport mechanisms and hydrocarbon adsorption properites of suspended matter in lower Cook Inlet, ín Environmental Assessment of the Alaskan Continental Shelf: quarterly Report to Outer Continental Shelf Environment Assessment Program, National Oceanic and Atmospheric Administration, Boulder, Colorado, v. 2, p. 3-32.

Fisher, M. A., and Magoon, L. B., 1978, Geologic framework of lower Cook Inlet, Alaska: American Association of Petroleum Geologists Bulletin, v. 62, no. 3, p. 373-402, 18 figs., 1 table.

Fisher, M. A., and von Huene, R. E., 1980, Structure of upper Cenozoic strata beneath Kodiak Shelf, Alaska: American Association of Petroleum Geologists Bulletin, v. 64, no. 7, p. 1014-1033.

Foster, H. L., and Karlstrom, T. N. V., 1967, Ground breakage and associated effects in the Cook Inlet area, Alaska, resulting from the March 27, 1964, earthquake: U.S. Geological Survey Professional Paper 543-F, 28 p.

Geopfert, B. L., 1969, An engineering challenge-Cook Inlet, Alaska: Proceedings of the 1st offshore Technology Conference, p. I-512-I-522.

Geotechnical Engineers, Inc., (K. Dalenberg, D. P. Lagatta), 1978, Report on laboratory testing of shallow sediments, Gulf of Alaska: U.S. Geological Survey Contract No. 14-08-0001-17353.

Hampton, M. A., 1982, Synthesis report: environmental geology of lower Cook Inlet, Alaska: U.S. Geological Survey Open-File Report 82-197, 55 p. 
Hampton, M. A., Bouma, A. H., Carlson, P. R., Molnia, B. F., Clukely, E. C., and Sangrey, D. A., 1978, Quantitative study of slope instability in the Gulf of Alaska: Proceedings of the 10th offshore Technology Conference, Houston, Texas, 4, p. 2307-2318.

Hampton, M. A., Bouma, A. H., Pulpan, H., and von thuene, R., 1979, ; Geoenvironmental assessment of the Kodiak Shelf, western Gulf of Alaska: Proceedings of the 11th offshore Technology Conference, p. 365376.

Hampton, M. A., Johnson, K. H., Torresan, M. E., and Winters, W. J., 1981, Description of seafloor sediment and preliminary geo-environmental report, Shelikof Strait, Alaska: U.S. Geological Survey Open-File Report 81-1133, 86 p.

Harding, T. P., and Lowell, J. D., 1979, Structural styles, their plate tectonic habitats, and hydrocarbon traps in petroleum provinces: American Association of Petroleum Geologists Bulletin, v. 63, no. 7, p. 1016-1058.

Hasegawa, H. S., Lahr, J. C., and Stephens, C. D., 1980, Fault parameters of the St. Elias, Alaska, earthquake of February 28, 1979: Bulletin of the Seismological Society of America, v. 70, n. 5, p. 1651-1660.

Hein, J. R., Bouma, A. H., Hampton, M. A., and Ross, C. R., 1979, Clay mineralogy, fine-grained sediment dispersal, and inferred current patterns, lower Cook Inlet and Kodiak Shelf, Alaska: Sedimentary Geology, v. 24, p. 291-306.

Imlay, R. W., and Detterman, R. L., 1977, Some lower and middle Jurassic beds in Puale Bay-Alinchak Bay area, Alaska Peninsula (geologic notes): American Association of Petroleum Geologists Bulletin, v. 61, no. 4, p. 607-611.

Jones, D. C., Silberling, N. J., and Hillhouse, J., 1977, Wrangellia -- a displaced terrane in northwestern North America: Canadian Journal of Earth Sciences, v. 14, p. 2565-2577.

Jones, D. C., Silberling, N. J., Berg, H. C., and Plafker, George, 1981, Map showing tectonostratigraphic terranes of Alaska, columnar sections, and summary description of terranes: U.S. Geological Survey Open-File Report 81-792, 20 p., 2 sheets.

Keller, A. and Reiser, H. N., 1959, Geology of the Mount Katmai area, Alaska: U.S. Geological Survey Bulletin 1058-G, p. 261-298.

Relly, T. E., 1963, Geology and hydrocarbons in Cook Inlet basin, Alaska, in Backbone of the Americas: American Association of Petroleum Geologists Memoir 2, p. 278-296. 
Kelly, T. E., 1968, Gas accumulations in nonmarine strata, Cook Inlet basin, Alaska, in' Beebe, W. B., and Curtis, B. F., eds., Natural gases of North America: American Association of Petroleum Geologists Memoir 9, v. 1, p. 49-64.

Kirschner, C. E., and Lyon, C. A., 1973, Stratigraphic and tectonic development of Cook Inlet Petroleum province, in Pitcher, M. G., ed., Arctic Geology: American Association of Petroleum Geologists Meimoir 19, p. 396-407.

Lahr, J. C., and Page, R. A., 1976, Earthquake activity and ground shaking in and along the eastern Gulf of Alaska, in Environmental assessments of the Alaskan continental shelf: v. 13, Geology, Boulder, Colorado, Environmental Research Lab., p. 69-90.

Lahr, J. C. and Plafker, George, 1980, Holocene Pacific-North American plate interaction in southern Alaska: Implications for the Yakataga seismic gap: Geology, v. 8, p. 483-486.

Lahr, J. C., Stephens, C. D., Hasegawa, H. S., Boatwright, John, and Plafker, George, 1980, Alaska seismic gap only partially filled by February 28, 1979 earthquake: Science, v. 207, p. 1351-1353.

Lahr, J. C., Stephens, C. D., and Rogers, J., 1980, Earthquake activity and ground shaking in and along the eastern Gulf of Alaska, in Environmental assessment of the Alaskan Continental Shelf: Environmental Research Laboratory, Boulder, Colorado, Quarterly Reports 9/79 - 12/79.

Law Engineering Testing Co. (R. G. Hamadock, P. G. Swanson, P. W. Mayne), 1981, Report of laboratory testing core samples from the continental shelf, Yakutat and Kodiak, Alaska: U.S. Geological Survey Contact no. 1408-0001-19241.

Law Engineering Testing Co. (R. W. Sparrow, P. G., Swanson, R. E., Brown), 1978, Report of laboratory testing of Gulf of Alaska cores: U.S. Geological Survey Contract no. 14-08-0001-17356.

Lee, H. J., Edwards, B. D., and Field, M. E., 1981, Geotechnical analysis of a submarine slump, Eureka, California: Proceedings of the 1981 offshore Technology Conference, Vol. 1, p. 53-65.

Loney, R. A., Brew, D. A., Muffler, L. J. P., and Pomeroy, J. S., 1975, Reconnaissance geology of Chichagof, Baranof, and Kruzof Islands, southeastern Alaska: U.S. Geological Survey Professional Paper 792, 105 p.

Magoon, L. B., Adkison, W. L., Chmelik, F. B., Dolton, G. L., Fisher, M. A., Hampton, M. A., Sable, E. G., and Smith, R. A., 1976, Hydrocarbon potential, geologic hazards, and infrastructure for exploration and development of the lower Cook Inlet, Alaska: U.S. Geological Survey Open-File Report 76-449, 124 p. 
Magoon, L. B., Adkison, W. L., and Egbert, R. M., 1976, Map showing geology, wildcat wells, Tertiary plant-fossil localities, $\mathrm{K}-\mathrm{Ar}$ age dates and petroleum operations, Cook Inlet area, Alaska: U.S. Geological Survey Miscellaneous Investigations Map I-1019, 3 sheets, scale 1:250,000.

Magoon, L. B., Bouma, A. H., Fisher, M. A., Hampton, M. A., Scott, E. W., and Wilson, C. L., 1979, Resource report for proposed OCS sale no. 60, lower Cook Inlet-Shelikof Strait, Alaska: U.S. Geological Survey Open-File Report 79-600, 38 p.

Magoon, L. B., and Claypool, G. E., 1981, Petroleum geology of Cook Inlet Basin -- an exploration model: American Association of Petroleum Geologists Bulletin, v. 65, p. 1043-1061.

Magoon, L. B., and Claypool, G. E., 1979, Origin of Cook Inlet oil, in Sisson, Alexander, ed., The relationship of plate tectonics to Alaskan geology and resources: Alaska Geological Society 1977 Symposium Proceedings, p.G1-G12.

Magoon, L. B., Hampton, M. A., Sable, E. G., Smith, R. A., and Chemlik, F. B., 1975. Hydrocarbon potential, geologic hazards, and the technology, timeframe and infrastructure for exploration and development of the lower Cook Inlet, Alaska--A preliminary assessment: U.S. Geological Survey Open-File Report 75-549, 74 p.

Malloy, R. J., and Merrill, G. F., 1972, Vertical crustal movements on the seafloor, in The Great Alaska Earthquake of 1964, Oceanography and Coastal Engineering: Washington, D. C., National Research Council, National Academy of Sciences, p. 252-265.

McCann, w., Perez, O., and Sykes, L., 1980, Yakataga seismic gap, southern Alaska: seismic history and earthquake potential: Science, v. 207, p. 1309-1314.

Minster, J. B., and Jordan, T. H., 1978, Present day plate motions: Journal of Geophysical Research, v. 83, no. B11, p. 5331-5354.

Molnia, B. F., 1979, Origin of gas pockmarks and craters: Geological Society of America, Abstracts with Programs, v. 11, p. 481-482.

Molnia, B. F., and Carlson, P. R., 1975, Surface sediment distribution, northern Gulf of Alaska: U.S. Geological Survey Open-File Report 75-505, 1 sheet.

Molnia, B. F., and Carlson, P. R., 1978, Surface sedimentary units of northern Gulf of Alaska continental shelf: American Association of Petroleum Geologists Bulletin, v. 62, no. 4, p. 633-643.

Molnia, B. F., and Carlson, P. R., 1980, Quaternary sedimentary facies on the continental shelf of the northeastern Gulf of Alaska, in Field, M. E., Bouma, A. and Colburn, I., ed., Quarternary depositional environments of the U.S. Pacific continental margin: Society Economic Palentologists and Mineralogists Symposium, Pacific Section, Bakersfield p. 157-168. 
Molnia, B. F., Carlson, P. R., and Bruns, T. R., 1977, Large submarine slide in Kayak Trough, Gulf of Alaska, in' Coates, D. R., ed., Landslides: Reviews in Engineering Geology, vi 3, Geological Society of America, p. 137-148.

Molnia, B. F., Carlson, P. R., Kvenvolden, K. A., 1978, Gas-charged sediment areas in the northern Gulf of Alaska: Geological Society of America, Abstracts with Programs, v. 10, no. 7, p. 548-549.

Molnia, B. F., Levy, W. P., and Carlson, P. R., 1980, Map showing Holocene sedimentation rates in the northeastern Gulf of Alaska: U.S. Geological Survey Miscellaneous Field Studies Map, MF-1170, 1 sheet.

Molnia, B. F., and Rappeport, M. L., 1982, Seafloor mosaic of the Alsek sediment unstability area: U.S. Geological Survey Miscellaneous Field Studies Map, 2 sheets (in press).

Molnia, B. F., and Sangrey, D. A., 1979, Glacially derived sediments in the Guff of Alaska; geology and engineerings characteristics: Proceedings of the 1979 Offshore Technology Conference, Houston, v. 1, p. 647-655.

Moore, G. W., 1967, Preliminary geologic map of Kodiak Island and vicinity, Alaska: U.S. Geological Survey Open-File Map, scale 1:250,000.

Moore, J. C., 1974, Geologic and structural map of the Shumagin Islands, southwestern Alaska: U.S. Geological Survey Miscellaneous Investigations Map I-815, scale 1:250,000.

Naugler, F. P. and Wageman, J. M., 1973, Gulf of Alaska: magnetic anomalies, fracture zones, and plate interactions: Geological Society of America Bulletin, v. 84, no. 5, p. 1575-1584.

Orlando, R. C., 1982, Morphologic and sediment characteristics of bedforms in lower Cook Inlet, Alaska: Master of Science Thesis, San Jose State University, San Jose, California, in preparation.

Page, R. A., 1973, The Sitka, Alaska, earthquake of 1972: Earthquake Information Bulletin, v. 5, p. 4-9.

Page, R. A., 1975, Evaluation of seismicity and earthquake shaking at offshore sites: i'n offshore Technology Conference, 7th, Houston, Texas: Proceedings v. 3, p. 179-190.

Perez, O. J., and Jacob, K. H., 1980, Tectonic model and seismic potential of the eastern Gulf of Alaska and Yakataga seismic gap: Journal of Geophysical Research, v. 85, n. B12, p. 7132-7150.

Plafker, George, 1967, Geologic map of the Gulf of Alaska Tertiary province, Alaska: U.S. Geological Survey Miscellaneous Geologic Investigations Map I-484, scale $1: 500,000$.

Plafker, George, 1971, Possible future petroleum resources of Pacific-margin Tertiary basin, Alaska, in' Future petroleum provinces of North America: American Association of Petroleum Geologists Memoir 15, p. 120-135. 
Plafker, George, 1972, Tectonics. In: The Great Alaska Earthquake of 1964, Geology: Washington, D.C., National Research Council, National Academy of Sciences, p. 47-122.

Plafker, George, and Addicott, w. O., 1976, Glaciomarine deposits of Miocene through Holocene age in the Yakataga Formation along the Gulf of Alaska margin, 'ín Miller, T. P., ed., Recent and ancient sedimentary erivironments in Alaska: Alaska Geological Society Symposium Proceedings, p. Q1Q23.

Plafker, George, Bruns, T. R., Carlson, P. R., Molnia, B. F., Scott, E. W., Kahler, Roger, and Wilson, Charles, 1978a, Petroleum potential, geologic hazards, and technology for exploration in the outer continental shelf of the Gulf of Alaska Tertiary province: U.S. Geological Survey Open-File Report 78-490, 33 p.

Plafker, George, Bruns, T. R. and Page, R. A., 1975, Interim report on the petroleum resource potential and geologic hazards in the outer continental shelf of the Gulf of Alaska Tertiary province: U.S. Geological Survey Open-File Report 75-592, 74 p.

Plafker, George, Bruns, T. R., Winkler, G. R., and Tysdal, R. G., 1982, Cross Section of the eastern Aleutian Arc, from Mount Spurr to the Aleutian Trench near Middleton Island, Alaska: Geological Society of America, Cross Section, 1 sheet, 1:250,000, in press.

Plafker, George, Carlson, P. R., Coonrad, w. L., Hunt, S. J., and quinterno, Paula, 1979, Geologic implications of 1978 outcrop sample data from the continental slope: U.S. Geological Survey Circular 804-B, p. 143-146.

Plafker, George, and Claypool, George, 1979, Petroleum source potential of rocks dredged from the continental slope in the eastern Gulf of Alaska: U.S. Geological Survey Open-File Report 79-295, 24 p.

Plafker, George, Hudson, Travis, Bruns T.R., and Rubin, Meyer, 1978b, Late Quaternary offset along the Fairweather fault and crustal plate interactions in southern Alaska: Canadian Journal of Earth Sciences, v. 15 , no. 5 , p. $805-816$.

Plafker, George, Hudson, Travis, Rubin, Meyer, and Dixon, K. L., 1982, Holocene marine terraces and uplift history in the Yakataga seismic gap near Icy Cape, Alaska, 'in the United States Geological Survey in Alaska: Accomplishments during 1980: U.S. Geological Survey Circular 844, p. 111-115.

Plafker, George, and Miller, D. J., 1958, Glacial features and surficial deposits of the Malaspina district, Alaska: U.S. Geological Survey Miscellaneous Geology: Investigations Map I-271, scale 1:125,000.

Plafker, G., and Rubin, M., 1967, Vertical tectonic displacements in southcentral Alaska during and prior to the great 1964 earthquake: Journal of Geosciences, Osaka City University, p. 53-72. 
Plafker, George, and Rubin, Meyer, 1978, Uplift history and earthquake recurrence as deduced from marine terraces on Middleton Island, Alaska: U.S. Geological Survey Open-File Report 78-943, p. 687-721.

Plafker, George, Winkler, G., Coonrad, w., Claypool, George, 1980, Preliminary geology of the continental slope adjacent to OCS Lease sale 55, Eastern Gulf of Alaska; Petroleum Resource Implications: U.S. Geological Survey Open-File Report 80-1089, 72 p.

Plafker, George, Winkler, G. R., Hunt, S. J., Bartsch-Winkler, Susan, Coonrad, W. L., and quinterno, Paula, 1978c, Outcrop samples from the continental slope in the eastern Gulf of Alaska: U.S. Geological Survey Circular 772-B, p. B97-99.

Posey, C. J., 1971, Protection of offshore structures against underscour: Journal of the Hydraulics Division: American Society of Civil Engineers, No HY7, Proceedings Paper 8230, p. 1011-1016.

Powers, H. A., 1958, Alaska Peninsula - Aleutian Islands, in Williams, H. (ed.), Landscapes of Alaska: University of California Press, p. 61-75.

Pulpan, H., and Kienle, J., 1979, Western Gulf of Alaska seismic risk: Proceedings of the 11th Offshore Technology Conference, paper 3612 , p. 2209-2218.

Rappeport, M. L., 1981, Studies of tidally-dominated shallow marine bedforms, lower Cook Trough, Cook Inlet, Alaska: Unpublished Ph.D. Thesis, Stanford University, Stanford, California, 323 p.

Rau, w. W., Plafker, George, and winkler, G. R., 1977, Preliminary foraminiferal biostratigraphy and correlation of selected stratigraphic sections and wells in the Gulf of Alaska Tertiary Province: U.S. Geological Survey Open-File Report 77-747, 54 p.

Reimnitz, Erk, 1966, Late Quaternary history and sedimentation of the Copper River delta and vicinity, Alaska: California University, San Diego, Ph.D. thesis (unpub), $160 \mathrm{p}$.

Reimnitz, Erk, 1972, Effects in the Copper River Delta, 'ín the Great Alaska earthquake of 1964: Oceanography and coastal enqineering: Washington, D.C., National Academy of Sciences, p. 290-302.

Reimnitz, Erk, and Carlson, P. R., 1975, Circulation of nearshore surface water in the Gulf of Alaska, in Carlson, P. R., Conomos, R. J., Janda, R. J., and Peterson, D. H., Principal sources and dispersal patterns of suspended particulate matter in nearshore surface waters of the northeast Pacific Ocean: Earth Resources Technology Satellite final report, National Technical Information Service, E75-10266, 145 p.

Rogers, J. F., 1977, Implications of plate tectonics for offshore Gulf of Alaska petroleum exploration: Proceedings, 9th Annual Offshore Technology Conference, p. 11-16. 
Royer, T. C., 1975, Seasonal variations of waters in the northern Gulf of Alaska: Deep Sea Research, v. 22, p. 403-416.

Sangrey, D. A., Clukely, E. C., and Molnia, B. F., 1979, Geotechnical engineering analysis of underconsolidated sediments from Alaska coastal embayments: Proceedings, 11th Offshore Technology Conference, v. 1, p. $677-682$.

Seed, H. B., Murarka, R., Lysmer, J. and Idriss, I. M., 1975, Relationships between maximum acceleration, maximum velocity, distance from source and local site conditions for moderately strong earthquakes: University of California, Earthquake Engineering Research Center, EERC Report No 75-17, Berkeley, California.

Sharma, G. D., and Burell, D. C., 1970, Sedimentary environment and sediments of Cook Inlet, Alaska: American Association of Petroleum Geologists Bulletin, v. 54, p. 647-654.

Stephens, C. D., Lahr, J. C., Fogleman, K. A., and Horner, R. B., 1980, The St. Elias, Alaska, earthquake of February 28, 1979, Regional recording of aftershocks and short-term, pre-earthquake seismicity: Bulletin of the Seismological Society of America, v. 70, n. 5, p. 1607-1634.

Stonely, Robert, 1967, The structural development of the Gulf of Alaska sedimentary province in southern Alaska: Quarterly Journal of the Geological Society of London, v. 123, p. 25-57.

Stover, C. W., Reagor, B. G., and Wetmiller, R. J., 1980, Intensities and isoseismal map for the St. Elias earthquake of February 28, 1979: Bulletin of the Seismological Society of America, v. 70, n. 5, p. 1635-1650.

Sykes, L. R., 1971, Aftershock zones of great earthquakes, seismicity gaps, and earthquake prediction for Alaska and the Aleutians: Journal of Geophysical Research, v. 75, p. 8021-8041.

Sykes, L. R., Kisslinger, J. B., House, L., Davies, J. N., and Jacob, K. H., 1980, Rupture zones of great earthquakes in the Alaska-Aleutian arc, 1784-1980: Science, v. 210, p. 1343-1345.

Taylor, P. T., and O'Neill, N. J., 1974, Results of an aeromagnetic survey in the Gulf of Alaska: Journal of Geophysical Research, v. 79, no. 5, p. 719-723.

Tissot, B. P., and Welte, D. H., 1978, Petroleum formation and occurrence: New York, Springer-Verlag, 538 p.

Toucher, D., 1960, The Alaska earthquake of July 10, 1958 -- movement of the Fairweather fault and field investigation of southern epicentral region: Seismological Society of America Bulletin, v. 50, p. 267-292. 


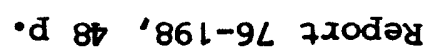

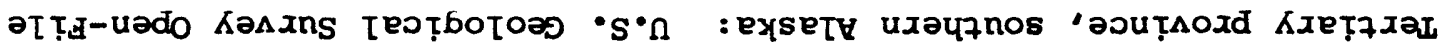

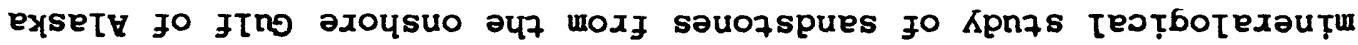

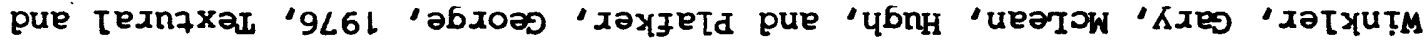

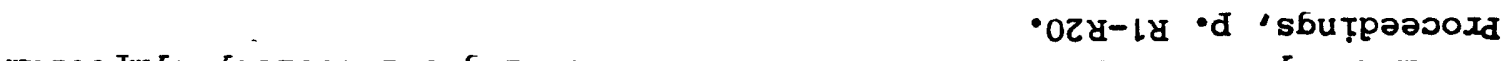

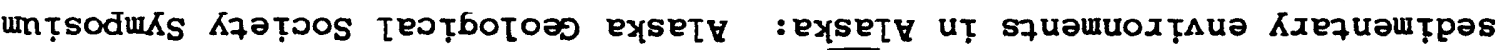

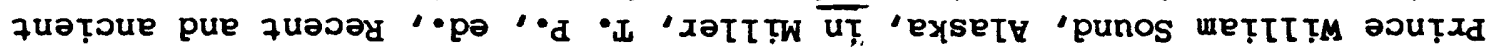

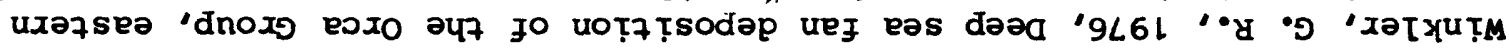

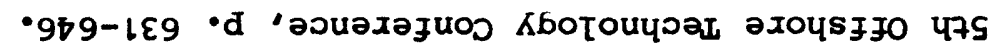

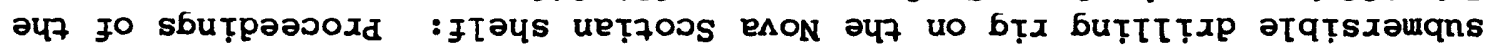

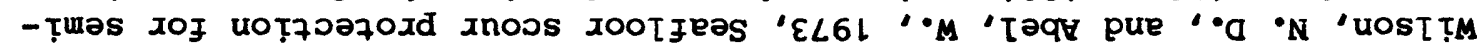

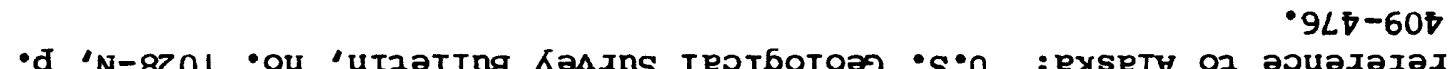

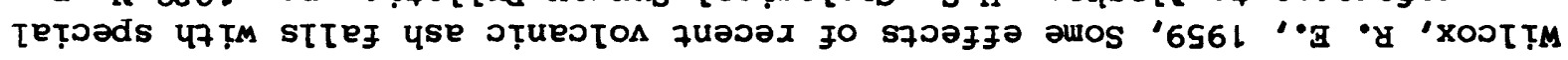

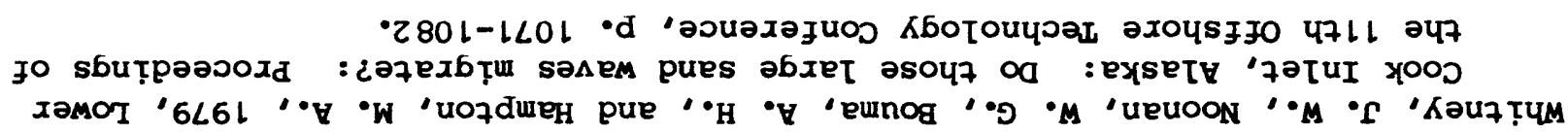

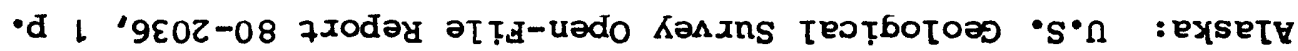

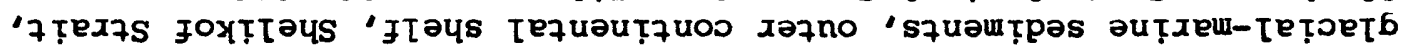

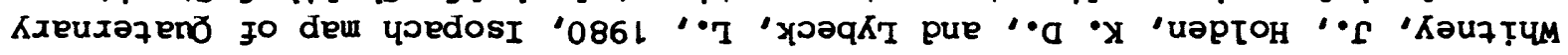

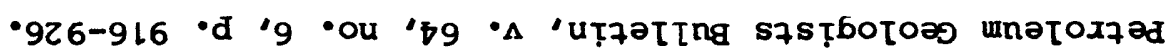

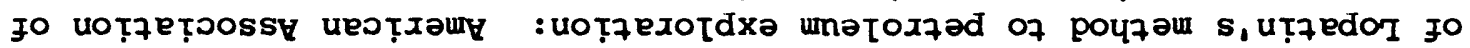

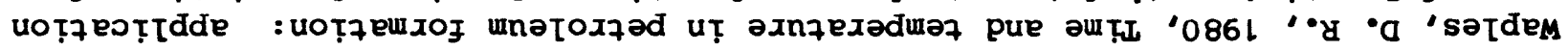

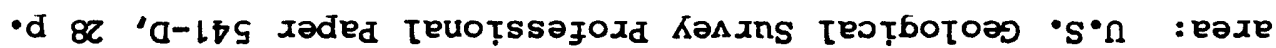
גәшон әч7 uт̣ “

$\cdot 06 z-\varepsilon<z \cdot d \cdot 6 z$

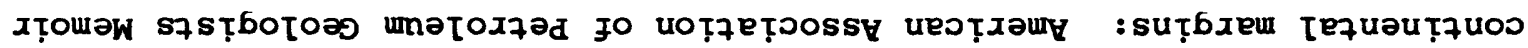

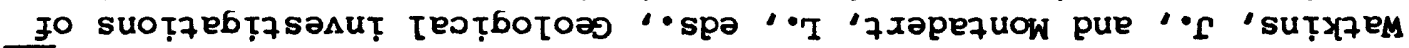

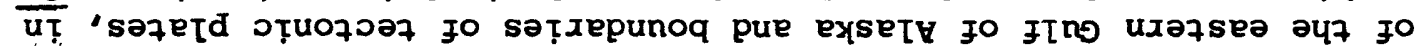

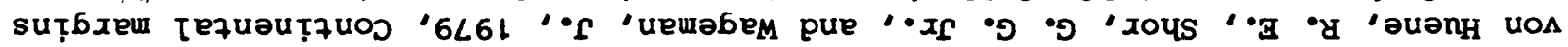

- $799-s L$ 7XOdəy

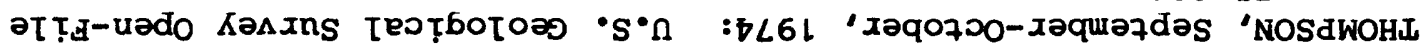

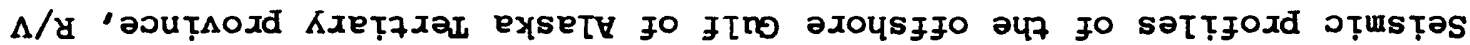

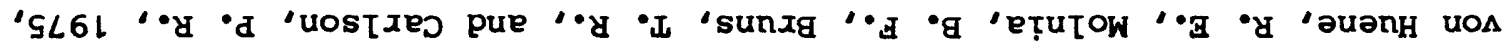

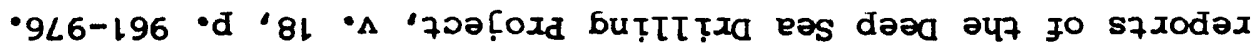

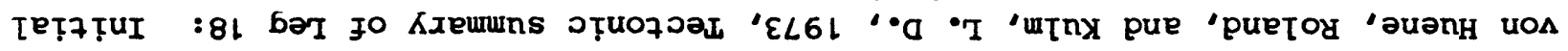

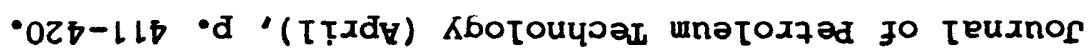

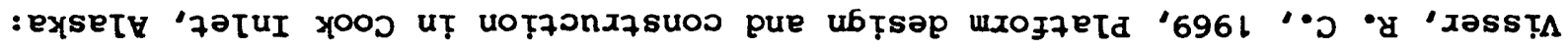

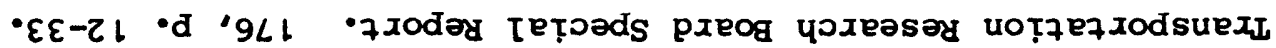

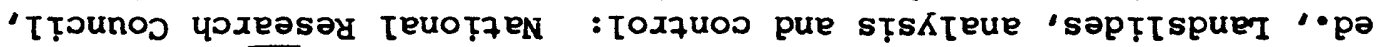

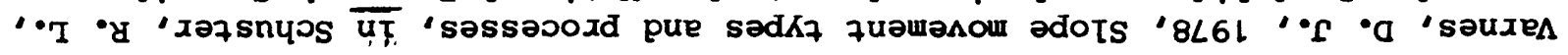

